FLAVIO ALVES POZZI

\title{
INDICADORES DE POSIÇÃO ECONÔMICA PARA SISTEMAS COM UNIDADE CENTRAL ADMINISTRATIVA E VÁRIAS UNIDADES DE NEGÓCIOS
}

Tese apresentada à Escola Politécnica da Universidade de São Paulo para obtenção do Título de Doutor em Engenharia. 
FLAVIO ALVES POZZI

\section{INDICADORES DE POSIÇÃO ECONÔMICA PARA SISTEMAS COM UNIDADE CENTRAL ADMINISTRATIVA E VÁRIAS UNIDADES DE NEGÓCIOS}

Tese apresentada à Escola Politécnica da Universidade de São Paulo para obtenção do Título de Doutor em Engenharia.

Área de Concentração:

Engenharia de Produção

Orientador:

Prof. Dr. Israel Brunstein

São Paulo 
Este exemplar foi revisado e alterado em relação à versão original, sob responsabilidade única do autor e com a anuência de seu orientador.

São Paulo, de outubro de 2006.

Assinatura do autor

Assinatura do orientador

FICHA CATALOGRÁFICA

Pozzi, Flavio Alves

Indicadores de posição econômica para sistemas com unidade central administrativa e várias unidades de negócios / F.A. Pozzi. -- ed.rev. -- São Paulo, 2006. 170 p.

Tese (Doutorado) - Escola Politécnica da Universidade de São Paulo. Departamento de Engenharia de Produção.

1. Indicadores econômicos 2. Custeio direto 3. Custo econômico I. Universidade de São Paulo. Escola Politécnica. Departamento de Engenharia de Produção Il. t. 
Às mulheres de minha vida: minha esposa Susana e minhas filhas Beatriz e Clara. 
Agradeço primeiramente a Deus. Agradeço a todas as pessoas que contribuíram direta ou indiretamente para que este trabalho fosse realizado e também para que eu me desenvolvesse e chegasse ao atual estágio, em especial:

- a minha família pelo apoio e compreensão durante as longas horas de ausência;

- ao Prof. Dr. Israel Brunstein pela oportunidade, por ter apresentado e confiado o tema desta Tese, pelas orientações e diretrizes seguras, por ter acreditado em meu trabalho e pela honra que me deu em poder trabalhar com uma referência viva da Engenharia de Produção deste país;

- Agradeço especialmente a todos meus mestres. Cada um a seu tempo e a seu modo, me inspirou a querer sempre saber mais para transmitir o melhor e ser capaz de ajudar quem de mim precisasse. Muitos nem sabem quanto foram importantes, porque para eles, eu era apenas um dos alunos. Entretanto, muito mais que aluno fui discípulo de Gibson Barcelos Reggiani, Leonardo Junqueira Lustosa, Álvaro Abreu, Denílson Carvalho, José Soares Coutinho Filho, Francisco Carlos Sardo e Israel Brunstein;

- ao professor Michitoshi Oishi pelo incentivo e apoio para que este sonho fosse realizado;

- aos professores José Roberto Ferreira Savóia e Reinaldo Pacheco da Costa pelas contribuições no final do projeto;

- ao amigo Eurycibiades Barra Rosa pelo companheirismo e ensinamentos desde o início do Doutorado;

- a minha irmã Jocélia Pozzi Pimentel pelas longas horas de revisão ortográfica;

- e por tudo, agradeço a Antonio Pozzi (meu pai) e Maria Alves Pozzi (minha mãe) modelos de empenho e luta; exemplos que conduziram meu crescimento moral e intelectual. 


\section{RESUMO}

O trabalho apresenta um modelo econômico para auxílio à tomada de decisão em nível tático e estratégico, podendo ser aplicado tanto a empresas do setor industrial como de serviços que possuem uma sede administrativa com várias unidades de negócios dispersas ou não geograficamente.

O modelo pode retratar a situação passada, presente e futura da empresa, mostrando claramente como os valores econômicos foram obtidos e como se compuseram para formar o resultado final. Os resultados podem ser utilizados para a simulação de possíveis alterações, avaliando os resultados através dos cenários propostos podendo servir como referencial para o planejamento estratégico.

Para tanto, este trabalho propõe a utilização de medidas de posição econômica no intuito de medir a situação econômica de cada Produto/Unidade Estratégica de Negócio através da Margem de Segurança, do Grau de Alavancagem Operacional, do Grau de Alavancagem Operacional Combinado e da Análise de Equilíbrio da empresa, tendo como conseqüência, a situação econômica da sede administrativa medida através das contribuições advindas de cada Unidade Estratégica de Negócio.

O cálculo dos indicadores de posição econômica torna-se muito importante no âmbito da quantificação da posição econômica da empresa, medindo o impacto dos subsistemas em sua situação econômica através da análise das posições econômicas relevantes e diferenciadas. Os indicadores podem ser comparados com indicadores de outras empresas do mesmo setor, com outras Unidades Estratégicas de Negócios da mesma empresa, com dados passados da mesma Unidade Estratégica de Negócio etc. 


\begin{abstract}
This work presents an economic model towards helping take a tactical and strategic decision which can be applied either to the industrial or service sector companies that have an administrative headquarter with various business units geographically spread out or not.
\end{abstract}

The model can portray the company's past, present or future situation, clearly showing how the economic figures were obtained and how they have come together to form the final result. The results can be used to simulate possible alterations, evaluating the results through the proposed scenarios which can serve as a reference for the strategic planning.

To that effect, this work proposes the use of measures of economic position in order to measure the economic situation of each Product/Business Units Through the Security Margin, the Degree Operational Leverage, the Combined Degree Operational Leverage and the Analysis of the Company's Equilibrium, having, as a consequence, the administrative headquarter's economic situation measured through the contributions obtained from each Business Units.

The calculation of the economic position indicators becomes very important in the quantification range of the company's economic position, measuring the impact of the subsystems in an economic situation through the analysis of the relevant and differentiated economic positions. The indicators can be compared to other companies' indicators of the same sector, to other Business Units of the same company, to the past data of the same Business Units, etc. 
1. INTRODUÇÃ

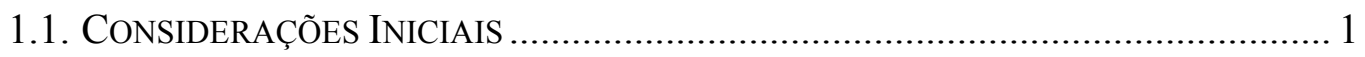

1.2. O PROJETO DE PESQUISA …..................................................................... 7

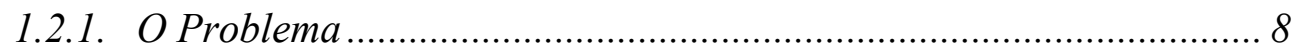

1.2.2. Objetivo Geral e Especifico ....................................................... 9

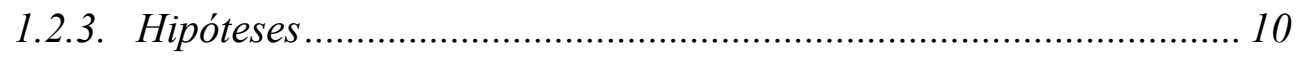

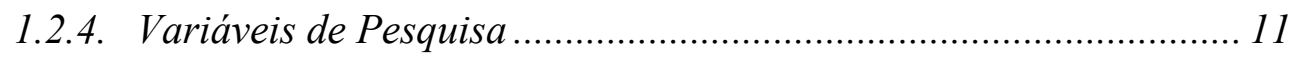

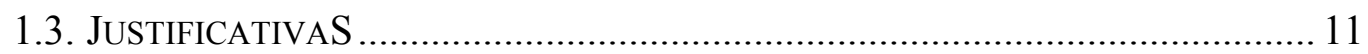

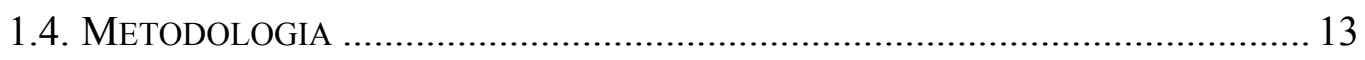

1.4.1. Método de Abordagem ............................................................... 14

1.4.2. Método de Procedimento ............................................................ 15

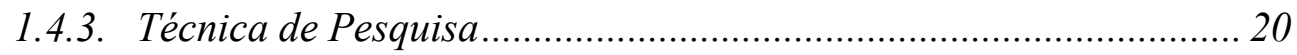

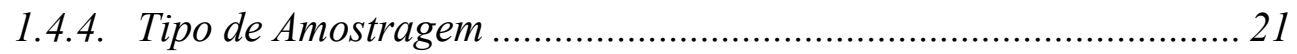

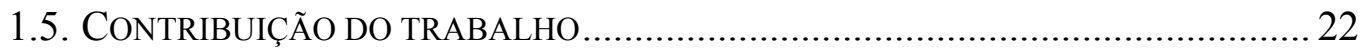

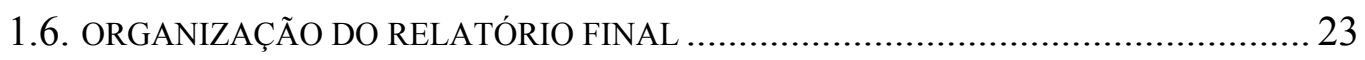

2. DESCRIÇÃO DO SISTEMA ADMINISTRATIVO .................................... 25

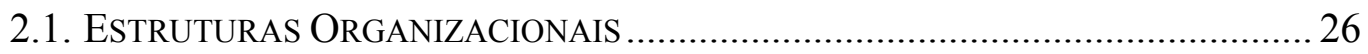

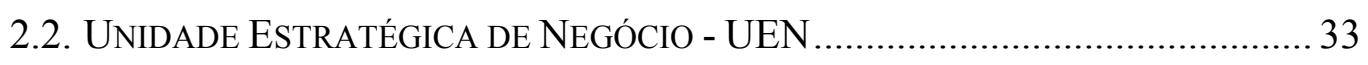

2.3. Para Que Serve a Unidade Estratégica de Negócios? ........................ 38

2.3.1. Benefícios da Adoção do Conceito de UEN...................................... 39

2.4. FATORES CRÍTICOS DE SUCESSO ................................................................ 41

2.5. Definição da Estrutura Organizacional ObJeto do Trabalho......... 42

2.5.1. Nivel de Abrangência da Empresa ............................................... 43

2.5.2. Nivel de Abrangência da UEN - Unidade Estratégica de Negócio. 43

2.5.3. Nivel de Abrangência da Corporação ............................................ 43

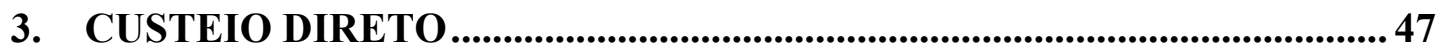

3.1. Custeio Por AbSORÇão e o CuSteio Direto............................................ 49 
3.2. Vantagens E Desvantagens do Custeio Direto.....

3.3. REPRESENTAÇÃo ESQUEMÁTICA do Modelo ECONÔMICO DA EMPRESA .... 55

3.4. Algumas ConsideraÇões a Respeito do Custeio Direto 60

3.5. FORMULAÇÃO MATEMÁTICA PARA O MODELO ECONÔMICO PROPOSTO 61

3.6. EXEMPLO NUMÉRICO 66

4. INDICADORES DE POSIÇÃO ECONÔMICA.......................................... 70

4.1. Ponto de Equilíbrio (Break-Even Point) ............................................ 71

4.1.1. Análise de Ponto de Equilíbrio Considerando Um Produto............ 73

4.1.2. Análise de Ponto de Equilibrio Para Dois Produtos...................... 79

4.1.3. Pontos de Equilíbrio por Produto................................................. 81

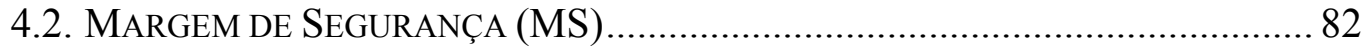

4.2.1. Cálculo do Ponto de Equilibrio Através da Margem de Segurança 86

4.3. Grau de Alavancagem Operacional (GAO) ........................................ 86

4.3.1. Margem de Segurança x Grau de Alavancagem Operacional ........89 4.4. AnÁlise de SENSibilidade PARA Alterações no Custo-Volume-LuCro

5. MODELAGEM ECONÔMICA DE UM SISTEMA COM UMA UNIDADE CENTRAL ADMINISTRATIVA E VÁRIAS UNIDADES DE NEGÓCIOS 95

5.1. IDENTIFICAÇÃO DAS VARIÁVEIS INDEPENDENTES .............................96

5.1.1. Orçamento: Alocação de Recursos ................................................ 97

5.1.2. Orçamento x Identificação das Variáveis Independentes.............. 101

5.2. CÁLCULO DOS INDICADORES DE POSIÇÃO ECONÔMICA A PARTIR DA

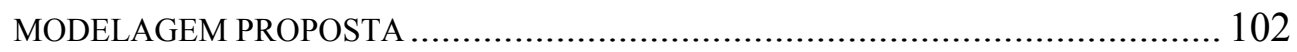

5.2.1. Grau de Alavancagem Operacional - GAO ............................. 102

5.2.2. Grau de Alavancagem Operacional Combinado - GAOC............ 105

5.2.3. Margem de Segurança-MS ...................................................... 108

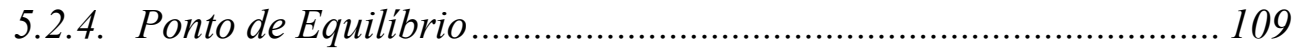

5.3. CONSIDERAÇÕES SOBRE A ANÁLISE DO GAO E DO GAOC ........................... 111

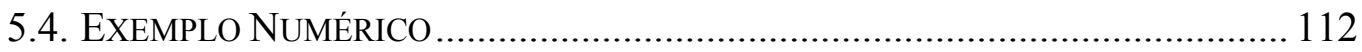


5.4.1. Resolução Inicial. 113

5.4.2. Análise dos Resultados da UEN-1 ............................................. 113

5.4.3. Análise dos Resultados da UEN-2 ….......................................... 118

5.4.4. Análise dos Resultados da Sede Administrativa ........................... 124

\section{APLICAÇÃO DA METODOLOGIA EM UMA INSTITUIÇÃO DE} ENSINO SUPERIOR....................................................................................... 127

6.1. CALCULO DOS INDICADORES DE POSIÇÃO ECONÔMICA ................................ 142

6.1.1. GAO dos Produtos por Mercado ................................................. 142

6.1.2. GAOC dos Produtos por Mercado................................................ 149

6.1.3. GAO e GAOC das UEN's ............................................................ 156

6.1.4. Margem de Segurança das UENS............................................. 158

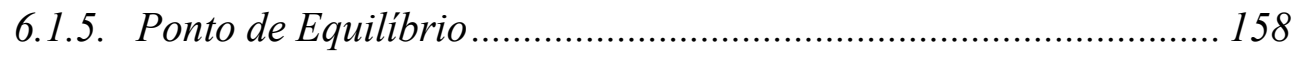

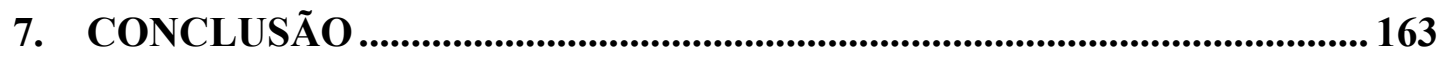

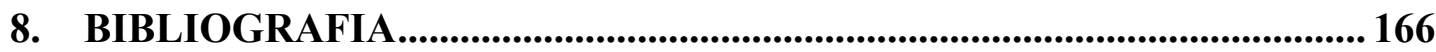




\section{LISTA DE FIGURAS}

Figura 2.1 - Os cinco tipos de estruturas organizacionais

Figura 2.2 - AEN versus UEN 35

Figura 2.3 - Dimensões Importantes de Posição Competitiva 41

Figura 2.4 - Estrutura com uma unidade central e várias unidades de negócios 45

Figura 3.1 - Apuração do resultado do período 55

Figura 3.2 - Representação Esquemática do Modelo Econômico da Empresa 59

Figura 3.3 - Resolução do Exemplo-3.1, utilizando Representação Esquemática do Modelo Econômico. 68

Figura 4.1 - Ponto de Equilíbrio 75

Figura 4.2 - Ponto de Equilíbrio - análise da Margem de Contribuição 76

Figura 4.3 - Ponto de Equilíbrio considerando a tributação. 79

Figura 4.4 - Reta de equilíbrio para dois produtos 80

Figura 4.5 - Reta de equilíbrio para dois produtos - Análise de margem de Segurança 82

Figura 4.6 - Análise de Margem de Segurança 83

Figura 4.7 - Variação do GAO e da MS 90

Figura 4.8 - Efeitos de alterações de políticas diversas na relação lucro-volume.... 94

Figura 5.1 - Modelo de uma Estrutura Organizacional com Sede Administrativa e Várias Unidades de Negócios 96 
Figura 5.2 - Orçamento Mestre

Figura 5.3 - Possíveis sinais para o GAO e o GAOC

Figura 5.4 - Resultado da UEN-1 utilizando Representação Esquemática do Modelo Econômico.

Figura 5.5 - Resultado da UEN-2 utilizando Representação Esquemática do Modelo Econômico.

Figura 5.6 - Resolução da Sede Administrativa utilizando Representação

Esquemática do Modelo Econômico.

Figura 6.1 - Representação da Estrutura da Universidade conforme Modelo Apresentado.

Figura 6.2 - Resultado da UEN-1 utilizando a Representação Esquemática do Modelo Econômico. 136

Figura 6.3 - Resultado da UEN-2 utilizando a Representação Esquemática do Modelo Econômico

Figura 6.4 - Resultado da UEN-3 utilizando a Representação Esquemática do Modelo Econômico

Figura 6.5 - Resultado da UEN-4 utilizando a Representação Esquemática do Modelo Econômico

Figura 6.6 - Resultado da UEN-5 utilizando a Representação Esquemática do Modelo Econômico.

Figura 6.7 - Resolução da Sede Administrativa utilizando Representação Esquemática do Modelo Econômico

Figura 6.8 - Análise gráfica do GAO dos Produtos da UEN-1 143

Figura 6.9 - Análise gráfica do GAO dos Produtos da UEN-2 
Figura 6.10 - Análise gráfica do GAO dos Produtos da UEN-3

Figura 6.11 - Análise gráfica do GAO dos Produtos da UEN-4

Figura 6.12 - Análise gráfica do GAO dos Produtos da UEN-5 ........................... 148

Figura 6.13 - Análise gráfica do GAOC dos Produtos da UEN-1 ........................ 150

Figura 6.14 - Análise gráfica do GAOC dos Produtos da UEN-2 ….................... 151

Figura 6.15 - Análise gráfica do GAOC dos Produtos da UEN-3 _....................... 152

Figura 6.16 - Análise gráfica do GAOC dos Produtos da UEN-4 ........................ 154

Figura 6.17 - Análise gráfica do GAOC dos Produtos da UEN-5 …..................... 155 


\section{LISTA DE TABELAS}

Tabela 3.1 - Dados referentes ao produto 1 66

Tabela 3.2 - Dados referentes ao produto 2 66

Tabela 3.3 - Cálculo da Margem de Contribuição Untaria dos produtos para cada mercado

Tabela 5.1 - Dados referentes aos produtos 1 e 2 da UEN-1

Tabela 5.2 - Dados referentes aos produtos 1, 2 e 3 da UEN-2.

Tabela 5.3 - Cálculo da Margem de Contribuição unitária dos produtos para cada mercado da UEN-1

Tabela 5.4 - Cálculo da Margem de Contribuição unitária dos produtos para cada mercado da UEN-2

Tabela 6.1 - Variáveis Independentes dos Cursos da UEN-1

Tabela 6.2 - Variáveis Independentes dos Cursos da UEN-2.

Tabela 6.3 - Variáveis Independentes dos Cursos da UEN-3.

Tabela 6.4 - Variáveis Independentes dos Cursos da UEN-4.

Tabela 6.5 - Variáveis Independentes dos Cursos da UEN-5.

Tabela 6.6 - Custos e Despesas Fixas das UENs e da Sede Administrativa

Tabela 6.7 - Comparação da Receita Bruta x MSBC de cada UEN

Tabela 6.8 - GAO dos Produtos da UEN-1 por Mercado 142

Tabela 6.9 - GAO dos Produtos da UEN-2 por Mercado 144 
Tabela 6.10 - GAO dos Produtos da UEN-3 por Mercado

Tabela 6.11 - GAO dos Produtos da UEN-4 por Mercado 146

Tabela 6.12 - GAO dos Produtos da UEN-5 por Mercado 148

Tabela 6.13 - GAOC dos Produtos da UEN-1 por Mercado 149

Tabela 6.14 - GAOC dos Produtos da UEN-2 por Mercado 151

Tabela 6.15 - GAOC dos Produtos da UEN-3 por Mercado 152

Tabela 6.16 - GAOC dos Produtos da UEN-4 por Mercado 153

Tabela 6.17 - GAOC dos Produtos da UEN-4 por Mercado 155

Tabela 6.18 - GAO e GAOC das UEN's. 156

Tabela 6.19 - MS das UEN's 158

Tabela 6.20 - Ponto de Equilíbrio x Quantidade Vendia dos Produtos da UEN-1 nos Respectivos Mercados 159

Tabela 6.21 - Ponto de Equilíbrio x Quantidade Vendia dos Produtos da UEN-2 nos Respectivos Mercados 160

Tabela 6.22 - Ponto de Equilíbrio x Quantidade Vendia dos Produtos da UEN-3 nos Respectivos Mercados 160

Tabela 6.23 - Ponto de Equilíbrio x Quantidade Vendia dos Produtos da UEN-4 nos Respectivos Mercados 161

Tabela 6.24 - Ponto de Equilíbrio x Quantidade Vendia dos Produtos da UEN-5 nos Respectivos Mercados 161

Tabela 6.25 - Ponto de Equilíbrio das UEN's 162 
AEN - Área Estratégica de Negócio

CDF - Custos e Despesas Fixas

CF - Custo Fixo

CIF - Custos Indiretos de Fabricação

$\mathrm{CV}$ - Custo Variável

DO - Desenvolvimento Organizacional

DPF - Despesas Proporcionais ao Faturamento

EVA - Valor Econômico Adicionado

GAO - Grau de Alavancagem Operacional

GAOC - Grau de Alavancagem Operacional Combinado

GE - General Elétric

MBC - Margem Bruta de Contribuição

MC - Margem de Contribuição

MO - Mão-de-Obra

MS - Margem de Segurança

MSBC - Margem Semi-Bruta de Contribuição

P\&D - Pesquisa e Desenvolvimento

PE - Ponto de Equilíbrio

PV - Preço de Venda

ROI - Retorno Sobre o Investimento

ROS - Retorno Sobre Vendas

UEN - Unidade Estratégica de Negócio 


\section{LISTA DE SÍMBOLOS}

$C D F-$ Custos e Despesas Fixas

$C D F_{i}-$ Custos e despesas fixas próprio do produto $i$

$C D F_{i j}$ - Custos e despesas fixas próprio do produto $i$ no mercado $j$

$C D F_{k}$ - Custos e despesas fixas comuns da UEN $k$ (custo de período)

$C D F_{\text {sede }}$ - Custos e despesas fixas comuns da sede administrativa

$C V_{i j}$ - Custo variável total do produto $i$ no mercado $j$

$C V M_{i}$ - Custo variável médio unitário do produto $i$

$D P F_{i j}$ - Despesas proporcionais ao faturamento do produto i no mercado $j$

$C T$ - Custo Total

$C V_{i}$ - Custo Variável do Produto $i$

$G A O$ - Grau de Alavancagem Operacional

GAOC - Grau de Alavancagem Operacional Combinado

$G A O_{\left(P_{i} / U E N_{k}\right)}$ - Grau de Alavancagem Operacional do produto-i em relação a $U E N_{k}$

$G A O_{U E N_{k}}-$ GAO de uma UEN específica

$G A O_{\left(P_{i j} / U E N_{k}\right)}-\mathrm{GAO}$ do Produto $i$ no mercado $j$ em relação a $\mathrm{UEN}_{k}$

$\operatorname{GAOC}_{\left(U E N_{k}\right)_{S E D E}}-$ GAOC da UEN $k$ incidente na Sede Administrativa

$\operatorname{GAOC}_{\left(P_{i j} / U E N_{k}\right)_{S E D E}}-$ GAOC do Produto $i$, no mercado $j$, da UEN $k$ incidente na Sede Administrativa

$\operatorname{GAOC}_{\left(P_{i} / U E N_{k}\right)_{S E D E}}-$ GAOC do Produto $i$ da UEN $k$ incidente na Sede Administrativa

$G A O C_{S E D E}-$ GAOC da Sede Administrativa

$i$ - representa o produto

$I R$ - Imposto de Renda (unidades monetárias)

$I r$ - imposto de renda em valores percentuais

$j$ - representa o mercado onde o produto é vendido

$k$ - representa a Unidade Estratégica de Negócio considerada

$m$ - número total de produtos i vendidos

$L B$ - Lucro Bruto 
$L L$ - Lucro Líquido

$M S B C_{i}-$ Margem bruta de contribuição do produto $i$ em todos os mercados

$M S B C_{\text {Total- } i}$ - Margem bruta de contribuição total do produto

$M B C_{i j}$ - Margem bruta de contribuição do produto $i$ no mercado $j$

$M B C T_{k}$ - Margem bruta de contribuição total da UEN $k$

$M B C u_{i j}$ - Margem bruta de contribuição unitária do produto $i$ no mercado $j$

$M C$ - Margem de Contribuição Total

$M C u_{i}$ - Margem de Contribuição Unitária do Produto $i$

$M S$ - Margem de Segurança

$M S B C_{i}$ - Margem semi-bruta de contribuição do produto $i$

$M S B C_{i j}$ - Margem semi-bruta de contribuição do produto $i$ no mercado $j$

$\operatorname{MSBCT}_{k}$ - Margem semi-bruta de contribuição total da UEN $k$

$M S_{U E N_{k}}$ - Margem de Segurança da UEN $k$

$M S_{S E D E}$ - Margem de Segurança da Sede Administrativa

$Q e_{U E N-k}$ - Ponto de Equilíbrio Global da UEN $k$

$n$ - número total de diferentes mercados em que o produto i é vendido

$p$ - número total de Unidade Estratégicas de Negócios de uma Empresa

$P_{i}$ - Preço de Venda do Produto $i$

$P V_{i j}$ - Preço de venda do produto $i$ no mercado $j$

$P V L_{i j}$ - Preço de venda líquido do produto $i$ no mercado $j$

$Q_{i}$ - Quantidade Produzida do Produto $i$

$Q e_{\left(P_{i j} / U E N_{K}\right)}$ - Ponto de Equilíbrio do Produto $i$ no mercado $j$ da UEN $k$

$Q e_{i}-$ Quantidade de Equilíbrio

$Q_{i j}$ - Quantidade faturada do produto $i$ no mercado $j$

$R$ - Receita

$R B_{i j}$ - Receita bruta do produto $i$ no mercado $j$

$R E S_{k}$ - Resultado da UEN $k$ (lucro antes do imposto de renda)

$R E S_{\text {sede }}$ - Resultado da sede administrativa (lucro antes do imposto de renda)

$R L_{i j}$ - Receita líquida do produto $i$ no mercado $j$

$R L T_{k}-$ Receita líquida total da UEN $k$ 
$R L T_{i}$ - Receita líquida total do produto $i$ 


\section{INTRODUÇÃ̃O}

O presente título discute os aspectos relevantes do tema do projeto de pesquisa. Justifica a importância do assunto e apresenta o problema de pesquisa e os objetivos geral e específico do trabalho. $\mathrm{O}$ tema e a sua delimitação estão aqui definidos, assim como também o objeto de pesquisa, as hipóteses, a metodologia de pesquisa utilizada e a organização estrutural do relatório final.

\subsection{CONSIDERAÇÕES INICIAIS}

O registro contábil das transações financeiras data de muitos anos, quando era utilizado pelos egípcios, fenícios e sumérios para facilitar as transações comerciais. Alguns séculos mais tarde, na época das explorações, as atividades das empresas eram medidas e monitoradas pelos livros-caixa de partidas dobradas. A Revolução Industrial, no século XIX, fez nascer grandes empresas nos setores têxtil, ferroviário, siderúrgico, industrial e varejista. As inovações desenvolvidas por elas na medição do desempenho financeiro exerceram um papel vital no seu crescimento bemsucedido, utilizando-se de instrumentos de medição tais como o retorno sobre o investimento, o orçamento operacional, o orçamento de caixa até o atual Valor Econômico Adicionado (EVA), fundamentais para o grande sucesso de empresas fundadas no século XX.

Após a Segunda Guerra Mundial, a tendência de diversificação gerou a necessidade de relatórios e medidas de desempenho das unidades de negócios, prática muito utilizada por empresas diversificadas como a General Eletric, que se tornou famosa pelos rigorosos relatórios e controles financeiros desenvolvidos.

Segundo KAPLAN e NOTON (1997), o aspecto financeiro do desempenho das unidades de negócios atingiu um ponto máximo de sofisticação. Contudo, muitos analistas vêm criticando o uso extenso, e até exclusivo, das medidas financeiras nos negócios. Na prática, a ênfase excessiva na obtenção e manutenção de resultados financeiros de curto prazo pode levar as empresas a investirem demais em soluções 
rápidas e superficiais em detrimento da criação de valor no longo prazo. As medidas financeiras são inadequadas para orientar e avaliar a trajetória organizacional em ambientes competitivos, as medidas financeiras contam parte, mas não toda a história das ações passadas e não fornecem orientações adequadas para as ações que devem ser realizadas hoje e amanhã para criar valor futuro.

O advento da globalização e da era da informação nas últimas décadas do século XX tornou obsoletas muitas das premissas fundamentais da concorrência industrial. As empresas não conseguem mais obter vantagens competitivas sustentáveis apenas com a rápida alocação de novas tecnologias e com a excelência da gestão eficaz dos ativos e passivos financeiros, tornando o impacto ainda mais revolucionário para as empresas prestadoras de serviços acostumadas à décadas com um confortável ambiente não-competitivo.

Nesse contexto, as fronteiras nacionais deixaram de ser um obstáculo à concorrência de empresas estrangeiras mais eficientes e ágeis, fazendo com que as empresas brasileiras concorram com as melhores empresas do mundo em seu ramo de atividade. Os investimentos necessários para o lançamento de novos produtos e serviços podem ser grandes e exigir a busca de clientes no mundo inteiro para gerar o retorno adequado, criando a necessidade de uma empresa ter várias unidades de negócios, dispersas ou não geograficamente.

Por outro lado, os ciclos de vida dos produtos continuam diminuindo, sendo que a vantagem competitiva numa geração da vida de um produto não garante a liderança futura. As empresas devem dominar, cada vez mais, a arte de prever as necessidades futuras dos clientes, idealizando produtos e serviços inovadores, incorporando rapidamente novas tecnologias de produto e de produção para dar eficiência aos processos operacionais e de prestação de serviços.

Neste sentido, a empresa deve cercar-se de instrumentos de gestão econômica que possam garantir sua competitividade presente e futura, medindo com uma certa exatidão e/ou direcionando suas ações que envolvam decisões de custo/volume/lucro, buscando manter a longevidade da saúde econômica e financeira da empresa. 
Pode-se dizer que o ambiente da era da informação, tanto para as organizações do setor industrial quanto para as do setor de serviços, exige metodologias de gestão capazes de assegurar o sucesso competitivo e o crescimento sustentável. Por outro lado, em um processo de gestão voltado para a lucratividade, é necessário um monitoramento de indicadores de eficiência que possam mostrar a situação da empresa e, principalmente, a situação interna dos processos, de tal forma que o administrador possa verificar e controlar o lucro e a saúde financeira e econômica da empresa, avaliando o efeito de melhorias internas ao longo do tempo.

Então, o conhecimento econômico dos processos e dos produtos é uma condição de extrema importância para que a empresa possa se manter competitiva. Para que isso ocorra, torna-se necessário rever continuamente suas formas de organização, desenvolvendo projetos de reestruturação com o objetivo de racionalizar processos que não agreguem valor aos produtos, buscando assim um grau máximo de competitividade. Essa busca envolve o comprometimento com um contínuo e completo aperfeiçoamento de seus produtos, seus processos e seus colaboradores.

Segundo COLLINS e PORRAS (1995, apud SHIRAISHI, 2003), a lucratividade é uma condição necessária para a existência e um meio de se atingir objetivos mais importantes, mas não é o objetivo em si para muitas das empresas visionárias. Os lucros são o que o oxigênio, a comida, a água e o sangue representam para o corpo; eles não são o sentido da vida, mas sem eles não há vida.

KAPLAN e NORTON (1997) dizem que todos os novos programas, iniciativas e processos de gerenciamento de mudanças das empresas da era da informação estão sendo implementados num ambiente regido por relatórios financeiros trimestrais e anuais. O processo de gestão através de relatórios financeiros continua atrelado a um modelo contábil desenvolvido há séculos para um ambiente de transações isoladas entre entidades independentes. O modelo da contabilidade financeira ainda está sendo utilizado por empresas da era da informação, ao mesmo tempo em que tentam construir ativos e capacidades internas e criar relações e alianças estratégicas com entidades externas. 
Tradicionalmente, orientando-se nas estratégias formuladas pela alta cúpula, as atuações dos profissionais não-financeiros, na grande maioria dos casos se voltaram para os seguintes objetivos: desenvolver produtos e serviços que representem um valor superior para os clientes; traduzir as especificações em produtos e serviços impecáveis e a custos adequados; e manter uma base de inovação que garanta a liderança.

Com essa visão, muitas organizações formularam grandes estratégias, implementaram teorias, filosofias, sistemas, técnicas e ferramentas avançadas e complexas, conquistaram mercados, reduziram as falhas internas e externas e chegaram a ser vistas como "empresas de excelência".

KAPLAN e NOTON (1997), afirma que no esforço de se tornarem competitivas no futuro, as organizações estão lançando mão de diversas iniciativas de melhoria:

- Gestão da qualidade total.

- Produção e sistemas de distribuição just-in-time.

- Competição baseada no tempo.

- Produção enxuta/empresa enxuta.

- Criação de organizações focalizadas no cliente.

- Gestão de custos baseados em atividades.

- Empowerment dos funcionários.

- Reengenharia.

O autor diz ainda, que cada um desses programas de melhoria apresenta histórias comprovadas de sucesso, gurus e consultores. Cada um disputa o tempo, a energia e os recursos dos altos executivos. E cada qual promete melhorias excepcionais de desempenho e a geração de valor para as partes interessadas na empresa: acionistas, clientes, fornecedores e funcionários.

A meta desses programas não é a melhoria incremental ou a sobrevivência, mas o desempenho descontínuo, permitindo que a empresa seja bem-sucedida. No entanto, muitos desses programas de melhoria produziram resultados frustrantes; são 
quase sempre iniciativas isoladas, dissociadas da estratégia organizacional, não alcançando resultados financeiros e econômicos específicos.

Nesta mesma linha de raciocínio, na segunda metade do século XX foram criados inúmeros indicadores econômicos e financeiros, embasados em cima de teorias muitas vezes complexas, que em dado momento "viraram febre" nas empresas, com promessas de torná-las mais competitivas e lucrativas, sendo que muitas dessas metodologias geraram bons resultados e outras levaram empresas à falência.

Portanto, investigando as raízes do desenvolvimento da ciência, da tecnologia e da economia devemos examinar cuidadosamente a formação de uma visão do mundo e de uma ciência que pretendem reconceituar a realidade mais como uma máquina do que como um organismo vivo.

Nesse sentido, com o modelo mecanicista do universo, originado no século XVII e com a excessiva ênfase dada ao pensamento linear, foram desenvolvidas nas últimas décadas, teorias e metodologias de gestão que tentam reconceituar a realidade das indústrias mais como uma máquina do que como um organismo vivo.

Para DESCARTES, o universo material era uma máquina, nada além de uma máquina. A natureza funcionava de acordo com leis da mecânica, e tudo no mundo material podia ser explicado em função da organização e do movimento de suas partes. Portanto, em sua tentativa de construir uma ciência natural completa, DESCARTES estendeu sua concepção mecanicista da matéria aos organismos vivos, onde plantas e animais passaram a ser considerados simples máquinas. Esse quadro mecânico da natureza tornou-se o paradigma dominante da ciência no período que se seguiu a DESCARTES. Conforme CAPRA (2002) observou, psicólogos, sociólogos e economistas, ao tentarem ser científicos, sempre se voltaram naturalmente para DESCARTES e para os conceitos básicos da física newtoniana.

No século XX, entretanto, a física passou por várias revoluções conceituais que revelam claramente as limitações da visão de mundo mecanicista e levam a uma visão orgânica, sistêmica. O universo deixou de ser visto como uma máquina 
composta de uma profusão de objetos distintos, para apresentar-se agora como um todo harmonioso indivisível, uma rede de relações dinâmicas que incluem o observador humano e sua consciência de um modo essencial.

Nesse sentido, CAPRA (2002), diz que em contraste à concepção mecanicista cartesiana, a visão de mundo que está surgindo a partir da física moderna pode caracterizar-se por palavras como orgânica, holística e ecológica. Pode ser também denominada visão sistemática, no sentido da teoria geral dos sistemas. O universo deixa de ser visto como uma máquina, composta de uma infinidade de objetos, para ser descrito como um todo dinâmico, indivisível, cujas partes estão essencialmente inter-relacionadas e só podem ser entendidas como modelos de um processo cósmico. Por outro lado, o sistema mecanicista mostra-se bastante importante para o entendimento das partes que compõem um sistema, mas não necessariamente para o entendimento do todo.

A concepção sistêmica vê o mundo em termos de relações e de integração, em vez de se concentrar nos elementos ou substâncias básicas. Embora se possa discernir partes individuais em qualquer sistema, a natureza do todo é sempre diferente da mera soma de suas partes, a sinergia é um componente básico e perde-se na simples visão das partes.

Um outro aspecto importante dos sistemas é sua natureza intrinsecamente dinâmica. Suas formas não são estruturas rígidas, mas manifestações flexíveis, embora estáveis, de processos subjacentes.

A descrição reducionista de estruturas, organismos ou empresas pode portanto, ser útil e, em alguns casos, absolutamente necessária ou única. Ela só é perigosa quando interpretada como se fosse a explicação completa. Reducionismo e holismo, análise e síntese, são enfoques complementares que, usados em equilíbrio adequado, nos ajudam a chegar a um conhecimento mais profundo seja da vida, seja de uma empresa. 
Uma empresa possui muito da plasticidade e flexibilidade internas dos sistemas vivos, cujo funcionamento é controlado mais por relações dinâmicas do que por rígidas estruturas mecânicas, e obedecem ao princípio de auto-organização.

Então, partindo das condições de competitividade impostas pelo mercado, a empresa precisa definir metas ou estratégias que possibilitem sua sobrevivência. Para isso torna-se necessário estabelecer uma filosofia de organização de produtos, processos e relação com o mercado, de forma a tornar a empresa mais competitiva e lucrativa. Nesse sentido, todas as "partes" de uma empresa devem ser avaliadas através de suas inter-relações e não como sendo entidades isoladas, com medições e cobranças individualizadas.

Com isto, pretende-se mostrar que a construção do modelo econômico proposto neste trabalho induz ao raciocínio holístico, sistêmico e dinâmico, de forma a integrar as empresas objeto deste trabalho como um sistema único, medindo a situação de cada produto para cada mercado, bem como sua contribuição na lucratividade da empresa como um todo, integrando as partes da empresa e mostrando a rede de contribuição de cada produto para com o todo, medindo a plasticidade e a flexibilidade internas do sistema.

\subsection{O PROJETO DE PESQUISA}

O presente projeto de pesquisa tem como linha de ação estudar o comportamento econômico de empresas do setor industrial ou de serviços que possuem uma sede central administrativa com várias unidades de negócios dispersas ou não geograficamente, com seus produtos podendo ser vendidos em vários mercados. O objetivo é investigar e analisar o sistema em questão, utilizando os indicadores de posição econômica e o custeio direto como ferramentas de medição.

O modelo econômico proposto levará em consideração os dados referentes ao ambiente interno da empresa, podendo retratar a situação passada, presente e futura, mostrando claramente como os valores econômicos foram obtidos e como se compuseram para formar o resultado final. Os resultados servirão como referencial 
para a simulação de possíveis alterações, avaliando os resultados através de possíveis cenários propostos.

Para tanto, pretende-se modelar o objeto de pesquisa através do custeio direto, desenvolvendo equações dos indicadores econômicos. Para testa a aplicabilidade, a eficiência e a eficácia do modelo desenvolvido será utilizado a metodologia de estudo de caso.

\subsubsection{O Problema}

Segundo LAZZARINI (1995), o objeto ou a unidade de análise é a entidade central do problema de pesquisa. Embora seja normalmente definida como sendo indivíduos, grupos ou organizações, ela pode também ser uma atividade, um processo, um aspecto ou uma dimensão do comportamento organizacional e social.

"Formular o problema consiste em dizer, de maneira explícita, clara, compreensível e operacional, qual a dificuldade com a qual nos defrontamos e que pretendemos resolver, limitando o seu campo e apresentando suas características. Desta forma, o objetivo da formulação do problema da pesquisa é torná-lo individualizado, específico, inconfundível" (RUDIO, 1978:75 apud LAKATOS, 2003:127)

Algumas metodologias de gestão utilizadas atualmente e, muitos dos indicadores gerenciais, principalmente aqueles que de forma direta ou indireta medem a rentabilidade e a lucratividade das empresas são compostos de forma mecanicista e reducionista e, muitas vezes, utilizando-se de métodos de rateio e/ou de direcionadores de custos, causando sérios problemas na tomada de decisão referente à viabilidade de um produto, da venda em um determinado mercado e/ou de uma Unidade de Negócio. Essas metodologias são de difícil implantação, controle e manutenção e, muitas vezes, geram outras despesas indesejáveis na sua manutenção.

Partindo deste pressuposto, o problema está em modelar o sistema objeto deste projeto de pesquisa, retratando a empresa de forma sistêmica e holística, medindo e 
calculando a rentabilidade de cada produto em cada mercado, bem como sua contribuição para as unidades de negócios e para a empresa. A metodologia a ser utilizada deverá ser de fácil implantação, sem custo de manutenção, apresentando resultados de fácil compreensão e análise, gerando dados para auxílio à gestão e tomada de decisão.

\subsubsection{Objetivo Geral e Específico}

O trabalho está inserido nas linhas de pesquisa em Economia da Produção e Engenharia Financeira (EPEF) do Departamento de Engenharia de Produção POLI/USP. Tem como objetivo principal estudar aspectos econômicos na análise de empresas caracterizadas pela existência de uma unidade central administrativa e várias unidades de negócios dispersas ou não geograficamente. Tal objeto será alcançado pela elaboração de um modelo econômico através de indicadores de posição econômica, que utiliza o custeio direto como base geradora de informações.

O foco do trabalho consiste em verificar os impactos econômicos causados na sede central e nas UEN's - Unidades Estratégias de Negócios -, bem como a viabilidade de oferta de produtos em determinados mercados. Para tanto, os estudos serão conduzidos através da elaboração do modelo econômico adequado para analisar os resultados parciais e globais das unidades de negócios e da empresa como um todo, apresentando de forma clara como tais resultados são formados.

Através da implementação do modelo a ser desenvolvido, pretende-se obter elementos capazes de fornecer informações para subsidiar planos, estratégias, oportunidades e suas conseqüências nos resultados econômicos das empresas objeto desta pesquisa.

O trabalho aqui apresentado permitirá também que as empresas objeto de estudo integre seu planejamento estratégico ao modelo econômico desenvolvido, pois na elaboração das metas de superação dos resultados, os executivos podem definir também marcos referenciais para cada medida de posição econômica a ser alcançada para os anos futuros projetados. 
O processo gerencial de planejamento e estabelecimento de metas permite que a empresa possa implementar mecanismos de:

- Quantificação dos resultados pretendidos em longo prazo.

- Identificação de necessidades e fornecimento de recursos para que os resultados sejam alcançados.

- Estabelecimento de referenciais de curto e médio prazo para as medidas de posição econômicas.

\subsubsection{Hipóteses}

Para BUNGE (1976:255 apud LAKATOS, 2003), a ciência impõe três requisitos principais para a formulação de hipóteses: 1) a hipótese deve ser formalmente correta e não se apresentar "vazia" semanticamente; 2) a hipótese deve estar fundamentada, até certo ponto, em conhecimento anterior, caso contrário, volta a imperar o pressuposto já indicado e deve ser compatível, sendo completamente nova em matéria de conteúdo, com o corpo de conhecimento científico já existente; 3) a hipótese tem de ser empiricamente contrastável por intermédio de procedimentos objetivos da ciência, ou seja, mediante sua comparação com dados empíricos, por sua vez controlados tanto por técnicas quanto por teorias científicas.

A partir desse conceito, as hipóteses abaixo formuladas têm por finalidade conduzir o trabalho na busca de respostas que satisfaçam o problema proposto:

1. A um sistema administrativo constituído por uma sede administrativa e várias unidades de negócios é possível associar um modelo econômico esquemático com base no sistema de custeio direto.

2. Uma vez identificadas relações econômicas entre as UENs e a Sede Central, pode-se associar indicadores de posição econômica para se analisar a sensibilidade do resultado da empresa às variações nas quantidades e margens dos produtos em cada UEN.

3. As hipóteses anteriores são aplicáveis tanto às unidades de negócios de produção industrial quanto às de prestação de serviços. 
Se essas hipóteses não forem verificadas e não puderem responder de modo satisfatório ao problema apresentado, deverão ser revistas. Tal reformulação deverá ser de forma adequada para manter a coerência do estudo e apresentar respostas satisfatórias ao questionamento original.

\subsubsection{Variáveis de Pesquisa}

As variáveis independentes que afetam a situação econômica de uma empresa são os custos variáveis, os preços de venda, os custos fixos identificados, os custos/despesas proporcionais ao faturamento e o volume de vendas de cada produto, que influenciam diretamente as seguintes variáveis dependentes: margem bruta de contribuição, margens semi-brutas de contribuição, receita líquida, indicadores de posição econômica e resultados obtidos do sistema estudado.

\subsection{JUSTIFICATIVAS}

Até pouco tempo atrás, a maioria das organizações conseguia gerir e mudar seus negócios com um rol limitado de estratégias, desde que a concorrência fosse estável e as mudanças moderadas.

As profundas modificações no ambiente interno e externo às empresas bem como o aumento da necessidade de adaptação e de respostas cada vez mais rápidas refletiram no crescimento do grau de complexidade de gerenciamento, de controle e do risco nos últimos tempos. As empresas operam hoje em ambientes mais turbulentos, e os altos executivos precisam receber informações adequadas à elaboração de estratégias mais complexas.

Os sistemas de auxílio à gestão utilizados em empresas objeto deste trabalho, normalmente, caracterizam-se a princípio, por tratar cada unidade de negócio de forma isolada, calculando os indicadores de eficiência e o lucro dos produtos/serviços por unidade, não monitorando o inter-relacionamento entre as unidades e a sede administrativa, além de atender às necessidades destas empresas de 
maneira discreta e estática no tempo. Estas metodologias, em geral, são muito complexas em sua implantação e manutenção das informações exigidas para a correta tomada de decisão, causando um aumento nos custos indiretos da empresa.

Por outro lado, as metodologias de gestão desenvolvidas nas últimas décadas caracterizam-se pela visão mecanicista, baseadas no reducionismo, reduzindo a visão estratégica e sistêmica/holística das empresas, promovendo a otimização de setores e/ou processos/atividades que, não necessariamente, levam à melhoria da saúde econômica e financeira a longo prazo.

A relação custo/volume/lucro já foi discutida e analisada por diversos autores para empresas com um ou vários produtos, sem apresentar o efeito de atuação em vários mercados diferentes com suas especificidades/necessidades distintas, medindo e monitorando os produtos em cada mercado e sua contribuição para o todo. Os indicadores de posição econômica (Margem de Segurança e Grau de Alavancagem) são apresentados de forma sucinta, com equações dependentes do ponto de equilíbrio, tornando complexo seu cálculo, já que a identificação do ponto de equilíbrio para empresas com vários produtos torna-se complexa e completamente dependente do mix de produção, pois para essas empresas, existem infinitos pontos de equilíbrio, conforme demonstrado por COSTA (1988).

Por outro lado, pode-se dizer que uma das mais importantes funções da Contabilidade de Custos centra-se no fornecimento de informações às atividades gerenciais de controle, planejamento e tomada de decisões. Estas informações, todavia, não costumam se apresentar adequadamente disponíveis nos relatórios formais de custos, necessitando de determinados tratamentos para que contribuam, de maneira mais eficiente, ao estabelecimento de importantes indicadores de controle e decisão. Neste processo de análise gerencial, também difundido como relação custo/volume/lucro, sobressai-se como um de seus principais instrumentos o ponto de equilíbrio, o qual pode ser mensurado em termos contábeis, financeiros e econômicos.

O modelo proposto está baseado em um modelo de custeio direto, que se apóia na correta alocação dos custos e despesas fixas próprias de um produto ou de uma 
atividade, sem a utilização de métodos de rateio, onde os custos fixos são classificados como custos de período necessários às condições de operação da empresa, eliminando-se assim os mecanismos de medição e alocação (ou direcionadores) de custos e despesas fixas utilizados pelo $A B C$ costing, e dos métodos de rateio utilizados pelo Custeio por Absorção, tornando a aplicabilidade do modelo aqui proposto mais fácil, reduzindo os custos de implementação e manutenção, bem como gerando informações de fácil compreensão.

A importância desta proposta impacta em aspectos extremamente relevantes do ponto de vista de gerenciamento de empresas que se enquadram no perfil apresentado pois, em muitos casos, o empirismo e a falta de metodologia adequada na gestão e na tomada de decisão de pricing e volume de vendas, e a dificuldade de implementação e manutenção de metodologias complexas existentes levam à decisões que não visam maximizar o resultado global da empresa. Por outro lado, o trabalho tem como justificativa principal oferecer ao empreendedor uma visão holística e sistêmica da empresa objeto deste estudo, utilizando-se da modelagem econômica desenvolvida, de forma simples, de fácil implementação e visualização, não precisando muitos conhecimentos financeiros e/ou econômicos para sua interpretação, além de não gerar erros decorrentes dos rateios realizados nos métodos convencionais.

\subsection{METODOLOGIA}

Uma teoria deve, antes de tudo, propiciar solução para um problema que nos interesse. Contudo deve, ainda, mostrar-se compatível com todas as observações feitas e incluir como primeiras aproximações as teorias anteriores - embora deva, ao mesmo tempo, contraditá-las em ponto onde se mostraram falhas e explicar a razão dessas falhas.

Neste trabalho serão utilizadas as definições de método e metodologia de pesquisa apresentadas por THIOLLENT (1986, pp.25): "Podemos distinguir o nível do método efetivo (ou da técnica) aplicada na captação da informação social e a 
metodologia como metanível, no qual é determinado como se deve explicar ou interpretar a informação colhida...... Além de ser uma disciplina a metodologia também é considerada como modo de conduzir a pesquisa. Neste sentido a metodologia pode ser vista como conhecimento geral e habilidade que são necessários ao pesquisador para se orientar no processo de investigação, tomar decisões oportunas, selecionar conceitos, hipóteses, técnicas e dados adequados".

Para o desenvolvimento deste trabalho será utilizado primeiramente a modelagem matemática como ferramenta para descrever o funcionamento econômico e o inter-relacionamento dos sistemas/subsistemas de empresas com sede administrativa central e várias unidades de negócios, verificando a aplicabilidade dos conceitos e definições obtidas, com o objetivo de provar as questões básicas e problemas identificados com a teoria de base. Posteriormente o modelo será aplicado através de estudo de caso em empresas objeto deste trabalho, visado atestar sua aplicabilidade e verificar o atendimento dos objetivos gerais identificados.

\subsubsection{Método de Abordagem}

Neste caso a modelagem matemática serve como instrumento para descrever e reconstruir analiticamente a realidade do objeto de estudo, através do método dedutivo.

Pela indução é possível fazer conclusões gerais a partir de observações empíricas em um processo que vai de uma pressuposição até uma conclusão. Quando utilizamos fatos para gerar uma teoria a eles consistente, estamos utilizando um pensamento indutivo (muitas vezes o primeiro passo nos métodos de pesquisa científico). Já na dedução, pode-se retirar conclusões baseadas em alguns princípios e leis, a partir do raciocínio lógico procurando observar as conseqüências específicas de uma teoria formulada.

Portanto, será utilizado como Método de Abordagem o método dedutivo, usado

por René Descartes, que é apresentado por LAKATOS (2003) através de duas características específicas que contrapõe ao método indutivo, a saber: (a) se todas as 
premissas são verdadeiras, a conclusão deve ser verdadeira; (b) toda informação e o conteúdo factual da conclusão já estava, pelo menos implicitamente nas premissas. Dessa forma, o método não sustenta graduações intermediárias, ou as premissas sustentam de forma completa as conclusões ou não sustentam, suas proposições estão enfocadas na situação geral para explicar as particularidades e chegar à conclusão afirmativa.

\subsubsection{Método de Procedimento}

O Método de Procedimento difere do Método de Abordagem pela inspiração filosófica, pelo grau de abstração e pela finalidade explicativa mais concreta da investigação proposta, situando-se num nível menos abstrato de abordagem do fenômeno. A literatura disponibiliza diferentes métodos de procedimentos para construir uma pesquisa científica:

- Método histórico

- Método Comparativo

- Survey - método estatístico

- Pesquisa experimental

- Estudo teórico conceitual

- Modelagem

- Simulação

- Método funcionalista

- Método estruturalista

- Pesquisa e ação

- Método monográfico - estudo de caso

O método "Estudo de Caso" foi criado por Le Play que o utilizou para estudar famílias operárias na Europa. A metodologia pressupõe que qualquer caso que se estude em profundidade pode ser considerado representativo de muitos outros. A metodologia sugere uma análise aprofundada de um ou mais objetos (casos), com o uso de múltiplos instrumentos de coleta de dados. 
A adoção de tal metodologia em um processo investigatório, remete às considerações de YIN (1994). Segundo o autor, a investigação de um fenômeno contemporâneo dentro do seu contexto real, através de múltiplas fontes de evidência tais como entrevistas, arquivos, documentos e observação, estudando situações onde as fronteiras entre o fenômeno e seu contexto não são claras, é a proposta do estudo de caso como método de pesquisa. Por outro lado LAZZARINI (1995) assinala como vantagem da pesquisa com base em estudo de caso, justamente essa possibilidade de utilizar várias fontes de evidência.

O estudo de caso não deve se restringir única e exclusivamente à fase exploratória de um processo investigatório, podendo mesmo ser utilizado em pesquisas descritivas ou até explanatórias. É desta forma que YIN (1994) contesta a concepção bastante difundida, de que a metodologia em apreço seria apropriada apenas para a fase exploratória de uma pesquisa. Por outro lado, RIEGE (2003) apresenta como argumento fundamental, para utilizar o estudo de caso como metodologia, o problema de pesquisa em si. Em outras palavras: a proposta de pesquisa por si só valida a utilização do método.

Os estudos de caso representam a estratégia de pesquisa que mais se ajusta a situações em que o pesquisador tem pouco controle sobre os eventos, ou quando o foco da análise está restrito a fenômenos contemporâneos, ou ainda quando são colocadas questões do tipo como e por que (LAZARINI, 1995; YIN, 1994).

Por outro lado, LAZZARINI (1995) diz que a pesquisa através de estudos de casos tem sido enquadrada no grupo de métodos denominados qualitativos, que se caracterizam por um maior foco na compreensão dos fatos do que propriamente na sua mensuração. Contrastam, portanto, com os métodos quantitativos voltados mais especificamente para a mensuração dos fenômenos e aplicados a amostras mais extensas. Pesquisas de cunho mais qualitativo seriam mais aplicáveis em situações onde se deseja construir teorias, ao passo que métodos quantitativos seriam adequados ao processo de teste de teorias.

BONOMA (1985 apud LAZZARINI, 1995) sugere que, quando um determinado corpo teórico é bem desenvolvido, o uso de métodos sustentados por 
dados mais qualitativos pode ser ineficaz. Isto porque carregam fortes vieses causados pela subjetividade do pesquisador e normalmente não se aplicam a amostras extensas. Por outro lado, quando o objetivo é construir teorias, evidências de cunho qualitativo podem ser mais eficazes, pois permitirão compreender mais profundamente o fenômeno, dentro do seu próprio contexto.

O método do estudo de caso, na verdade, visa pesquisar eventos da vida real que não podem ser desvinculados de seu contexto mais amplo. Segundo YIN (1994), o estudo de caso surge como método potencial de pesquisa quando se deseja entender um fenômeno social complexo. Tal complexidade pressupõe um nível maior de detalhamento das relações dentro das organizações e entre os indivíduos e organizações, bem como dos intercâmbios que estabelecem com o meio ambiente em que estão inseridos.

LAZZARINI (1995) diz que a idéia de associar o estudo de caso com outros métodos de pesquisa surgiu, basicamente, do incômodo com os baixos "graus de liberdade" envolvidos no método, fato agravado quando se analisa um largo número de variáveis.

Por outro lado, MILES (1979 apud LAZZARINI, 1995), em crítica notória à pesquisa baseada em estudo de caso, argumenta que o método é altamente sujeito a análises "intuitivas, primitivas e incontroláveis". Vai além: "a pesquisa qualitativa em organizações não consegue transcender a simples apresentação de histórias”. A asserção de YIN (1994) é educativa: a percepção comum é que os pesquisadores em estudo de caso terão que aprender somente um conjunto mínimo de procedimentos técnicos, que quaisquer deficiências em habilidades formais e analíticas serão irrelevantes e que o estudo de caso irá permitir que eles simplesmente "contem o caso como ele é". Portanto, a limitação maior do método parece estar relacionada não só com o seu menor rigor científico, mas também com a necessidade de maior habilitação do pesquisador, já que o processo de controle viés torna-se crítico.

Segundo LAZZARINI (1995), se a generalização se der no nível analítico ou teórico, o método torna-se muito útil, principalmente quando o objetivo é auxiliar na elaboração ou no aprimoramento de teorias. Com a utilização do estudo de caso não 
se busca determinar a incidência de um dado fenômeno no seu universo; ao contrário, o enfoque é dado na sua compreensão em nível mais aprofundado. Tal compreensão, para fins de pesquisa, não deve ser buscada sem que haja retroalimentação de um corpo teórico que necessite de consolidação e/ou aperfeiçoamento. Assim sendo, o estudo de caso é particularmente aplicável quando se deseja obter generalizações analíticas, e não estatísticas, que possam contribuir para um certo referencial teórico. Sem este enfoque, o estudo de caso acaba tornando-se apenas uma "história bem contada". De forma básica, pode-se dizer que o método do estudo de caso para fins de pesquisa encaixa-se bem em situações em que o fenômeno é abrangente e complexo, o corpo teórico é insuficiente para estabelecer questões causais, e o fenômeno não pode ser estudado fora do seu contexto sem perda de utilidade da pesquisa.

Apesar da aparente simplicidade da classificação das metodologias de pesquisa existentes, nem sempre parece possível uma distinção tão clara. Na prática da pesquisa podemos encontrar diversas situações em que há superposição de conceitos. Então, a despeito de toda a argumentação apresentada, o estudo de caso, dentro das definições e das propostas apresentadas neste trabalho, se aproxima mais daquilo que temos chamado de pesquisa quantitativa, apesar da dificuldade de generalização dos resultados, podendo o trabalho ser repetido e testado quantas vezes for necessário.

BONOMA (1985 apud LAZZARINI, 1995) afirma que, quando o processo de desenvolvimento de estudo de caso direciona-se à pesquisa, uma revisão cíclica entre teoria, dados e teoria é útil. Neste contexto, o autor sugere que o desenvolvimento operacional do método deve seguir os seguintes estágios: direcionamento, na fase pré-inicial; desenho, em uma fase inicial; predição, em uma fase intermediária; e desconfirmação pelos extremos, na fase final.

A fase pré-inicial, ou de direcionamento, consiste em um estudo prévio do fenômeno enfocado dentro do seu contexto, além da tabulação de conceitos e teorias relevantes ou aplicáveis ao fenômeno. Nesta fase, pretende-se trazer novos insights ao problema de pesquisa que podem até, em certos casos, vir a reformulá-lo. O objetivo básico é explorar e clarificar o fenômeno em estudo, as questões da pesquisa e as hipóteses preliminares. 
A fase de desenho vai um passo além da fase de direcionamento. É a fase em que o pesquisador busca, com afinco, conhecer o que é preciso para estruturar os dados ao redor das proposições da pesquisa. O objetivo básico é avaliar e redefinir as principais áreas da pesquisa, ou seja, aquelas estritamente ligadas ao problema, sugeridas pela fase precedente.

A terceira fase, de predição, ocorre nos momentos intermediários do processo, em que o pesquisador já tem em mãos um modelo teórico preliminar que permite predizer os fenômenos em estudo. Neste estágio, o pesquisador deve trabalhar com a possibilidade de que as eventuais generalizações impostas pelo modelo podem não ser tão gerais como pareciam à primeira vista, sendo, na verdade, específicas a situações e contextos particulares. Deve haver predisposição em reformular o modelo pré-determinado toda vez que existirem conhecimentos que possam vir a desconfirmá-lo, de forma a gerar novas generalizações analíticas (teóricas) que possam sustentar tais conhecimentos.

O último estágio sugerido por BONOMA (1985 apud LAZZARINI, 1995) é o de desconfirmação, que consiste em um teste adicional dos limites das generalizações não rejeitadas no estágio anterior (de predição). O objetivo é analisar casos extremos que possam eventualmente não ser sustentados pelas generalizações teóricas, de forma a estabelecer limites analíticos de tais generalizações.

Apesar da adequação do Método de Estudo de Caso às questões de pesquisa propostas neste estudo, é necessário ter presente as limitações inerentes ao método, conforme discutido, tais como: falta de rigor científico nos procedimentos de pesquisa, necessidade de grande habilidade do pesquisador para controlar potenciais vieses, tamanho reduzido da amostragem, ausência de critérios rigorosos. Portanto, cabe ao pesquisador um papel fundamental no controle das suas conclusões, para que estas não sejam decorrentes de dados deliberadamente enviesados, para simplesmente comprovar suposições iniciais.

Em que pese toda a argumentação favorável de adequação do método às questões de pesquisa propostas neste trabalho, é fundamental ter sempre presente as limitações que são peculiares ao Estudo de Caso. Entre as quais pode-se citar a falta 
de rigor científico nos procedimentos de pesquisa, necessidade de grande habilidade do pesquisador para controlar potenciais distorções, tamanho reduzido da amostra e ausência de critérios amostrais rigorosos (VOSS, TSIRITSIS \& FROHLICH, 2002; LAZZARINI, 1995; YIN, 1994).

\subsubsection{Técnica de Pesquisa}

Da mesma forma que a realização de uma pesquisa exige o uso de métodos definidos de abordagem e de procedimento, exige também o uso de técnicas específicas. Método e técnica são componentes fundamentais do processo de investigação. O método permite estabelecer o roteiro de ação, ou seja, as fases do estudo proposto e com a técnica se estabelecem as formas ou maneiras de como será efetivada a pesquisa (SANTOS, 2003).

Técnicas, portanto, são ferramentas usadas em cada tipo de estudo, em qualquer área do conhecimento humano e se dividem em documentação direta e documentação indireta. $\mathrm{Na}$ documentação indireta incluem-se a pesquisa bibliográfica, a pesquisa documental e os estudos exploratórios, ou seja, todos os tipos de documentos escritos como livros, revistas, jornais, periódicos, filmes, gravações, fotografias e outros registros. Na documentação direta utiliza-se todo tipo de observação direta do fenômeno em estudo e são classificadas em observação direta intensiva e observação direta extensiva.

Segundo LAKATOS (2003) a Observação Direta Intensiva é realizada com as seguintes técnicas:

- Observação: utiliza os sentidos na obtenção de determinados aspectos da realidade. Não consiste apenas em ver e ouvir, mas também em examinar fatos ou fenômenos que se deseja estudar. Pode ser: sistemática, assistemática; participante, não-participante; individual, em equipe; na vida real, em laboratório. 
- Entrevista: é uma conversação efetuada face a face de maneira metódica; proporciona ao entrevistador, verbalmente, a informação necessária. Tipos: padronizada ou estruturada, despadronizada ou não-estruturada, painel.

Para a revisão bibliográfica e desenvolvimento da metodologia será utilizada a técnica de Documentação Indireta, para o estudo de caso a técnica de Observação Direta Intensiva, com os recursos da observação e das entrevistas.

A técnica de Observação será utilizada para entender o funcionamento das empresas escolhidas para a aplicação do estudo de caso, seu comportamento, a interação das unidades de negócios com a sede administrativa/mercado, sendo que ela deverá ser não-participante, individual e na vida real.

Através de entrevistas estruturadas deverão ser identificadas todas as variáveis independentes importantes de entrada do sistema, a fim de aplicar a metodologia desenvolvida, calculando os indicadores de posição econômica, com a utilização de programa a ser desenvolvido no Microsoft Excel para, posteriormente, fazer as análises necessárias e a validação das informações geradas bem como a aplicabilidade do sistema como um todo.

\subsubsection{Tipo de Amostragem}

A escolha das empresas onde se pretende fazer o estudo de caso deverá atender a determinadas características tais como: possuir sede administrativa com mais de uma unidade de negócio, produzir e/ou comercializar mais de um produto em cada unidade de negócio, apresentar uma magnitude de dados e informações que a torne exemplificadora das questões pertinentes a este projeto de pesquisa, além de permitir e facilitar o acesso aos mesmos. 


\subsection{CONTRIBUIÇÃO DO TRABALHO}

O trabalho é dirigido aos profissionais que atuam na gestão de empresas com o perfil estabelecido. O projeto pretende fornecer subsídios para tomada de decisão de gestão de custos, preço de venda, ponto de corte de produto, bem como fornecer o perfil econômico da empresa em determinado momento. O modelo também poderá ser utilizada para auxiliar na construção de projeções futuras para estas empresas.

A contribuição da pesquisa está em modelar o sistema objeto de pesquisa através do Custeio Direto, calculando a margem de contribuição por produto, linha de produtos e/ou áreas estratégicas de negócios, além do resultado final (lucro) de cada unidade de negócio e sua contribuição para o resultado global da empresa.

A modelagem matemática fornece dados para o desenvolvimento dos indicadores de posição econômica: margem de segurança, grau de alavancagem operacional grau de alavancagem combinado e ponto de equilíbrio, integrando-os a um sistema único e dinâmico que possa auxiliar não só a gestão da empresa em nível global, de suas unidades/sede.

O modelo ainda apresenta ferramentas para que o gestor possa medir o comportamento da empresa mediante as modificações mercadológicas, bem como auxiliando na determinação das metas de vendas de cada Unidade de Negócios e/ou de cada mercado em que a empresa esteja atuando, podendo ser utilizado como instrumento para auxílio a tomada de decisões estratégicas, auxílio a medição do planejamento estratégico e a prospecções futuras.

Outra contribuição importante é a aplicação da metodologia integralmente em uma Instituição de Ensino Superior privada, mostrando que a metodologia pode ser aplicada no setor de serviço sem restrições.

Em síntese, o mérito maior deste projeto é analisar o sistema administrativo em questão utilizando os indicadores como ferramentas de medição do sistema. 


\subsection{ORGANIZAÇÃO DO RELATÓRIO FINAL}

No Capítulo-2 é conduzida uma revisão bibliográfica dos sistemas administrativos existentes na literatura, apresentando as estruturas organizacionais e as definições de Unidades Estratégicas de Negócios, objetivando definir a estrutura organizacional objeto do trabalho, as limitações e a abrangência da aplicabilidade da metodologia desenvolvida.

No Capítulo-3 é apresentada uma revisão bibliográfica do Custeio Direto, definindo suas aplicações, limitações e a aplicabilidade do método. Neste capítulo foi desenvolvido um modelo matemático do Custeio Direto para a estrutura organizacional proposta no Capítulo-2, e uma adaptação da representação esquemática do modelo econômico da empresa apresentado por BRUNSTEIN (1987).

Toda a teoria apresentada neste capítulo é de fundamental importância, pois o desenvolvimento teórico dos Indicadores de Posição Econômica, bem como a interpretação dos resultados obtidos, apresentados nos Capítulos-4 e 5 estão apoiados nos conceitos do Custeio Direto discutidos e apresentados no Capítulo-3.

Por outro lado para a identificação das Variáveis Independentes, quando da aplicação da metodologia proposta que será apresentada em forma de Estudo de Caso no Capítulo-6; primeiramente deve-se aplicar o Custeio Direto na empresa, verificando sua aplicabilidade na integra, de forma a gerar as informações necessárias para o cálculo e análise dos indicadores desenvolvidos.

No Capítulo-4 é apresentada uma revisão bibliográfica dos Indicadores de Posição Econômica: Ponto de Equilíbrio, Margem de Segurança e Grau de Alavancagem Operacional.

O Ponto de Equilíbrio é apresentado sob várias óticas, desenvolvendo as equações, suas interpretações e as limitações do método. Primeiramente, toda a análise foi realizada para empresas com produção e comercialização de um único produto, estendendo posteriormente as equações e análise para empresas com multiprodutos. Neste capítulo é apresentado também todo o desenvolvimento e 
interpretação da Margem de Segurança e do Grau de Alavancagem Operacional apresentados por BRUNSTEIN.

No Capítulo-5 é realizada a modelagem econômica do sistema administrativo proposto. Com base nas teorias apresentadas nos Capítulos-3 e 4, foi desenvolvido novas equações para o caso de empresas com sede administrativa e várias unidades de negócios, e uma aplicação com base em um exemplo teórico, objetivando a apresentação formal da metodologia.

No Capítulo-6, é apresentado o estudos de caso e a validação da metodologia desenvolvida. Por fim, no Capítulo-7, as conclusões finais desta Tese. 


\section{DESCRIÇÃO DO SISTEMA ADMINISTRATIVO}

Embora alguns autores mais modernos de teoria administrativa, cada vez mais em número crescente, venham criticando as organizações contemporâneas quanto ao excesso de formalismo na observância do modelo burocrático e de estruturas rígidas de autoridade, acenando com a possível substituição dessas características nas organizações do futuro, acreditamos que ainda teremos que falar sobre o assunto, pelo menos por mais algumas décadas.

CURY (2000), diz que a estrutura organizacional atende a três funções básicas:

- as estruturas tencionam realizar produtos organizacionais e atingir metas organizacionais;

- as estruturas destinam-se a minimizar ou pelo menos regulamentar a influência das variações individuais sobre a organização. Impõem-se estruturas para assegurar que os indivíduos se conformem às exigências das organizações e não o inverso;

- as estruturas são os contextos em que o poder é exercido, em que as decisões são tomadas e onde são executadas as atividades organizacionais.

Deve-se ressaltar que a palavra estrutura pode ter dois significados distintos: o primeiro referente às partes físicas da empresa, relacionadas com o espaço, equipamentos etc.; a segunda, objeto deste trabalho, compreende a disposição das diversas unidades que compõem a empresa - departamentos, divisões, seções etc.

Por outro lado, segundo CHIAVENATO (1993), o movimento de Desenvolvimento Organizacional (D.O.) surgiu a partir de 1962, não com um único autor, mas com um complexo conjunto de idéias a respeito do homem, da organização e do ambiente, no sentido de propiciar o crescimento e o desenvolvimento segundo as suas potencialidades. No sentido restrito, D.O. é um desdobramento prático e operacional da Teoria Comportamental a caminho da abordagem sistêmica. Não se trata de uma teoria administrativa propriamente dita, mas de um intenso movimento congregando diversos autores no sentido de aplicar as 
ciências do comportamento (principalmente a teoria comportamental) na Administração.

Nesse contexto, o conceito de Desenvolvimento Organizacional está intimamente ligado aos conceitos de mudança e de capacidade adaptativa da organização à mudança. Ainda, segundo CHIAVENATO (1993), o D.O. parte de conceitos dinâmicos, como:

- um novo conceito de organização;

- conceito de cultura organizacional;

- conceito de mudança;

- conceito de desenvolvimento;

- fases da organização;

- críticas às estruturas convencionais.

Então, toda organização atua em determinado meio ambiente e sua existência e sobrevivência dependem da maneira como ela se relaciona com esse meio. Assim, ela deve ser estruturada e dinamizada em função das condições e circunstâncias que caracterizam o meio em que ela opera.

\subsection{ESTRUTURAS ORGANIZACIONAIS}

Para representar a estrutura organizacional, deve ser utilizado o gráfico universal denominado organograma - o organograma é conceituado como a representação gráfica e abreviada da estrutura da organização. Existem vários tipos de organogramas, alguns simples, outros sofisticados e até complexos. Para exemplos deste trabalho, será utilizado somente o mais simples, que é o clássico ou tradicional, de grande objetividade, atendendo plenamente ao fim a que se destina.

Segundo CERTO (1993), a evolução das estruturas organizacionais normalmente encontradas consiste em: a simples, a funcional, a divisional, a de 
Unidades Estratégicas de Negócios (UEN) e as estruturas-matriz. Um diagrama esquemático de cada um dessas estruturas é mostrado na Figura-2.1.

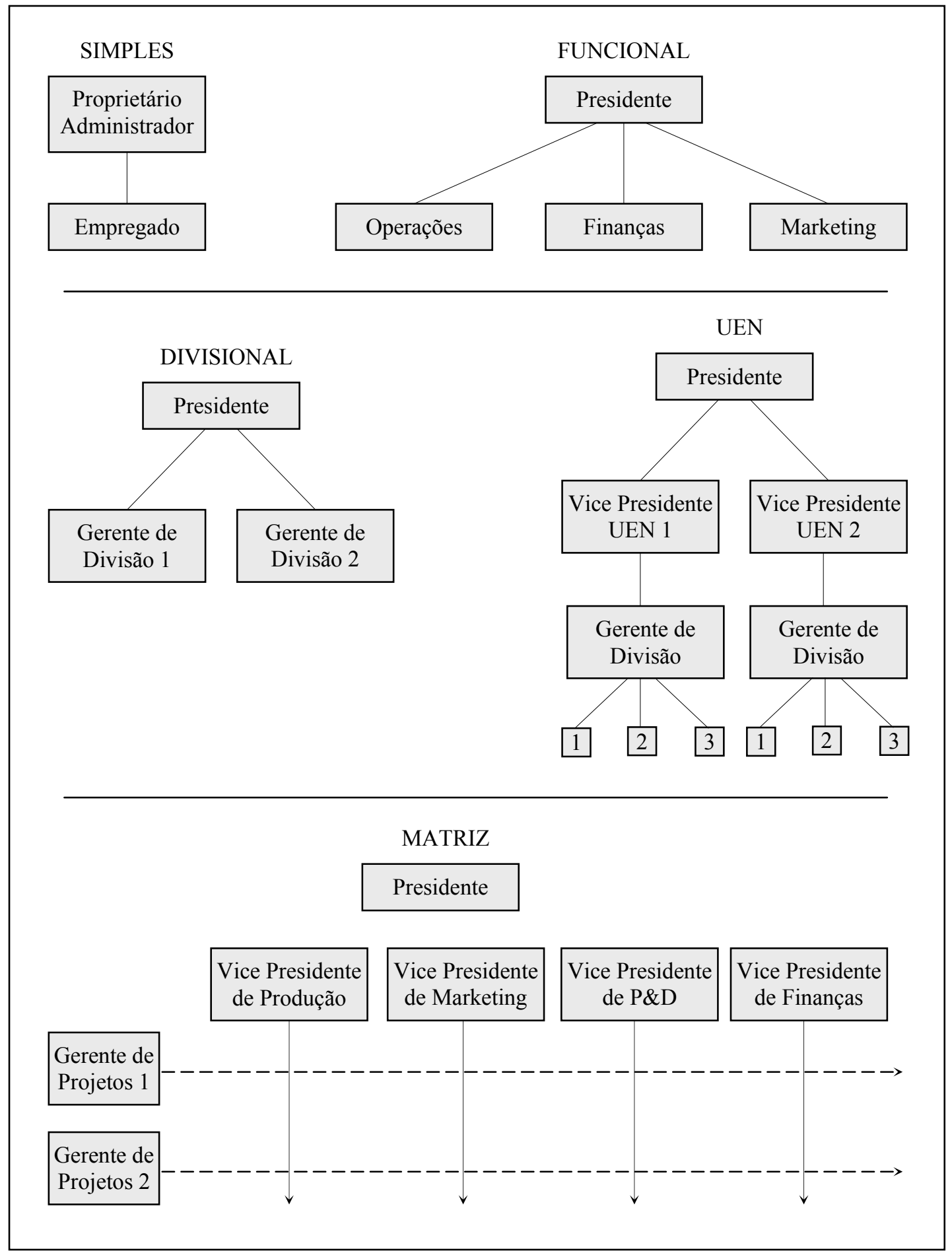

Figura 2.1 - Os cinco tipos de estruturas organizacionais. (CERTO, 1993, pp.166) 


\section{Estrutura Organizacional Simples:}

Uma estrutura organizacional simples tem somente dois níveis, o do proprietário-administrador e o dos empregados. Pequenas empresas com um único ou somente alguns produtos têm este tipo de estrutura. A sua principal vantagem é permitir uma implementação rápida e flexível de estratégias. Esta vantagem é a razão primária por que, algumas vezes, as pequenas empresas podem concorrer efetivamente com gigantes da indústria.

\section{Estrutura Organizacional Funcional:}

Uma organização cresce e desenvolve diversos produtos e mercados relacionados; freqüentemente suas estruturas mudam para refletir a maior especialização nas áreas funcionais de negócios. Funções de linha como operações, marketing e pesquisa e desenvolvimento (P\&D) podem ser organizadas em departamentos. As estruturas organizacionais funcionais também podem incluir diversos departamentos e equipes, como finanças e contabilidade ou pessoal e administração, que se reportam diretamente ao presidente. A especialização é uma das principais vantagens da estrutura funcional; ela promove o desenvolvimento de uma maior experiência em cada área. Entretanto, esta estrutura talvez leve a problemas de coordenação entre departamentos que podem impedir a sua implementação de forma eficiente.

\section{Estrutura Organizacional Divisional:}

À medida que a empresa adquire ou desenvolve novos produtos em diferentes indústrias ou mercados, ela pode evoluir para uma estrutura organizacional divisional. Cada divisão pode operar de forma autônoma sob a direção de um gerente de divisão, que se reporta diretamente ao presidente. As divisões podem basear-se em linhas de produtos (automóveis, aviões), mercados (consumidores, compradores industriais), áreas geográficas (norte, sul, internacional) ou canais de distribuição (lojas de varejo, vendas por catálogo).

Cada divisão não somente tem a sua própria linha e funções hierárquicas para gerenciamento como também formula e implementa estruturas próprias com 
a aprovação do presidente. A organização global tem posições hierárquicas (como vice-presidentes ou administradores e operações) para auxiliar nas atividades de coordenação e na alocação de recursos. A estrutura organizacional divisional oferece às grandes companhias uma forma de permanecer junto a seus mercados, mas, como as diferentes divisões podem competir entre si por recursos, conflitos também podem ocorrer.

\section{Estrutura de Unidades Estratégica de Negócios (UEN):}

Quando uma estrutura divisional se torna inviável porque o presidente tem divisões em excesso para administrar de forma efetiva, as organizações podem se reorganizar na forma de unidades estratégicas de negócios (UEN). Esta estrutura agrupa diversas divisões entre si que podem ser projetadas com base na similaridade de linhas de produtos ou de mercados. Os vice-presidentes são responsabilizados pelo funcionamento das unidades de negócios recém-formadas, e esses executivos reportam-se diretamente ao presidente. A estrutura UEN pode ser útil na coordenação de divisões com problemas e oportunidades estratégicas similares e, dessa forma, pode facilitar a implementação da estratégia. Entretanto, como ela impõe outra camada hierárquica de administração à estrutura, também pode reduzir a velocidade de tomada de decisões e retardar o processo de implementação, a menos que a autoridade seja descentralizada.

\section{Estrutura Organizacional de Matriz:}

Uma estrutura organizacional de matriz é usada para facilitar o desenvolvimento e a execução de diversos programas ou projetos. Conforme mostrado na Fig-2.1, cada um dos vice-presidentes de departamentos listados no topo tem responsabilidades funcionais para com todos os projetos, enquanto cada um dos administradores listados abaixo, na lateral, tem responsabilidades de projeto pelo término e implementação da estratégia. Esta abordagem permite que os administradores dos projetos atravessem linhas departamentais e possam promover uma eficiente implementação das estratégias. Entretanto, ela tem uma importante desvantagem; freqüentemente os empregados ficam confusos sobre 
suas responsabilidades de trabalho e se são responsáveis perante o administrador do projeto ou perante seus administradores de grupo funcional.

Já CURY (2000), com uma visão moderna, apresenta as estruturas organizacionais através de outra concepção:

- Estruturas Tradicionais:

- Estrutura linear ou militar - representada graficamente por uma pirâmide, demonstra claramente a unidade de comando e o princípio de escalonamento hierárquico, sendo um tipo de estrutura baseado na organização dos antigos exércitos.

- Estrutura funcional - fundamentada na técnica da supervisão funcional, tendo sido planejada para implantar as idéias de Taylor e tem larga aplicação na base da organização, em que prevalece a especialização.

- Estrutura staff-and-line - segue as características básicas da estrutura linear, distinguindo-se desta pela existência de órgãos de staff junto aos gerentes de linha. Esses órgãos de staff têm a função de assessoramento e de aconselhamento ao executivo ao qual estão ligados.

- Estrutura tipo comissão ou colegiada - neste caso há o advento da administração plural, com o conseqüente declínio da chefia singular, como uma estratégia para enfrentar de maneira mais adequada o processo de tomada de decisão, dificultado ainda mais pela diversidade e complexidade das múltiplas funções desenvolvidas. Assim, na chefia colegiada, não mais existe um grande chefe tomando as decisões políticas e estratégias da empresa, mas uma pluralidade de membros de diferentes profissões,

\section{- Estruturas Modernas:}

- Estrutura com base em função - a principal característica desse tipo de agrupamento é a natureza das atividades do trabalho. Assim, pode-se conceituar a estrutura com base em função como aquela em que as atividades análogas, interdependentes, que se encadeiam num propósito dominante da empresa, são agrupadas num órgão 
específico constituindo a grande unidade setorial da instituição. Onde todas as atividades/tarefas, são centralizadas num único órgão, geralmente o departamento, dirigido por um executivo, observando o princípio da unidade de direção, de Fayol.

- Estrutura divisional - quando grandes organizações começaram a enfrentar as dificuldades apontadas para a estrutura funcional, em virtude das mudanças de seu ambiente e decorrência da alta diversificação adotada, procedeu-se à divisão da estrutura existente em unidades de maior flexibilidade operacional, traduzindo-se na adoção de uma estrutura divisional. Pode-se conceituá-la como aquela em que atividades díspares, mas vinculadas a um objetivo final específico, são grupadas em uma mesma unidade organizacional, geralmente denominada "divisão de produção de....", encontrando-se, também, denominações como grupos e/ou departamentos.

\section{- Estruturas Contemporâneas:}

- Estrutura com base em projeto - a administração de projetos foi a solução encontrada para a administração de um projeto específico que, por seu porte, complexidade, importância, tecnologia emergente, com um fim definido e um envolvimento organizacional, exigindo relações horizontais e diagonais, vem justificar sua exclusividade. Nesse caso, todos os recursos para se atingir determinado objetivo, que se enquadra na concepção de projeto, são separados da estrutura com base em função de rotina, e agrupados em uma unidade independente, chefiada por um gerente de projeto, que deverá ter sob sua orientação todos os especialistas alocados.

- Estrutura matricial - é uma solução mista em que normalmente se combina a estrutura com base em função com as estruturas com base em projetos ou em produtos. Assim, ao revés de a organização adotar grupos de produtos ou de projetos independentes, cada um com suas próprias subestruturas funcionais, os órgãos funcionais centrais 
continuam com suas estruturas características, apoiando as gerências tanto de projetos quanto de produtos.

\section{- Estruturas Elementares:}

- Unitária - é utilizada para indicar que se trata de uma estrutura unificada, permanecendo somente como uma unidade, não podendo nenhuma subparte, deve subsistir por si própria. Exemplificando, o departamento de $\mathrm{P} \& \mathrm{D}$ por si só não teria produto para vender, sozinha, a área de produção não teria projetos com que trabalhar; o marketing, isoladamente, seria inócuo. Portanto, nenhuma função solitariamente, poderia avaliar seu desempenho, ter seu próprio produto ou ser tratada como um centro de lucro, sendo que cada unidade é totalmente dependente das demais, tendendo a ser uma empresa altamente centralizada.

- Holding - é aquela em que as unidades subordinadas são empresas independentes, mantendo a cúpula dirigente um staff para o controle econômico-financeiro do grupo.

- Multidivisional (Unidade Estratégica de Negócios) - existem múltiplas divisões, cada qual desenvolvendo seu negócio (autos, geladeiras, tratores, máquinas etc). Cada divisão pode também ser chamada de Unidade Estratégica de Negócio.

- Estruturas das Organizações de Alto Desempenho: as organizações de alto desempenho, com seu ambiente desafiador, incerto, envolvente e turbulento, passaram a utilizar-se com mais freqüência dos trabalhos em pequenas células (ou grupos), com o objetivo de ganhar vantagem competitiva, num mercado cada vez mais acirrado, de concorrentes dispostos a tudo para satisfazer o cliente.

WRIGHT (2000), descreve algumas das estruturas organizacionais apresentadas acima, apresentando-as através de uma outra metodologia, acrescentando a estrutura Keiretsu, que é uma forma japonesa de organização. A estrutura Keiretsu representa um grupo de empresa conectadas de forma horizontal e vertical, com conselheiros inter-relacionados que são altos administradores de empresas que fazem parte do grupo. Essas empresas também têm participação 
acionária mútua. Os membros desse tipo de organização muitas vezes fazem joint ventures entre si e assinam acordos recíprocos de compra.

\subsection{UNIDADE ESTRATÉGICA DE NEGÓCIO - UEN}

Segundo PORTER (1992), com o desenvolvimento e a prática do planejamento estratégico, a maioria das empresas começou a reconhecer dois tipos de estratégia: estratégia corporativa e estratégia das unidades empresariais. A estratégia das unidades empresariais expõe o curso das atividades de uma empresa em industrias individuais, enquanto a estratégia corporativa aborda a composição do portfólio de unidades empresariais de uma empresa. Refletindo esta distinção, a maioria das grandes empresas dividiu seus negócios em algum tipo de unidade estratégica de negócio (UEN), e instituiu processos de planejamento formais onde as UEN's submetem planos para revisão pela alta gerência em uma base anual ou semestral. Ao mesmo tempo, a estratégia corporativa vem sendo vista cada dia mais como gerência de portfólio, normalmente usando alguma variação das técnicas de planejamento de portfólio amplamente adotadas nos anos setenta.

A estrutura por UEN pressupõe, na maior parte das vezes, todas as premissas de estrutura por produtos (ou famílias de produtos), acrescida de outras premissas que são, basicamente, específicas de estrutura por UEN.

Segundo FUSCO (1996), uma UEN pode ser encarada como uma "unidade de planejamento", definida em termos de necessidades e oportunidades estratégicas.

SLACK (1993) estende tal conceito ao nível operacional, trazendo à UEN uma feição verdadeiramente de uma unidade de negócios na acepção do termo, com todas as implicações decorrentes, tal como autonomia de gestão operacional, estratégia de operações dirigida e outras; resultando em unidades de negócios relativamente independentes, com características próprias de negociação e aproveitamento das oportunidades de mercado. 
OLIVEIRA (2001), ressalta que dentro da realidade que se verifica na maior parte das empresas, o aspecto básico é a falta de uma premissa de atuação administrativa voltada para resultados. Outra premissa que as empresas devem considerar no estabelecimento de uma filosofia de administração por UEN é ter melhor interação na relação produtos e serviços com os segmentos de mercado.

Nessa relação produto e mercado, a empresa deve debater algumas formas para o estabelecimento de uma UEN, as quais estão mais vinculadas às características de mercado, tais como:

- preços e qualidade;

- clientes;

- concorrentes;

- fornecedores etc.

Neste sentido, a utilização de UEN induz o estabelecimento de uma forma de relação da empresa com o mercado, sendo que, entretanto, algumas vezes de maneira inversa, o mercado relaciona-se com a empresa por meio das AEN (Área Estratégica de Negócios). A AEN é uma área de oportunidade com necessidades atendidas em função do tipo de cliente, distribuição geográfica ou tecnologia utilizada. Sobre esses aspectos, nota-se que o mesmo mercado atendido por duas tecnologias diferentes pode ser caracterizada por duas AEN.

Por outro lado, segundo ANSOFF (1993), uma Área Estratégica de Negócio (AEN) corresponde a um segmento distinto do ambiente no qual a empresa atua ou pode atuar. Uma AEN é um segmento do ambiente, sendo que uma UEN é uma unidade de uma empresa encarregada de uma ou mais AEN's.

Ainda, segundo ANSOFF (1993) o trabalho pioneiro no desenvolvimento da visão voltada para o ambiente foi feito por R. Mcnamara e C. J. Hitch no departamento da Defesa dos Estados Unidos, quando criaram a "fatia de missão" - o correspondente militar de uma AEN.

Na empresa, o pioneiro foi a General Electric Company, que desenvolveu um conceito complementar chamado unidade estratégica de negócio (UEN), que é uma 
unidade de uma empresa responsável pelo desenvolvimento da posição estratégica da empresa em uma ou mais AEN's (Figura-2.2).

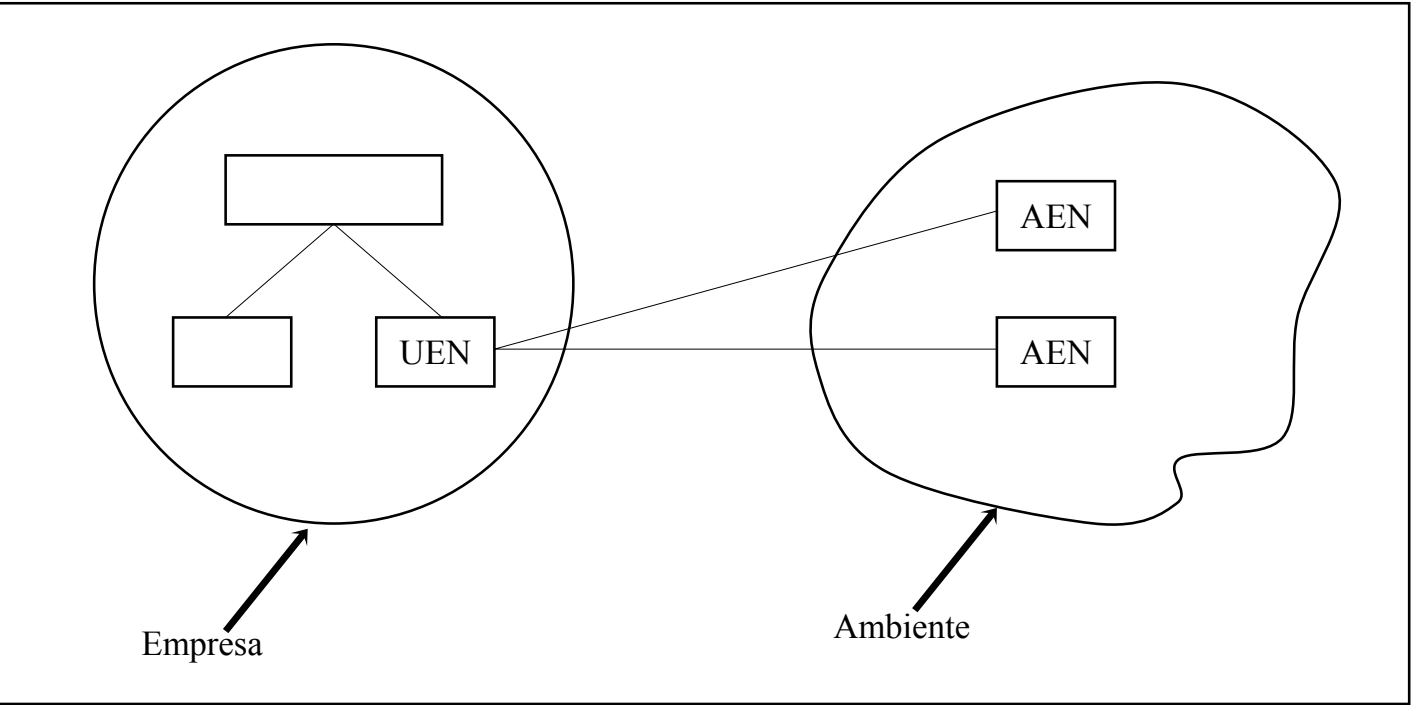

Figura 2.2 - AEN versus UEN. (ANSOFF, 1993, pp.78)

Neste sentido, a General Electric associou as unidades operacionais existentes as AEN's da empresa, responsabilizando assim suas UEN's não apenas pelo planejamento e pela implantação de estratégias, como também pela obtenção subseqüente de lucros. Este enfoque elimina a necessidade de cruzar fronteiras organizacionais e unifica a responsabilidade por lucros e perdas numa UEN. Mas, como tem sido constatado, a estrutura organizacional tradicional não se encaixa perfeitamente nas novas AEN's identificadas, e as responsabilidades resultantes não são bem definidas e claras.

A definição de UEN adotada pela General Elétric (apud, BUZELL, 1991):

"Uma unidade de negócio é uma divisão, linha de produtos ou outro centro de lucro de uma empresa que:

- Produz e comercializa um conjunto bem definido de produtos e/ou serviços correlatos. 
- Serve um conjunto claramente definido de clientes, numa área geográfica razoavelmente bem delimitada.

- Compete com um conjunto bem definido de concorrentes."

No caso da Norton Company (apud, BUZELL, 1991), fabricante americano de abrasivos, houve a opção de tratar os abrasivos revestidos e aqueles à base de ligas metálicas como duas unidades separadas.

Os executivos da Norton reconheceram que:

- As duas linhas de produtos eram adquiridas em grande parte, por clientes diferentes e para aplicações diferentes.

- O concorrente mais forte da Norton em abrasivos revestidos, a 3M, não participava de forma alguma do mercado de abrasivos de ligas metálicas.

Consequentemente, as questões estratégicas que eram importantes para as duas linhas de produtos eram significativamente diferentes, muito embora utilizasse as mesmas matérias primas e fossem vendidas pela mesma equipe de vendas.

Ainda, segundo ANSOFF (1993), outra solução é reorganizar a empresa de acordo com AEN's para que haja uma correspondência unívoca entre AEN's e UEN's. Esta solução aparentemente simples também não está livre de dificuldades, porque a eficácia do desenvolvimento estratégico, que é o critério de projeto de organização usado na identificação de UEN's, é apenas um dos principais determinantes da estrutura organizacional. Os outros são o emprego eficaz da tecnologia da empresa e a eficiência da geração de lucros. Uma reorganização de acordo com AEN's, maximizando a eficácia do comportamento estratégico pode, portanto, comprometer o desempenho da empresa em termos de rentabilidade, ou pode ser inviável em vista de considerações tecnológicas.

Verifica-se que o estabelecimento da UEN baseia-se em atividades da empresa que precisam ser entendidas e segmentadas estrategicamente no mercado, de forma que os recursos possam ser alocados de melhor maneira para se conseguirem vantagens competitivas efetivas. 
Embora ocorra determinada dificuldade em seu estabelecimento, existem algumas premissas que podem ser utilizadas para o delineamento das UEN, a saber:

- estar relacionada a um segmento específico;

- ter vantagem competitiva real e efetiva;

- ter melhor adequação geográfica;

- ter uma única missão ou negócio, independente de outras UEN (ou, preferencialmente, estar na missão do grupo empresarial);

- ter um conjunto de concorrentes claramente definidos;

- competir em mercados específicos;

- ser capaz de desenvolver um planejamento integrado, independentemente de outras UEN;

- ter um responsável pelo planejamento e resultados de UEN;

- ser capaz de administrar recursos;

- operar em um único segmento de mercado com estratégia concentrada;

- parecer e agir como um negócio independente.

De maneira geral, pode-se afirmar que, à medida que se aumenta o nível de diversificação das empresas, fica mais difícil estabelecer suas estratégias e, portanto, é necessário criar novas UEN's e, de forma geral, pode-se considerar que a amplitude deve estar num contínuo, desde atuando como unidade de vendas até estar atuando como unidade mais completa ( $\mathrm{P} \& \mathrm{D}$, suprimentos, produção, marketing e apoio admonistrativo-financeiro).

Entretanto, na maior parte das vezes, segundo OLIVEIRA (2001), tem-se considerado como ideal que a UEN englobe as seguintes atividades:

- P\&D;

- Produção; e

- Vendas.

Isso porque os itens relacionados abaixo devem ser centralizados na sede administrativa:

- Suprimentos devem ser, na maior parte das vezes;

- Apoio administrativo-financeiro; e 
- Marketing, em seu sentido mais amplo (estratégias de mercadológicas, análise de mercado, propaganda, promoção etc.).

Salienta-se que essa é uma afirmação genérica e que cada empresa deve ter uma análise específica. Cada uma das UEN's deve ser desmembrada, para facilitar sua administração, em termos de produto, grupo de produtos, localização geográfica etc. Esta decomposição facilitará uma melhor interação de cada um dos produtos ou famílias de produtos em diferentes segmentos de mercado.

Portanto, segundo FUSCO (1996), o objetivo básico é possibilitar a avaliação dos negócios explorados nas diversas UEN's, como ferramenta para tomada de decisões quanto à alocação de recursos, aquisição ou liquidação de UEN's.

Atualmente, predomina a visão da UEN como sendo uma "célula de planejamento" para facilitar o processo de formulação de estratégias, bem como a mensuração e comparação dos resultados de UEN's que diferem em termos de mercados concorrentes, sistemas de produção, operação e outros fatores.

Nesse sentido, as UEN's podem ou não corresponder às fronteiras existentes entre divisões de produtos, incluindo normalmente várias linhas de produtos, tipos de clientes, áreas de mercado distintas e, segundo FUSCO (1996), é importante considerar que todas as UEN's estão interligadas, o que significa dizer que devem ser assumidos alguns trade-offs, por exemplo, preços versus qualidade, produtividade da força de trabalho versus mecanização, aumento de produtividade versus investimentos para consegui-la etc.

\subsection{PARA QUE SERVE A UNIDADE ESTRATÉGICA DE NEGÓCIOS? ${ }^{1}$}

A grande razão reside na determinação dos potenciais relativos de lucros de muitas UEN's diferentes na carteira de uma empresa, com base em suas posições

1 Tópico adaptado da Tese apresentada à Escola Politécnica da USP, em 1996 - "Gestão competitiva de preços uma visão integrada”, por José Paulo Alves Fusco, pp. 33. 
competitivas correntes e em alterações futuras esperadas em fatores, tais como tamanho de mercado, qualidade do produto e lançamento de novos produtos.

Adicionalmente, quanto mais diversificados forem os negócios explorados, os diversos fatores relacionados às diferentes áreas de atuação da empresa, tais como clientes, concorrência, características de produtos, fornecedores etc., não devem ser analisados de uma mesma forma em função dos diferentes contextos a atender.

O objetivo básico é possibilitar a avaliação dos negócios explorados nas diversas UEN's, como ferramenta para tomada de decisões quanto à alocação de recursos, aquisição ou liquidação de UEN's. Representa uma tentativa no sentido de não perder de vista a realidade operacional dos negócios, sem deixar, no entanto,de utilizar um nível mais elevado de agregação.

Os procedimentos de análise podem ser estabelecidos de maneira mais sistemática, facilitando a obtenção das estratégias empresariais, porque a distância organizacional se torna menor e possibilita uma aderência maior a perspectiva do plano em relação ao que efetivamente ocorre.

\subsubsection{Benefícios da Adoção do Conceito de UEN}

a) A definição de UEN permite obter unidades operacionais mais focalizadas, trazendo ganhos na curva de experiência dos processos envolvidos, agilidade operacional e maior aderência dos controles e decisões gerenciais.

A focalização em um horizonte mais estreito ou direcionado simplifica a tarefa de análise do planejador, uma vez que facilita a visualização dos fatores "qualificadores" e "ganhadores de pedidos" (HILL, 1989), correspondentes ao negócio típico de cada UEN.

Isto pode trazer diretamente, no curto prazo, um adicional de qualidade na obtenção dos produtos/serviços, o que significa que a empresa pode trabalhar vendendo a preços mais elevados do que a concorrência, auferindo maiores lucros. 
Pesquisas envolvendo as UEN's da base PIMS - "Profit Impact of Marketig Strategies" (apud BUZZEL, 1991), demonstraram na prática que aquelas que se situavam no terço superior em termos de qualidade relativa, vendiam seus produtos ou serviços, em média, a preços 5 a $6 \%$ mais altos do que aquelas situadas no terço inferior.

b) No longo prazo, qualidade superior pode ser encarada como a maneira mais eficaz de crescer. Estudos realizados por BUZZEL, demonstram que a qualidade leva a ampliação da participação no mercado, trazendo vantagens em termos de escala, ROI (Retorno Sobre o Investimento) e ROS (Retorno Sobre Vendas).

No entanto, é importante lembrar que o valor de uma UEN deve ser entendido de forma global, como sendo a capacidade que o seu negócio possui de gerar uma ação de alavancagem estratégica no portfólio da empresa.

TUCKER (1981), coloca o conceito de contribution pool, ou seja, um somatório de todas as contribuições (positivas e negativas) geradas na empresa, o qual pode ser encarado como sendo a capacidade efetiva de auto-financiamento considerando todos os negócios.

c) Cria uma base mais consistente de conhecimento, condição vital para a implantação, de forma sustentada, de sistemas de gestão modernos.

A adoção de UEN's permite ao planejador proceder a uma análise mais completa dos negócios da organização, simplifica o processo de planejamento e proporciona melhor qualidade e consistência com a realidade, ao elenco final de estratégias obtidas.

d) Permite racionalizar os investimentos necessários para atingir o mesmo objetivo, aumentando a eficiência do sistema na utilização de recursos financeiros.

e) Permite identificar claramente quem gera dinheiro e quem consome, de modo a estabelecer missões específicas em função das previsões para cada setor específico e a empresa como um todo. 
f) Permite maior poder de análise da concorrência e melhoria da qualidade das decisões correspondentes às alternativas de parceria, investimentos, simulações de operações, bem como estabelecimento de objetivos mais condizentes com a realidade de mercado.

\subsection{FATORES CRÍTICOS DE SUCESSO}

O desempenho de uma UEN depende de todas as políticas e de todos os programas ou processos que ocorrem internamente e suas relações com o mercado. Neste sentido, BUZZEL (1991), sugere a necessidade de aferir medidas de posição competitiva e estratégica, através de benchmarketing com a concorrência, objetivando ser melhor em tudo aquilo que realmente importa, apresentado na Figura-2.3.

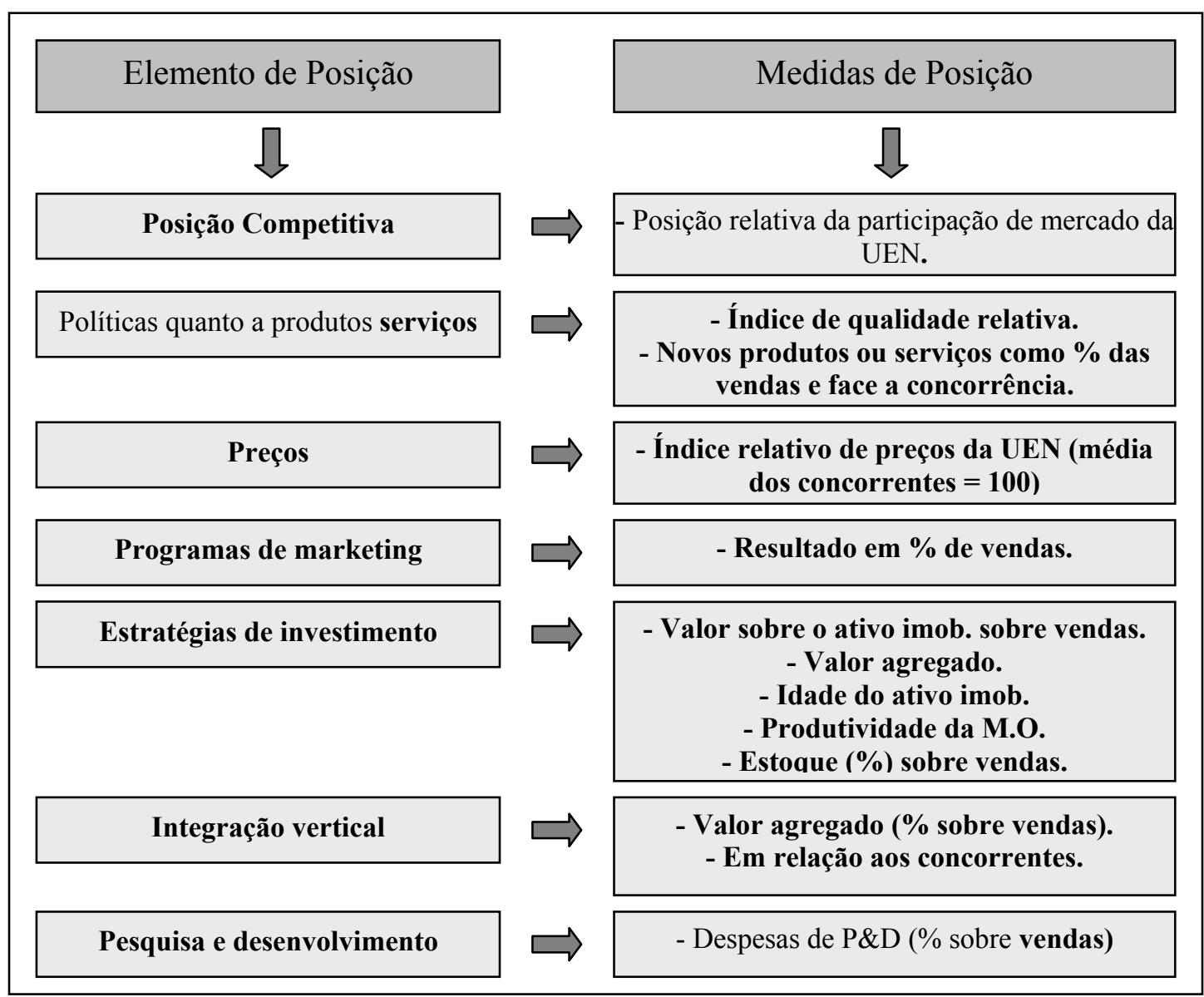

Figura 2.3 - Dimensões Importantes de Posição Competitiva. (BUZZEL, 1991) 
O processo de obtenção da estratégia de uma UEN como sendo o resultado da ponderação de duas grandes dimensões, dimensão de conversão e dimensão de posicionamento. Onde cada setor da economia requer uma determinada intensidade de cada dimensão, sendo ambas conseqüência da intensidade competitiva de cada setor econômico.

- Dimensão de Conversão, que significa a transformação de recursos em produtos, englobando aí, portanto, todos os processos produtivos e de logística, envolvendo desde os recursos ou fatores de produção até os produtos finais.

- Dimensão de Posicionamento, que envolve uma discussão e decisão completa sobre o negócio, ou seja, decidir o conceito do negócio.

FUSCO (1996), afirma que decidir o conceito de um negócio significa decidir um ajuste entre uma categoria de mercado e uma categoria de produto. Sendo que categoria de mercado pode ser definida como a amplitude da expectativa dos consumidores que deve ser coberta, e a categoria de produto é a amplitude de variedade diferenciada de produtos que é configurada para satisfazer às necessidades dos consumidores.

Por outro lado, a análise de conversão deve iniciar-se com uma análise da situação da empresa em cada um dos recursos-chave, em comparação às empresas concorrentes, objetivando determinar como deve ser a situação de cada um dos tipos de recursos ou fatores de conversão importantes para análise e tomada de decisão.

\subsection{DEFINIÇÃO DA ESTRUTURA ORGANIZACIONAL OBJETO DO TRABALHO}

Segundo OLIVEIRA (2001), pode ser considerado três níveis de abrangência ou de amplitude quando do desenvolvimento e implementação da estrutura organizacional:

- Nível da empresa;

- Nível da UEN - Unidade Estratégica de negócios; 
- Nível da corporação.

Onde a UEN é definida como: "Unidade Estratégica de Negócio, é uma unidade ou divisão da empresa responsável para desenvolver uma ou mais AEN Áreas Estratégicas de Negócios", sendo que a AEN é definia como: "Área Estratégica de Negócio, é uma parte do segmento de mercado com a qual a empresa, por meio de suas UEN's, se relaciona de maneira estratégica, ou seja, de forma otimizada”. (OLIVEIRA, 2001, pp.136).

Esses níveis de abrangência estão respeitando uma premissa para o adequado desenvolvimento e implementação da estrutura organizacional, que é considerar todo o sistema, para não se perder a visão global da abordagem da estrutura organizacional.

\subsubsection{Nível de Abrangência da Empresa}

Nesse caso, o estudo e a análise da estrutura organizacional estão considerando toda a empresa, tenha ela um ou mais negócios em seu contexto de atuação no mercado.

\subsubsection{Nível de Abrangência da UEN - Unidade Estratégica de Negócio}

Nesse caso, a amplitude de análise da estrutura organizacional é realizada em termos de unidade estratégica de negócio, pois esta pode ser considerada como um sistema, assim como foi o caso anterior de uma empresa.

\subsubsection{Nível de Abrangência da Corporação}

Nesse caso, está sendo considerada a administração corporativa, a qual congrega mais de uma unidade estratégica de negócio. 
Considerar-se-á neste trabalho a definição básica de Unidade Estratégica de Negócio apresentada pela General Eletric, onde define-se que uma unidade de negócio é uma divisão, linha de produtos ou outro centro de lucro de uma empresa que produz e comercializa um conjunto bem definido de produtos e/ou serviços correlatos, serve um conjunto claramente definido de clientes, numa área geográfica razoavelmente bem delimitada, competindo com um conjunto bem definido de concorrentes.

Partindo da premissa de que este trabalho está sendo desenvolvido para um sistema organizacional com uma unidade central e várias unidades de negócios (Figura-2.4), pode-se perceber que uma empresa que possua este perfil pode estar organizada em suas UEN's de forma linear, funcional, staff-and-line, divisional, com base em projetos, matricial ou de alto desempenho (definido no item 2.1). A empresa pode ser de capital aberto ou fechado, pode fazer parte de uma Holding ou mesmo ter uma estrutura tipo Keiretsu.

Isto é possível porque a base de análise do sistema administrativo e de cálculo dos indicadores de posição econômica será feita através da utilização dos conceitos inerentes do modelo de Custeio Direto - que será apresentada no Capítulo 3. Portanto, o modelo poderá ser utilizado em qualquer tipo de empresa, de qualquer segmento da economia que se enquadre na estrutura apresentada na Figura -2.4, onde se possa implementar o modelo de Custeio Direto, podendo ser indústria ou serviço (por exemplo: autopeça, montadora, refinaria - com uma sede e várias unidades de produção; banco - com uma sede e várias agências; construtora - onde cada prédio pode ser considerado como uma UEN; loja de varejo ou atacado - onde cada ponto de venda pode ser uma UEN etc.)

Em muitos casos as UEN's, são também chamadas de Unidades Estratégicas de Operações, podendo estar subdividias em AEN's e/ou famílias de produtos e/ou linhas de produtos, quando vista segundo a forma de interação com o mercado. Portanto, como a proposta é trabalhar com indicadores de posição econômica interno à empresa, não serão consideradas daqui em diante as subdivisões de AEN ou de linhas de produtos. 
Abaixo (Figura-2.4) está apresentado o modelo básico que será utilizado neste trabalho, uma empresa com uma sede administrativa e suas unidades de negócios, onde cada produto de cada UEN pode ser vendido em vários mercados diferentes, geograficamente separados e para grupos diferentes de consumidores, alterando-se, portanto, os preços unitários e as despesas proporcionais ao faturamento.

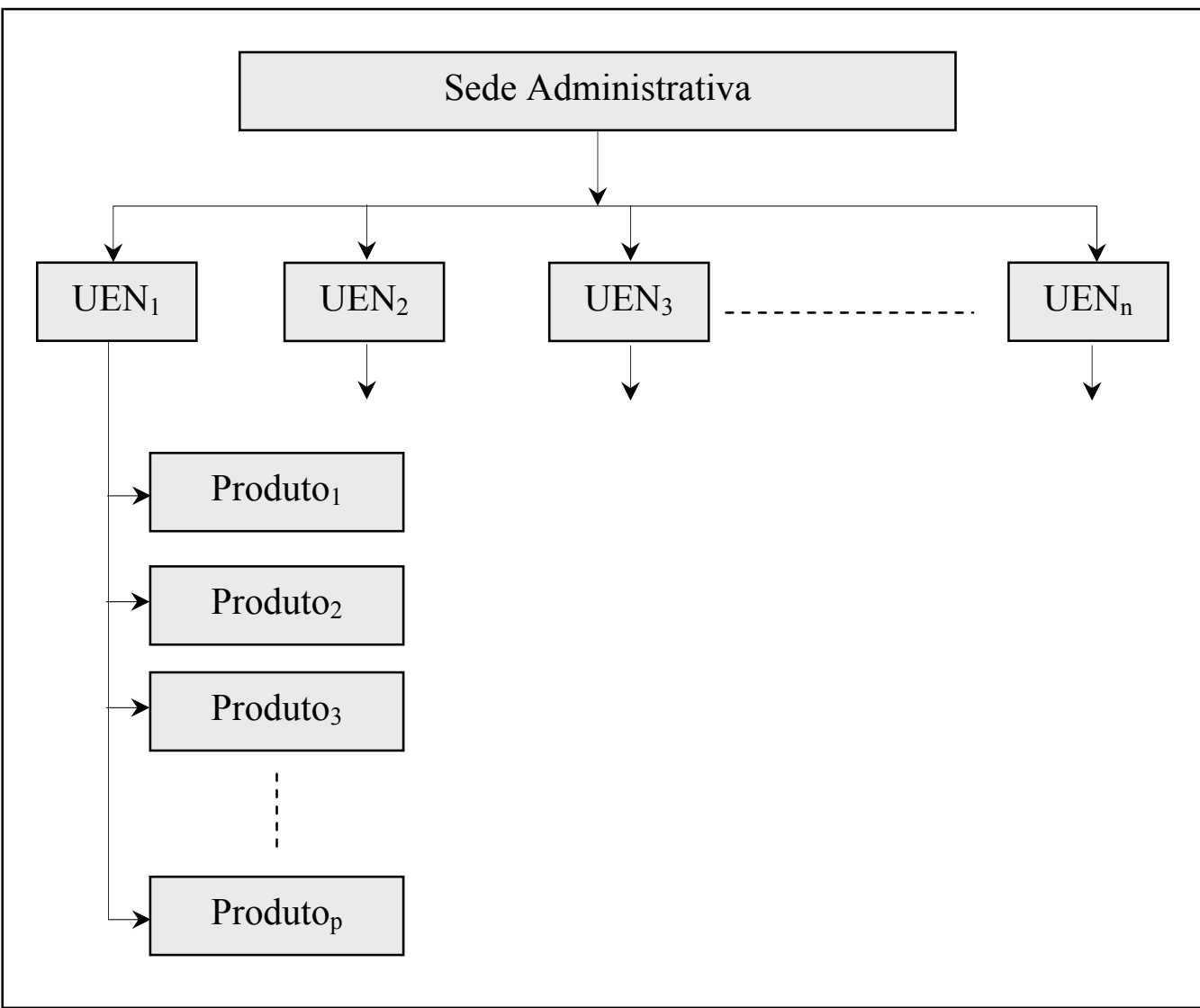

Figura 2.4 - Estrutura com uma unidade central e várias unidades de negócios. Por outro lado, o que pode variar de uma empresa para outra, além da estrutura de comando e a forma de trabalho, é o grau de dependência das UEN's (o que é centralizado na sede administrativa e o que é delegado para cada UEN), a autonomia de decisões de investimento, P\&D, estratégias de vendas, marketing etc. Essa variação pode afetar o processo de análise e de tomada de decisões em relação aos resultados obtidos, pois não altera a implementação e a utilização do modelo proposto nessa Tese.

Por exemplo, se o departamento de marketing for centralizado, todas as suas despesas estarão alocadas na sede administrativa e se, por outro lado, cada UEN possuir um departamento de marketing, estes estarão alocados como despesas fixas 
de cada UEN, alterando o valor de alguns indicadores e, portanto, a análise conjuntural, não afetando porém a utilização do modelo proposto.

Assim, como cada UEN tem seu próprio ambiente externo e interno que precisam ser avaliados, a modelagem do sistema através do modelo de custeio direto deverá levar em consideração tais variações sem perder o foco e o objetivo deste trabalho, criando a base de informações para a análise dos indicadores de posição econômica. 


\section{CUSTEIO DIRETO}

Como os indicadores de posição econômica (ver Capítulo 4) utilizados neste trabalho serão calculados a partir da base de informações criada pelo Custeio Direto, não será discutida qual metodologia de custos mais apropriada ou de melhor aplicabilidade a ser utilizada, sendo a aplicação do Custeio Direto uma premissa deste trabalho. Portanto, a seguir, será apresentada a definição e a descrição do modelo teórico do Custeio Direto, suas vantagens, suas desvantagens e aplicações, fazendo uma comparação com o Custeio por Absorção para melhor compreensão do modelo utilizado.

Segundo VANDERBECK (2001), no sistema de Custeio Direto, o custo de um produto manufaturado inclui apenas os custos que variam diretamente com o volume de produção: materiais diretos, mão-de-obra direta e custos indiretos de fabricação variáveis. Esse método também conhecido como Custeio Variável, porque apenas os custos variáveis de manufatura são atribuídos aos produtos, enquanto que os Custos Indiretos de Fabricação fixos são classificados como um custo de período e debitados totalmente no período no qual os custos fixos foram incorridos.

Portanto, os custos de período não são atribuídos aos produtos, mas são reconhecidos como despesas, alocados totalmente no período em que foram incorridos. Todos os custos que não variam com a produção podem ser considerados como custos de período - estes incluem despesas de vendas, despesas financeiras, despesas gerais e administrativas. Sendo que a única diferença entre o custeio direto e o custeio por absorção é a classificação dos Custos Indiretos de Fabricação Fixos (CIF fixos), sob o custeio direto, os CIF fixos são classificados como custos de período e, sob o custeio por absorção, são tratados como custos de produto.

Segundo BRUNSTEIN (1985), o modelo de custeamento direto está apoiado na correta alocação dos custos e despesas fixas próprias de um produto ou de uma atividade, sendo que a rentabilidade dos produtos é medida pela margem de contribuição e os custos e despesas estruturais são dispostos em bloco sem qualquer 
tipo de rateio. Portanto, o termo normalmente utilizado no custeio direto para designar a diferença entre vendas e o custo de produtos vendidos é a Margem de Contribuição.

BRUNSTEIN (1985) diz que os produtos vendidos no período propiciam receitas brutas iguais aos diferentes preços de venda unitário multiplicados pelas quantidades. Destas receitas brutas deve-se retirar aquelas despesas que ocorrem simultaneamente com o faturamento, e que a ele são proporcionais, como os impostos (IPI, ICMS, PIS, ISS, COFINS etc.), comissões de vendas, fretes, seguros, embalagens, royalties, algumas despesas financeiras etc., obtendo-se assim, a receita líquida do período. Supondo produtos vendidos para diversos locais, geograficamente separados, e para grupos diferentes de consumidores, alterando-se, portanto, os preços unitários e as despesas proporcionais ao faturamento, torna-se imprescindível calcular a receita líquida por produto em cada mercado.

Por outro lado, LEONE (1995) diz que custeamento direto ou variável é basicamente um sistema em que os custos são classificados do seguinte modo:

- Custos Fixos - não variam com o volume de atividade;

- Custos Variáveis - variam diretamente com o volume da atividade.

O autor complementa a definição acima dizendo que outra característica básica do sistema é aquela que diz respeito à maneira de se acumularem e se capitalizarem os custos. Segundo esse sistema, somente os custos variáveis de fabricação serão contabilizados no custo dos produtos fabricados. Os custos variáveis de administração e de vendas serão debitados diretamente ao custo dos produtos acabados e que vão ser vendidos. Os custos periódicos serão globalmente lançados contra os resultados obtidos no período. Esse procedimento oferecerá vantagens capitais ao administrador no processo de tomada de decisão, porque fornece explicitamente a medida da margem de contribuição.

Por fim, LEONE (1995) fala que pelo custeio direto, o lucro de um período não será afetado pela produção desse período. Por outro lado, ele ainda diz que se a produção for maior do que as vendas do período, o lucro será fortemente afetado, pois uma parcela dos custos periódicos será capitalizada como ativo realizável em 
forma de estoques, tal fato decorre do conceito que a direção da empresa faz do princípio contábil geralmente aceito, denominado princípio da coordenação contábil. Assim, a direção pode achar que todas as rendas de um dado período deverão ser comparadas com todos os custos do período, se essa for a filosofia básica, então ela utilizará o método do custeio por absorção. Todavia, se a administração entende que os custos de um período devem ser debitados contra as rendas desse mesmo período, sejam ou não as instalações utilizadas, então a ação será conduzida segundo as condições básicas do custeio direto.

\subsection{CUSTEIO POR ABSORÇÃO E O CUSTEIO DIRETO}

Segundo MARTINS (2001), Custeio por Absorção é o método derivado da aplicação dos princípios de contabilidade geralmente aceitos; consiste na apropriação de todos os custos de produção aos bens elaborados, e só os de produção; todos os gastos relativos ao esforço de fabricação são distribuídos para todos os produtos. Nesse método, se apropriam todos os custos de produção, quer fixos, quer variáveis, quer diretos ou indiretos, e tão somente os custos de produção são apropriados aos produtos elaborados.

O autor diz ainda que o Custeio por Absorção tem grande utilidade para fins gerenciais no uso de um valor em que existam custos fixos apropriados. Porém, grandes problemas podem ocorrer na utilização desse método:

- Por sua própria natureza, os custos fixos existem independentemente da fabricação ou não desta ou daquela unidade, e acabam presentes no mesmo montante, mesmo que oscilações (dentro de certos limites) ocorram no volume de produção; tendem os custos fixos a ser muito mais um encargo para que a empresa possa ter condições de produção do que sacrifício para fabricação específica desta ou daquela unidade; são necessários muito mais para que a indústria possa operar e ter instalada sua capacidade de produção, do que para fabricar uma unidade a mais de determinado produto. 
- Por não dizerem respeito a este ou aquele produto ou a esta ou aquela unidade, são quase sempre distribuídos à base de critérios de rateio, que contêm, em maior ou menor grau, arbitrariedade; quase sempre grandes graus de arbitrariedade. A maior parte das apropriações é feita em função de fatores de influência que, na verdade, não vinculam efetivamente cada custo a cada produto, porque essa vinculação é muito mais forçada do que costumamos acreditar. Se, a fim de avaliar um produto para efeito de estoque, isso pode ser uma forma de minimizar injustiças, para efeito de decisão simplesmente mais confunde do que auxilia; o fato de se apropriar de uma forma pode alocar mais custo e um produto do que em outro e, se alterarmos o critério de rateio, talvez façamos o inverso. Por se alterar um procedimento e distribuição de custos fixos, pode-se fazer de um produto rentável (aparentemente) ou transformar um superavitário em deficitário, e vice-versa. E não há lógica em se alterar o grau de rentabilidade de um produto em função de modificações nas formas de rateio; essa é uma maneira de se auto-enganar.

- O valor do custo fixo por unidade depende ainda do volume de produção: aumentando-se o volume, tem-se um menor custo fixo por unidade e viceversa. Ao se decidir com base em custo, é necessário associar sempre ao custo global o volume que se tomou como base. Se a empresa estiver reduzindo um item por ser pouco lucrativo, pior ainda ficará sua posição, devido à diminuição do volume; ou, se um produto estiver com baixo lucro, o aumento de preço com base em seu alto custo poderá provocar uma diminuição de sua procura e, conseqüentemente, reduzir seu volume, e assim aumentar ainda mais o custo de produção, num círculo vicioso. Pior do que tudo isso, o custo de um produto pode variar em função da alteração de volume de outro produto, e não da sua própria; ao se aumentar a quantidade dos outros bens elaborados, o montante a ser carregado para um determinado produto será diminuído, já que os custos fixos globais serão agora carregados mais para aquele item, cuja quantidade cresceu. $\mathrm{O}$ custo de um produto pode, então, variar em função não de seu volume, mas da quantidade dos outros bens fabricados. 
Por tudo isso, segundo MARTINS (2001), chegou-se ao ponto de indagar: se todas essas desvantagens e riscos existem em função da apropriação dos Custos Fixos aos produto e se são eles muito mais derivados da necessidade de se colocar em condições de operar uma fábrica muito pouco estando de fato vinculados a este ou aquele produto ou unidade e, além disso, se são na maioria, senão a totalidade, repetitivos a cada período, porque não se deixar de apropriá-los aos produtos, tratando-os como se fossem despesas, ou encargos de período - nasceu assim o custeio direto ou variável.

HORNGREEN (2004) diz que o Custeio por Absorção e o Custeio Direto diferem somente em um aspecto conceitual, ou seja, que o overhead fixo da manufatura é incluído nos Custos Inventariáveis quando do Custeio por Absorção, sendo excluído quando se usa o método do Custeio Direto.

Pode-se dizer então, que o sistema de Custeio Direto não aloca à produção os custos fixos de produção, considerando-os como custos de período, ao passo que o Custeio por Absorção exige a apropriação dos custos fixos de produção aos produtos, rateando-os aos mesmos segundo critérios de rateio adequado.

Neste sentido, a rentabilidade do produto, pelo sistema de Custeio Direto é expressa pela Margem de Contribuição, que responde pela cobertura das despesas fixas totais da empresa, ao passo que no Custeio por Absorção a rentabilidade é medida pelo Resultado Operacional. Em outras palavras, a Margem de Contribuição representa mais exatamente, sobre o plano econômico, o que se ganha ao fabricar e vender um determinado produto, exprimindo a rentabilidade real da operação.

\subsection{VANTAGENS E DESVANTAGENS DO CUSTEIO DIRETO}

Segundo HORNGREEN (2004), o método do Custeio Direto tem sido motivo de muita controvérsia ao longo do tempo entre os contadores, não tanto pela discordância a respeito da necessidade de delinear uma "fronteira" entre comportamentos dos Custos Fixos e Variáveis, mas porque uma questão permanece sobre sua propriedade teórica para utilização em relatórios externos. 
Neste sentido, os proponentes do Custeio Direto argumentam que a parte fixa do overhead da fábrica, está mais para a capacidade de produção do que para o ato de produzir algum produto específico. Já seus opositores alegam que inventários podem carregar uma componente de Custo Fixo porque tanto os Custos Fixos como os Variáveis são necessários para a produção dos bens e, portanto, ambos devem ser inventariáveis, independente de suas diferenças de comportamento.

Por outro lado, é necessário ter em mente que os partidários da abordagem de Margem de Contribuição não colocam os Custos Fixos como algo irrelevante, mas sim que a distinção entre o comportamento dos Custos Fixos e Variáveis é fundamental para a finalidade de subsidiar tomada de decisão.

Portanto, independente de quem esteja certo, consideraremos que são duas visões diferentes, podendo ou não, serem válidas em função do que se pretende fazer com a informação resultante.

\section{Vantagens Segundo LEONE (1995)}

- A margem de contribuição oferece meios para identificar os produtos, territórios, clientes e outros segmentos da empresa e da atividade que estão oferecendo maior rentabilidade. Os custos atribuídos a esses segmentos serão exatamente os custos que não podem ser reduzidos ou eliminados. A natureza especial dos custos variáveis oferece essa vantagem em termos de análise. Os custos periódicos, uma vez que não dependem do volume de atividade, poderão ser reestudados ou reestruturados.

- São mais lucrativos os segmentos do negócio ou da atividade que oferecem maior margem de contribuição. A margem de contribuição é aquela parcela de lucro que serve para dar cobertura aos custos periódicos.

- Facilidade de resposta as seguintes perguntas:

- Quais os produtos que devem ser mais vendidos a fim de se obter a combinação de vendas mais lucrativa?

- Quantas unidades precisam ser vendidas a fim de realizar o lucro planejado, em termos de produto, territórios ou outros segmentos de atividade? 
- Após uma redução ou aumento de preços de venda ou de despesas, quantas unidades precisarão ser negociadas para se manter o mesmo nível de lucros?

- A margem de lucro aumentará se eliminarmos um produto, um território ou um cliente?

- Até que ponto pode-se baixar o preço de vendas sem incorrer em perdas significativas?

- A administração deverá comprar ou fabricar peças componentes?

\section{Vantagens Segundo VANDERBECK (2001)}

- Fornece dados mais compreensíveis com relação aos custos, volumes, receitas e lucros para os membros da administração que não são formalmente treinados no campo da contabilidade.

- Apresenta dados de custos de forma que realça o relacionamento entre vendas e custos variáveis da produção, que se movimentam na mesma direção que as vendas.

- Apresenta um quadro mais claro de como as mudanças no volume da produção afetam os custos e a renda.

\section{Desvantagens Segundo LEONE (1995)}

- Há uma grande dificuldade em classificar corretamente os custos segundo o seu comportamento diante do volume de atividade, principalmente em relação aos custos semi-variáveis.

- A adoção do custeamento direto pode levar o administrador a relegar os custos periódicos no processo de estabelecimento dos preços de venda.

\section{Desvantagens Segundo VANDERBECK (2001)}

- Gera informações úteis somente para tomada de decisões internas, não sendo aceito no custeio de estoques para fins de relatórios externos, nem para imposto de renda e demonstrações financeiras.

- Na opinião dos oponentes, tanto os custos fixos quanto os variáveis são incorridos na manufatura de produtos, por isto devem ser levados em conta no custeamento do produto. 


\section{Vantagens da Margem de Contribuição ${ }^{2}$}

- A Margem de Contribuição sempre auxilia a gerência a decidir quais produtos trabalhar e quais aqueles que devem ser descontinuados ou tolerados, devido aos benefícios de vendas em relação a outros produtos. No curto prazo, se um produto cobre mais do que seus Custos Variáveis, ele está contribuindo para a cobertura das Despesas Fixas e para o lucro global.

- Margem de Contribuição pode ser utilizada para previsões de alternativas com relação à redução de preços, descontos especiais, campanhas promocionais especiais e utilização de prêmios para incentivar aumentos de volume de vendas. Decisões como essas são tomadas como resultado da comparação dos custos adicionais previstos, em relação às previsões adicionais resultantes de vendas.

- Quando são determinados os lucros desejados, as vendas necessárias para seu atingimento podem ser rapidamente calculadas, efetuando-se a divisão dos custos fixos mais os lucros desejados pela Margem de Contribuição unitária.

- A abordagem da Margem de Contribuição é útil quando os preços de venda forem ou estiverem firmemente estabelecidos no ramo industrial, uma vez que o principal problema para uma empresa individual é identificar: qual o Custo Variável admissível e qual volume podem ser obtidos?

- Os partidários da abordagem da Margem de Contribuição dizem que a compilação dos Custos Unitários dos produtos ajuda os gerentes a compreender os relacionamentos entre custos, volumes, preços e lucros, levando ainda a melhores decisões.

2 Tópico adaptado da Dissertação apresentada à Escola Politécnica da USP, em 1993 “Considerações sobre gestão competitiva de preços", por José Paulo Alves Fusco, pp. 71. 


\subsection{REPRESENTAÇÃO ESQUEMÁTICA DO MODELO ECONÔMICO DA EMPRESA ${ }^{3}$}

A apuração do resultado da empresa no período será obtida em uma conta análoga á da Apuração de Resultados da Contabilidade, com algumas adaptações. Do lado crédito, á direita da conta, colocam-se as MBC e MSBC. Desta forma, os valores aí registrados estarão depurados das DPF, dos custos e das despesas variáveis e dos custos e das despesas fixas próprias identificadas. Do lado débito, à esquerda, colocam-se os custos e as despesas fixas gerais comuns, que ainda não foram considerados.

$\mathrm{O}$ resultado operacional será obtido pela diferença entre as somas das $\mathrm{MBC}$ e MSBC de produtos e atividades e os custos e as despesas fixas gerais comuns. Se o resultado for positivo, obteremos lucro; este valor será registrado no lado do débito, à esquerda, abaixo dos custos e das despesas fixas gerais comuns.

Desta forma, a conta estará fechada e todos os valores numéricos relevantes estarão representados conforme apresentado no Figura 3.1 abaixo.

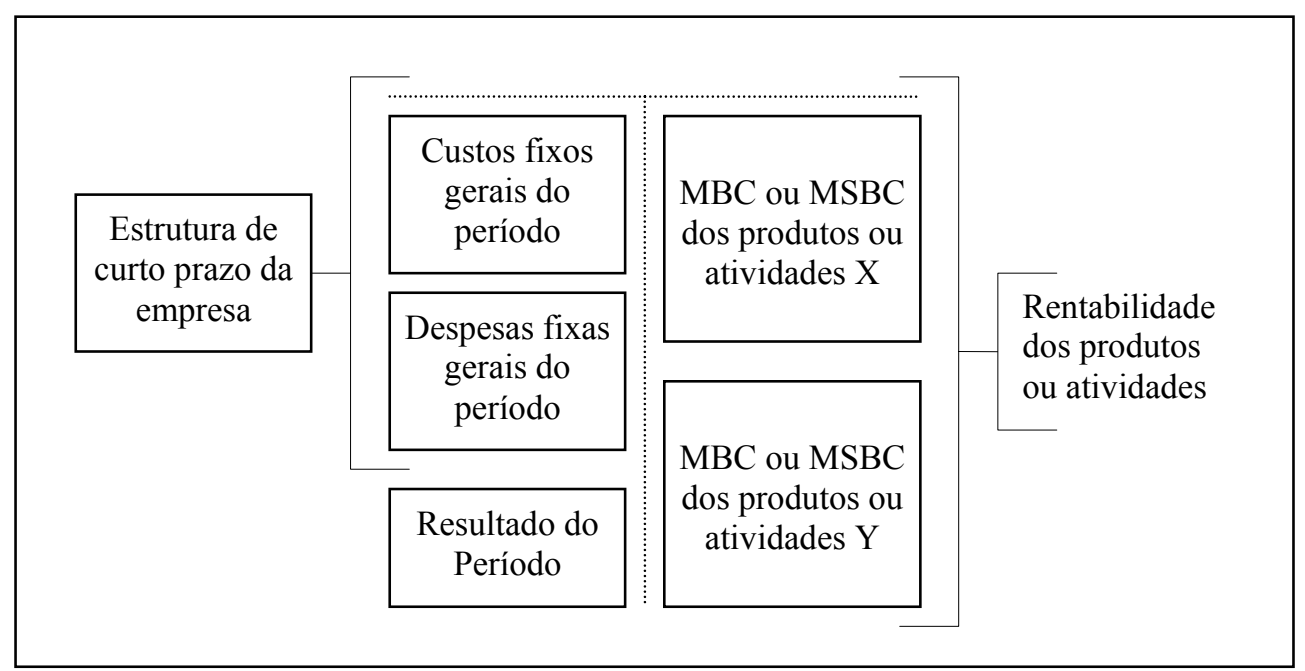

Figura 3.1 - Apuração do resultado do período. (BRUNSTEIN 2005, pp.9)

${ }^{3}$ Tópico adaptado do artigo "Programação econômica na empresa: um modelo descritivo de referência”, apresentado no VII Encontro Nacional de Engenharia de Produção em 1987 em Niterói por Israel Brunstein e do Livro "Economia de empresas: gestão econômica de negócios" do mesmo autor. 
Para simplificar a apresentação dos conceitos relevantes para a descrição do modelo econômico, vamos supor uma empresa manufatureira com apenas dois produtos que designaremos por $x$ e $y$. Durante um período de tempo definido, por exemplo, um mês, esta empresa tendo operado em condições normais, produziu e vendeu seus produtos, suportando certos custos e despesas que permaneceriam invariantes, qualquer que tivesse sido o volume realizado de operações. Estes custos e despesas representam para aquele período de tempo, a estrutura básica utilizada pela empresa para a condução de suas atividades de obtenção dos produtos e das receitas. Vamos denominar estes custos e despesas fixas estruturais de $C D F$.

Os produtos vendidos no período propiciam receitas brutas iguais aos diferentes preços de venda unitários multiplicados pelas quantidades. Destas receitas brutas deve-se retirar aquelas despesas que ocorrem simultaneamente com o faturamento, e que a ele são proporcionais, como os impostos (IPI, ICMS, PIS, ISS, COFINS etc.), comissões de vendas, fretes, seguros etc. Obtendo-se assim, a receita líquida do período. Supondo produtos vendidos para diversos locais, geograficamente separados, e para grupos diferentes de consumidores, alterando-se, portanto, os preços unitários e as despesas proporcionais ao faturamento, torna-se imprescindível calcular a receita líquida por produto em cada mercado.

Chamando:

$C V M_{x}-$ Custo variável médio do produto $x$

$C V M_{y}$ - Custo variável médio do produto $y$

$C V M u_{x i}$ - Custo variável médio unitário do produto $x$ no mercado $i$

$D P F_{x i}$ - Despesas proporcionais ao faturamento do produto $x$ no mercado $i$

$D P F_{y j}$ - Despesas proporcionais ao faturamento do produto $y$ no mercado $j$

$M B C_{x i}$ - Margem bruta de contribuição do produto $x$ no mercado $i$

$M B C_{y j}$ - Margem bruta de contribuição do produto $y$ no mercado $j$

$P_{x i}$ - Preço de venda do produto $x$ no mercado $i$

$P_{y j}$ - Preço de venda do produto $y$ no mercado $j$

$Q_{x i}$ - Quantidade faturada do produto $x$ no mercado $i$

$Q_{y j}$ - Quantidade faturada do produto $y$ no mercado $j$

$R B_{x i}$ - Receita bruta do produto $x$ no mercado $i$ 
$R B_{y j}$ - Receita bruta do produto $y$ no mercado $j$

$R L T_{x}$ - Receita líquida total do produto $x$

$R L T_{y}$ - Receita líquida total do produto $y$

$R L_{x i}$ - Receita líquida do produto $x$ no mercado $i$

$R L_{y j}$ - Receita líquida do produto $y$ no mercado $j$

$R P$ - Resultado do período

Todos estes valores referentes ao mesmo período de tempo têm-se:

$$
\begin{aligned}
& R L_{x i}=R B_{x i}-D P F_{x i} \\
& R L_{y j}=R B_{y j}-D P F_{y j} \\
& R B_{x i}=P_{x i} \cdot Q_{x i} \\
& R B_{y j}=P_{y j} \cdot Q_{y j}
\end{aligned}
$$

Se desejarmos:

$$
\begin{aligned}
& R L T_{x}=\sum_{i=1}^{m}\left(P_{x i} \cdot Q_{x i}-D P F_{x i}\right) \mathrm{e}, \\
& R L T_{y}=\sum_{i=1}^{n}\left(P_{y j} \cdot Q_{y j}-D P F_{y j}\right)
\end{aligned}
$$

Onde $m$ e $n$ representam, respectivamente o número de diferentes mercados onde $x$ e $y$ são vendidos.

Os produtos entregues em cada mercado, correspondem às quantidades faturadas, tiveram custos variáveis de produção correspondentes a $Q_{x i}$. $C V M_{x}$ e $Q_{y j}$. $C V M_{y}$, onde $C V M_{x}$ e $C V M_{y}$ são custos variáveis médios de $x$ e $y$.

A diferença entre $R L_{x i}$ e $Q_{x i} . C V M_{x}$ no mercado $i$ corresponde ao ganho econômico obtido no período gerado em $i$. Esta diferença é a Margem Bruta de Contribuição obtida no mercado $i$ com o produto $x$ no período, e pode ser representada por $M B C_{x i}$. Portanto,

$$
\begin{aligned}
& M B C_{x i}=R L_{x i}-Q_{x i} \cdot C V M_{x} \mathrm{e}, \\
& M B C_{x}=\sum_{i=1}^{m}\left(R L_{x i}-Q_{x i} \cdot C V M u_{x i}\right)
\end{aligned}
$$


Onde, $M B C_{x}$ é a margem Bruta de Contribuição Total do Produto $x$ no período. Esta Margem Bruta de Contribuição Total do Produto $x$ é a Rentabilidade do Produto $x$ durante aquele período de operações e equivale ao ganho econômico obtido com este produto. De fato, uma expansão ou redução da quantidade $Q_{x i}$ terá uma influência na $M B C_{x i}$ cujos reflexos sobre o resultado obtido no período serão medidos exatamente por esta variação.

Analogamente, a Rentabilidade do Produto $y$ será dada pela $M B C_{y}$. É extremamente significante para o modelo à existência de custos e/ou despesas que, embora fixos por período, estejam associados e identificados com uma atividade ou um produto. A colocação adequada destes custos ou despesas é fundamental para a análise econômica, como será visto adiante, em aplicação prática do modelo. Sendo estes custos e despesas fixas próprias, ou identificadas, uma responsabilidade direta da atividade ou produtos aos quais estão associados; eles devem ser subtraídos da margem bruta de contribuição, quando obtemos, então a Margem Semi-Bruta de Contribuição. Portanto, a partir deste conceito tem-se:

$$
M S B C_{x i}=M B C_{x i}-\mathrm{CDFP}_{x i}
$$

Onde $M S B C_{x i}$ é a Margem Semi-Bruta de Contribuição do Produto $x$ no mercado $i$ e $C D F P_{x i}$ são os Custos e/ou Despesas Fixas Próprias do Produto $x$ no mercado $i$ (caso do produto $x$ ser vendido no mercado $i$ através de show-room ou equivalente, por exemplo, ou do produto $x$ necessitar de tratamento especial para ser vendido no mercado $i$, representando $\mathrm{C} D F P_{x i}$ os custos fixos deste tratamento no período).

Caso o produto $x$ tenha custos e/ou despesas fixas próprias identificados, associados com sua produção ou venda, independente do mercado, tem-se:

$$
\mathrm{MSBC}_{\mathrm{x}}=\mathrm{MBC}_{\mathrm{x}}-\mathrm{CDFP}_{\mathrm{x}}
$$

Onde $\mathrm{MSBC}_{\mathrm{x}}$ é a Margem Semi-Bruta de Contribuição Total de $x$ no período e será, agora a medida de Rentabilidade do Produto $x$ naquele período.

Caso haja outros custos ou despesas fixas ou variáveis, não explicitados especificamente no que foi desenvolvido até o momento, terão um tratamento similar 
ao que foi visto, sendo as variáveis somadas aos custos variáveis e os fixos de natureza geral, comuns aos produtos, somados aos CDF.

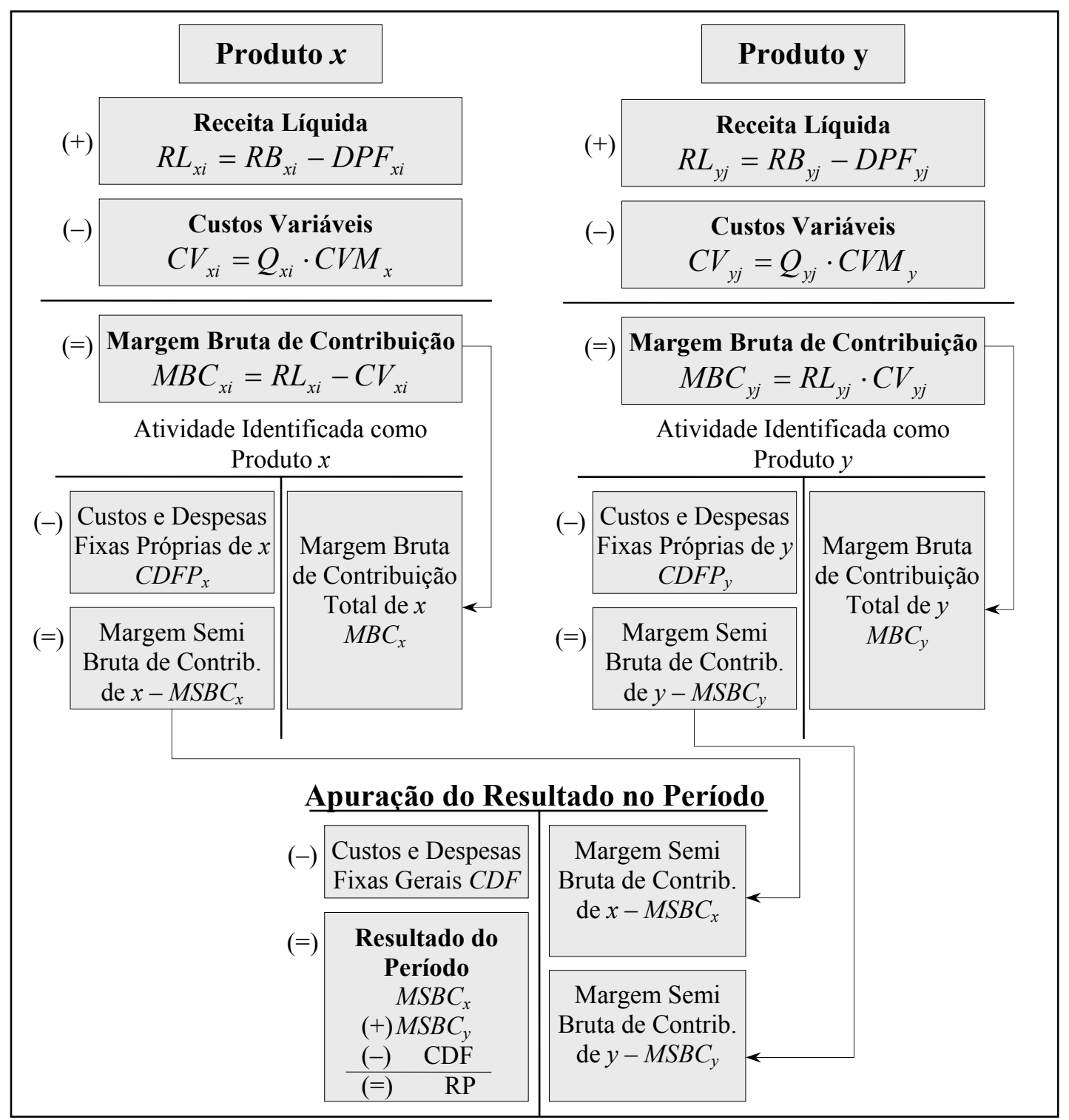

Figura 3.2 - Representação Esquemática do Modelo Econômico da Empresa.

(BUNSTEIN 2005, pp.10)

Chega-se, finalmente, ao ponto de se poder calcular o resultado do período. $\mathrm{O}$ valor obtido será o lucro econômico ou benefício líquido, se for considerado o custo de oportunidade do capital somado aos custos e despesas de estrutura. Assim, chamado de $R P$ o resultado do período, tem-se: 
$R P=\left(M S B C_{x}+M S B C_{y}\right)-\mathrm{CDF}$

Caso haja custos e despesas fixas próprias do produto, ou então:

$R P=\left(M B C_{x}+M B C_{y}\right)-\mathrm{CDF}$

Os conceitos até agora colocados e expressos em linguagem matemática podem ser representados, esquematicamente, como na Figura-3.2:

\subsection{ALGUMAS CONSIDERAÇÕES A RESPEITO DO CUSTEIO DIRETO}

As despesas proporcionais ao faturamento $(D P F)$, também chamada de despesas variáveis de venda, ocorrem independentemente dos custos de produção e são ligadas às vendas dos produtos, mais apropriadamente ao preço de venda dos produtos. Essas despesas, normalmente, são deduzidas da receita bruta (ou preço de venda), obtendo-se uma receita líquida (ou preço de venda líquido), deduzindo-se desta os custos variáveis de produção correspondentes ao volume vendido, a fim de se obter a Margem de Contribuição.

Se, ainda, o produto tiver custos fixos próprios, pode-se calcular a Margem Semi-Bruta de Contribuição subtraindo-os da Margem Bruta de Contribuição. Em certas circunstâncias, um produto pode exigir na planta industrial, uma seção ou grupo de máquinas voltadas unicamente para sua produção, assim como, certas despesas fixas de vendas são aplicadas diretamente ao mesmo (por exemplo: técnica especial de produção, canal de distribuição e venda particular etc.).

No caso em que haja toda uma linha de produção ou departamento produtivo que atenda a dois, três ou mais produtos, excluído-se os demais, os Custos de Despesas Fixas Próprias serão identificados com o grupo de produtos sem a necessidade de rateio. Em outros termos, os custos e as despesas fixas que não são de natureza geral devem ser pagos pela parcela de produtos ou atividades aos quais eles dão sustentação. 
Com esta metodologia, as despesas fixas próprias imputadas ao produto não resultam de uma distribuição arbitrária do total de despesas fixas, mas correspondem exatamente ao montante de despesas fixas ligadas diretamente à produção ou venda do produto considerado, e que desaparecerão caso o produto deixe de existir.

Para um produto vendido em diversos mercados, poderá ocorrer a existência de despesas fixas próprias a um produto em determinado mercado. Neste caso, deverá ser calculada a Margem Semi-Bruta de Contribuição para o produto no mercado específico.

A utilização da Margem de Contribuição responde a uma questão simples: qual resultado adicional nós teremos se produzirmos e vendermos um determinado volume de um produto? Esta mesma idéia pode ser expressa de maneira inversa, ou seja, qual será a redução no resultado se deixarmos de vender um certo volume de um determinado produto?

Neste sentido, BRUNSTEIN (2005), diz que a variação das vendas afeta diretamente a MBC, que afeta os ganhos obtidos pela empresa. Se não ocorrerem vendas do produto ou serviço no período, não haverá nenhuma geração de $\mathrm{MBC}$; logo, não haverá ganho algum.

O tratamento adequado dos custos e das despesas fixas identificados é essencial não só para a descrição do modelo econômico da empresa, como também para atender o mecanismo de relações econômicas presentes na empresa. Em cada caso deverá ser considerada a natureza específica dos produtos, serviços ou atividades para que o modelo econômico possa ser o mais representativo possível da realidade econômica da empresa.

\subsection{FORMULAÇÃO MATEMÁTICA PARA O MODELO ECONÔMICO PROPOSTO}

Para apresentar um modelo matemático, deve-se fazer algumas restrições objetivando delinear o problema. Portanto, durante um período de tempo definido, 
por exemplo, um mês, a empresa tendo operado em condições normais, produziu e vendeu seus produtos, suportando certos custos e despesas que permaneceriam invariantes, qualquer que tivesse sido o volume realizado de operações. Estes custos e despesas representaram para aquele período de tempo, a estrutura básica utilizada pela empresa para a condução de suas atividades de obtenção dos produtos e das receitas.

O modelo matemático proposto a seguir está apoiado no modelo de estrutura organizacional definido no Capítulo-2, no item 2.5, apresentado na Figura-2.4.

Inicialmente, para facilitar a operação e o desenvolvimento do modelo matemático do Custeio Direto, será considerado uma Unidade Estratégica de Negócios com produtos vendidos para diversos locais, geograficamente separados, e para grupos diferentes de consumidores, alterando-se, portanto, os preços unitários e as despesas proporcionais ao faturamento; torna-se imprescindível calcular a receita líquida por produto em cada mercado, podendo ser representado matematicamente da seguinte forma:

$R B_{i j}$ - Receita bruta do produto $i$ no mercado $j$

$P V_{i j}$ - Preço de venda do produto $i$ no mercado $j$

$P V L_{i j}$ - Preço de venda líquido do produto $i$ no mercado $j$

$Q_{i j}$ - Quantidade faturada do produto $i$ no mercado $j$

$D P F_{i j}$ - Despesas proporcionais ao faturamento do produto i no mercado $j$

$R L_{i j}$ - Receita líquida do produto $i$ no mercado $j$

$R L T_{i}-$ Receita líquida total do produto $i$

$R L T_{k^{-}}$- Receita líquida total da UEN $k$

$C D F_{i j}$ - Custos e despesas fixas próprio do produto $i$ no mercado $j$

$C D F_{i}-$ Custos e despesas fixas próprio do produto $i$

$C V M_{i}-$ Custo variável médio unitário do produto $i$

$C V_{i j}$ - Custo variável total do produto $i$ no mercado $j$

$C D F_{k}-$ Custos e despesas fixas comuns da UEN $k$ (custo de período)

$C D F_{\text {sede }}-$ Custos e despesas fixas comuns da sede administrativa

$R E S_{k}-$ Resultado da UEN $k$ (lucro antes do imposto de renda) 
$R E S_{\text {sede }}$ - Resultado da sede administrativa (lucro antes do imposto de renda)

$M B C u_{i j}$ - Margem bruta de contribuição unitária do produto $i$ no mercado $j$

$M B C_{i j}$ - Margem bruta de contribuição do produto $i$ no mercado $j$

$M B C_{i}$ - Margem bruta de contribuição do produto $i$

$M B C T_{k}$ - Margem bruta de contribuição total da UEN $k$

$M S B C_{i j}-$ Margem semi-bruta de contribuição do produto $i$ no mercado $j$

$M S B C_{i}$ - Margem semi-bruta de contribuição do produto $i$

$M S B C T_{k}$ - Margem semi-bruta de contribuição total da UEN $k$

$n$ - número total de diferentes mercados em que o produto i é vendido

$m$ - número total de produtos i vendidos

$p$ - número total de Unidade Estratégicas de Negócios de uma Empresa

$i$ - representa o produto

$j$ - representa o mercado onde o produto é vendido

$k$-representa a Unidade Estratégica de Negócio considerada

A formulação matemática apresentada a seguir foi desenvolvida por Unidade Estratégica de Negócio. A partir do cálculo do Resultado de cada UEN, será realizada a análise na Sede Administrativa e da empresa como um todo.

O cálculo da receita pode ser apresentado da seguinte forma:

$$
\begin{aligned}
& P V L_{i j}=P V_{i j}-D P F_{i j} \\
& R B_{i j}=P V_{i j} \cdot Q_{i j} \\
& R L_{i j}=P V L_{i j} \cdot Q_{i j}=\left(P V_{i j}-D P F_{i j}\right) \cdot Q_{i j} \\
& R L T_{i}=\sum_{j=1}^{n}\left(P V_{i j}-D P F_{i j}\right) \cdot Q_{i j} \\
& R L T_{k}=\sum_{i=1}^{m} R L T_{i}=\sum_{i=1}^{m} \sum_{j=1}^{n}\left(P V_{i j}-D P F_{i j}\right) \cdot Q_{i j}
\end{aligned}
$$

Desta forma, pode-se então calcular a margem bruta de contribuição de cada produto nos vários mercados em que estes produtos são comercializados:

$$
M B C u_{i j}=P V L_{i j}-C V_{i j}=P V_{i j}-D P F_{i j}-C V_{i j}
$$




$$
\begin{aligned}
& M B C_{i j}=M B C u_{i j} \cdot Q_{i j}=\left(P V_{i j}-D P F_{i j}-C V M_{i}\right) \cdot Q_{i j}, \text { ou } \\
& M B C_{i j}=R L_{i j}-C V M_{i} \cdot Q_{i j}=\left(P V_{i j}-D P F_{i j}-C V M_{i}\right) \cdot Q_{i j}
\end{aligned}
$$

Ainda, segundo BRUNSTEIN (1985), os produtos entregues em cada mercado, correspondentes às quantidades faturadas, tiveram custos variáveis de produção correspondentes a $Q_{i j} \cdot C V M_{i}$, sendo que a diferença entre $R L_{i j}-C V M_{i} \cdot Q_{i j}$ no mercado $j$ correspondente ao ganho econômico obtido no período gerado em $j$, sendo esta diferença a Margem Bruta de Contribuição obtida pelo produto $i$ no mercado $j$.

A equação abaixo representa a Margem Semi-Bruta de Contribuição do produto $i$ no mercado $j$, calculada quando o produto $i$ possui custos e/ou despesas próprias no mercado $j$; por exemplo: quando o produto $i$ é vendido no mercado $j$ através de um show-room próprio, ou necessite de um tratamento especial para ser vendido neste mercado, neste caso, a Margem Semi Bruta de Contribuição mede a renda econômica do produto $i$ no mercado $j$ para a empresa naquele período.

$$
M S B C_{i j}=M B C_{i j}-C D F_{i j}=\left(P V_{i j}-D P F_{i j}-C V M_{i}\right) \cdot Q_{i j}-C D F_{i j}
$$

Somando-se as $M S B C$ do produto $i$ em todos os mercados em que ele foi vendido, tem-se a Margem Semi-Bruta de Contribuição do produto $i$ no período. Esta margem de contribuição é a rentabilidade do produto $i$ durante aquele período de operações e equivale ao ganho econômico obtido com este produto em todos os mercados onde são vendidos. BRUNSTEIN ainda diz que uma expansão ou redução da quantidade $Q_{i j}$ terá uma influência na $M B C_{i j}$ cujos reflexos sobre o resultado obtido no período serão medidos exatamente por esta variação.

$$
M S B C_{i}=\sum_{j=1}^{n} M S B C_{i j}=\sum_{j=1}^{n}\left[\left(P V_{i j}-D P F_{i j}-C V M_{i}\right) \cdot Q_{i j}-C D F_{i j}\right]
$$

Por outro lado, a Margem Semi-Bruta de Contribuição Total do produto $i$ pode ser representada pela diferença entre a $M S B C$ do produto $i$ e os Custos Fixos Próprios do produto $i$, caso o produto $i$ possua algum custo próprio. Por exemplo: um gerente de fábrica específico em sua produção, independente do mercado em que ele será 
vendido. Neste caso, a Margem Semi-Bruta de Contribuição Total mede a renda econômica do produto $i$ para a empresa naquele período.

$$
\begin{aligned}
M S B C_{\text {Total }-i} & =\sum_{j=1}^{n} M S B C_{i j}-C D F_{i}=\sum_{j=1}^{n}\left[\left(P V_{i j}-D P F_{i j}-C V M_{i}\right) \cdot Q_{i j}-C D F_{i j}\right]-C D F_{i} \\
M S B C_{\text {Total }-i} & =\sum_{j=1}^{n}\left[\left(P V_{i j}-D P F_{i j}-C V M_{i}\right) \cdot Q_{i j}-C D F_{i j}\right]-C D F_{i}
\end{aligned}
$$

Então, pode-se calcular a Margem Semi-Bruta de Contribuição Total da empresa no período, somando-se as Margens Semi-Bruta de Contribuição Total de todos os produtos que a empresa comercializa. Para calcular o Resultado, ou o Lucro Econômico da empresa deve-se diminuir da MSBCT os custo e despesas fixas comuns da empresa, também chamados de custos de período, conforme apresentado abaixo:

$$
\begin{aligned}
& M_{S B C T_{k}}=\sum_{i=1}^{m} M S B C_{\text {Total }-i} \\
& M S B C T_{k}=\sum_{i=1}^{m}\left\{\sum_{j=1}^{n}\left[\left(P V_{i j}-D P F_{i j}-C V M_{i}\right) \cdot Q_{i j}-C D F_{i j}\right]-C D F_{i}\right\} \\
& R E S_{k}=M S B C T_{K}=M B C T_{k}-C D F_{k}
\end{aligned}
$$

Que também pode ser representado da seguinte forma:

$$
R E S_{k}=\sum_{i=1}^{m}\left\{\sum_{j=1}^{n}\left[\left(P V_{i j}-D P F_{i j}-C V M_{i}\right) \cdot Q_{i j}-C D F_{i j}\right]-C D F_{i}\right\}-C D F_{k}
$$

Agora, consideraremos uma empresa com sede administrativa com $p$ UEN's, onde o resultado de cada UEN pode ser calculado com a Equação-26, acima. Então, para análise da sede administrativa, o resultado de cada UEN torna-se a Margem Bruta de Contribuição capaz de cobrir as despesas fixas da sede administrativa, gerando o resultado global da empresa, conforme mostrado abaixo:

$$
R E S_{\text {sede }}=\sum_{k=1}^{p} M S B C T_{k}-C D F_{\text {sede }}
$$




\subsection{EXEMPLO NUMÉRICO}

O Exemplo que se segue objetiva apresentar a demonstração acima com valores numéricos, utilizando para apresentação da resolução a metodologia apresentada por BRUNSTEIN (1987) "Representação Esquemática do Modelo Econômico da Empresa", supondo uma UEN com apenas dois produtos vendidos em três mercados diferentes, com $\$ 15.000,00$ de Despesas Fixas Gerais, nas seguintes condições:

Tabela 3.1 - Dados referentes ao produto 1

\begin{tabular}{|l|c|c|c|c|}
\hline \multicolumn{1}{|c|}{ Mercados } & $P V_{1 j}$ & $D P F_{1 j}$ & $Q_{1 j}$ & $C D F_{1 j}$ \\
\hline Mercado 1 & 55,00 & 11,00 & 200 & 0 \\
\hline Mercado 2 & 53,00 & 9,00 & 350 & $4.000,00$ \\
\hline Mercado 3 & 54,00 & 8,00 & 180 & 500,00 \\
\hline $\begin{array}{l}\text { CVM } \\
\text { CD }=13,00 \\
C D F_{1}=3.000,00\end{array}$ \\
\hline
\end{tabular}

Tabela 3.2 - Dados referentes ao produto 2

\begin{tabular}{|l|c|c|c|c|}
\hline \multicolumn{1}{|c|}{ Mercados } & $P V_{2 j}$ & $D P F_{2 j}$ & $Q_{2 j}$ & $C D F_{2 j}$ \\
\hline Mercado 1 & 88,00 & 17,00 & 180 & 0 \\
\hline Mercado 2 & 86,00 & 15,00 & 110 & $4.500,00$ \\
\hline Mercado 3 & 86,00 & 14,00 & 230 & $1.200,00$ \\
\hline $\begin{array}{l}C V M_{2}=43,00 \\
C D F_{2}=2.000,00\end{array}$ \\
\hline
\end{tabular}

\section{Resolução}

Para resolução será utilizada a Representação Esquemática do Modelo Econômico da Empresa apresentada por BUNSTEIN (1987) na Figura-3.2.

Analisando-se as Margens de Contribuição unitárias, teremos a informação correta, ou seja, a qual produto dever ter incrementado suas vendas: 
Tabela 3.3 - Cálculo da Margem de Contribuição Untaria dos produtos para cada mercado

\begin{tabular}{|c|c|c|c|c|c|c|}
\hline \multirow{2}{*}{$\begin{array}{l}\text { Produtos } \\
\text { Itens }\end{array}$} & \multicolumn{3}{|c|}{ Produto 1} & \multicolumn{3}{|c|}{ Produto 2} \\
\hline & Mercado 1 & Mercado 2 & Mercado 3 & Mercado 1 & Mercado 2 & Mercado 3 \\
\hline$(+) P V_{i j}$ & 55,00 & 53,00 & 54,00 & 88,00 & 86,00 & 86,00 \\
\hline$(-) D P F_{i j}$ & $(11,00)$ & $(9,00)$ & $(8,00)$ & $(17,00)$ & $(15,00)$ & $(14,00)$ \\
\hline$(-) C V M_{i}$ & $(13,00)$ & $(13,00)$ & $(13,00)$ & $(43,00)$ & $(43,00)$ & $(43,00)$ \\
\hline $\begin{array}{l}(=) \\
M B C u_{i j}\end{array}$ & 31,00 & 31,00 & 33,00 & 28,00 & 28,00 & 29,00 \\
\hline
\end{tabular}

$\mathrm{Na}$ decisão sobre qual produto mereceria maior incentivo às vendas, a análise da margem de contribuição unitária oferece a condição necessária, segundo a ordem de classificação decrescente.

Portanto, analisando a Tabela-3.3, pode-se perceber que quanto mais Produto-1 for vendido, maior será a margem de contribuição global obtida e mais facilmente serão cobertos todos os custos e despesas fixas da empresa e, conseqüentemente, maior será o Resultado do Período, mesmo que este produto tenha um preço de venda menor do que o Produto-2. Isto se deve ao fato de que o Produto-1 colabora com uma Margem de Contribuição Unitária maior do que o Produto-2; mesmo assim, o esforço de venda deve ser feito para o Produto-1, no Mercado-3, pois é neste mercado onde a contribuição é maior.

Isto não nos leva a descartar, em primeira análise, quaisquer dos produtos em função da rentabilidade, pois todos apresentam Margem de Contribuição positiva, conferindo-nos, tão somente, uma idéia da rentabilidade apresentada e o poder de decisão quanto a vendas e estímulo de vendas.

Por outro lado, analisando a Figura-3.3 pode-se perceber que o Produto-2, no Mercado-2, apresenta uma Margem Semi Bruta de Contribuição negativa por causa do custo fixo próprio necessário para vendê-lo neste mercado. Então, como a Margem de Contribuição deste produto é positiva, deve-se estimular as vendas de modo a pagar este custo fixo, ou abandonar o Mercado-2 com este produto, se as vendas não atingirem pelo menos o ponto de equilíbrio neste mercado. 


\section{Produto 1}

(+)

\section{Receita Líquida}

$R L_{11}=(55-11) \cdot 200=8.800$

$R L_{12}=(53-9) \cdot 350=15 \cdot 400$

$R L_{13}=(54-8) .180=\underline{8.280}$

$R L_{I}=$

32.480

$(-)$

$$
\begin{gathered}
\text { Custos Variáveis } \\
C V_{11}=200.13=2.600 \\
C V_{12}=350.13=4.550 \\
C V_{13}=180.13=2.340
\end{gathered}
$$

(=) Margem Bruta de

\section{Contribuição}

$M B C_{11}=8.800-2.600=6.200$

$M B C_{12}=15.400-4.550=10.850$

\section{(-) Custos Fixos Próprios}

(=) M. Semi Bruta de Contribuição $M S B C_{11}=6.200-0=6.200$ $M S B C_{12}=10.850-4.000=6.850$ $M S B C_{13}=5.940-500=\quad 5.440$

$$
M B C_{1}=\mathbf{1 8 . 4 9 0}
$$

Atividade Identificada como Produto 1

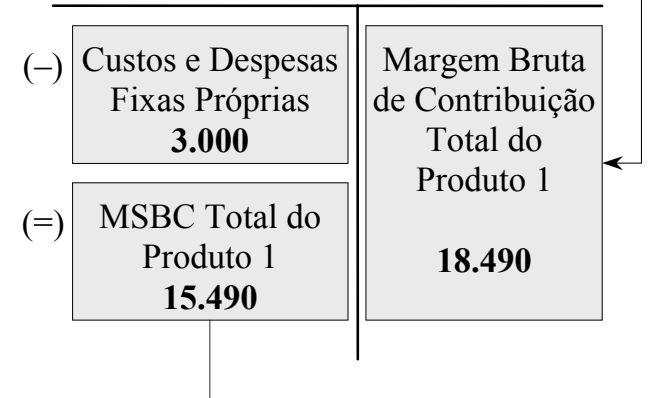

\section{Produto 2}

(+)

\section{Receita Líquida}

$R L_{2 l}=(88-17) .180=12.780$

$R L_{22}=(86-15) .110=7.810$

$R L_{23}=(86-14) .230=\underline{16.560}$

$\boldsymbol{R} \boldsymbol{L}_{2}=$

37.150

(-) Custos Variáveis

$C V_{2 I}=180.43=7.740$

$C V_{22}=110.43=4.730$

$C V_{23}=230.43=9.890$

(=) Margem Bruta de

Contribuição

$M B C_{21}=12.780-7.740=5.040$

$M B C_{22}=7.810-4.730=3.080$

\section{(-) Custos Fixos Próprios}

(=) M. Semi Bruta de Contribuição $M S B C_{21}=5.040-0=5.040$ $M S B C_{22}=3.080-4.500=(1.420)$ $M S B C_{23}=6.670-1.200=5.470$

$M B C_{2}=\mathbf{9 . 0 9 0}$

Atividade Identificada como Produto 2

(-) Custos e Despesas Margem Bruta Fixas Próprias de Contribuição 2.000

(=) MSBC Total do Produto 2 7.090 Total do Produto 2

\section{Apuração do Resultado no Período}

(-) Custos e Despesas Fixas Gerais $C D F$

\begin{tabular}{c} 
Resultado do \\
Período \\
15.490 \\
$(+) 7.090$ \\
$(-) 15.000$ \\
\hline (=) 7.580
\end{tabular}

Margem Semi Bruta de Contrib. do Produto 1 15.490

Margem Semi Bruta de Contrib. do Produto 2 7.090

Figura 3.3 - Resolução do Exemplo-3.1, utilizando Representação Esquemática do Modelo Econômico. 
Dado que $M S B C_{22}<0$, para valer a pena vender o Produto-2 no Mercado-2, é necessário vender pelo menos 161 produtos, para que sua margem de contribuição total possa cobrir os custos e despesas fixas próprias necessárias para vendê-lo neste mercado, sendo, portanto, o ponto de equilíbrio. Isto é, se for vendido menos de 161 produtos, a margem semi-bruta de contribuição seria negativa, e o produto estaria contribuindo negativamente para cobrir os custos e despesas fixas da UEN; se fosse vendido 161 produtos ou mais, o efeito seria o inverso. A definição e limitações da análise do ponto de equilíbrio serão discutidas amplamente no próximo capítulo, como ferramenta de tomada de decisões e, neste caso, podendo ser calculada da seguinte forma:

$$
Q e_{22}=\frac{C D F_{22}}{P V_{22}-D P F_{22}-C V M_{2}}=\frac{4.500}{86-15-43}=161 \text { produtos }
$$

Onde $Q e_{22}$ é a quantidade de equilíbrio de produtos vendidos do Produto-2 no Mercado-2.

Analisando ainda a Figura 3.3, pode-se perceber que o Produto-1, através da Margem Semi-Bruta de Contribuição, contribui mais do que o Produto-2 para pagar os custos e despesas fixas gerais da UEN, sendo responsável por 56\% da Margem Semi-Bruta de Contribuição total gerada, capaz de pagar os custos e as despesas fixas da UEN, gerando um Resultado do Período positivo, conforme apresentado. 


\section{INDICADORES DE POSIÇÃO ECONÔMICA}

O modelo econômico de uma empresa e/ou de seus subsistemas pode ser representado pela disposição das receitas, custos fixos e variáveis, custos e despesas identificadas com atividades ou produtos e despesas fixas gerais, de tal forma que a análise econômica da situação em estudo torna-se um elemento chave no estudo da rentabilidade dos produtos. Por outro lado, pode-se quantificar os efeitos de possíveis modificações a serem introduzidas em todos os subsistemas da empresa, auxiliando a tomada de decisão com riscos reduzidos.

As variações nos volumes de venda dos produtos afetam diretamente as MBCs e, consequentemente, o resultado da empresa como um todo. Particularmente, é de grande interesse no estudo do modelo econômico a forma como as margens brutas e semi-brutas são afetadas, e o modo como o resultado varia em função de alterações na quantidade vendida de um produto.

Segundo BRUNSTEIN (1987), a análise econômica da empresa pressupõe estudos sobre a obtenção e interpretação de dados do ambiente externo e interno da empresa, tais como estudos de mercado, pesquisa e coleta da estrutura de custos, das condições internas de operações e das políticas relacionadas à produção, estocagem, investimentos e preços. Quando estes estudos se referem a um período passado, temse um resultado que pode ser considerado satisfatório ou não. Como este resultado foi obtido e o que podemos fazer para conservá-lo ou buscar melhorias para o futuro é essencial para os estudos econômicos da empresa.

Para tanto, o cálculo dos indicadores de posição econômica (ponto de equilíbrio, margem de segurança, grau de alavancagem operacional e do grau de alavancagem combinado) torna-se muito importante no âmbito da quantificação da posição econômica da empresa, medindo o impacto dos subsistemas em sua situação econômica através da análise das posições econômicas relevantes e diferenciadas. $\mathrm{O}$ cálculo dos indicadores está baseado nos fundamentos do custeio direto e na correta alocação dos custos e despesas fixas próprias de um produto ou de uma atividade, conforme descrito no Capítulo-3. 


\subsection{PONTO DE EQUILÍBRIO (BREAK-EVEN POINT)}

Segundo SCHWEITZR (1986), 0 ponto de equilíbrio (também chamado de ponto de ruptura, ponto de nivelamento, ponto crítico ou break-even point) nasce da conjugação dos Custos Totais com as Receitas Totais, sendo que a receita apresenta um efeito positivo e os custos um efeito negativo em sua análise.

Segundo VANDEBECK (2001), o ponto de equilíbrio pode ser definido como o ponto no qual a receita de vendas é adequada para cobrir todos os custos e despesas sem obter lucro.

Neste trabalho será tratado somente a "análise de equilíbrio do contador", que é simplesmente o conjunto das aproximações lineares das curvas de custo e receita da "análise do economista". Para esta premissa, deve ser considerado um Intervalo de Significância em um horizonte de planejamento curto, minimizando o problema da linearização das curvas de receita, custos e lucro da empresa.

Segundo BORNIA (1987), o Intervalo de Significância é um intervalo onde o comportamento dos custos e despesas fixas e variáveis seguem aproximadamente os pressupostos, ou seja, são lineares (os fixos são constantes e os variáveis crescem com a produção). $\mathrm{O}$ autor ainda diz que não há na literatura nenhum procedimento teórico para encontrar este intervalo. A solução adotada é de delimitá-lo numa pequena região em torno do nível de atividades normal da empresa.

Portanto, devido a estas limitações, a análise de custo-volume-lucro é feita para o curto prazo, devendo-se reconsiderar os cálculos com certa freqüência. Para o médio e longo prazo, ela fornece apenas a tendência do comportamento dos custos da empresa. Porém, esta tendência é mais útil do que a total falta de informações desde que se tenha em mente suas restrições.

Por outro lado, a análise das relações custo-volume-lucro consiste basicamente em examinar as relações entre as mudanças no volume de produção ou de vendas de uma empresa e as alterações nos lucros. Essa análise está voltada para a tomada de decisões por parte do administrador. Em todas as decisões baseadas na relação custovolume-lucro parte-se da suposição fundamental de que a empresa possui um 
conjunto de recursos que gera um determinado montante de custos fixos a cada período. O administrador deve então, decidir sobre o melhor nível ou o melhor mix de produção de modo a maximizar o resultado da empresa (DOPUCH et all, 1974 apud CORRAR, 1990).

Segundo CORRAR (1990), a análise custo/volume/lucro objetiva principalmente determinar o nível de produção de uma empresa com um único produto ou ainda, o melhor mix de produção de uma empresa com multiprodutos. As decisões, por sua vez, se baseiam na simples relação entre as mudanças no lucro e as alterações no nível de produção ou no mix de produção. Os volumes e/ou mix de produção deverão ser alterados quando as receitas incrementais decorrentes dessas alterações excederem os custos incrementais de efetuar a mudança.

Na verdade, a empresa começa com um nível de produção zero com um prejuízo igual ao valor dos custos fixos. À medida que os produtos vão sendo vendidos, os prejuízos são reduzidos e, após, são transformados em lucros (depois de atingido o ponto de equilíbrio - ver Figura 4.1). Este lucro aumenta na proporção da margem de contribuição por unidade vendida.

De forma resumida, conforme apresentado por BRUSTEIN (2005), pode-se dizer que o ponto de equilíbrio pode ser estudado para um produto com relação aos seus custos fixos próprios, para um produto único de uma empresa ou de uma fábrica da empresa, considerando todos os seus custos e despesas fixas, ou para atividades parciais ou totais de uma empresa envolvendo mais de um produto. Neste último caso, a condição do ponto de equilíbrio passa a depender de hipóteses assumidas sobre a participação relativa dos vários produtos. Estas hipóteses podem ser dispensadas quando existe uma correlação entre as demandas dos produtos, como no caso de produtos complementares cuja proporção de vendas seja bastante estável, ou quando existe uma unidade de medida que resuma satisfatoriamente as proporções de participação dos produtos. 


\subsubsection{Análise de Ponto de Equilíbrio Considerando Um Produto}

No modelo básico de cálculo de Ponto de Equilíbrio, considera-se que tanto os custos como a receita total comportam-se de forma linear, e a modelagem é realizada considerando-se a produção e comercialização de apenas um produto. Neste caso, somente uma simples variável independente é empregada (para este caso será considerado o componente $i$ somente para padronizar a linguagem em todo o trabalho, porque considerar-se-á somente um produto; para todo o modelo básico tem-se que $i=1$ ). Considerar-se-á ainda, para facilitar a análise, que o produto é vendido em apenas um mercado e, inicialmente, não há diferença entre receita bruta e líquida.

Para ser mais preciso, segundo SCHWEITZR (1986), $Q$ pode ser definido como o nível de output ou, em algumas circunstâncias, como número de horas trabalhadas, de um centro de produção, de uma máquina ou de um modo geral de um departamento (manufatura convergente - quando a empresa produz um único produto utilizando-se de várias matérias-primas). Outra possibilidade é a utilização de uma matéria-prima principal como medida para avaliação de produção, no caso de empresas onde uma matéria-prima principal é utilizada na produção de vários produtos (manufatura divergente). Por exemplo, na indústria metal-mecânica, onde em várias empresas a matéria-prima principal é o aço, que processado pode produzir inúmeros produtos - portanto, neste caso pode-se trabalhar o ponto de equilíbrio em relação ao aço processado. Em todos os casos, a aplicação deve satisfazer as particularidades em relação à produção de cada firma.

Nesta aplicação em particular, os custos totais podem ser divididos em custos fixos e custos variáveis, sendo que o ponto de equilíbrio pode ser determinado matematicamente como segue:

$$
\begin{aligned}
& R=P_{i} \cdot Q_{i} \quad \mathrm{i}=1 \text { para todos os casos. } \\
& C T=C V_{i} \cdot Q_{i}+C D F
\end{aligned}
$$

Como o Ponto de Equilíbrio de uma empresa ocorre quando a Receita se iguala aos Custos, temos: 
$R=C T \Rightarrow P_{i} \cdot Q e_{i}=C V_{i} \cdot Q e_{i}+C D F \Rightarrow Q e_{i} \cdot\left(P_{i}-C V_{i}\right)=C D F$

$Q e_{i}=\frac{C D F}{P_{i}-C V_{i}}=\frac{C D F}{M C u_{i}}=\frac{C D F}{P_{1}-C V_{1}}=\frac{C D F}{M C u_{1}}$

onde: $M C u_{i}=P_{i}-C V_{i}$

$$
M C=\left(P_{i}-C V_{i}\right) \cdot Q_{i}
$$

Portanto, pode-se calcular o Lucro Bruto (ou o prejuízo) da seguinte forma:

$L B=R-C T=P_{i} \cdot Q_{i}-C V_{i} \cdot Q_{i}-C D F=M C-C D F$

$R$ - Receita

$L B$ - Lucro Bruto

$C T$ - Custo Total

$C D F-$ Custos e Despesas Fixas

$C V_{i}-$ Custo variável do Produto $i$

$P_{i}-$ Preço de Venda do Produto $i$

$Q_{i}$ - Quantidade Produzida do Produto $i$

$Q e_{i}-$ Quantidade de Equilíbrio

$M C u_{i}$ - Margem de Contribuição Unitária do Produto $i$

$M C$ - Margem de Contribuição Total

Para ilustração e apresentação gráfica do problema em questão, será introduzido um exemplo numérico para melhor visualização/compreensão. Por exemplo, considerando que o componente custo fixo seja de $\$ 60.000$, custo variável de $\$ 12$ por unidade e o preço de venda igual a \$20 por unidade, teremos através da Equação-31 o ponto de equilíbrio na ordem de 7.500 unidades com uma receita respectiva de $\$ 150.000$, que está apresentada através da equação abaixo e na Figura4.1 .

$$
Q e_{1}=\frac{C F}{P_{i}-C V_{i}}=\frac{60.000}{20-12}=7.500 \text { unidades }
$$




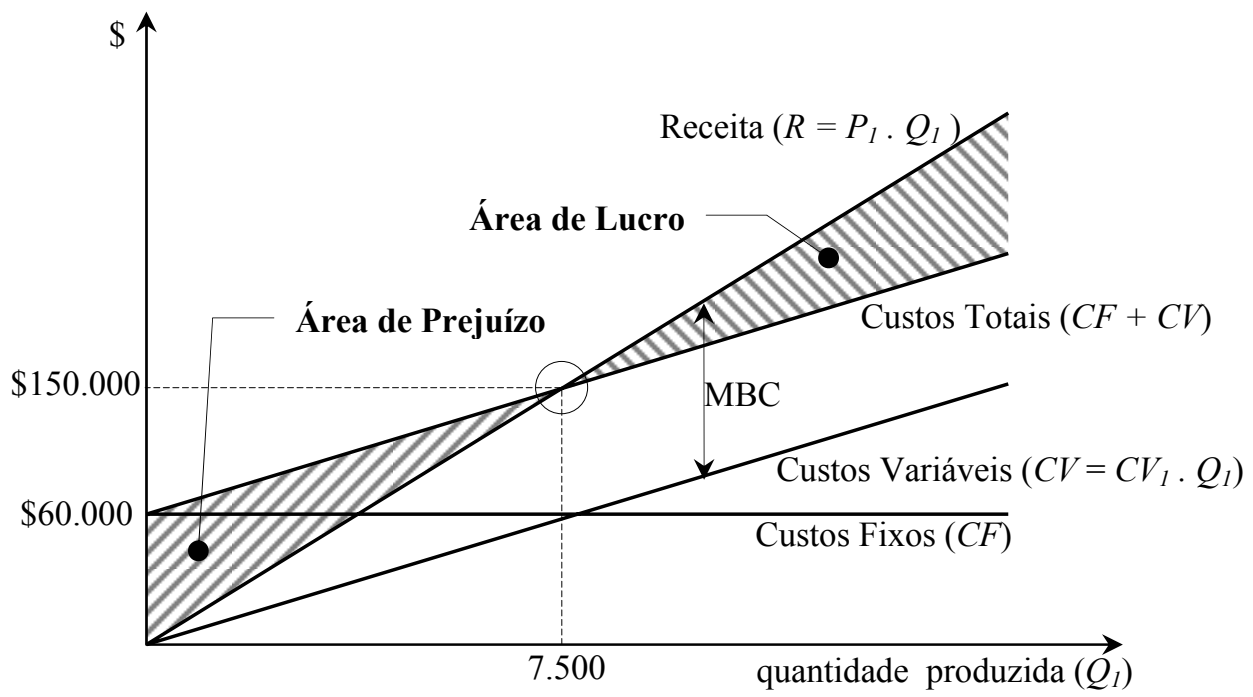

Figura 4.1 - Ponto de Equilíbrio.

Este é um gráfico representativo das relações Custo/Volume/Lucro que sumariza a diferença entre preços de venda e custos totais por unidade, de maneira que pode ser visualizado o impacto da mudança dos níveis de produção sobre os lucros.

Como se está trabalhando com funções lineares, basta conhecer dois pontos que pertençam a essa reta para determiná-la. Conectando-se dois pontos e estendendo-se a linha, pode-se determinar a Área de Prejuízo e a Área de Lucro, sendo que o aumento (ou redução) do lucro na Figura-4.1 pode ser calculado somando (ou diminuindo) a margem de contribuição por cada unidade vendida a mais (ou a menos).

Portanto, analisando a Figura-4.1, pode-se concluir que para um volume de produção menor que $Q e$ (7.500 unidades - ponto de equilíbrio), a empresa estará operando em prejuízo porque os custos excedem a receita, por outro lado para um volume de produção maior que $Q e$ a empresa estará operando com lucro, porque, a partir deste ponto, a receita é maior do que seus custos totais. Se a empresa não produzir, no caso em que $Q=0$, o prejuízo será igual aos custos fixos. Com o aumento do nível de produção a empresa irá reduzir gradativamente este prejuízo, 
sendo que para uma produção de 7.500 unidades não terá lucro nem prejuízo e, a partir deste ponto, a empresa passa a ter lucro.

Por outro lado, pode-se apresentar o mesmo gráfico com análise da margem de contribuição (Figura-4.2), onde a receita total e os custos totais não são explícitos, e a idéia principal é comparar o montante de custos fixos com a Margem de Contribuição, que é apresentada como uma função linear do volume de produção. Neste caso o valor da Margem de Contribuição de cada produto pode ser calculada conforme a Equação-33, como segue:

$$
M C_{i}=P_{i}-C V_{i}=20-12=\$ 8,00
$$

Então, para um nível de produção de 7.500 unidades, a Margem de Contribuição Total se iguala aos Custos Fixos da empresa, gerando lucro zero, como segue:

$$
\begin{aligned}
& M C=\left(P_{i}-C V_{i}\right) \cdot Q_{i}=(20-12) \times 7.500=\$ 60.000,00 \\
& L B=R-C T=P_{i} \cdot Q_{i}-C V_{i} \cdot Q_{i}-C F=20 \times 7.500-12 \times 7.500-60.000=0
\end{aligned}
$$

Então, no intuito de provar numericamente que a partir deste ponto o crescimento marginal do lucro é igual a Margem de Contribuição unitária do produto vendido, temos que para uma produção de 7.501 unidades o Lucro Bruto será acrescido da Margem de Contribuição unitária $(\$ 8,00)$, como segue:

$$
L B=R-C T=P_{i} \cdot Q_{i}-C V_{i} \cdot Q_{i}-C F=20 \times 7.501-12 \times 7.501-60.000=8
$$

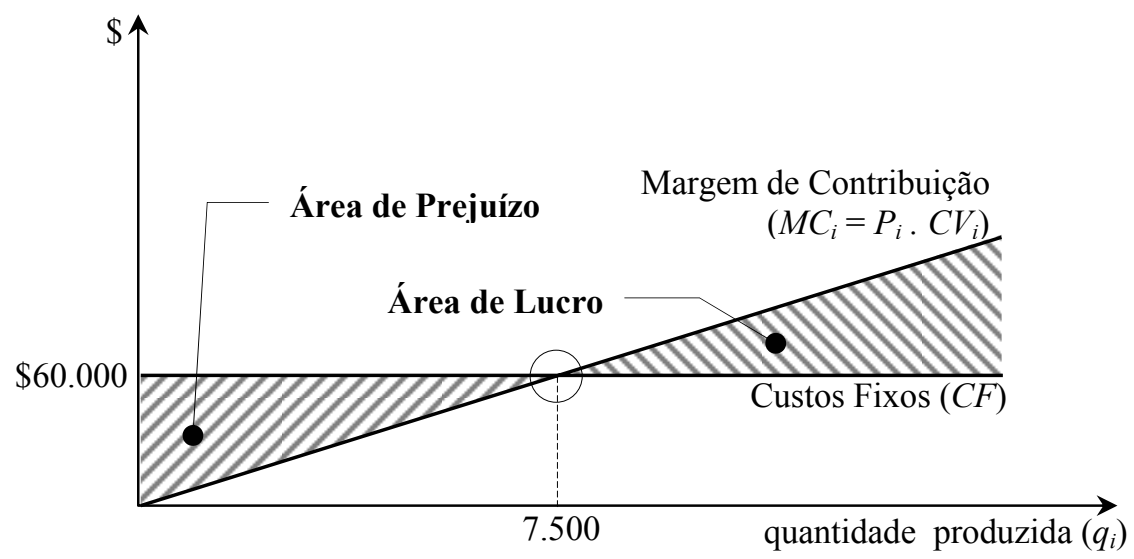

Figura 4.2 - Ponto de Equilíbrio - análise da Margem de Contribuição. 
Ainda, para o modelo básico, pode-se analisar o efeito dos impostos incidentes na receita (ou preço de venda) e nos lucros da empresa, mudando assim, o posicionamento do ponto de equilíbrio, bem como sua análise, podendo ser determinado como segue:

$R B=P_{i} \cdot Q_{i}$

como $\mathrm{i}=1$ para todos os casos, temos que:

$R B=P_{1} \cdot Q_{1}$

$R L=R B-D=P_{1} \cdot Q_{1}-D P F=P_{1} \cdot Q_{1}-P_{1} \cdot Q_{1} \cdot d_{1}$

$C T=C V_{1} \cdot Q_{1}+C F$

Onde:

$D_{P F}$ - Despesas Proporcionais ao Faturamento (impostos incidentes sobre a receita, comissões, fretes, seguros etc.)

$d_{i}-$ Despesas Proporcionais ao Faturamento do produto i - valores percentuais (impostos incidentes sobre a receita, comissões, fretes, seguros etc.)

$$
\begin{aligned}
& R B \text { - Receita Bruta } \\
& R L \text { - Receita Líquida }
\end{aligned}
$$

Como o Ponto de Equilíbrio de uma empresa ocorre quando a Receita se iguala aos Custos, temos:

$$
\begin{aligned}
& R L=C T \Rightarrow P_{1} \cdot Q e_{1}-P_{1} \cdot Q e_{1} \cdot d_{1}=C V_{1} \cdot Q e_{1}+C F \\
& \Rightarrow Q e_{1} \cdot\left(P_{1}-P_{1} \cdot d_{1}-C V_{i}\right)=C F \\
& Q e_{i}=\frac{C F}{P_{1}\left(1-d_{1}\right)-C V_{1}}=\frac{C F}{M C_{1}} \\
& \text { onde: } \quad M C_{1}=P_{1} \cdot\left(1-d_{1}\right)-C V_{1} \\
& \quad M C=\left[P_{1} \cdot\left(1-d_{1}\right)-C V_{1}\right] \cdot Q_{1}
\end{aligned}
$$


A partir do ponto de equilíbrio, o lucro da empresa poderá ser calculado a partir da equação abaixo (ver Figura 4.3), onde a provisão de imposto de renda é calculada sobre o lucro bruto, em linguagem contábil, sobre o Lucro Antes dos Juros e Imposto de Renda, e não sobre o lucro real.

$$
\begin{aligned}
& L B=R L-C T=P_{1} \cdot Q_{1}\left(1-d_{1}\right)-C V_{1} \cdot Q_{1} \cdot-C F \\
& L L=R L-C T-I R=R L-C T-L L \cdot i r=(R L-C T) \cdot(1-i r)
\end{aligned}
$$

Portanto, substituindo as equações, teremos:

$$
L L=\left[P_{1} \cdot Q_{1}\left(1-d_{1}\right)-C V_{1} \cdot Q_{1} \cdot-C F\right] \cdot(1-i r)
$$

onde:

$$
\begin{aligned}
& L L \text { - Lucro Líquido } \\
& I R \text { - Imposto de Renda (unidades monetárias) } \\
& I r \text { - imposto de renda em valores percentuais }
\end{aligned}
$$

Por exemplo, considerando o mesmo exemplo anterior, onde o componente custo fixo é de $\$ 60.000$, custo variável de $\$ 12$ por unidade e o preço de venda igual a $\$ 20$ por unidade, onde o ponto de equilíbrio era na ordem de 7.500 unidades com uma receita respectiva de $\$ 150.000$; se introduzirmos $15 \%$ de impostos sobre o faturamento $\left(d_{i}\right)$ da empresa, tal ponto de equilíbrio aumenta para 12.000 unidades com um faturamento bruto de $\$ 240.000$ e um faturamento líquido de $\$ 204.000$, conforme apresentado na Figura-4.3.

$$
Q e_{i}=\frac{C F}{P_{1}\left(1-d_{1}\right)-C V_{1}}=\frac{60.000}{20 \cdot(1-0,15)-12}=12.000 \text { unidades }
$$

Comparando a Figura-4.3 apresentado abaixo, com a Figura -4.1, pode-se concluir que as despesas proporcionais ao faturamento alteram o ponto de equilíbrio de uma empresa, sendo, então, de grande importância para tomada de decisões econômicas; neste caso, o ponto de equilíbrio foi aumentado em 4.500 unidades. Esta análise mostra que se as informações básicas do modelo não forem identificadas corretamente, os resultados poderão ser distorcidos levando a decisões equivocadas. 


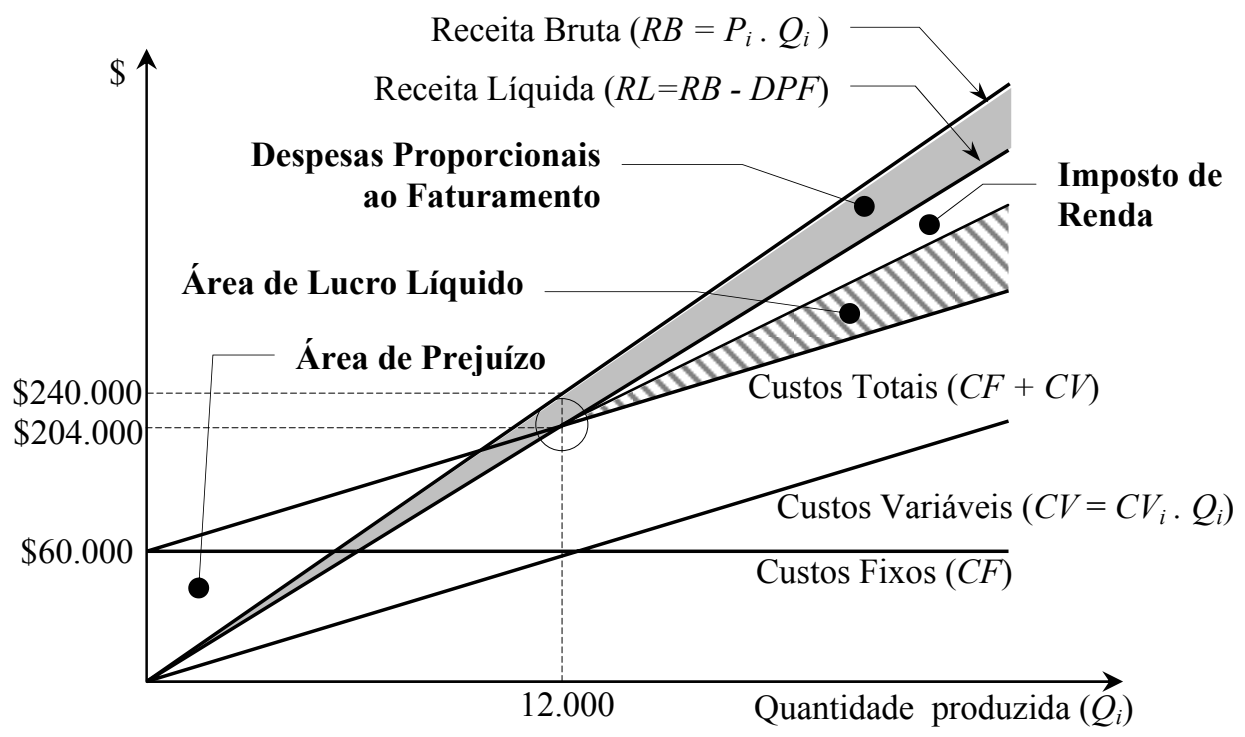

Figura 4.3 - Ponto de Equilíbrio considerando a tributação.

Já o cálculo do lucro líquido, deduzindo-se o imposto de renda, não altera a análise de ponto de equilíbrio, reduzindo apenas a parcela de lucro da empresa a partir de tal ponto. Portanto, não será utilizado neste trabalho as considerações de impactos do imposto de renda sobre o lucro da empresa, pois fugiria do foco da análise proposta inicialmente.

\subsubsection{Análise de Ponto de Equilíbrio Para Dois Produtos ${ }^{4}$}

De acordo com COSTA (1988), quando a empresa produz e vende dois produtos, na existência de custos e despesas fixos e variáveis, ainda, na hipótese linear, o lucro da empresa é obtido pela venda da quantidade $Q_{1}$ do produto 1 da quantidade $Q_{2}$ do produto 2, podendo ser calculado das seguintes equações:

${ }^{4}$ Todas as análises realizadas neste item estão baseadas no trabalho de Magnus Amaral da Costa (1988) - "Relação custo/volume/lucro para multiprodutos". 


$$
L B=P_{1} \cdot Q_{1}+P_{2} \cdot Q_{2}-C V_{1} \cdot Q_{1}-C V_{2} \cdot Q_{2}-C F
$$

O lucro também pode ser calculado através da Margem de Contribuição:

$$
L B=M C_{1} \cdot Q_{1}+M C_{2} \cdot Q_{2}-C F
$$

Como o equilíbrio é obtido quando o lucro é igual a zero $(L B=0)$, a equação acima se transforma em:

$$
C F=M C_{1} \cdot Q_{1}+M C_{2} \cdot Q_{2}
$$

Tendo em vista que a equação acima tem duas incógnitas, $Q_{1}$ e $Q_{2}$, e considerando $C F, M C_{1}$ e $M C_{2}$ positivos, observa-se que não existe um ponto de equilíbrio, dado que a igualdade é sempre válida para qualquer $Q^{\prime}{ }_{1}$ ou $Q^{\prime}{ }_{2}$ especificado.

Geometricamente (figura abaixo), trata-se de uma reta que intercepta o eixo $Q_{1}$ em $C F / M C_{1}$ e o eixo $Q_{2}$ em $C F / M C_{2}$, posto que:

$$
\begin{aligned}
& Q_{1}=\frac{C F}{M C_{1}}-Q_{2} \cdot \frac{M C_{2}}{M C_{1}}, \mathrm{e} \\
& Q_{2}=\frac{C F}{M C_{2}}-Q_{1} \cdot \frac{M C_{1}}{M C_{2}}
\end{aligned}
$$

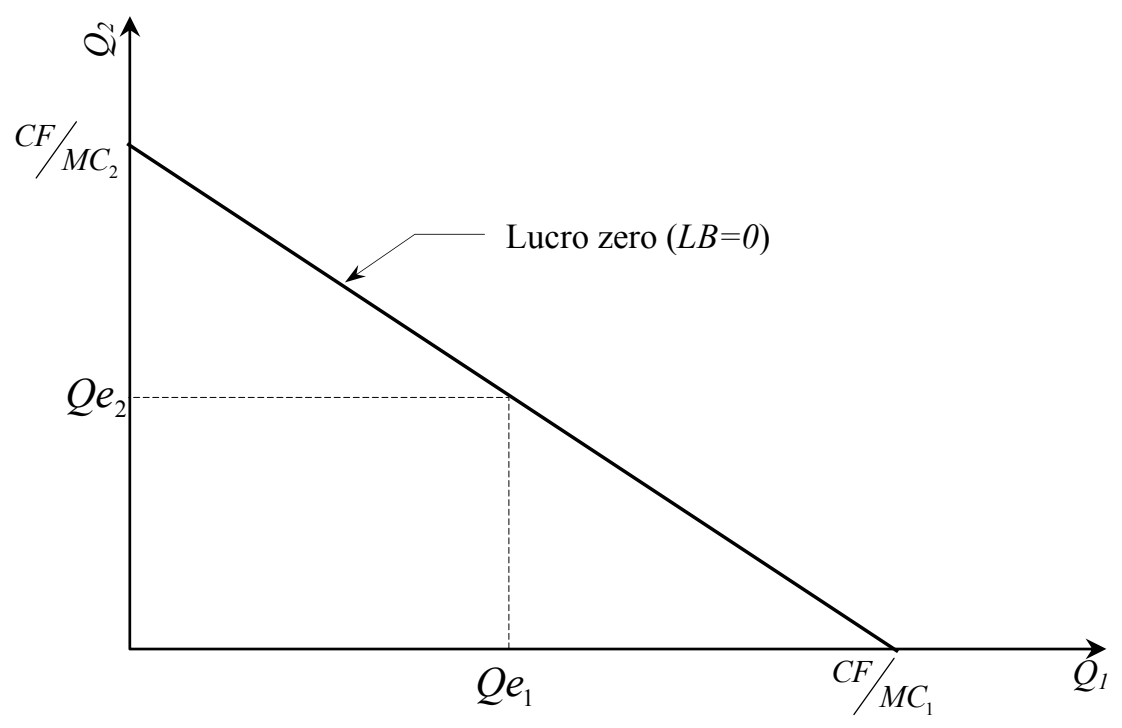

Figura 4.4 - Reta de equilíbrio para dois produtos. 
Qualquer combinação linear da reta definida pela Equação-49 no semi-plano definido por $Q e_{1}$ e $Q e_{2} \geq 0$ é um ponto de equilíbrio e, como qualquer segmento e reta tem infinitos pontos, matematicamente há infinitos pontos de equilíbrio para uma empresa que produz e vende dois produtos, se a unidade de produção de ambos for uma variável contínua, ou finitos pontos, se a unidade de produção de um deles for uma variável discreta.

Portanto, esse conjunto de pontos de equilíbrio denomina-se "conjunto de possibilidades de equilíbrio".

Neste sentido, segundo COSTA (1988), existe um conjunto de possibilidades de equilíbrio nas empresas que produzem e vendem dois ou mais produtos e, por este motivo, o conceito de ponto de equilíbrio só é válido em raríssimos casos, se houver algum. Na prática, pode-se calcular um intervalo de equilíbrio, a partir de um mix possível, considerando-se as possibilidades de mudança, identificando-se dois pontos (ou mais) daquele intervalo, mais importante que um simples ponto (cuja probabilidade de ocorrência é zero).

\subsubsection{Pontos de Equilíbrio por Produto}

Segundo MARTINS (2001), poderíamos a partir do conhecimento dos Custos e Despesas Fixas Identificadas com cada produto, pertencentes a eles sem nenhum rateio, calcular seu ponto de equilíbrio específico. Entretanto, é necessário lembrar que esse Ponto de Equilíbrio é válido para cada um dos produtos para a completa amortização dos seus próprios Custos e Despesas Fixas Identificadas, restando ainda a análise das Despesas Fixas gerais da empresa, não identificadas, comuns a todos os produtos.

Portanto, este Ponto de Equilíbrio pode ser utilizado quando se necessita responder a seguinte pergunta: qual a quantidade de um determinado produto deve ser vendida para pagar seus Custos e Despesas Fixas Próprias? 


\subsection{MARGEM DE SEGURANÇA (MS)}

Segundo BORNIA (1987), a Margem de Segurança é o quanto as vendas da empresa ultrapassam o ponto de equilíbrio. Conseqüentemente, ela representa o quanto as vendas podem cair sem que haja prejuízo para a indústria.

BUNSTEIN (1987), define a Margem de Segurança como sendo a variação possível de perdas que uma certa quantidade considerada de vendas pode apresentar para o produto, ou se for o caso, para a empresa não apresentar prejuízo. Em outros termos, é o volume de vendas que pode ser perdido para que se comprometa todo o lucro por ele propiciado.

COSTA (1988), diz que a Margem de Segurança é a resposta para a seguinte pergunta: "Até quando as quantidades vendidas atualmente poderão cair e a empresa não ter prejuízo? E a receita? E a margem de contribuição?”. A demonstração abaixo foi apresentada pelo autor para uma empresa com apenas dois produtos.

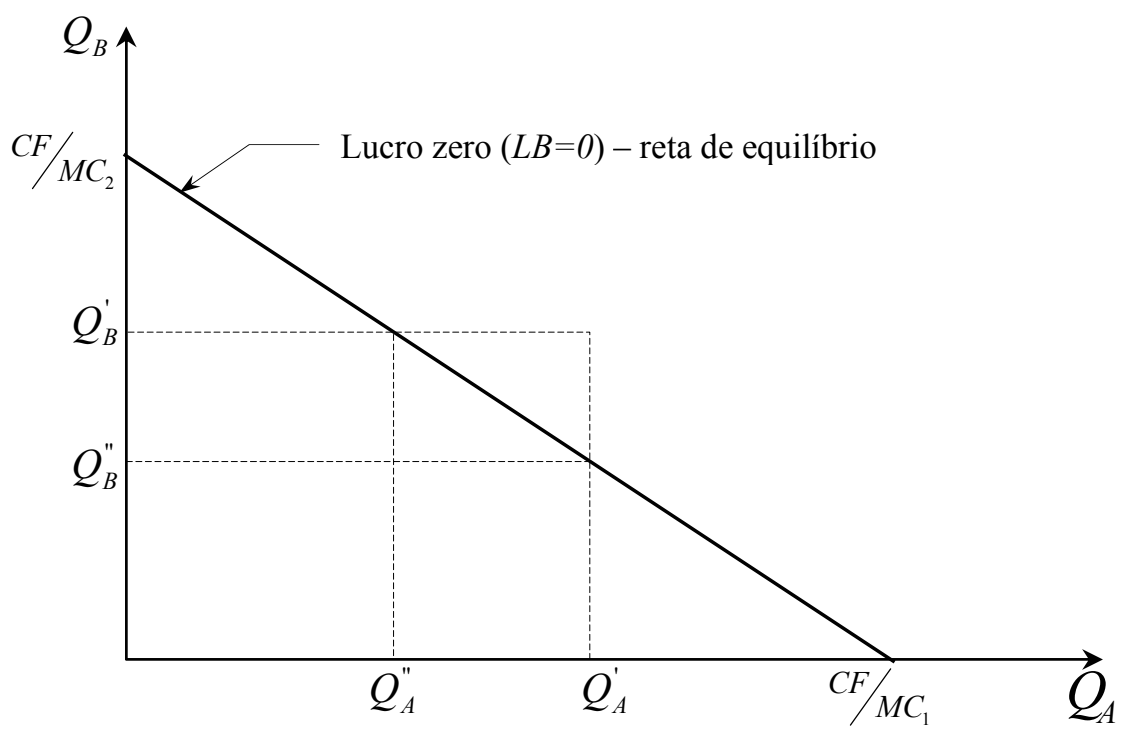

Figura 4.5 - Reta de equilíbrio para dois produtos - Análise de margem de Segurança (COSTA, 1988)

Ainda segundo COSTA (1988), a partir da condição de equilíbrio desenvolvido e apresentado na Figura-4.5 (reta de equilíbrio para dois produtos) reapresentado na 
Figura-4.6; se o nível de atividade for $Q_{A}^{\prime}$ e $Q_{B}^{\prime}$ - condição em que a empresa opera com resultado positivo, mantendo-se $Q_{A}^{\prime}$, verifica-se que $Q_{B}$ pode cair até $Q_{B}^{\prime \prime}$ e, mantendo-se $Q_{B}^{\prime}$, observa-se que $Q_{A}^{\prime}$ pode cair até $Q_{A}^{\prime \prime}$ que a empresa ainda estará em condição equilíbrio, sem apresentar prejuízo. A distância de $\left(Q_{A}^{\prime}, Q_{B}^{\prime}\right)$, nível de atividade atual, à reta de equilíbrio varia para cada ponto definido nesta reta.

Entretanto, pode-se calcular a menor distância de um ponto a uma reta e, desta forma, a menor margem de segurança. Porém observada a Figura abaixo, nota-se que a distância da reta de lucro atual para a reta de equilíbrio é única e, por conseguinte, tem-se uma única margem de segurança para redução de margem de contribuição, independente do mix considerado.

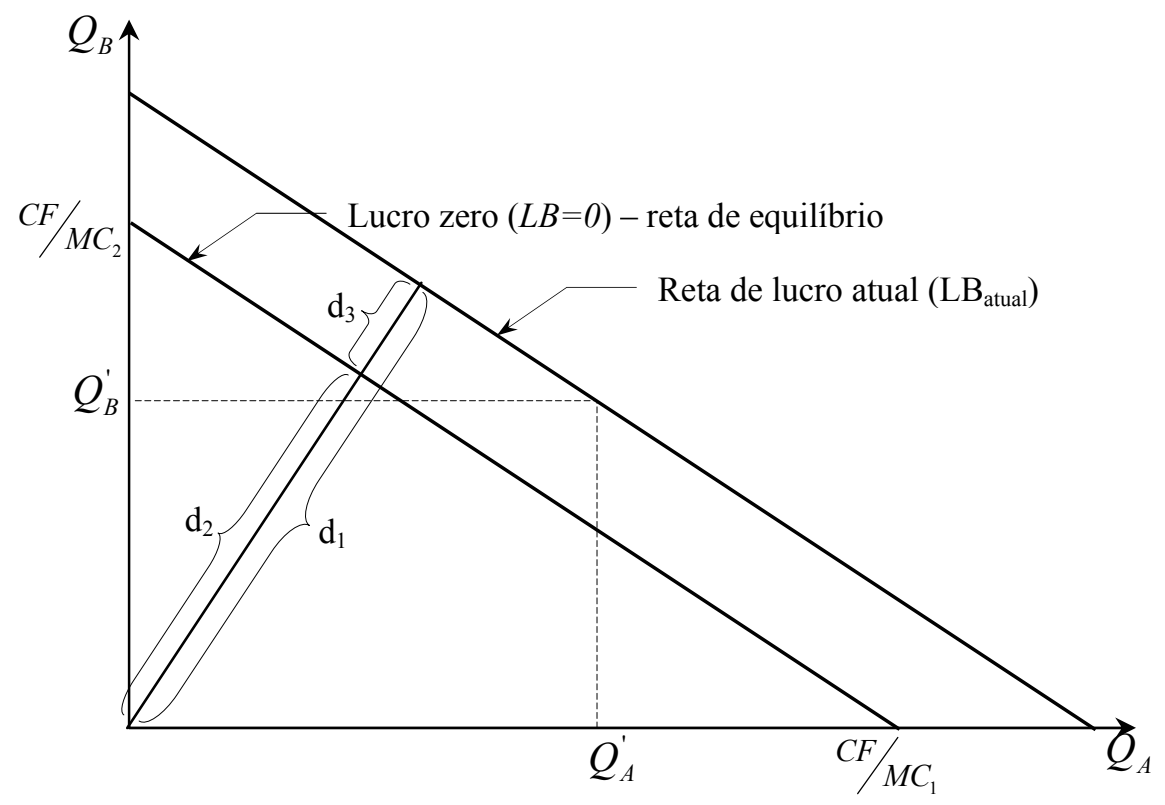

Figura 4.6 - Análise de Margem de Segurança (COSTA, 1988)

Então, para calcular a margem de segurança basta calcular a distância $d_{3}$ do gráfico acima, subtraindo-se as distâncias $d_{2}$ de $d_{1}$. Para o cálculo de $d_{2}$ e $d_{1}$ deve ser utilizado artifício matemático, calculando-se a menor distância da reta à origem. Desta forma, será calculada a menor distância do ponto atual $\left(Q_{A}^{\prime}, Q_{B}^{\prime}\right)$, que gera um certo lucro a reta de equilíbrio, medindo, por conseguinte, o montante de margem de 
contribuição que pode ser diminuído da margem atual antes que a empresa tenha prejuízo. Em números relativos, a margem de segurança seria:

$$
M S=\frac{d_{1}-d_{2}}{d_{1}}=\frac{d_{3}}{d_{1}}
$$

Como $L B_{\text {atual }}=M C_{1} \cdot Q_{1}+M C_{2} \cdot Q_{2}-C F$, a sua distância à origem seria dada pelo teorema:

$$
\begin{aligned}
& d_{1}=\frac{C F+L B_{\text {atual }}}{\sqrt{\left(M C_{1}\right)^{2}+\left(M C_{2}\right)^{2}}} \\
& d_{2}=\frac{C F}{\sqrt{\left(M C_{1}\right)^{2}+\left(M C_{2}\right)^{2}}}
\end{aligned}
$$

Desta forma, teremos:

$$
M S=\frac{L B_{\text {atual }}}{C F+L B_{\text {atual }}}
$$

A equação acima pode ser modificada utilizando-se o conceito de receita atual e receita de equilíbrio; desta forma pode-se demonstrar que se chega ao mesmo resultado posto que a reta que define a receita atual é a mesma que define a margem de contribuição atual, e a reta que define a receita de equilíbrio mantém a mesma combinação do mix atual, isto é:

$$
M S=\frac{\text { Receita Atual }- \text { Receita de Equilibrio }}{\text { Receita Atual }}
$$

A equação acima é totalmente dependente do cálculo do ponto de equilíbrio e, como foi provado no Item-4.1, que o cálculo desse ponto para empresas que operam com multi-produtos é extremamente limitado, fica difícil utilizar tal equação em casos reais.

BUNSTEIN (2005) apresenta uma solução factível para estes casos, de tal sorte, seja independente do cálculo do ponto de equilíbrio, conforme apresentada a seguir a demonstração para o caso de uma empresa com um produto único. Portanto, 
a partir da Equação-56, onde este produto possui apenas um preço de venda e um custo variável, pode-se chegar às seguintes conclusões:

Receita Atual $=Q \cdot P V, \quad$ e

Receita de Equilíbrio $=$ Qe.$P V$, onde:

$Q$ - Quantidade de Venda Atual

Qe - Quantidade de Venda de Equilíbrio

$P V$ - Preço de Venda

Então, substituindo na Equação-56, tem-se:

$$
\begin{aligned}
& M S=\frac{\text { Receita Atual }- \text { Receita de Equilibrio }}{\text { Receita Atual }}=\frac{Q \cdot P V-Q e \cdot P V}{Q \cdot P V} \\
& M S=\frac{Q-Q e}{Q}
\end{aligned}
$$

Multiplicando e dividindo a equação acima pela Margem Bruta de Contribuição unitária do produto, tem-se:

$$
M S=\frac{Q-Q e}{Q} \cdot \frac{M B C u}{M B C u}=\frac{Q \cdot M B C u-Q e \cdot M B C u}{Q \cdot M B C u}
$$

Como pode ser demonstrado pela Equação-31, no ponto de equilíbrio $Q e \cdot M B C u=C D F$, então a equação acima pode ser apresentada da seguinte forma:

$$
M S=\frac{M B C-C D F}{M B C}=\frac{R E S}{M B C}
$$

Portanto, através da Equação-60 a Margem de Segurança pode ser calculada a partir do Resultado da Empresa e da Margem Bruta de Contribuição Total, sem a necessidade de calcular o Ponto de Equilíbrio da empresa.

Pode-se extrapolar a equação acima, deduzida para o caso de produto único, para o caso de empresa com vários produtos comercializados em mercados distintos, objeto desta Tese, podendo ser deduzida através do mesmo modelo. 


\subsubsection{Cálculo do Ponto de Equilíbrio Através da Margem de Segurança}

Como mostrado no título anterior, que a partir do resultado da Equação-60 pode-se calcular a Margem de Segurança sem a necessidade do cálculo prévio do Ponto de Equilíbrio da empresa. Pode-se, então, calcular o Ponto de Equilíbrio da empresa através em função da Margem de Contribuição, o que conceitualmente pode ser explicado através da seguinte definição: "MS é o quanto as vendas da empresa ultrapassam o ponto de equilíbrio". Tal afirmação pode ser apresentada matematicamente, a partir da Equação-58, da seguinte forma:

$$
\begin{aligned}
& \text { Se, } M S=\frac{Q-Q e}{Q}, \text { então: } \\
& M S \cdot Q=Q-Q e \Rightarrow Q e=Q-M S \cdot Q \\
& Q e=Q \cdot(1-M S)
\end{aligned}
$$

A equação acima poderá ser usada para se calcular o ponto de equilíbrio geral da empresa, o ponto de equilíbrio de cada produto e o ponto de equilíbrio de cada produto/mercado, conforme mostrado abaixo:

$$
\begin{aligned}
& Q e_{i}=Q_{i} \cdot(1-M S), \text { onde } Q e=\sum_{i=1}^{n} Q e_{i} \\
& Q e_{i j}=Q_{i j} \cdot(1-M S), \text { onde } Q e_{i}=\sum_{j=1}^{m} Q e_{i}
\end{aligned}
$$

\subsection{GRAU DE ALAVANCAGEM OPERACIONAL (GAO)}

Segundo COSTA (1988), "o grau de alavancagem mede a variação no lucro decorrente de uma variação infinitesimal na quantidade vendida”. Esta definição não é muito clara, pois não há possibilidade de variação infinitesimal na quantidade vendida; quantidade não é medida contínua e sim uma medida discreta podendo variar de unidade em unidade apenas. Então, esta definição pode ser apresentada da 
seguinte forma: "o grau de alavancagem mede a variação no lucro decorrente da variação marginal na quantidade vendida".

Segundo BRUNSTEIN (1987), o GAO indica a "variação em porcentagem dos lucros pela variação de um por cento nas vendas". BRUNSTEIN (2005) diz que o GAO é um número puro, sem dimensão, por representar uma relação entre percentuais, e indica a variação em porcentagem nos resultados provocada por uma variação de um por cento no volume de vendas.

Segundo BRUNSTEIN (1987), a presença de custos fixos proporcionalmente elevados nas atividades de uma empresa, ou de um produto desta empresa, impõe uma condição de análise extremamente relevante quanto à utilização das instalações. De fato, se os custos fixos permanecem estáveis para variações significativas na escala de operações, à medida que as receitas aumentam, os resultados são sensivelmente afetados, alavancando os lucros em função do acréscimo de vendas. Inversamente, uma redução no nível de operações alavanca perdas nos lucros. Estas variações são medidas pelo denominado Grau de alavancagem Operacional.

$$
G A O=\frac{\text { Variação em porcentagem dos lucros }}{\text { Variação em porcentagem das vendas }}
$$

As deduções matemáticas apresentadas a seguir estão baseadas no trabalho de BRUNSTEIN (1987), onde a análise é realizada para o caso onde o preço unitário é considerado constante e o custo direto unitário é fixo, qualquer que seja a ordem de uma unidade de venda ou produção. Esta situação ocorre quando o preço de venda é tabelado ou o mercado é análogo ao da concorrência perfeita, no que se refere ao preço unitário constante. O caso do custo direto unitário fixo, com os custos variáveis linearmente proporcionais à quantidade, é a situação que ocorre como regra geral na prática. Nestas condições, a quantidade em unidades vendidas e o valor monetário das vendas são diretamente proporcionais, o que vai permitir expressar o $G A O$ e a $M S$ indiferentemente um pelo outro.

Suponha uma empresa com um único produto e, a partir da Equação-65, a dedução da equação do $G A O$ será: 


$$
G A O=\frac{\Delta R E S / R E S}{\Delta R B / R B}
$$

Como $\Delta R B / R B=\Delta Q / Q$, e a variação do lucro é medida pela margem de contribuição quando varia-se a quantidade vendida, tem-se:

$$
G A O=\frac{\Delta R E S / R E S}{\Delta Q / Q}
$$

Considerando apenas um produto, pode-se calcular o Resultado da empresa da seguinte forma: $R E S=Q \cdot(P V-C V)-C D F$. Então, substituindo na equação acima, tem-se:

$$
\begin{aligned}
& G A O=\frac{\frac{\Delta Q \cdot(P V-C V)}{Q \cdot(P V-C V)-C D F}}{\Delta R B / R B} \\
& G A O=\frac{\frac{\Delta Q \cdot(P V-C V)}{Q \cdot(P V-C V)-C D F}}{\Delta Q / Q}=\frac{\Delta Q \cdot(P V-C V)}{Q \cdot(P V-C V)-C D F} \cdot \frac{Q}{\Delta Q} \\
& G A O=\frac{Q \cdot(P V-C V)}{Q \cdot(P V-C V)-C D F}=\frac{\text { Margem de Contribuição }}{\text { Lucro }}
\end{aligned}
$$

Segundo BRUNSTEIN (2005), como o Lucro é a diferença entre a MBC e o $\mathrm{CDF}$, esta relação será maior quanto maior for a relação $\mathrm{CDF} / \mathrm{MBC}$, ou seja, o GAO é mais importante quando maior for a relação entre CDF e MBC. Por outro lado, à medida que o nível de operações aumenta, a participação dos CDF na MBC gerada diminui, o que reduz o GAO. Assim, a tendência é a aproximação da $\mathrm{MBC}$ do valor do lucro.

Ainda pode-se continuar o desenvolvimento da seguinte forma: 


$$
G A O=\frac{1}{1-\frac{C D F}{Q \cdot(P V-C V)}}
$$

Observando-se que $C D F /(P V-C V)$ é a expressão do ponto de equilíbrio em unidades $(Q e)$, finalmente tem-se:

$$
G A O=\frac{1}{1-\frac{Q e}{Q}}
$$

Então, finalmente, GAO pode ser calculada da seguinte forma:

$$
G A O=\frac{1}{\frac{Q-Q e}{Q}}=\frac{Q}{Q-Q e}=\frac{1}{M S}=\frac{M B C}{R E S}
$$

Comparando as Equações-73 e 60, pode-se mostrar que $G A O$ e $M S$ são inversamente proporcionais, e com valores tais que seu produto é sempre a unidade.

\subsubsection{Margem de Segurança x Grau de Alavancagem Operacional}

Podemos observar através da Figura-4.7, o relacionamento entre a MS e o GAO. A Equação-72 do GAO pode ser representada graficamente por uma hipérbole deslocada de seu eixo original gerada pela equação $y=1 / x$, o mesmo acontecendo com a Margem de Segurança.

Para análise gráfica, suponha duas empresas $X$ e $Y$, que produzem periodicamente $Q x$ e $Q y$, respectivamente, conforme mostrado graficamente abaixo: 


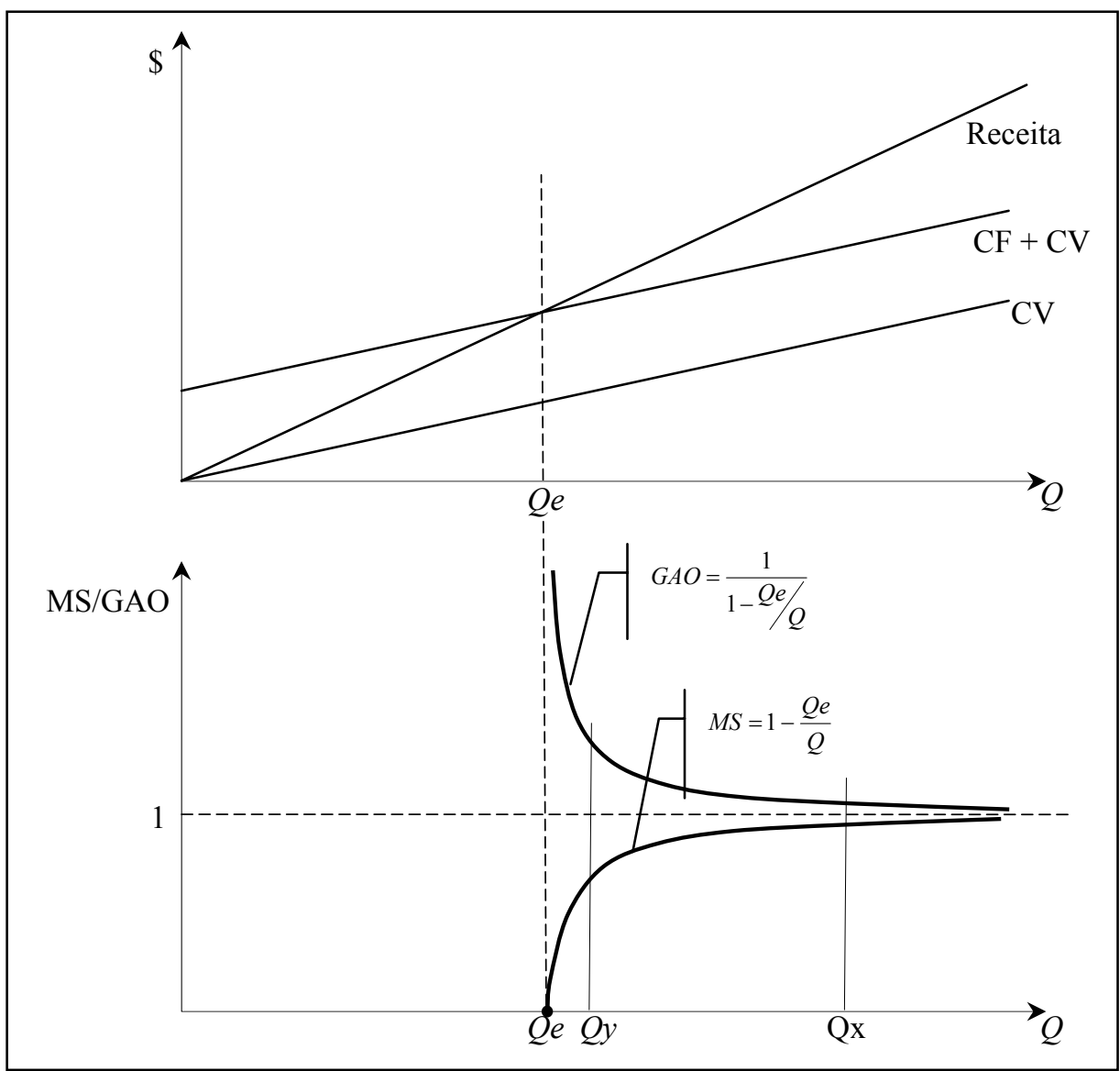

Figura 4.7 - Variação do $G A O$ e da $M S$. (BRUNSTEIN 2005, PP.149)

À medida que $Q$ se afasta de $Q e$ o valor da $M S$ cresce, enquanto o GAO decresce. Para valores altos da MS, o GAO é relativamente pequeno. Esta verificação é importante nas interpretações com relação a um nível de operações real ou desejado.

Analisando a Figura-4.7, pode-se concluir que a empresa $X$, com uma produção $Q x$, comparada à empresa $Y$, possui uma MS alta e o GAO baixo, sendo então uma empresa mais estável que a $Y$, pois ela pode perder um volume de vendas maior até chegar em seu ponto de equilíbrio e, em conseqüência disso, uma variação no volume de vendas causa menor impacto no resultado da empresa $X$ comparado ao resultado obtido através da mesma variação da empresa $Y$. 
Portanto, quanto maior o GAO, maior será o risco da empresa e, quanto maior o MS, menor será o risco da empresa, pois esses indicadores possuem equações inversas, conforme as demonstrações realizadas neste Capítulo $(G A O=1 / M S)$.

Segundo BRUNSTEIN (2005), o GAO e a MS têm várias aplicações na análise econômica das atividades de uma empresa. Podemos citar decisões de promoção e de negociações para incremento de vendas. Nestes casos, os acréscimos de despesas ou redução das receitas poderão ser confrontados com os ganhos a serem obtidos nos resultados. Quando tem vários produtos ou atividades disputando um mesmo recurso que pode ser aplicado para expansão do nível de operações, o Grau de Alavancagem Operacional é um bom indicador de onde aplicar.

Outra utilização interessante destes conceitos é no estudo da criação de uma nova unidade industrial para a produção de um novo produto para a empresa. Neste tipo de situação o GAO e a MS fornecem importantes subsídios para a análise econômica e a tomada de decisão final.

\subsection{ANÁLISE DE SENSIBILIDADE PARA ALTERAÇÕES NO CUSTO- VOLUME-LUCRO}

O gráfico do ponto de equilíbrio, e em especial o gráfico lucro/volume, pode ser usado para mostrar as mudanças nas características de operações da firma. Por exemplo, se a administração estuda uma mudança na política que altere a relação entre custos fixos e variáveis, o impacto dessas alterações pode ser visualizado no gráfico através de mudanças na declividade da reta ou no ponto de equilíbrio.

Para exemplificar tal operação, suponha uma empresa que produza apenas um produto que, inicialmente, esteja operando com uma demanda de 80 unidades por período, Custos e Despesas Fixas no valor de \$60,00; Preço de Venda igual a $\$ 4,00$ e Custos Variáveis no valor de $\$ 2,80$. Então a situação atual desta empresa pode ser assim representada:

$$
\begin{aligned}
& M B C_{u}=4-2,8=1,20 \Rightarrow M B C=1,20 \cdot 80=96,00 \\
& \Rightarrow R E S=96-60=36,00
\end{aligned}
$$




$$
\begin{aligned}
& Q e=\frac{60}{1,20}=50 \text { unidades. } \\
& \begin{array}{c}
M S=\frac{R E S}{M B C}=\frac{36}{96}=0,375=37,5 \% ; \text { a empresa poderá perder até } 37,5 \% \\
\text { de suas vendas antes que haja prejuízo. } \\
G A O=\frac{M B C}{R E S}=\frac{96}{36}=2,67 ; 1 \% \text { de variação nas vendas causa } 2,67 \% \text { de } \\
\quad \text { variação no resultado da empresa. }
\end{array}
\end{aligned}
$$

As simulações a seguir, tornam-se necessárias para o entendimento do comportamento de uma empresa.

$1^{a}$ Simulação: redução dos custos variáveis em $\mathrm{R} \$ 0,80$ por unidade.

Na Figura-4.8a, a declividade da curva de margem de contribuição aumenta em função da redução dos custos variáveis de $\$ 0,80$ por unidade, o que faz crescer a margem de contribuição de $\$ 1,20$ para $\$ 2,00$ por unidade. O ponto de equilíbrio passa de 50 para 30 unidades; a margem de segurança passa de $37,5 \%$ para $62,5 \%$; o grau de alavancagem passa de 2,67 para 1,60. Então, a redução nos custos variáveis acarreta redução de risco da empresa, reduzindo o ponto de equilíbrio, o grau de alavancagem e aumentando a margem de segurança, sendo que o aumento nos custos variáveis promove um efeito contrário.

$2^{a}$ Simulação: redução dos custos fixos em R \$ 20,00.

Na Figura-4.8b, o ponto de interceptação com o eixo do lucro subiu um degrau, em função da redução dos custos fixos de $\$ 60,00$ para $\$ 40,00$; com os custos variáveis permanecendo inalterados. O ponto e equilíbrio passou de 50 para 33 unidades; a margem de segurança passa de 37,5\% para 58,3\%; o grau de alavancagem passa de 2,67 para 1,71. Então, a alteração nos custos e despesas fixas promovem um efeito igual ao efeito da variação nos custos variáveis. 
$3^{\text {a }}$ Simulação: redução dos custos variáveis em $\mathrm{R} \$ 0,80$ por unidade e aumento nos custos fixos em R $\$ 20,00$.

Na Figura-4.8c, mostra uma redução nos custos variáveis que fazem aumentar a margem de contribuição para $\$ 2,00$ e um aumento de $\$ 20,00$ nos custos fixos. A declividade aumenta, mas em compensação o ponto de interceptação no eixo de lucro cai. Como resultado o ponto de equilíbrio passa de $\$ 50$ para 40 unidades; a margem de segurança passa de $37,5 \%$ para $50 \%$; o grau de alavancagem passa de 2,67 para 2,00. Com estas alterações, pode-se perceber, que a situação da empresa melhora, pois o impacto da redução dos custos variáveis é maior do que o aumento nos custos fixos para uma produção de 80 unidades.

Mudanças na política que reflitam um impacto nos preços de venda ou na quantidade de produtos vendidos têm um reflexo similar ao abordado. Por exemplo, aumentos ou reduções no preço de venda podem alterar a declividade da reta da margem de contribuição. Aumentos na quantidade vendida podem aumentar o lucro esperado, etc.

Por outro lado, quando os custos e despesas fixas de uma empresa são acrescidos (ou decrescidos) de um valor especifico em percentual (por exemplo $20 \%$ ), o ponto de equilíbrio da empresa também será acrescido (ou decrescido) deste valor

Por exemplo, se os Custos e Despesas Fixas da empresa acima $(\mathrm{R} \$ 60,00)$ sofrerem um aumento de $20 \%$ ( $\$$ \$72,00), o novo ponto de equilíbrio sofrerá o mesmo aumento de $20 \%$, como mostrado a seguir:

$$
Q e=\frac{60 \cdot(1+0,20)}{1,20}=50 \cdot 1,20=60 \text { unidades }
$$




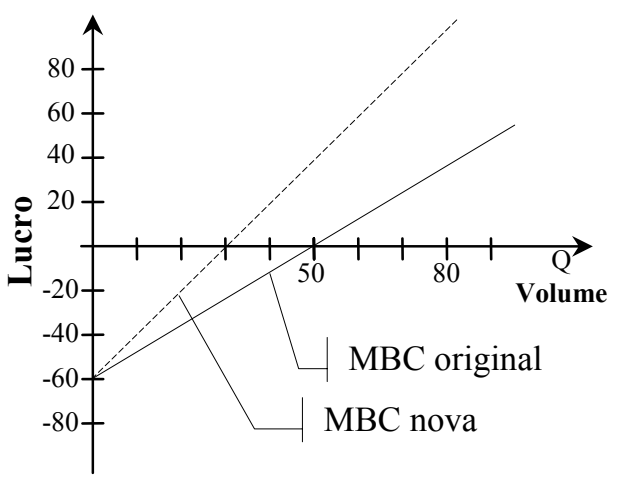

Figura 4.8a

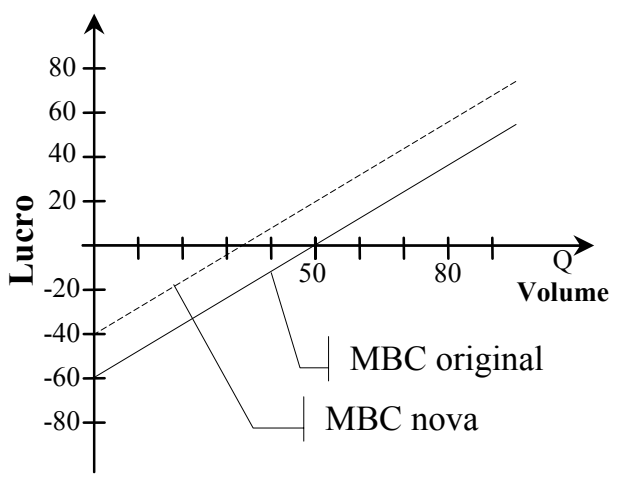

Figura $4.8 b$

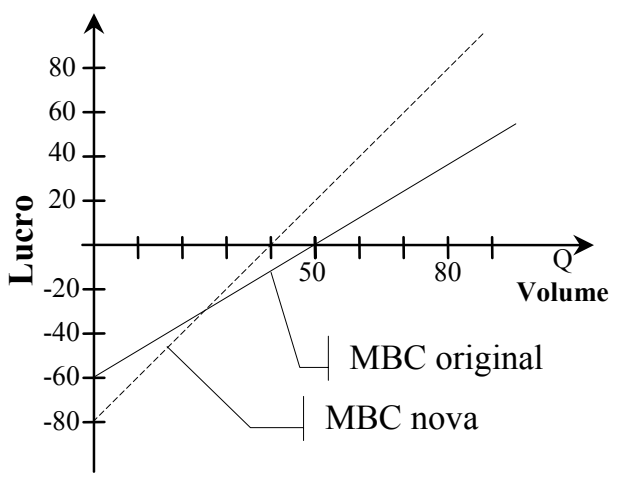

Figura 4.8c

Figura 4.8 - Efeitos de alterações de políticas diversas na relação lucro-volume. (CORRAR, 1990, pp22) 


\section{MODELAGEM ECONÔMICA DE UM SISTEMA COM UMA UNIDADE CENTRAL ADMINISTRATIVA E VÁRIAS UNIDADES DE NEGÓCIOS}

Neste capítulo é realizada a modelagem dos indicadores de posição econômica para o problema proposto, unindo todos os conceitos descritos nos capítulos anteriores. A apresentação de uma aplicação teórica faz-se necessário para que o leitor possa entender a aplicação, a metodologia de identificação, a coleta dos dados (variáveis independentes) e o cálculo e a análise das variáveis dependentes obtidas.

Portanto, para que a modelagem aqui apresentada possa ser aplicada, é preciso que a empresa se enquadre no perfil pré-estabelecido no Capítulo-2, isto é, as Variáveis de Independentes (definidas no item "1.2.4. Variáveis de Pesquisa") possam ser tratadas conforme apresentadas na Figura-5.1. Esta figura mostra também os pontos de alocação dos custos, das despesas e da obtenção de receita, facilitando a coleta das informações nas aplicações em casos reais, que serão apresentados no próximo capítulo.

Se a estrutura administrativa da empresa, objeto do estudo e/ou aplicação do modelo não se enquadrar nas condições pré-estabelecidas no Capítulo-2 e, não puder ser enquadrada na Figura-5.1, a modelagem pode não ser adequada ou não se enquadrar nas especificidades da empresa e, ainda, a modelagem pode necessitar de alterações para sua correta aplicação; devendo neste último caso ser objeto de outro estudo. Empresas com apenas uma unidade, não possuindo sede administrativa e que tenham o perfil de uma UEN, podem utilizar parte da modelagem descrita. 


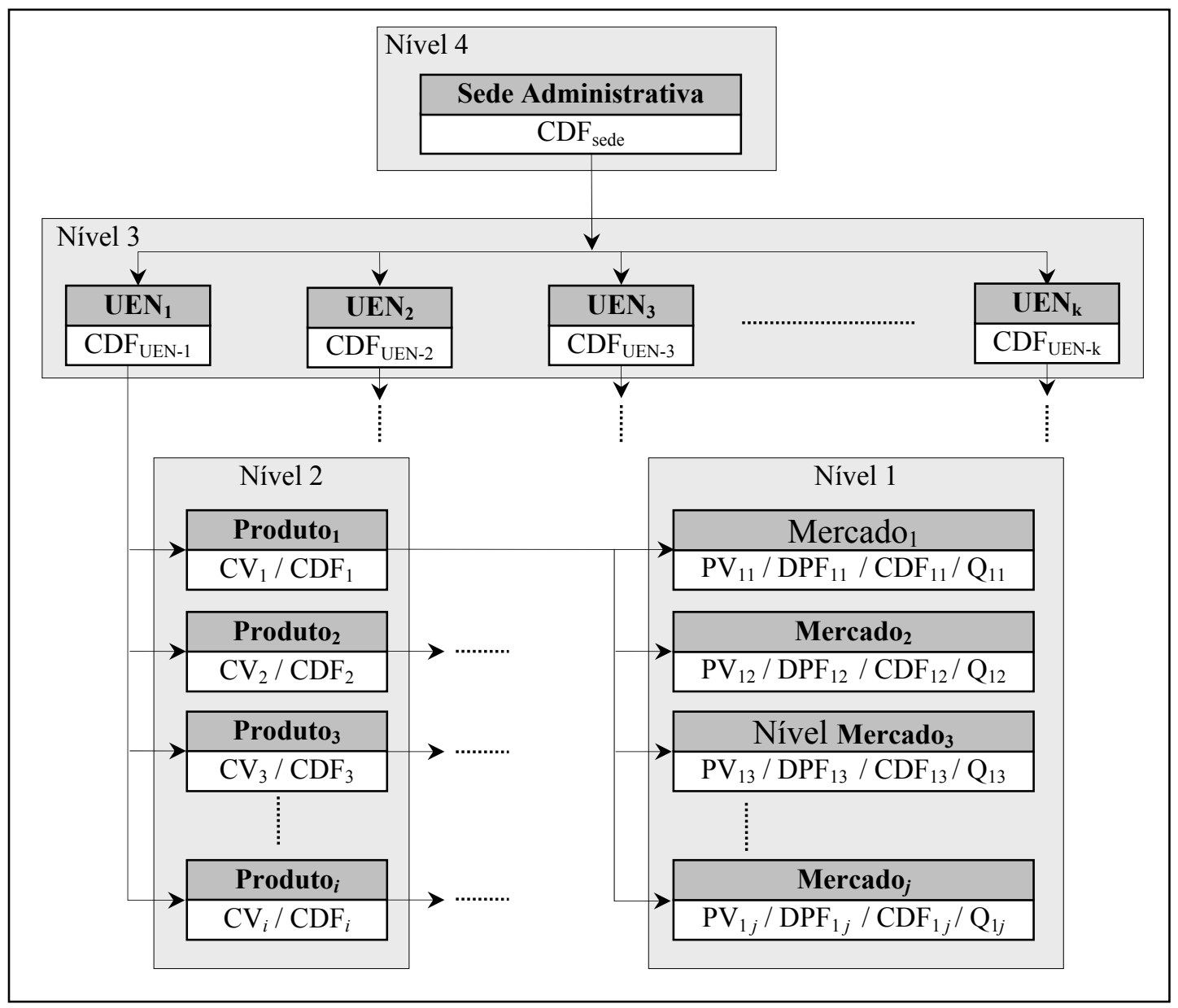

Figura 5.1 - Modelo de uma Estrutura Organizacional com Sede Administrativa e Várias Unidades de Negócios

\subsection{IDENTIFICAÇÃO DAS VARIÁVEIS INDEPENDENTES}

É necessário realizar a identificação dos custos e despesas fixas da sede, de cada UEN e específica de cada produto e/ou produto/mercado, quando houver. Como segunda etapa, é preciso identificar os custos variáveis de cada produto; os custos proporcionais ao faturamento (impostos, comissões, transportes etc.) e os custos proporcionais à quantidade vendida (matéria-prima, embalagens e insumos). 
Então, de maneira mais clara, a empresa pode ser vista sob a ótica de quatro níveis distintos, como mostrado na Figura-5.1.

No Nível-1, representado pelos $j$ mercados onde cada produto pode ser comercializado. Neste nível os produtos também podem ter custos e despesas fixas próprias, no caso de um show room ou uma equipe de vendas disponível para um determinado produto; os preços de venda dos produtos também podem variar de um mercado para outro, devido às distâncias entre o mercado consumidor e a UEN e/ou devido à variação das Despesas Proporcionais ao Faturamento, que são dependentes das políticas de impostos, do valor do transporte, das comissões a serem pagas etc. $\mathrm{O}$ volume de vendas também deve ser identificado nesta fase do trabalho.

As Unidades Estratégicas de Negócios e a Sede Administrativa, respectivamente Níveis 3 e 4, possuem custos e despesas fixas próprias identificadas para poder administrar todo o conjunto. O Nível-2, representado pelos produtos de cada UEN, pode ter custos e despesas fixas próprias, no caso da empresa disponibilizar uma máquina ou equipamento na fabricação de um determinado produto, e custos variáveis que são independentes do mercado onde serão vendidos e dependem de como são fabricados e das matérias-primas e insumos necessários a sua fabricação.

Se a empresa em análise for do setor de serviço ou comércio, o modelo de análise e coleta de dados é a mesma, podendo ter variações de nomeclatura, principalmente na identificação dos Custos Variáveis, que são identificados no Nível-2.

\subsubsection{Orçamento: Alocação de Recursos}

Segundo HORNGREN, SUNDEM e STRATTON (2004), a maioria das pessoas associa a palavra "orçamento" com limitações de gastos. A maioria das organizações empresariais usa orçamentos para focalizar a atenção nas operações e finanças da empresa, não apenas no limite de gastos. Os orçamentos destacam 
antecipadamente os problemas potenciais e as vantagens, permitindo aos gestores tomar atitudes para evitar esses problemas ou usar sabiamente as vantagens.

O orçamento é uma ferramenta que apóia os gestores em suas funções de planejamento e controle, não apenas para examinar o futuro, mas também para examinar o passado, podendo ser utilizados como um nível de referência que permite aos gestores comparar o desempenho real com o desempenho estimado ou desejado.

Três benefícios principais do orçamento são os seguintes:

- Os orçamentos compelem os gestores a pensar no futuro pela formalização de suas responsabilidades de planejar.

- Os orçamentos fornecem expectativas definidas, que são a melhor estrutura para julgar o desempenho subseqüente.

- Os orçamentos ajudam os gestores na coordenação de seus esforços, de modo que os planos das subunidades da organização satisfaçam os objetivos da organização como um todo.

"O orçamento é a ferramenta contábil comum que as empresas usam para planejar e controlar o que elas precisam fazer para satisfazer seus clientes e ter sucesso no mercado. Orçamentos proporcionam uma medida dos resultados financeiros que uma empresa espera ter de suas atividades planejadas. Ao planejarem para o futuro, os gerentes aprendem a antecipar problemas em potencial e como evitá-los. Em vez de enfrentarem problemas futuros, os gerentes podem direcionar suas energias na exploração de oportunidades" (HORNGREN; DATAR; FOSTER, 2004, p.165).

Orçamento é uma parcela significativa da maioria dos sistemas de controle da administração, podendo oferecer as seguintes vantagens:

- Impulsionar o planejamento e a implementação estratégica de planos.

- Proporcionar uma estrutura para a avaliação do desempenho.

- Motivar administradores e funcionários.

- Promover a coordenação e a comunicação entre subunidades dentro da empresa. 
Segundo ATIKINSON (2000), o orçamento nas empresas reflete as condições quantitativas de como alocar recursos financeiros para cada subunidade organizacional, com base em suas atividades e nos objetivos de curso prazo. Por exemplo, o gerente da filial de um banco pode querer aumentar a participação no mercado local. Isto pode requerer um orçamento de gastos maiores do que do ano anterior a fim de aumentar a quantia de publicidade local; implementar um programa de treinamento para o pessoal, aumentar seus esforços para melhorar o atendimento ao consumidor e reformar o edifício, atrair mais clientes. Assim, um orçamento é uma expressão quantitativa das entradas de dinheiro para determinar se um plano financeiro atingirá os objetivos organizacionais. Orçamentação é o processo de preparação de orçamentos. Algumas funções dos orçamentos:

- Os orçamentos também prevêem meios para comunicar as metas da empresa a seus membros. Orçar as atividades das unidades organizacionais pode refletir quão bem os gerentes das unidades entendem as metas da empresa e propiciam oportunidade para seus planejadores seniores corrigirem distorções nas metas da empresa.

- O orçamento também serve para coordenar muitas atividades de uma empresa.

- O orçamento pode prover indicação de problemas potenciais e pode servir como ferramenta para ajudar a encontrar soluções.

- Os orçamentos são preparados para períodos específicos, o que permite aos gerentes comparar os resultados efetivos para o período com os resultados planejados.

Ainda, segundo ATIKINSON (2000), geralmente o orçamento requer três tipos de recursos para períodos diferentes:

- Recursos flexíveis, que resultam em custos variáveis. Estes podem ser obtidos ou podem ser descartados no curto prazo.

- Recursos comprometidos a médio prazo, que resultam em custos fixos.

- Recursos comprometidos a longo prazo, que resultam em custos fixos.

O Orçamento Mestre é dividido em dois tipos principais de orçamentos: 
- Orçamentos operacionais, abrangendo atividades como vendas, compras e produção.

- Orçamentos financeiros, tais como balanço patrimonial, demonstração de resultado e demonstração de fluxo de caixa, identificam as conseqüências financeiras esperadas das atividades resumidas nos orçamentos operacionais.

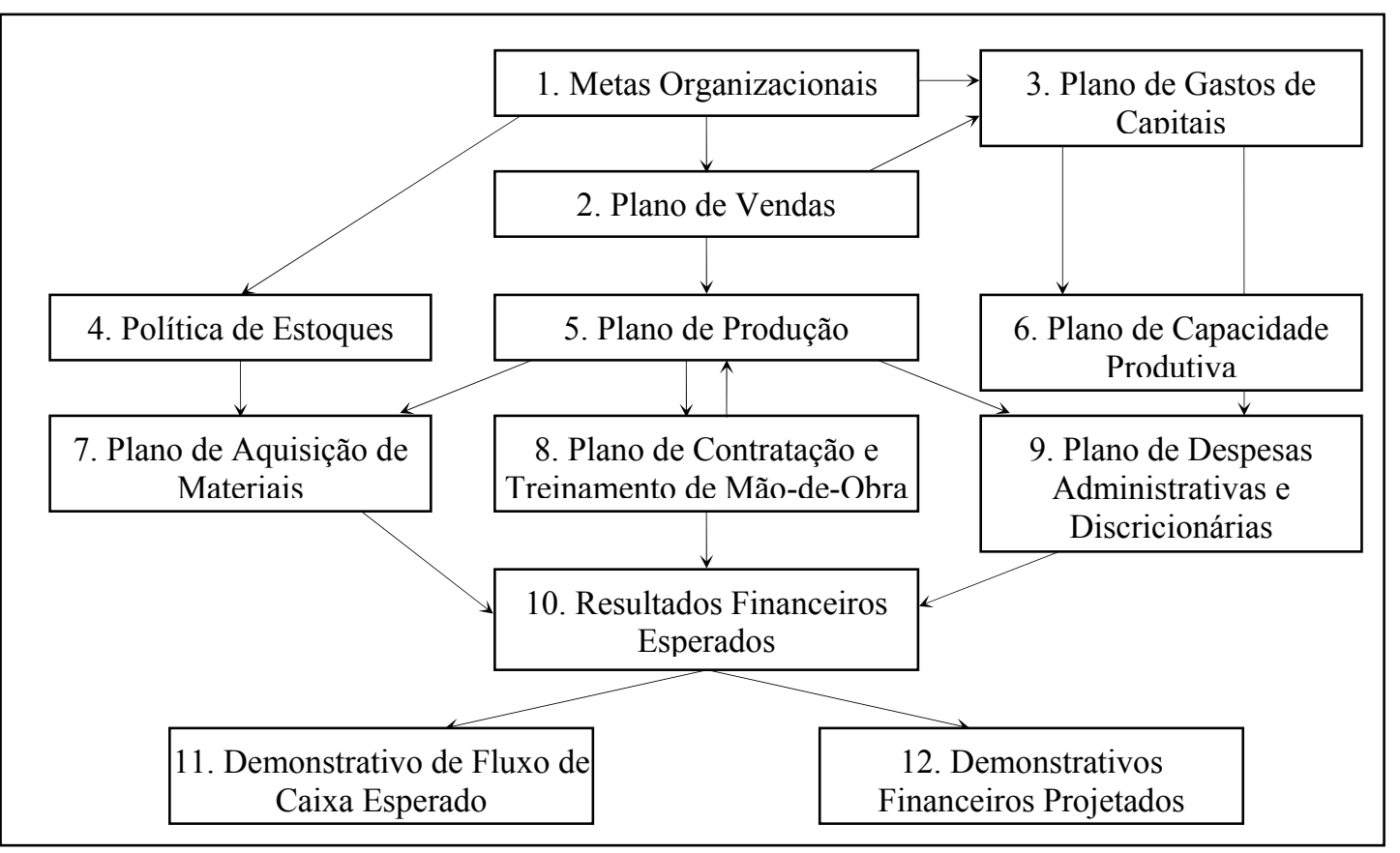

Figura 5.2 - Orçamento Mestre. (ATKINSON, 2000, p. 469)

\section{ORCAMENTOS OPERACIONAIS}

Orçamentos operacionais consistem, tipicamente, em seis planos operacionais:

- Plano de Vendas - identifica o nível planejado de vendas para cada produto.

- Plano de Gastos de Capital - especifica os investimentos de capital a longo prazo, tais como prédios e equipamentos, que devem ser realizados para atender aos objetivos da atividade.

- Plano de Produção - programa todas as necessidades de produção.

- Plano de Aquisição de Materiais - programa todas as atividades de compras necessárias. 
- Plano de Contratação e de Treinamento de Mão-de-Obra - especifica o número de pessoas que a empresa deve contratar e treinar ou despedir para alcançar os objetivos de suas atividades.

- Plano de Gastos Administrativo e Discicionário - inclui administração, assessoria, pesquisa e desenvolvimento e publicidade.

Os orçamentos operacionais especificam as exigências esperadas e os resultados de qualquer atividade de venda, de gasto de capital, de produção, de compras e administrativas durante o período de planejamento. O pessoal operacional usa esses planos para guiar e coordenar o nível de várias atividades durante o período de planejamento.

\section{ORCAMENTOS FINANCEIROS}

Os planejadores preparam, para avaliar as conseqüências financeiras de decisões propostas, o balanço patrimonial e a demonstração de fluxos de caixa projetados de dois modos:

- Planejar quando será gerado excesso de caixa, de forma que eles possam empreender investimentos a curto prazo.

- Organizar para atender a qualquer escassez de caixa.

\subsubsection{Orçamento $x$ Identificação das Variáveis Independentes}

Para facilitar a identificação das variáveis independentes e implantar o modelo discutido em uma empresa, é necessário que as informações sejam identificadas corretamente, conforme discutido no item 5.1.

Para tanto, o sistema orçamentário e o sistema contábil da empresa devem se adequar às necessidades de descrição, apuração, alocação e apresentação dos dados descritos neste trabalho, respeitando as características e especificidades dos custos e despesas fixas da empresa e identificado-os conforme descrito, respeitando os Níveis 1, 2, 3 e 4 apresentados na Figura-5.1. 


\subsection{CÁlCULO DOS INDICADORES DE POSIÇÃO ECONÔMICA A PARTIR DA MODELAGEM PROPOSTA}

No capítulo anterior foram apresentados indicadores de posição econômica de forma genérica, algumas vezes para empresas com fabricação e comercialização de apenas um produto em um mercado. A partir dos conceitos desenvolvidos, pode-se chegar ao cálculo dos indicadores de posição econômica para empresas objeto desse estudo, com vários produtos podendo ser comercializados em diversos mercados diferentes, dispersos ou não geograficamente, como mostrado abaixo.

\subsubsection{Grau de Alavancagem Operacional - GAO}

\section{GAO Para Empresas com Dois Produtos}

No Capítulo anterior foi desenvolvida a equação do GAO considerando apenas um produto. A demonstração abaixo apresenta o equacionamento do GAO para uma empresa que opera com dois produtos, sem distinção de mercado em que comercializa seus produtos.

Portanto, a partir da Equação-67 e, considerando que:

$$
\begin{aligned}
& \Delta Q_{1} / Q_{1}=\Delta Q_{2} / Q_{2}=\Delta Q_{T} / Q_{T}, \text { tem-se: } \\
& G A O=\frac{\Delta R E S / R E S}{\Delta Q / Q}=\frac{\frac{\Delta R E S_{1}+\Delta R E S_{2}}{R E S}}{\frac{\Delta Q_{T}}{Q_{T}}}=\frac{\frac{\Delta R E S_{1}}{R E S}}{\frac{\Delta Q_{T}}{Q_{T}}}+\frac{\frac{\Delta R E S_{2}}{R E S}}{\frac{\Delta Q_{T}}{Q_{T}}} \\
& G A O=\frac{\frac{\Delta R E S_{1}}{R E S}}{\frac{\Delta Q_{1}}{Q_{1}}}+\frac{\frac{\Delta R E S_{2}}{R E S}}{\frac{\Delta Q_{2}}{Q_{2}}}=\frac{\Delta R E S_{1}}{R E S} \cdot \frac{Q_{1}}{\Delta Q_{1}}+\frac{\Delta R E S_{2}}{R E S} \cdot \frac{Q_{2}}{\Delta Q_{2}}
\end{aligned}
$$


Multiplicando e dividindo a equação acima pela Margem Bruta de Contribuição Unitária, tem-se:

$$
\begin{aligned}
& G A O=\frac{\Delta R E S_{1}}{R E S} \cdot \frac{Q_{1}}{\Delta Q_{1}} \cdot \frac{M B C u_{1}}{M B C u_{1}}+\frac{\Delta R E S_{2}}{R E S} \cdot \frac{Q_{2}}{\Delta Q_{2}} \cdot \frac{M B C u_{2}}{M B C u_{2}} \\
& G A O=\frac{\Delta R E S_{1}}{\Delta Q_{1} \cdot M B C u_{1}} \cdot \frac{M B C_{1}}{R E S}+\frac{\Delta R E S_{2}}{\Delta Q_{2} \cdot M B C u_{2}} \cdot \frac{M B C_{2}}{R E S} \\
& \text { Como por definição, } \triangle R E S=\Delta Q \cdot M B C u \Rightarrow \frac{\Delta R E S_{1}}{\Delta Q_{1} \cdot M B C u_{1}}=1, \text { então: } \\
& G A O=\frac{M B C_{1}}{R E S}+\frac{M B C_{2}}{R E S}
\end{aligned}
$$

Conclui-se que para o cálculo do GAO geral de uma empresa com dois produtos é preciso somar o GAO dos dois produtos individuais. O GAO de um produto pode ser interpretado como a variação nos lucros da empresa a partir da variação de $1 \%$ das vendas desse produto. O GAO geral da empresa pode ser interpretado como a variação nos lucros da empresa a partir da variação de $1 \%$ das vendas dos dois produtos simultaneamente.

\section{GAO Para Empresas com Sede Administrativa e Várias UENs}

A partir da Equação-73 (Capítulo 4) apresentada abaixo, que foi desenvolvida para uma empresa (ou UEN) com um único produto, e da dedução realizada acima pode-se desenvolver equações para empresas que produzam e comercializam $m$ produtos em $n$ mercados, conforme apresentado abaixo:

$$
G A O=\frac{M B C}{R E S}
$$

Desta forma, pode-se chegar à equação do GAO do Produto $i$ no mercado $\boldsymbol{j}$ em relação a $\mathbf{U E N}_{\boldsymbol{k}}$, representado por $G A O_{\left(P_{i j} / U E N_{k}\right)}$, conforme mostrado na Equação-81 adiante. O resultado dessa operação pode ser interpretado como a variação em porcentagem dos lucros da UEN, a partir da variação de $1 \%$ nas vendas 
de um determinado produto em um determinado mercado onde este produto é comercializado.

$$
G A O_{\left(P_{i j} / U E N_{k}\right)}=\frac{M B C_{i j}}{R E S_{U E N-k}}
$$

Partindo-se da dedução acima, pode-se calcular o Grau de Alavancagem Operacional do produto-i em relação a $\boldsymbol{U E N}_{\boldsymbol{k}}$, representado por $G A O_{\left(P_{i} / U E N_{k}\right)}$ (Equação-82). O resultado desta operação pode ser interpretado como a variação em porcentagem dos lucros da UEN, a partir da variação de $1 \%$ nas vendas de um determinado produto em todos os mercados onde este produto é comercializado.

Como o GAO de um produto é a somatória dos GAOs deste produto em todos os mercados onde é vendido, tem-se:

$$
G A O_{\left(P_{i} / U E N_{k}\right)}=\sum_{j=1}^{n} G A O_{\left(P_{i j} / U E N_{k}\right)}
$$

A equação acima, também pode ser escrita da seguinte forma:

$$
G A O_{\left(P_{i} / U E N_{k}\right)}=\frac{\sum_{j=1}^{n} M B C_{i j}}{R E S_{U E N-k}}, \text { GAO do produto } i \text { na UEN } k
$$

Tem-se que tomar cuidado para não confundir conceitos e utilizar equações que levam a resultado errôneos, pois em casos em que o(s) produto(s) não possuem Custos e Despesas Fixas Próprias nos mercados onde são vendidos a equação abaixo também é valida, em caso contrário não:

$$
G A O_{\left(P_{i} / U E N_{k}\right)}=\frac{\sum_{j=1}^{n} M B C_{i j}}{R E S_{U E N-k}}=\frac{M B C_{i}}{R E S_{U E N-k}}, \text { como dito, esta equação somente }
$$

poderá ser utilizada quando o produto não possuir CDF em todos os mercados onde é vendido, pois, neste caso, têm-se:

$$
M B C_{i}=\sum_{j=1}^{n}\left(M B C_{i j}-C \not D F_{i j}\right)=\sum_{j=1}^{n} M B C_{i j} \text {, que torna a equação acima valida. }
$$


Neste mesmo sentido, o cálculo do GAO de uma UEN específica, apresentado abaixo pela Equação-84, representa a variação em porcentagem dos lucros desta UEN, a partir da variação de $1 \%$ nas vendas de todos os produtos em todos os mercados onde estes produtos são comercializados.

$$
\begin{gathered}
G A O_{U E N_{k}}=\frac{\sum_{j=1}^{n} \sum_{i=1}^{m} M B C_{i j}}{R E S_{U E N-k}} \\
G A O_{U E N_{k}}=\frac{M B C_{11}}{R E S_{U E N-k}}+\frac{M B C_{12}}{R E S_{U E N-k}}+\ldots+\frac{M B C_{1 n}}{R E S_{U E N-k}}+\frac{M B C_{21}}{R E S_{U E N-k}}+\ldots+\frac{M B C_{2 n}}{R E S_{U E N-k}}+ \\
+\frac{M B C_{m 1}}{R E S_{U E N-k}}+\ldots+\frac{M B C_{m n}}{R E S_{U E N-k}}
\end{gathered}
$$

Portanto, para o cálculo do vários GAOs apresentados acima, é preciso identificar a Margem de Contribuição de cada produto em cada mercado onde eles são comercializados, sendo de suma importância a identificação de Custos e Despesas Próprias dos produtos, aumentando desta forma acurácia do sistema como um todo.

Da mesma forma, que discutido na página anterior, quando todos os produtos de uma UEN não possuem Custos e Despesas Fixas Próprias, seja no Nível-1 ou no Nível-2 (apresentados na Figura-5.1), o GAO da UEN pode ser calculado a partir da seguinte equação:

$$
G A O_{U E N_{k}}=\frac{\sum_{j=1}^{n} \sum_{i=1}^{m} M B C_{i j}}{R E S_{U E N-k}}=\frac{M B C T_{K}}{R E S_{U E N-k}} \text {, onde } M B C T_{k} \text { é a Margem bruta de }
$$

contribuição total da $U E N_{k}$.

\subsubsection{Grau de Alavancagem Operacional Combinado - GAOC}

Em uma estrutura do tipo sede administrativa com várias unidades de negócios, pode-se ainda apresentar o GAO dos Produtos/UENs em relação à Sede 
Administrativa que, nesse caso, é chamado de Grau de Alavancagem Operacional Combinado (GAOC), conforme apresentado por BRUNSTEIN (2005). As equações são idênticas às do GAO, sendo que o denominador é substituído pelo Resultado da Sede Administrativa, realizando toda a análise de variação dos lucros da Sede a partir da variação das vendas dos produtos das UENs. Nesse caso o cálculo e interpretação dos resultados ocorrerão conforme apresentado abaixo:

\section{GAOC da UEN $\boldsymbol{k}$ incidente na Sede Administrativa.}

A partir da Equação-84, tem-se:

$$
\operatorname{GAOC}_{\left(U E N_{k}\right)_{S E D E}}=\frac{\sum_{j=1}^{n} \sum_{i=1}^{m} M B C_{i j}}{R E S_{\text {SEDE }}}
$$

O resultado desta operação pode ser interpretado como a variação em porcentagem dos lucros da Sede Administrativa, a partir da variação de 1\% nas vendas de todos os produtos e em todos os mercados onde a UEN $k$ comercializa seus produtos.

GAOC do Produto $i$, no mercado $j$, da UEN $k$ incidente na Sede Administrativa.

A partir da Equação-81, tem-se:

$$
\operatorname{GAOC}_{\left(P_{i j} / U E N_{k}\right)_{S E D E}}=\frac{M B C_{i j}}{R E S_{S E D E}}
$$

A equação acima também pode ser representada da seguinte forma;

$$
\begin{aligned}
& \operatorname{GAOC}_{\left(P_{i j} / U E N_{k}\right)_{S E D E}}=\frac{M B C_{i j}}{R E S_{S E D E}} \cdot \frac{R E S_{U E N-k}}{R E S_{U E N-k}} \cdot \frac{\sum_{j=1}^{n} \sum_{i=1}^{m} M B C_{i j}}{\sum_{j=1}^{n} \sum_{i=1}^{m} M B C_{i j}} ; \text { rearranjando, tem-se: } \\
& \operatorname{GAOC}_{\left(P_{i j} / U E N_{k}\right)_{S E D E}}=\frac{M B C_{i j}}{R E S_{U E N-k}} \cdot \frac{R E S_{U E N-k}}{\sum_{j=1}^{n} \sum_{i=1}^{m} M B C_{i j}} \cdot \frac{\sum_{j=1}^{n} \sum_{i=1}^{m} M B C_{i j}}{R E S_{S E D E}}
\end{aligned}
$$




$$
\operatorname{GAOC}_{\left(P_{i j} / U E N_{k}\right)_{S E D E}}=\frac{G A O_{\left(P_{i j} / U E N_{k}\right)}}{G A O_{U E N_{k}}} \cdot G A O C_{\left(U E N_{k} / S E D E\right)}
$$

O resultado desta operação pode ser interpretado como a variação em porcentagem dos lucros da Sede Administrativa, a partir da variação de 1\% nas vendas de um determinado produto em um determinado mercado onde este produto é comercializado.

\section{GAOC do Produto $\boldsymbol{i}$ da UEN $\boldsymbol{k}$ incidente na Sede Administrativa.}

A partir da Equação-83, tem-se:

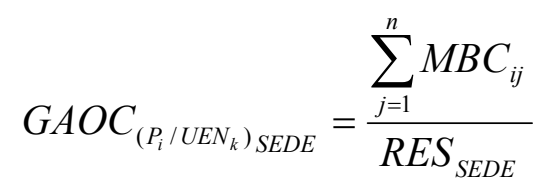

O resultado desta operação pode ser interpretado como a variação em porcentagem dos lucros da Sede Administrativa, a partir da variação de 1\% nas vendas de um determinado produto em todos os mercados onde este produto é comercializado.

Da mesma forma que apresentado no cálculo do GAO, quando os produtos não possuem Custos e Despesas Próprias nos mercados onde são comercializados a equação acima pode ser apresentada da seguinte forma:

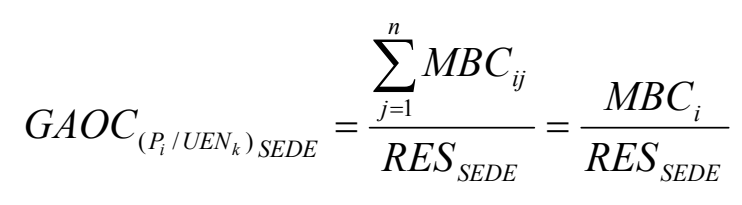

\section{GAOC da Sede Administrativa.}

Nesse caso o cálculo do GAOC pode ser realizado somando-se as Margens Brutas de Contribuição de todos os produtos, de todas as UENs, representado matematicamente da seguinte forma: 


$$
G A O C_{S E D E}=\frac{\sum_{k=1}^{p} \sum_{i=1}^{m} \sum_{j=1}^{n} M B C_{k i j}}{R E S_{S E D E}}
$$

O resultado desta operação pode ser interpretado como a variação em porcentagem dos lucros da Sede Administrativa, a partir da variação de 1\% nas vendas de todos os produtos, de todas as UENs e em todos os mercados onde estes produtos são comercializados.

\subsubsection{Margem de Segurança - MS}

Mesmo sendo o cálculo da Margem de Segurança o inverso do GAO, ela não tem as mesmas variações e possibilidades de cálculo do GAO, pois fisicamente não faz sentido calcular a Margem de Segurança de um determinado produto em um determinado mercado, ou seja, só há possibilidade de cálculo da MS para uma UEN ou para a empresa como um todo. Portanto, como $M S=1 / G A O$, devidamente apresentado no Capítulo-4, é possível calcular a Margem de Segurança da Empresa e das Unidades Estratégicas de Negócio.

A Margem de Segurança de uma UEN pode ser deduzida a partir da Equação81 do $G A O_{U E N_{k}}$, apresentada abaixo:

$$
M S_{U E N_{k}}=\frac{1}{G A O_{U E N_{k}}}=\frac{R E S_{U E N-k}}{\sum_{j=1}^{n} \sum_{i=1}^{m} M B C_{i j}}
$$

A interpretação deste indicador pode ser realizada da seguinte forma: quanto as vendas podem cair sem que haja prejuízo para a UEN em análise. Como o valor resultante da equação é dado em percentual, para a correta interpretação, é necessário levar em consideração que se as vendas de todos os produtos em todos os mercados caírem $M S \%$, a UEN terá lucro igual a zero; qualquer outro mix de queda de venda levará a um resultado diferente. Portanto, o cálculo da Margem de Segurança deve 
ser utilizado muito mais como um indicador de referência para análise histórica do que como valor isolado para tomada de decisão, sabendo que, como apresentado no capítulo-4, quanto maior a MS, menor é o risco da empresa.

Da mesma forma, a Margem de Segurança da Sede Administrativa pode ser deduzida a partir da Equação-90 do $G A O_{U E N_{k}}$, apresentada abaixo:

$$
M S_{S E D E}=\frac{1}{G A O C_{S E D E}}=\frac{R E S_{S E D E}}{\sum_{k=1}^{p} \sum_{i=1}^{m} \sum_{j=1}^{n} M B C_{k i j}}
$$

A interpretação desse indicador é idêntico ao anterior, podendo ser realizada da seguinte forma: quanto as vendas podem cair sem que haja prejuízo para a empresa como um todo. Da mesma forma, para a correta interpretação, tem-se que levar em consideração que se as vendas de todos os produtos, de todas as UENs, em todos os mercados caírem $M S \%$, a UEN terá lucro igual à zero.

\subsubsection{Ponto de Equilíbrio}

A discussão desse item, nesse capítulo, parte do pressuposto e das conclusões realizadas no Capítulo-4, mais especificamente no item 4.1. Todas as análises realizadas levaram à conclusão de que uma empresa que produz e comercializa mais de um produto pode ter um conjunto "infinito" de pontos de equilíbrio, denominado de "conjunto de possibilidades de equilíbrio".

Esta conclusão restringe em muito a utilização do Ponto de Equilíbrio como um indicador, pois como podemos utilizar os resultados e os conceitos envolvidos para efetiva tomada de decisões? Fica claro que não se pode calcular um "Ponto de Equilíbrio Global” para uma Empresa ou UEN, e utilizá-lo como verdade unívoca, como um resultado único e verdadeiro, pois seu cálculo é dependente do mix de produção ou de vendas. 
Nesse sentido, tomando como referência a Equação-62, apresentada no Capítulo-4, pode-se calcular um Ponto de Equilíbrio Global para uma UEN a partir da Margem de Segurança, como mostrado abaixo:

$$
\begin{aligned}
& Q e_{U E N-k}=Q_{\text {Total }} \cdot\left(1-M S_{U E N-k}\right) \\
& \text { sendo que: } M S_{U E N_{k}}=\frac{1}{G A O_{U E N_{k}}}=\frac{R E S_{U E N-k}}{\sum_{j=1}^{n} \sum_{i=1}^{m} M B C_{i j}}
\end{aligned}
$$

Essa equação mostra um dos pontos de equilíbrio possíveis para uma UEN e este resultado pode ser utilizado, com muito critério e limitação, somente como um valor de referência para tomada de decisões. O gestor deve ter em mente que esse ponto de equilíbrio calculado poderá ocorrer se e somente se, não for alterado o mix de produção em que a Margem de Segurança foi calculada e, para qualquer outro mix, provavelmente o valor desse Ponto de Equilíbrio Global não será verdadeiro.

Da mesma forma, pode-se calcular o Ponto de Equilíbrio Global para a Sede Administrativa. Esse indicador faz pouco ou nenhum sentido pois deve levar em conta todas as UENs da empresa, mostrando em apenas um indicador, o ponto de equilíbrio da soma de todos os produtos, de todos os mercados de todas as UENs da empresa sede, além de poder ser alterado a partir das possibilidades de variação de mix de produtos envolvidos. Essa análise não será realizada nessa Tese.

Por outro lado, o cálculo do Ponto de Equilíbrio para um determinado produto em um determinado mercado, quando há a existência de Custos e Despesas Fixas Próprias no Nível-1 (Figura-5.1), torna-se de fundamental importância, pois apresenta a quantidade mínima necessária a ser vendida para que este produto comece a apresentar uma Margem Semi-Bruta de Contribuição positiva.

Portanto, a partir da Equação-31, pode-se apresentar uma expressão para estes casos, conforme apresentado abaixo:

$$
Q e_{\left(P_{i j} / U E N_{K}\right)}=\frac{C D F_{i j}}{M B C u_{i j}}
$$


O resultado da equação anterior mostra a quantidade mínima a ser vendida de um produto em um determinado mercado para que a existência desse produto seja viável e que o produto possa contribuir positivamente para a empresa.

\subsection{CONSIDERAÇÕES SOBRE A ANÁLISE DO GAO E DO GAOC}

A análise parte do princípio que para o cálculo do GAO e do GAOC é necessário, de forma bastante simplista, a Margem de Contribuição e o Resultado, seja da UEN ou da SEDE.

De forma distinta, a Margem de Contribuição e o Resultado podem ser positivos ou negativos, conforme apresentado na Figura 5.3, abaixo:

\begin{tabular}{|c|cc|cc|}
\cline { 2 - 4 } \multicolumn{1}{c|}{} & \multicolumn{2}{c|}{ Resultado +} & \multicolumn{2}{c|}{ Resultado - } \\
\hline MBC + & $\mathbf{1}$ & $\begin{array}{c}\text { GAO }+ \\
\text { GAOC }+\end{array}$ & $\mathbf{2}$ & $\begin{array}{c}\text { GAO - } \\
\text { GAOC - }\end{array}$ \\
\hline MBC - & $\mathbf{3}$ & $\begin{array}{c}\text { GAO - } \\
\text { GAOC - }\end{array}$ & $\mathbf{4}$ & $\begin{array}{c}\text { GAO + } \\
\text { GAOC + }\end{array}$ \\
\hline
\end{tabular}

Figura 5.3 - Possíveis sinais para o GAO e o GAOC.

Abaixo a interpretação para estes casos:

Resultado 1: este é o resultado comum, apresentado até agora, representa o aumento dos lucros a partir do aumento de $1 \%$ das vendas.

Resultado 2: representa a redução do prejuízo a partir do aumento de $1 \%$ das vendas.

Resultado 3: representa a redução dos lucros a partir do aumento de $1 \%$ das vendas.

Resultado 4: representa o aumento do prejuízo a partir do aumento de $1 \%$ das vendas. 


\subsection{EXEMPLO NUMÉRICO}

O exemplo que se segue corresponde à continuação do exemplo apresentado no item 3.6, do Capítulo-3. Objetiva-se apresentar as demonstrações desenvolvidas com valores numéricos, utilizando para apresentação da resolução a metodologia apresentada por BRUNSTEIN (1987) "Representação Esquemática do Modelo Econômico da Empresa".

Então, suponha que uma empresa tenha Sede Administrativa com um total de Despesas Fixas $\left(\mathrm{CDF}_{\mathrm{SEDE}}\right)$ de $\mathrm{R} \$ 5.000,00$; uma UEN-1 com apenas dois produtos vendidos em três mercados diferentes, com $\mathrm{R} \$ 15.000,00$ de Despesas Fixas Gerais $\left(\mathrm{CDF}_{\mathrm{UEN}-1}\right)$ e, uma UEN-2, com três produtos vendidos em dois mercados diferentes, com R \$6.000,00 de Despesas Fixas Gerais $\left(\mathrm{CDF}_{\mathrm{UEN}-2}\right)$, nas seguintes condições:

Tabela 5.1 - Dados referentes aos produtos 1 e 2 da UEN-1

\begin{tabular}{|l|c|c|c|c|c|c|c|c|}
\hline \multirow{2}{*}{ Produtos } & \multicolumn{9}{|c|}{ Produto 1 } & \multicolumn{5}{c|}{ Produto 2 } \\
\cline { 2 - 9 } Mercados & $P V_{l j}$ & $D P F_{l j}$ & $Q_{1 j}$ & $C D F_{1 j}$ & $P V_{2 j}$ & $D P F_{2 j}$ & $Q_{2 j}$ & $C D F_{2 j}$ \\
\hline Mercado 1 & 55,00 & 11,00 & 200 & 0 & 88,00 & 17,00 & 180 & 0 \\
\hline Mercado 2 & 53,00 & 9,00 & 350 & $4.000,00$ & 86,00 & 15,00 & 110 & $4.500,00$ \\
\hline Mercado 3 & 54,00 & 8,00 & 180 & 500,00 & 86,00 & 14,00 & 230 & $1.200,00$ \\
\hline$C V M_{1}=13,00$ & $C D F_{I}=3.000,00$ & & \multicolumn{7}{c}{$C V M_{2}=43,00 \quad C D F_{2}=2.000,00$} \\
\hline
\end{tabular}

Tabela 5.2 - Dados referentes aos produtos 1, 2 e 3 da UEN-2

\begin{tabular}{|c|c|c|c|c|c|c|c|c|c|c|c|c|}
\hline \multirow{2}{*}{ Mercados } & \multicolumn{4}{|c|}{ Produto 1} & \multicolumn{4}{|c|}{ Produto 2} & \multicolumn{4}{|c|}{ Produto 3} \\
\hline & $\mathrm{PV}_{1 \mathrm{i}}$ & $\mathrm{DPF}_{1 \mathrm{i}}$ & $\mathrm{Q}_{1 \mathrm{i}}$ & $\mathrm{CDF}_{1 \mathrm{i}}$ & $\mathrm{PV}_{2 \mathrm{i}}$ & $\mathrm{DPF}_{2 \mathrm{i}}$ & $\mathrm{Q}_{2 \mathrm{i}}$ & $\mathrm{CDF}_{2 \mathrm{i}}$ & $\mathrm{PV}_{3 \mathrm{j}}$ & $\mathrm{DPF}_{3 \mathrm{i}}$ & $\mathrm{Q}_{3 \mathrm{i}}$ & $\mathrm{CDF}_{3 \mathrm{j}}$ \\
\hline Mercado 1 & 41,00 & 00 & 400 & $1.000,00$ & 60,00 & 12,00 & 190 & 0 & 98,00 & 20,00 & 150 & 0 \\
\hline Mercado 2 & 45,00 & 8,00 & 380 & $2.500,00$ & 60,00 & 10,00 & 150 & $4.500,00$ & 91,00 & 16,00 & 80 & $1.500,00$ \\
\hline \multicolumn{5}{|c|}{$\mathrm{CVM}_{1}=22,00$} & \multicolumn{4}{|c|}{$\mathrm{CVM}_{2}=43,00 \mathrm{CDF}_{2}=3.000,00$} & \multicolumn{4}{|c|}{$\mathrm{CVM}_{3}=48,00 \mathrm{CDF}_{3}=1.800,00$} \\
\hline
\end{tabular}




\subsubsection{Resolução Inicial}

Para a resolução do exemplo será utilizada a Representação Esquemática do Modelo Econômico da Empresa apresentado por BRUNSTEIN (1987) na Figura-5.4 e 5.5. Abaixo, para uma análise preliminar, está apresentado as Margens de Contribuição unitárias de todos os produtos nos seus respectivos mercados.

Tabela 5.3 - Cálculo da Margem de Contribuição unitária dos produtos para cada mercado da UEN-1

\begin{tabular}{|l|c|c|c|c|c|c|}
\hline \multirow{2}{*}{ Produtos } & \multicolumn{3}{|c|}{ Produto 1 } & \multicolumn{3}{c|}{ Produto 2 } \\
\cline { 2 - 7 } Itens & Mercado 1 & Mercado 2 & Mercado 3 & Mercado 1 & Mercado 2 & Mercado 3 \\
\hline$(+) \mathrm{PV}_{\mathrm{ij}}$ & 55,00 & 53,00 & 54,00 & 88,00 & 86,00 & 86,00 \\
\hline$(-) \mathrm{DPF}_{\mathrm{ij}}$ & $(11,00)$ & $(9,00)$ & $(8,00)$ & $(17,00)$ & $(15,00)$ & $(14,00)$ \\
\hline$(-) \mathrm{CVM}_{\mathrm{i}}$ & $(13,00)$ & $(13,00)$ & $(13,00)$ & $(43,00)$ & $(43,00)$ & $(43,00)$ \\
\hline$(=) \mathbf{M B C u}_{\mathrm{ij}}$ & $\mathbf{3 1 , 0 0}$ & $\mathbf{3 1 , 0 0}$ & $\mathbf{3 3 , 0 0}$ & $\mathbf{2 8 , 0 0}$ & $\mathbf{2 8 , 0 0}$ & $\mathbf{2 9 , 0 0}$ \\
\hline
\end{tabular}

Tabela 5.4 - Cálculo da Margem de Contribuição unitária dos produtos para cada mercado da UEN-2

\begin{tabular}{|l|c|c|c|c|c|c|}
\hline \multirow{2}{*}{ Itens } & \multicolumn{2}{|c|}{ Produtos } & \multicolumn{2}{c|}{ Produto 2 } & \multicolumn{2}{c|}{ Produto 3 } \\
\cline { 2 - 7 } & Mercado 1 & Mercado 2 & Mercado 1 & Mercado 2 & Mercado 1 & Mercado 2 \\
\hline$(+) \mathrm{PV}_{\mathrm{ij}}$ & 41,00 & 41,00 & 60,00 & 60,00 & 98,00 & 91,00 \\
\hline$(-) \mathrm{DPF}_{\mathrm{ij}}$ & $(9,00)$ & $(8,00)$ & $(12,00)$ & $(10,00)$ & $(20,00)$ & $(16,00)$ \\
\hline$(-) \mathrm{CVM}_{\mathrm{i}}$ & $(22,00)$ & $(22,00)$ & $(2800)$ & $(28,00)$ & $(48,00)$ & $(48,00)$ \\
\hline$(=) \mathbf{M B C u}_{\mathbf{i j}}$ & $\mathbf{1 0 , 0 0}$ & $\mathbf{1 5 , 0 0}$ & $\mathbf{2 0 , 0 0}$ & $\mathbf{2 2 , 0 0}$ & $\mathbf{3 0 , 0 0}$ & $\mathbf{2 7 , 0 0}$ \\
\hline
\end{tabular}

\subsubsection{Análise dos Resultados da UEN-1}

Em primeira análise, sem a identificação dos Indicadores de Posição Econômica, pode-se ver a UEN sob a ótica do Custeio Direto, analisando a composição e proporcionalidades dos Custos e Despesas Fixas, das Margens de Contribuição dos Produtos, tanto a unitária quanto a total. 
Portanto, sob esta ótica, ao decidir sobre qual produto merece maior incentivo às vendas, a análise da margem de contribuição unitária oferece a condição necessária, segundo a ordem de classificação decrescente.

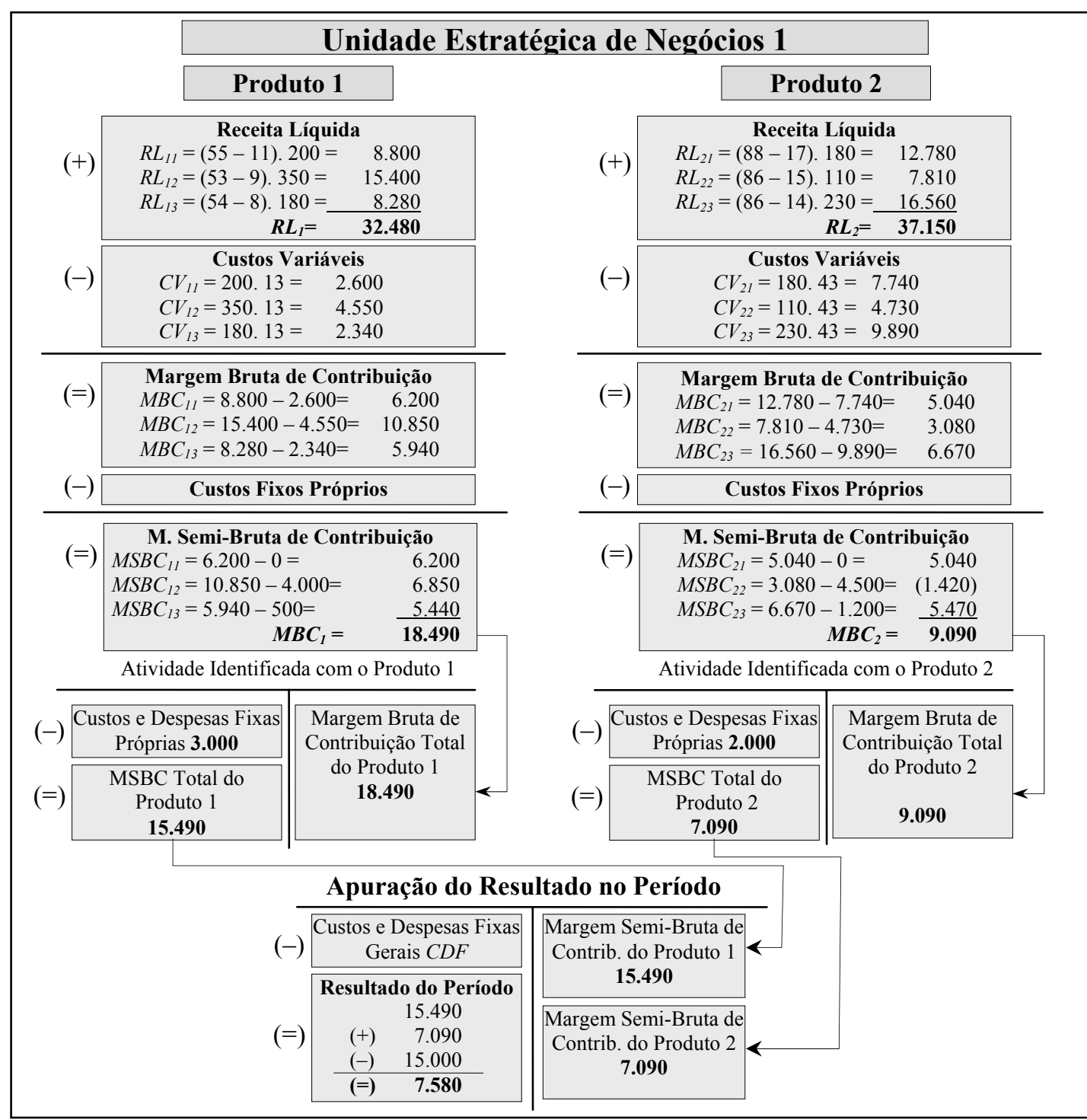

Figura 5.4 - Resultado da UEN-1 utilizando Representação Esquemática do Modelo Econômico.

Analisando a Tabela 5.3, pode-se perceber que quanto mais Produto-1 for vendido, maior será a margem de contribuição global obtida e mais facilmente serão cobertos todos os custos e despesas fixas da empresa e, conseqüentemente, maior será o Resultado do período, mesmo que este produto tenha um preço de venda 
menor do que o Produto-2. Isto porque o Produto-1 colabora com uma Margem de Contribuição unitária maior do que o Produto-2. Mesmo assim, o esforço de venda deve ser feito para o Produto-1 no Mercado-3, pois é neste mercado onde a contribuição é maior, ou seja, cada unidade vendida a mais do Produto-1 no Mercado-3 aumenta o resultado desta UEN em R\$33,00.

Esta linha de raciocínio não nos leva a descartar, em primeira análise, qualquer dos produtos em função da rentabilidade, pois todos apresentam Margem de Contribuição positiva, conferindo-nos, tão somente, uma idéia da rentabilidade a partir do aumento unitário no volume de vendas e o poder de decisão quanto a vendas e estímulo de vendas.

\section{Grau de Alavancagem Operacional}

Conforme análise dos indicadores abaixo, o GAO do Produto-1 é maior no Mercado-2, pois a cada $1 \%$ de aumento nas vendas o resultado da UEN-1 irá aumentar em 1,43\%. Essa análise vai de encontro com a análise da Margem de Contribuição Unitária, realizada no parágrafo anterior, onde mostra que a $\mathrm{MBCu}$ do Produto-1 é maior no Mercado-3, indicando-o como a melhor opção de investimento em aumento de vendas. Essa diferença é causada porque a análise da MBC é realizada em termos unitários e o GAO em termos relativos.

Abaixo está apresentado o cálculo do GAO de todos os produtos da UEN-1 para todos os mercados onde eles são comercializados.

$$
\begin{aligned}
& G A O_{\left(P_{11} / U E N_{1}\right)}=\frac{M B C_{11}}{R E S_{U E N-1}}=\frac{6.200}{7.580}=0,82 \\
& G A O_{\left(P_{12} / U E N_{1}\right)}=\frac{M B C_{12}}{R E S_{U E N-1}}=\frac{10.850}{7.580}=1,43 \\
& G A O_{\left(P_{13} / U E N_{1}\right)}=\frac{M B C_{13}}{R E S_{U E N-1}}=\frac{5.940}{7.580}=0,78 \\
& G A O_{\left(P_{21} / U E N_{1}\right)}=\frac{M B C_{21}}{R E S_{U E N-1}}=\frac{5.040}{7.580}=0,66
\end{aligned}
$$




$$
\begin{aligned}
& G A O_{\left(P_{22} / U E N_{1}\right)}=\frac{M B C_{22}}{R E S_{U E N-1}}=\frac{3.080}{7.580}=0,41 \\
& G A O_{\left(P_{23} / U E N_{1}\right)}=\frac{M B C_{23}}{R E S_{U E N-1}}=\frac{6.670}{7.580}=0,88
\end{aligned}
$$

Nessa mesma linha de raciocínio, pode-se analisar o GAO por produto conforme abaixo, confirmando que o aumento nas vendas do Produto-1 torna a empresa mais rentável pois, aumentando as vendas desse produto em $1 \%$ em todos os mercados em que é vendido, o resultado da empresa irá aumentar em 3,03\%. Em contrapartida, se o Produto-2 sofrer um aumento de $1 \%$ nas vendas, o resultado da UEN-1 irá aumentar apenas em 1,95\%.

$$
G A O_{\left(P_{1} / U E N_{1}\right)}=\frac{M B C_{1}}{R E S_{U E N-1}}=\frac{\sum_{j=1}^{3} M B C_{1 j}}{R E S_{U E N-1}}=\frac{6.200+10.850+5.940}{7.580}=3,03
$$

É possível calcular o GAO do Produto-1 somando-se os GAOs calculados para todos os mercados onde ele é vendido, da seguinte forma:

$$
\begin{aligned}
& G A O_{\left(P_{1} / U E N_{1}\right)}=0,82+1,43+0,78=3,03 \\
& G A O_{\left(P_{2} / U E N_{1}\right)}=\frac{M B C_{2}}{R E S_{U E N-1}}=\frac{\sum_{j=1}^{3} M B C_{2 j}}{R E S_{U E N-1}}=\frac{5.040+3.080+6.670}{7.580}=1,95
\end{aligned}
$$

Da mesma forma, o GAO do Produto-2, pode ser calculado conforme abaixo:

$$
G A O_{\left(P_{2} / U E N_{1}\right)}=0,66+0,41+0,88=1,95
$$

Por outro lado, se todos os produtos, em todos os mercados, sofrerem um aumento de $1 \%$ nas vendas, a UEN-1 terá um aumento nas vendas de 4,98\%, conforme calculado abaixo: 


$$
\begin{aligned}
& G A O_{U E N_{1}}=\frac{\sum_{j=1}^{3} \sum_{i=1}^{2} M B C_{i j}}{R E S_{U E N-1}}=\frac{6.200+10.850+5.940+5.040+3.080+6.670}{7.580}=4,98 \\
& G A O_{U E N_{1}}=G A O_{\left(P_{1} / U E N_{1}\right)}+G A O_{\left(P_{2} / U E N_{1}\right)}=3,03+1,95=4,98
\end{aligned}
$$

\section{Margem de Segurança}

A partir da Equação-92, será calculada a Margem de Segurança da UEN-1.

$$
M S_{U E N_{k}}=\frac{1}{G A O_{U E N_{k}}}=\frac{1}{4,98 \%}=20,08
$$

Este resultado mostra que com uma redução de até $20,8 \%$ das vendas na UEN1 a empresa ainda ficará na região de lucro no gráfico de ponto de equilíbrio. Se as vendas caírem mais, a empresa estará operando em prejuízo.

\section{Ponto de Equilíbrio}

Por outro lado, ao analisar a Figura-5.4, pode-se perceber que o Produto-2, no Mercado-2, apresenta Margem Semi-Bruta de Contribuição negativa, por causa do valor do custo fixo próprio necessário para vendê-lo neste mercado. Então, como a Margem de Contribuição deste produto é positiva, devem-se estimular as vendas de modo a pagar este custo fixo, ou abandonar o Mercado-2 com este produto se as vendas não atingirem pelo menos o ponto de equilíbrio neste mercado.

Então, sob esta ótica, para valer a pena vender o Produto-2 no Mercado-2, é necessário vender pelo menos 161 unidades, para que sua margem de contribuição total possa cobrir os custos e despesas fixas próprias necessários para vendê-lo neste mercado, obtendo uma Margem Semi-Bruta de Contribuição igual a zero, sendo portanto o ponto de equilíbrio do Produto-2 no Mercado-2. 
Isto é, se for vendido menos de 161 unidades, a margem semi-bruta de contribuição é negativa, e o produto estara contribuindo negativamente para cobrir os custos e despesas fixas da UEN; se for vendido mais de 161 unidades, o efeito seria o inverso.

$$
Q e_{\left(P_{22} / U E N_{1}\right)}=\frac{C D F_{22}}{M B C u_{22}}=\frac{4.500}{28}=161 \text { unidades }
$$

Onde $Q e_{\left(P_{22} / U E N_{1}\right)}$ é a quantidade de equilíbrio de produtos vendidos do Produto2 no Mercado-2.

Pode-se calcular o Ponto de Equilíbrio Global da UEN-1, através da Equação94:

$$
\begin{aligned}
& Q e_{U E N-k}=Q_{\text {Total }} \cdot\left(1-M S_{U E N-k}\right), \text { então, tem-se: } \\
& Q e_{U E N-1}=(200+350+180+180+110+230) \cdot(1-20,08 \%) \\
& Q e_{U E N-1}=1250 \cdot(1-20,08 \%), \text { então: } \\
& Q e_{U E N-1}=999 \text { unidades }
\end{aligned}
$$

Conforme discutido neste Capítulo, esse resultado pode ser utilizado somente como referência, pois é apenas um Ponto de Equilíbrio possível.

Analisando ainda a Figura-5.4, pode-se perceber que o Produto-1 através de sua Margem Semi-Bruta de Contribuição, contribui mais do que o Produto-2 para pagar os custos e despesas fixas gerais da UEN, sendo responsável por $68,6 \%$ da $M S B C$ total gerada, capaz de pagar os $C D F$ 's da UEN, gerando um Resultado do período positivo, conforme apresentado.

\subsubsection{Análise dos Resultados da UEN-2}

Do mesmo modo que na UEN-1, se fôssemos decidir qual produto mereceria maior incentivo às vendas, poderíamos analisar primeiramente as Margens de Contribuição unitária apresentadas na Tabela 5.4, onde poderíamos perceber que 
quanto mais Produto-3 for vendido, maior será a margem de contribuição global obtida e, conseqüentemente, maior será o resultado do Período.

Neste caso, como o preço de venda do Produto-3 é mais alto e o Produto-2 possui $M B C$ relativa mais alta, deve-se avaliar o esforço de venda versus a quantidade de venda marginal, pois é mais vantajoso vender duas unidades a mais do Produto-2 que uma unidade a mais do Produto-3, porque resulta em maior $M B C$ global. Pode-se visualizar melhor este resultado a partir da análise do GAO dos produtos, por apresentar o gradiente de aumento nos lucros de forma relativa.

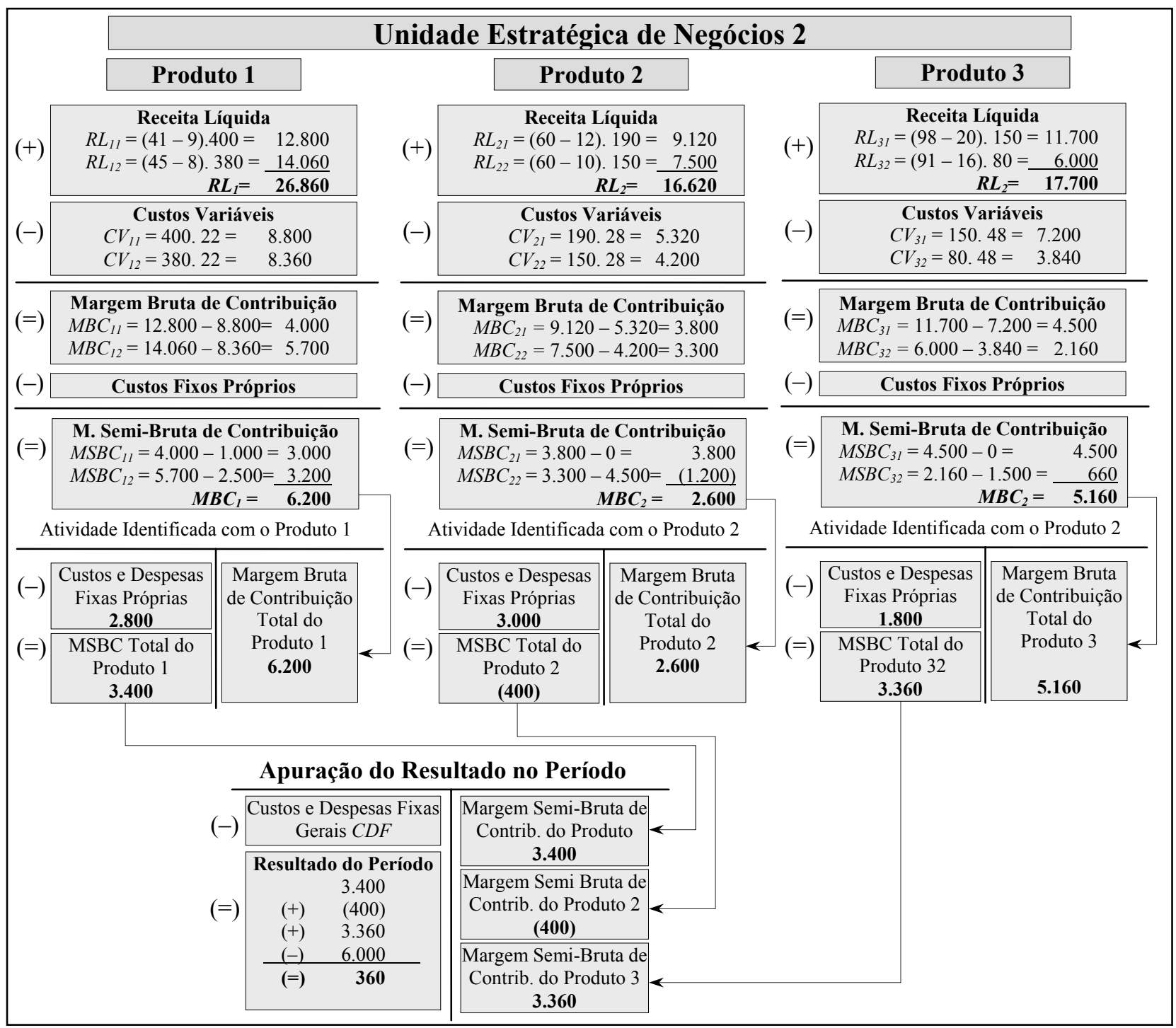

Figura 5.5 - Resultado da UEN-2 utilizando Representação Esquemática do Modelo Econômico. 
Como na UEN-1, esta linha de raciocínio não nos leva a descartar, em primeira análise, qualquer dos produtos em função da rentabilidade, pois todos apresentam Margem Bruta de Contribuição positiva. Por outro lado, ao analisarmos a Figura-5.5, podemos perceber que o Produto-2 no Mercado-2, apresenta Margem Semi-Bruta de Contribuição negativa, por causa do valor do custo fixo próprio necessário para vendê-lo neste mercado. Portanto, devem-se estimular as vendas de modo a pagar tais custos fixos ou abandonar o Mercado-2 com este produto, se as vendas não atingirem pelo menos o ponto de equilíbrio neste mercado que, para este caso, o ponto de equilíbrio é de 205 unidades.

$$
Q e_{\left(P_{22} / U E N_{1}\right)}=\frac{C D F_{22}}{M B C u_{22}}=\frac{4.500}{22}=205 \text { unidades }
$$

Com esse nível de produção o Produto-2 apresentaria uma $M S B C_{\text {Total }}$ positiva e igual a 3.800, viabilizando a venda deste produto. Por outro lado, como a $M B C_{\text {unitária }}$ do Produto-2 é maior no Mercado-2, é mais vantajoso estimular suas vendas neste mercado, obtendo-se assim, um aumento maior no resultado global da UEN. Por outro lado, faz-se necessário verificar o alto valor dos $C D F$ 's deste mercado, pois eles estão acarretando problemas nas $M S B C$ 's dos produtos, reduzindo muito as respectivas rentabilidades. Para completar esta análise, é preciso verificar o GAO e a MS desta UEN, conforme abaixo:

\section{Grau de Alavancagem Operacional}

Conforme análise dos indicadores adiante, o maior GAO é do Produto-1 no Mercado-3, seguido do Produto-3 no Mercado-1. Essa análise vai de encontro com a análise da Margem de Contribuição Unitária, onde mostra que a $\mathrm{MBCu}$ do Produto-3 é maior no Mercado-1, indicando-o como a melhor opção de investimento em aumento de vendas.

Abaixo apresentamos o cálculo do GAO de todos os produtos da UEN-1 para todos os mercados onde eles são comercializados. 


$$
\begin{aligned}
& G A O_{\left(P_{11} / U E N_{2}\right)}=\frac{M B C_{11}}{R E S_{U E N-2}}=\frac{4.000}{360}=11,11 \\
& G A O_{\left(P_{12} / U E N_{2}\right)}=\frac{M B C_{12}}{R E S_{U E N-2}}=\frac{5.700}{360}=15,83 \\
& G A O_{\left(P_{21} / U E N_{2}\right)}=\frac{M B C_{21}}{R E S_{U E N-2}}=\frac{3.800}{360}=10,55 \\
& G A O_{\left(P_{22} / U E N_{2}\right)}=\frac{M B C_{22}}{R E S_{U E N-2}}=\frac{3.300}{360}=9,17 \\
& G A O_{\left(P_{31} / U E N_{2}\right)}=\frac{M B C_{31}}{R E S_{U E N-2}}=\frac{4.500}{360}=12,50 \\
& G A O_{\left(P_{32} / U E N_{2}\right)}=\frac{M B C_{32}}{R E S_{U E N-2}}=\frac{2.160}{360}=6,00
\end{aligned}
$$

Nessa mesma linha de raciocínio, pode-se analisar o GAO por produto, conforme abaixo, confirmando que o aumento nas vendas do Produto-1 torna a empresa mais rentável, pois aumentando as vendas desse produto em $1 \%$ em todos os mercados em que é vendido, o resultado da UEN irá aumentar em 26,94\%. Em contrapartida, se o Produto-3 sofrer um aumento de $1 \%$ nas vendas, o resultado da UEN-1 irá aumentar apenas em 18,59\%, sendo a pior opção.

$$
\begin{gathered}
G A O_{\left(P_{1} / U E N_{2}\right)}=\frac{M B C_{1}}{R E S_{U E N-2}}=\frac{\sum_{j=1}^{2} M B C_{1 j}}{R E S_{U E N-2}}=\frac{4.000+5.700}{360}=26,94 \\
G A O_{\left(P_{2} / U E N_{2}\right)}=\frac{M B C_{2}}{R E S_{U E N-2}}=\frac{\sum_{j=1}^{2} M B C_{2 j}}{R E S_{U E N-2}}=\frac{3.800+3.300}{360}=19,72 \\
G A O_{\left(P_{3} / U E N_{2}\right)}=\frac{M B C_{3}}{R E S_{U E N-2}}=\frac{\sum_{j=1}^{2} M B C_{3 j}}{R E S_{U E N-2}}=\frac{4.500+2.160}{360}=18,50
\end{gathered}
$$

É possível calcular o GAO dos Produtos somando-se os GAOs calculados para todos os mercados onde ele é vendido, da seguinte forma: 


$$
\begin{aligned}
& G A O_{\left(P_{1} / U E N_{2}\right)}=G A O_{\left(P_{11} / U E N_{2}\right)}+G A O_{\left(P_{12} / U E N_{2}\right)}=11,11+15,83=26,94 \\
& G A O_{\left(P_{2} / U E N_{2}\right)}=G A O_{\left(P_{21} / U E N_{2}\right)}+G A O_{\left(P_{22} / U E N_{2}\right)}=10,55+9,17=19,72 \\
& G A O_{\left(P_{3} / U E N_{2}\right)}=G A O_{\left(P_{31} / U E N_{2}\right)}+G A O_{\left(P_{32} / U E N_{2}\right)}=12,50+6,00=18,50
\end{aligned}
$$

Por outro lado, se todos os produtos, em todos os mercados sofrerem um aumento de $1 \%$ nas vendas, a UEN-2 terá um aumento nas vendas de 65,16\%, conforme calculado abaixo:

$$
\begin{aligned}
G A O_{U E N_{2}} & =\frac{\sum_{j=1}^{2} \sum_{i=1}^{3} M B C_{i j}}{R E S_{U E N-k}}=\frac{4.000+5.700+3.800+3.300+4.500+2.160}{360}=65,16 \\
G A O_{U E N_{2}} & =G A O_{\left(P_{1} / U E N_{2}\right)}+G A O_{\left(P_{2} / U E N_{2}\right)}+G A O_{\left(P_{3} / U E N_{2}\right)} \\
G A O_{U E N_{2}} & =G 26,94+19,72+18,50=65,16
\end{aligned}
$$

O fato de todos os GAOs da UEN-2 estarem maiores do que os da UEN-1, não representa absolutamente nada, pois esta comparação somente pode ser realizada internamente pela UEN. A comparação dos produtos entre UENs pode ser feita somente pelo GAOC, que será realizada adiante, no Item-5.3.4.

\section{Margem de Segurança}

A partir da Equação-92, apresentada abaixo, será calculada a Margem de Segurança da UEN-2.

$$
M S_{U E N_{k}}=\frac{1}{G A O_{U E N_{k}}}=\frac{1}{65,16 \%}=1,53
$$

Esse resultado mostra que as vendas da UEN-1 podem cair até 1,53\% que ainda estará na região de lucro no gráfico de ponto de equilíbrio da empresa; se as vendas caírem mais, a empresa estará operando em prejuízo. Este resultado é muito lógico, pois a UEN-2 apresenta um lucro muito baixo ( $\mathrm{R} \$ 360,00)$ e, comparando 
com a Figura-4.7 (Análise da MS x GAO), confirmamos que quanto mais alto o GAO, menor a MS e, conseqüentemente maior o risco da empresa.

\section{Ponto de Equilíbrio}

O Ponto de Equilíbrio de produtos em mercados específicos faz sentido quando um determinado produto possui CFD em determinado mercado, como é o caso do Produto-2, no Mercado-2, que apresenta Margem Semi-Bruta de Contribuição negativa por causa do valor do custo fixo próprio necessário para vendê-lo neste mercado. Esta análise já foi realizada, onde foi identificado um Ponto de Equilíbrio de 205 unidades, conforme expressão apresentada na página 120.

O Ponto de Equilíbrio Global da UEN-1 pode ser calculado através da Equação94:

$$
\begin{aligned}
& Q e_{U E N-k}=Q_{T o t a l} \cdot\left(1-M S_{U E N-k}\right), \text { então, tem-se: } \\
& Q e_{U E N-1}=(400+380+190+150+150+80) \cdot(1-1,53 \%) \\
& Q e_{U E N-1}=1.350 \cdot(1-1,53 \%), \text { então: } \\
& Q e_{U E N-1}=1.329 \text { unidades }
\end{aligned}
$$

Conforme discutido neste Capítulo, este resultado pode ser utilizado somente como referência, pois é apenas um Ponto de Equilíbrio possível.

Analisando ainda a Figura-5.5, pode-se perceber que o Produto-1, através de sua Margem Semi-Bruta de Contribuição, contribui mais do que o Produto-2 e o Produto-3 para pagar os custos e despesas fixas gerais da UEN, sendo responsável por R $\$ 6.200,00$ de $M S B C$, confirmando que o aumento nas vendas deste produto é capaz de alavancar o resultado desta UEN. 


\subsubsection{Análise dos Resultados da Sede Administrativa}

Analisando o resultado da empresa na Figura-5.6, percebe-se que a empresa está operando com um resultado positivo de 2.940, sendo que o Produto-1 da UEN-1, é o melhor produto do conjunto, pois apresenta a maior margem de contribuição unitária da empresa. A UEN-1 apresenta melhor resultado pois seus produtos são mais rentáveis, mesmo tendo um CDF próprio maior.

\begin{tabular}{|c|c|c|}
\hline \multicolumn{3}{|c|}{ Apuração do Resultado da Sede Administrativa } \\
\hline$(-)$ & $\begin{array}{c}\text { Custos e Despesas Fixas } \\
\text { Gerais } C D F\end{array}$ & $\begin{array}{c}\text { Margem Semi Bruta de } \\
\text { Contrib. da UEN-1 }\end{array}$ \\
\hline$(=)$ & $\begin{array}{cc}\text { Resultado do Período } \\
& 7.580 \\
(+) & 360 \\
(-) & 5.000 \\
(=) & \mathbf{2 . 9 4 0}\end{array}$ & \begin{tabular}{|c|}
$\mathbf{7 . 5 8 0}$ \\
Margem Semi Bruta de \\
Contrib. da UEN-2 \\
$\mathbf{3 6 0}$
\end{tabular} \\
\hline
\end{tabular}

Figura 5.6 - Resolução da Sede Administrativa utilizando Representação Esquemática do Modelo Econômico.

Da mesma forma, utilizando-se das equações, é possível calcular o GAOC de cada UEN em relação à Sede Administrativa, mostrando que se a UEN-1 aumentar as vendas de todos os seus produtos em 1\%, o resultado da Sede irá aumentar em $12,85 \%$, indicando que não é possível compara os GAOs entre UENs, pois todos os GAOs da UEN-2 são maiores que os da UEN-1 e, na verdade, é vantajoso para a empresa concentrar os esforços para aumentar as vendas da UEN-1, conforme os resultados obtidos abaixo.

$$
\begin{aligned}
G_{A O C_{\left(U E N_{1}\right)_{S E D E}}}= & \frac{\sum_{j=1}^{3} \sum_{i=1}^{2} M B C_{i j}}{R E S_{\text {SEDE }}}=\frac{6.200+10.850+5.940+5.040+3.080+6.670}{2.940}=12,85 \\
\left.\operatorname{GAOC}_{\left(U E N_{2}\right)}\right)_{S E D E} & =\frac{\sum_{j=1}^{2} \sum_{i=1}^{3} M B C_{i j}}{R E S_{S E D E}}=\frac{4.000+5.700+3.800+3.300+4.500+2.160}{2.940}=7,98
\end{aligned}
$$

O cálculo do GAOC por produto/mercado confirma o resultado obtido pelo GAO das UENs, pois essas análises mostram que para a UEN-1 o aumento nas vendas do Produto-1 no Mercado-2 torna a Empresa mais lucrativa, o mesmo 
acontecendo para a UEN-2. Portanto pode-se concluir que o cálculo do GAOC por produto/mercado, conforme realizado abaixo, repete as conclusões já obtidas anteriormente, não sendo de grande valia, pois o que é melhor para cada UEN o será para a Empresa.

$$
\begin{aligned}
& \operatorname{GAOC}_{\left(P_{11} / U E N_{1}\right)_{S E D E}}=\frac{M B C_{11}}{R E S_{S E D E}}=\frac{6.200}{2.940}=2,11 \\
& \operatorname{GAOC}_{\left(P_{12} / U E N_{1}\right)_{S E D E}}=\frac{M B C_{12}}{R E S_{S E D E}}=\frac{10.850}{2.940}=3,69 \\
& \operatorname{GAOC}_{\left(P_{13} / U E N_{1}\right)_{S E D E}}=\frac{M B C_{13}}{R E S_{\text {SEDE }}}=\frac{5.940}{2.940}=2,02 \\
& \operatorname{GAOC}_{\left(P_{21} / U E N_{1}\right)_{S E D E}}=\frac{M B C_{21}}{R E S_{S E D E}}=\frac{5.040}{2.940}=1,71 \\
& \operatorname{GAOC}_{\left(P_{22} / U E N_{1}\right)_{S E D E}}=\frac{M B C_{22}}{R E S_{S E D E}}=\frac{3.080}{2.940}=1,05 \\
& \operatorname{GAOC}_{\left(P_{23} / U E N_{1}\right)_{S E D E}}=\frac{M B C_{23}}{R E S_{S E D E}}=\frac{6.670}{2.940}=2,27 \\
& \operatorname{GAOC}_{\left(P_{11} / U E N_{2}\right)_{S E D E}}=\frac{M B C_{11}}{R E S_{S E D E}}=\frac{4.000}{2.940}=1,36 \\
& \operatorname{GAOC}_{\left(P_{12} / U E N_{2}\right)_{S E D E}}=\frac{M B C_{12}}{R E S_{\text {SEDE }}}=\frac{5.700}{2.940}=1,94 \\
& \operatorname{GAOC}_{\left(P_{21} / U E N_{2}\right)} \operatorname{SEDE}=\frac{M B C_{21}}{R E S_{\text {SEDE }}}=\frac{3.800}{2.940}=1,29 \\
& \operatorname{GAOC}_{\left(P_{22} / U E N_{2}\right)_{S E D E}}=\frac{M B C_{22}}{R E S_{S E D E}}=\frac{3.300}{2.940}=1,22 \\
& \operatorname{GAOC}_{\left(\mathrm{P}_{31} / U E N_{2}\right)_{S E D E}}=\frac{M B C_{31}}{R E S_{\text {SEDE }}}=\frac{4.500}{2.940}=1,53 \\
& \operatorname{GAOC}_{\left(\mathrm{P}_{32} / U E N_{2}\right)_{S E D E}}=\frac{M B C_{32}}{R E S_{\text {SEDE }}}=\frac{2.160}{2.940}=0,73
\end{aligned}
$$




$$
\begin{aligned}
& \operatorname{GAOC}_{\left(P_{1} / U E N_{1}\right)} S E D E \\
& =\frac{M B C_{1}}{R E S_{\text {SEDE }}}=\frac{\sum_{j=1}^{3} M B C_{1 j}}{R E S_{\text {SEDE }}}=\frac{6.200+10.850+5.940}{2.940}=7,82 \\
& \operatorname{GAOC}_{\left(P_{2} / U E N_{1}\right)_{S E D E}}=\frac{M B C_{2}}{R E S_{S E D E}}=\frac{\sum_{j=1}^{3} M B C_{2 j}}{R E S_{S E D E}}=\frac{5.040+3.080+6.670}{2.940}=5,03
\end{aligned}
$$

A mesma análise do parágrafo anterior serve para a análise do GAOC por produto, mostrando os mesmos resultados do GAO, pois para as duas UENs, o Produto-1 é melhor.

$$
\begin{aligned}
& \operatorname{GAOC}_{\left(P_{1} / U E N_{2}\right)_{S E D E}}=\frac{M B C_{1}}{R E S_{S E D E}}=\frac{\sum_{j=1}^{2} M B C_{1 j}}{R E S_{S E D E}}=\frac{4.000+5.700}{2.940}=3,30 \\
& \operatorname{GAOC}_{\left(P_{2} / U E N_{2}\right)_{S E D E}}=\frac{M B C_{2}}{R E S_{S E D E}}=\frac{\sum_{j=1}^{2} M B C_{2 j}}{R E S_{S E D E}}=\frac{3.800+3.300}{2.940}=2,41 \\
& \operatorname{GAOC}_{\left(P_{3} / U E N_{2}\right)_{S E D E}}=\frac{M B C_{3}}{R E S_{S E D E}}=\frac{\sum_{j=1}^{2} M B C_{3 j}}{R E S_{S E D E}}=\frac{4.500+2.160}{2.940}=2,27
\end{aligned}
$$

Se todos os produtos de todas as UENs aumentarem $1 \%$ nas vendas em todos os mercados, a Sede Administrativa terá seu lucro aumentado em 20,83\%, conforme apresentado abaixo.

$$
\begin{gathered}
G A O C_{S E D E}=\frac{\sum_{k=1}^{p} \sum_{i=1}^{m} \sum_{j=1}^{n} M B C_{k i j}}{R E S_{S E D E}}=\frac{61.240}{2.940}=20,83 \\
G_{A O C_{S E D E}}=7,82+5,03+3,30+2,41+2,27=20,83
\end{gathered}
$$




\section{APLICAÇÃO DA METODOLOGIA EM UMA INSTITUIÇÃO DE ENSINO SUPERIOR}

A Instituição de Ensino Superior escolhida localiza-se no estado do Paraná e está no mercado a mais de quarenta anos. É constituída por uma Mantenedora e pela Mantida, sendo uma empresa privada com fins lucrativos.

Possui trinta e cinco Cursos de Graduação e três de Pós-Graduação Stricto Sensu distribuídos em cinco faculdades diferentes. Possui em torno de 10.000 alunos matriculados e um faturamento bruto anual na ordem de $\mathrm{R} \$ 75.000 .000,00$.

Os cursos de Pós-Graduação Lato Sensu são ofertados por um instituto que utiliza o nome da mantida para a certificação dos cursos. Esse instituto é considerado como uma empresa a parte da Universidade, possuindo administração própria e controle de recursos independente. O instituto foi excluído do trabalho, pois a intenção era estudar somente a Universidade; por outro lado, em caso de inclusão, o instituto poderia ser considerado uma UEN sem maiores problemas.

Para o Estudo de Caso foi considerado que toda a Reitoria e as Pró-Reitorias fazem parte da Sede Administrativa, as Faculdades como Unidades Estratégicas de Negócio, os Cursos como produtos da empresa e os períodos como Mercados. Desta forma a Universidade pode ser enquadrada no modelo apresentado, conforme pode ser visto na Figura-6.1.

Cada Faculdade possui seus cursos bem definidos e não compartilham recursos físicos com as outras, todas estão em um mesmo Campus e gozam de autonomia administrativa limitada. Possuem relacionamento direto com todas as Pró-Reitorias, devendo prestar contas das ações tomadas e seguir as diretrizes e determinações de cada área superior. 


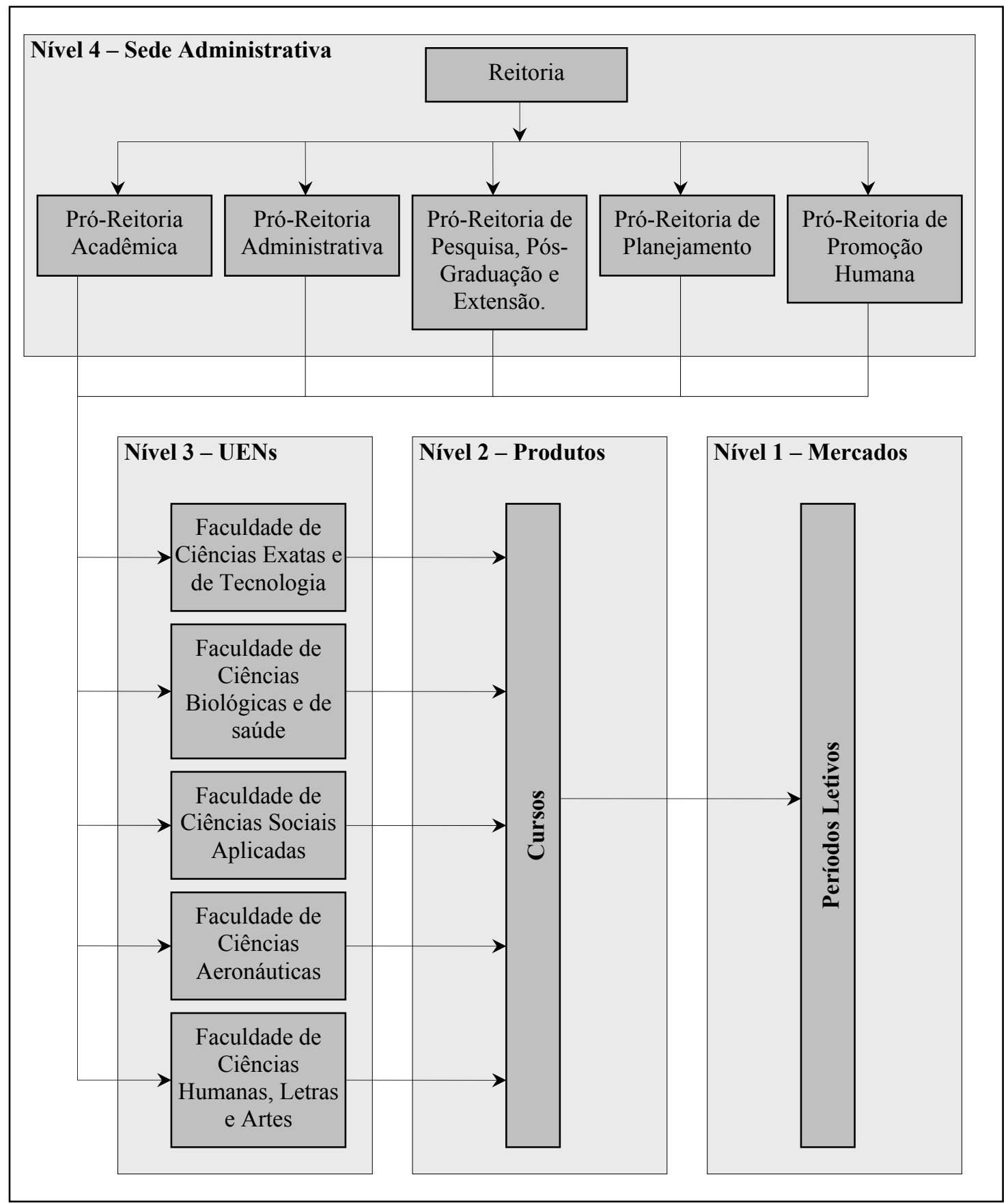

Figura 6.1 - Representação da Estrutura da Universidade conforme Modelo Apresentado.

Para a aplicação do estudo a empresa cedeu todos os dados necessários para aplicação da metodologia, para levantamento dos dados foi necessário entrevistar funcionários do departamento de Recursos Humanos, da Coordenadoria de Carreira 
Docente, os Coordenadores de Curso, Diretores de Faculdade, com objetivo de compreensão do funcionamento administrativo da empresa e do comportamento das variáveis independentes do sistema em questão.

Todas as variáveis independentes identificadas estão apresentadas nas Tabelas 6.1 a 6.6, nas Figuras de 6.1 a 6.7 a Representação Esquemática de cada UEN, bem como a aplicação do Custeio Direto. Por fim, todos os indicadores estão apresentados nas Tabelas 6.8 a 6.24 .

Deve-se observar ainda, que quando um produto (curso) não possui alunos no primeiro período significa que o curso não foi ofertado naquele período.

Tabela 6.1 - Variáveis Independentes dos Cursos da UEN-1

\begin{tabular}{|c|c|c|c|c|c|c|}
\hline \multicolumn{7}{|c|}{ UEN-1 - Faculdade de Ciências Biológicas e de Saúde } \\
\hline Cursos & \multicolumn{2}{|c|}{ Curso 1: Odontologia } & \multicolumn{2}{|c|}{ Curso 2: Fisioterapia } & \multicolumn{2}{|c|}{$\begin{array}{c}\text { Curso 3: Terapia } \\
\text { Ocupacional }\end{array}$} \\
\hline Períodos & $\begin{array}{c}Q_{l j} \\
\text { (número de } \\
\text { alunos) }\end{array}$ & $\begin{array}{l}C D F_{l j} \\
\text { (médio por } \\
\text { periodo) }\end{array}$ & $\begin{array}{c}Q_{2 j} \\
\text { (número de } \\
\text { alunos) }\end{array}$ & $\begin{array}{c}C D F_{2 j} \\
\text { (médio por } \\
\text { periodo) }\end{array}$ & $\begin{array}{c}Q_{3 j} \\
\text { (número de } \\
\text { alunos) }\end{array}$ & $\begin{array}{c}C D F_{3 j} \\
\text { (médio por } \\
\text { periodo) }\end{array}$ \\
\hline $1^{\circ}$ Ano & 60 & $30.234,00$ & 99 & $46.789,00$ & 25 & $26.957,00$ \\
\hline $2^{\circ}$ Ano & 58 & $38.344,00$ & 89 & $47.956,00$ & 14 & $36.481,00$ \\
\hline $3^{\circ}$ Ano & 53 & $45.218,00$ & 86 & $48.679,00$ & -- & -- \\
\hline $4^{\circ}$ Ano & 53 & $55.889,00$ & 79 & $50.770,00$ & -- & -- \\
\hline $5^{\circ}$ Ano & 48 & $64.800,00$ & -- & -- & -- & -- \\
\hline \multicolumn{3}{|c|}{$\begin{array}{l}P V_{l j}=1.140,00 \\
D P F_{l j}=84,36\end{array}$} & \multicolumn{2}{|c|}{$\begin{array}{l}P V_{2 j}=961,00 \\
D P F_{2 j}=71,11\end{array}$} & \multicolumn{2}{|c|}{$\begin{array}{l}P V_{3 j}=961,00 \\
D P F_{3 j}=71,11\end{array}$} \\
\hline & \multicolumn{2}{|c|}{$\begin{array}{l}C V M_{1}=10,15 \\
C D F_{1}=58.036,00\end{array}$} & \multicolumn{2}{|c|}{$\begin{array}{l}C V M_{2}=4,80 \\
C D F_{2}=47.933,00\end{array}$} & \multicolumn{2}{|c|}{$\begin{array}{l}C V M_{3}=3,60 \\
C D F_{3}=23.988,00\end{array}$} \\
\hline \multicolumn{7}{|c|}{ UEN-1 - Faculdade de Ciências Biológicas e de Saúde } \\
\hline Cursos & \multicolumn{2}{|c|}{ Curso 4: Fonoaudiologia } & \multicolumn{2}{|c|}{ Curso 5: Psicologia } & \multicolumn{2}{|c|}{$\begin{array}{l}\text { Curso 6: Medicina } \\
\text { Veterinária }\end{array}$} \\
\hline Períodos & $\begin{array}{c}Q_{4 j} \\
\text { (número de } \\
\text { alunos) }\end{array}$ & $\begin{array}{l}C D F_{4 j} \\
\text { (médio por } \\
\text { periodo) }\end{array}$ & $\begin{array}{c}Q_{5 j} \\
\text { (número de } \\
\text { alunos) }\end{array}$ & $\begin{array}{l}C D F_{5 j} \\
\text { (médio por } \\
\text { periodo) }\end{array}$ & $\begin{array}{c}Q_{6 j} \\
\text { (número de } \\
\text { alunos) }\end{array}$ & $\begin{array}{c}C D F_{6 j} \\
\text { (médio por } \\
\text { período) }\end{array}$ \\
\hline $1^{\circ}$ Ano & 14 & $25.374,00$ & 199 & $46.789,00$ & 90 & $38.546,00$ \\
\hline $2^{\circ}$ Ano & 10 & $29.163,00$ & 198 & $47.956,00$ & 83 & $40.956,00$ \\
\hline $3^{\circ}$ Ano & -- & -- & 194 & $48.679,00$ & 81 & $45.579,00$ \\
\hline $4^{\circ}$ Ano & -- & -- & 195 & $48.978,00$ & 79 & $47.975,00$ \\
\hline $5^{\circ}$ Ano & -- & -- & 197 & $49.537,00$ & 70 & $50.502,00$ \\
\hline & \multicolumn{2}{|c|}{$\begin{array}{l}P V_{4 j}=961,00 \\
D P F_{4 j}=71,11\end{array}$} & \multicolumn{2}{|c|}{$\begin{array}{l}P V_{5 j}=719,00 \\
D P F_{5 j}=53,21\end{array}$} & \multicolumn{2}{|c|}{$\begin{array}{l}P V_{6 j}=1.144,00 \\
D P F_{6 j}=84,66\end{array}$} \\
\hline & \multicolumn{2}{|c|}{$\begin{array}{l}C V M_{4}=4,20 \\
C D F_{4}=23.330,00\end{array}$} & \multicolumn{2}{|c|}{$\begin{array}{l}C V M_{5}=2,10 \\
C D F_{5}=41.758,00\end{array}$} & \multicolumn{2}{|c|}{$\begin{array}{l}C V M_{6}=11,34 \\
C D F_{6}=85.604,00\end{array}$} \\
\hline
\end{tabular}


Tabela 6.1 - Continuação

\begin{tabular}{|c|c|c|c|c|c|c|}
\hline \multicolumn{7}{|c|}{ UEN-1 - Faculdade de Ciências Biológicas e de Saúde } \\
\hline Cursos & \multicolumn{2}{|c|}{ Curso 7: Educação Física } & \multicolumn{2}{|c|}{ Curso 8: Farmácia } & \multicolumn{2}{|c|}{$\begin{array}{c}\text { Curso 9: Ciências } \\
\text { Biológicas }\end{array}$} \\
\hline Períodos & $\begin{array}{c}Q_{7 i} \\
\text { (número de } \\
\text { alunos) }\end{array}$ & $\begin{array}{c}C D F_{7 j} \\
\text { (médio por } \\
\text { periodo) }\end{array}$ & $\begin{array}{c}Q_{8 j} \\
\text { (número de } \\
\text { alunos) }\end{array}$ & $\begin{array}{c}C D F_{8 j} \\
\text { (médio por } \\
\text { periodo) }\end{array}$ & $\begin{array}{c}Q_{9_{j}} \\
\text { (número de } \\
\text { alunos) }\end{array}$ & $\begin{array}{c}C D F_{9 j} \\
\text { (médio por } \\
\text { periodo) }\end{array}$ \\
\hline $1^{\circ}$ Ano & 140 & $54.639,00$ & 46 & $19.325,00$ & 44 & $23.900,00$ \\
\hline $2^{\circ}$ Ano & 118 & $43.956,00$ & 38 & $22.967,00$ & 38 & $27.467,00$ \\
\hline $3^{\circ}$ Ano & 93 & $45.194,00$ & 23 & $25.650,00$ & 30 & $33.277,00$ \\
\hline $4^{\circ}$ Ano & -- & -- & 19 & $28.668,00$ & -- & -- \\
\hline $5^{\circ}$ Ano & -- & -- & -- & -- & -- & -- \\
\hline \multicolumn{3}{|c|}{$\begin{array}{l}P V_{7 j}=629,00 \\
D P F_{7 j}=46,55\end{array}$} & \multicolumn{2}{|c|}{$\begin{array}{l}P V_{8 j}=963,00 \\
D P F_{8 j}=71,26\end{array}$} & \multicolumn{2}{|c|}{$\begin{array}{l}P V_{9 j}=629,00 \\
D P F_{9 j}=46,55\end{array}$} \\
\hline & \multicolumn{2}{|c|}{$\begin{array}{l}C V M_{7}=2,34 \\
C D F_{7}=58.724,00\end{array}$} & \multicolumn{2}{|c|}{$\begin{array}{l}C V M_{8}=4,57 \\
C D F_{8}=27.361,00\end{array}$} & \multicolumn{2}{|c|}{$\begin{array}{l}C V M_{9}=4,65 \\
C D F_{9}=27.917,00\end{array}$} \\
\hline \multicolumn{7}{|c|}{ UEN-1 - Faculdade de Ciências Biológicas e de Saúde } \\
\hline Cursos & \multicolumn{2}{|c|}{ Curso 10: Nutrição } & \multicolumn{2}{|c|}{ Curso 11: Enfermagem } & \multicolumn{2}{|c|}{ Curso 12: Mestrado } \\
\hline Períodos & $\begin{array}{c}Q_{10 j} \\
\text { (número de } \\
\text { alunos) }\end{array}$ & $\begin{array}{l}C D F_{10 j} \\
\text { (médio por } \\
\text { periodo) }\end{array}$ & $\begin{array}{c}Q_{11 j} \\
\text { (número de } \\
\text { alunos) }\end{array}$ & $\begin{array}{c}C D F_{11 j} \\
\text { (médio por } \\
\text { período) }\end{array}$ & $\begin{array}{c}Q_{12 j} \\
\text { (número de } \\
\text { alunos) }\end{array}$ & $\begin{array}{l}C D F_{12 j} \\
\text { (médio por } \\
\text { período) }\end{array}$ \\
\hline $1^{\mathrm{o}}$ Ano & 41 & $15.143,00$ & 96 & $29.175,00$ & 25 & 0,00 \\
\hline $2^{\circ}$ Ano & 33 & $18.795,00$ & 85 & $31.695,00$ & 25 & 0,00 \\
\hline $3^{\circ}$ Ano & 24 & $22.987,00$ & 79 & $33.643,00$ & -- & -- \\
\hline $4^{\circ}$ Ano & 13 & $24.368,00$ & 62 & $34.922,00$ & -- & -- \\
\hline $5^{\circ}$ Ano & -- & -- & -- & -- & -- & -- \\
\hline \multicolumn{3}{|c|}{$\begin{array}{l}P V_{10 j}=809,00 \\
D P F_{10 j}=59,87\end{array}$} & \multicolumn{2}{|c|}{$\begin{array}{l}P V_{11 j}=629,00 \\
D P F_{1 j}=46,55\end{array}$} & \multicolumn{2}{|c|}{$\begin{array}{l}P V_{12 j}=860,00 \\
D P F_{12 j}=63,64\end{array}$} \\
\hline & \multicolumn{2}{|c|}{$\begin{array}{l}C V M_{10}=5,76 \\
C D F_{10}=25.267,00\end{array}$} & \multicolumn{2}{|c|}{$\begin{array}{l}C V M_{11}=8,98 \\
C D F_{11}=23.904,00\end{array}$} & \multicolumn{2}{|c|}{$\begin{array}{l}C V M_{12}=6,32 \\
C D F_{12}=143.730,00\end{array}$} \\
\hline
\end{tabular}


Tabela 6.2 - Variáveis Independentes dos Cursos da UEN-2

\begin{tabular}{|c|c|c|c|c|c|c|}
\hline \multicolumn{7}{|c|}{ UEN-2 - Faculdade de Ciências Sociais Aplicadas } \\
\hline Cursos & \multicolumn{2}{|c|}{ Curso 1: Administração } & \multicolumn{2}{|c|}{$\begin{array}{l}\text { Curso 2: Ciências } \\
\text { Econômicas }\end{array}$} & \multicolumn{2}{|c|}{ Curso 3: Ciências Contábeis } \\
\hline Períodos & $\begin{array}{c}Q_{l j} \\
\text { (número de } \\
\text { alunos) }\end{array}$ & $\begin{array}{c}C D F_{1 j} \\
\text { (médio por } \\
\text { periodo) }\end{array}$ & $\begin{array}{c}Q_{2 j} \\
\text { (número de } \\
\text { alunos) }\end{array}$ & $\begin{array}{c}C D F_{2 j} \\
\text { (médio por } \\
\text { periodo) }\end{array}$ & $\begin{array}{c}Q_{3 j} \\
\text { (número de } \\
\text { alunos) }\end{array}$ & $\begin{array}{c}C D F_{3 j} \\
\text { (médio por } \\
\text { período) }\end{array}$ \\
\hline $1^{\circ}$ Ano & 428 & $88.500,00$ & -- & -- & 85 & $16.348,00$ \\
\hline $2^{\circ}$ Ano & 346 & $74.900,00$ & 25 & $7.250,00$ & 67 & $16.397,00$ \\
\hline $3^{\circ}$ Ano & 335 & $68.100,00$ & 14 & $7.130,00$ & 49 & $10.232,00$ \\
\hline $4^{\circ}$ Ano & 275 & $63.600,00$ & 23 & $7.875,00$ & 38 & $9.928,00$ \\
\hline & \multicolumn{2}{|c|}{$\begin{array}{l}P V_{l j}=487,00 \\
D P F_{l j}=36,04\end{array}$} & \multicolumn{2}{|c|}{$\begin{array}{l}P V_{2 j}=440,00 \\
D P F_{2 j}=32,56\end{array}$} & \multicolumn{2}{|c|}{$\begin{array}{l}P V_{3 j}=440,00 \\
D P F_{3 j}=32,56\end{array}$} \\
\hline & \multicolumn{2}{|c|}{$\begin{array}{l}C V M_{1}=0,00 \\
C D F_{1}=55.253,00\end{array}$} & \multicolumn{2}{|c|}{$\begin{array}{l}C V M_{2}=0,00 \\
C D F_{2}=12.765,00\end{array}$} & \multicolumn{2}{|c|}{$\begin{array}{l}C V M_{3}=0,00 \\
C D F_{3}=18.254,00\end{array}$} \\
\hline \multicolumn{7}{|c|}{ UEN-2 - Faculdade de Ciências Sociais Aplicadas } \\
\hline sos & \multicolumn{2}{|c|}{ Curso 4: Marketing } & \multicolumn{2}{|c|}{$\begin{array}{l}\text { Curso 5: Relações } \\
\text { Internacionais }\end{array}$} & \multicolumn{2}{|c|}{ Curso 6: Turismo } \\
\hline Períodos & $\begin{array}{c}Q_{4 j} \\
\text { (número de } \\
\text { alunos) }\end{array}$ & $\begin{array}{l}\mathrm{CDF}_{4 i} \\
\text { (médio por } \\
\text { periodo) }\end{array}$ & $\begin{array}{c}Q_{5 i} \\
\text { (número de } \\
\text { alunos) }\end{array}$ & $\begin{array}{l}C D F_{5 i} \\
\text { (médio por } \\
\text { periodo) }\end{array}$ & $\begin{array}{c}Q_{6 j} \\
\text { (número de } \\
\text { alunos) }\end{array}$ & $\begin{array}{l}C D F_{6 i} \\
\text { (médio por } \\
\text { periodo) }\end{array}$ \\
\hline $1^{\circ}$ Ano & 77 & $17.686,00$ & 50 & $11.967,00$ & 97 & 18.153 \\
\hline $2^{\circ}$ Ano & 69 & $15.978,00$ & 48 & $9.465,00$ & 86 & 17.879 \\
\hline $3^{\circ}$ Ano & 43 & $11.341,00$ & 45 & $10.572,00$ & 69 & 16.568 \\
\hline $4^{\circ}$ Ano & 48 & $10.978,00$ & 46 & $10.259,00$ & 67 & 16.634 \\
\hline & \multicolumn{2}{|c|}{$\begin{array}{l}P V_{4 j}=487,00 \\
D P F_{4 j}=36,04\end{array}$} & \multicolumn{2}{|c|}{$\begin{array}{l}P V_{5 j}=488,00 \\
D P F_{5 j}=36,11\end{array}$} & \multicolumn{2}{|c|}{$\begin{array}{l}P V_{6 j}=493,00 \\
D P F_{6 j}=36,48\end{array}$} \\
\hline & \multicolumn{2}{|c|}{$\begin{array}{l}C V M_{4}=0,00 \\
C D F_{4}=17.234\end{array}$} & \multicolumn{2}{|c|}{$\begin{array}{l}C V M_{5}=0,00 \\
C D F_{5}=17.100,00\end{array}$} & \multicolumn{2}{|c|}{$\begin{array}{l}C V M_{6}=0,00 \\
C D F_{6}=22.235,00\end{array}$} \\
\hline \multicolumn{7}{|c|}{ UEN-2 - Faculdade de Ciências Sociais Aplicadas } \\
\hline Cursos & \multicolumn{2}{|c|}{$\begin{array}{c}\text { Curso 7: Comunicação } \\
\text { Social } \\
\end{array}$} & \multicolumn{2}{|c|}{$\begin{array}{c}\text { Curso 8: Secretariado } \\
\text { Executivo }\end{array}$} & \multicolumn{2}{|c|}{ Curso 9: Mestrado } \\
\hline Períodos & $\begin{array}{c}Q_{7 i} \\
\text { (número de } \\
\text { alunos) }\end{array}$ & $\begin{array}{c}C D F_{7 j} \\
\text { (médio por } \\
\text { periodo) }\end{array}$ & $\begin{array}{c}Q_{8 i} \\
\text { (número de } \\
\text { alunos) }\end{array}$ & $\begin{array}{c}C D F_{8 j} \\
\text { (médio por } \\
\text { periodo) }\end{array}$ & $\begin{array}{c}Q_{9_{j}} \\
\text { (número de } \\
\text { alunos) }\end{array}$ & $\begin{array}{c}C D F_{9 j} \\
\text { (médio por } \\
\text { período) }\end{array}$ \\
\hline $1^{\circ}$ Ano & 359 & $74.890,00$ & -- & -- & 30 & 0,00 \\
\hline $2^{\circ}$ Ano & 251 & $63.912,00$ & -- & -- & 29 & 0,00 \\
\hline $3^{\circ}$ Ano & 210 & $54.891,00$ & 28 & $7.716,00$ & -- & -- \\
\hline $4^{\circ}$ Ano & 176 & $52.934,00$ & 17 & $7.946,00$ & -- & -- \\
\hline & \multicolumn{2}{|c|}{$\begin{array}{l}P V_{7 j}=569,00 \\
D P F_{7 j}=42,11\end{array}$} & \multicolumn{2}{|c|}{$\begin{array}{l}P V_{8 j}=350,00 \\
D P F_{8 j}=25,90\end{array}$} & \multicolumn{2}{|c|}{$\begin{array}{l}P V_{9 j}=860,00 \\
D P F_{9 j}=63,64\end{array}$} \\
\hline & \multicolumn{2}{|c|}{$\begin{array}{l}C V M_{7}=0,00 \\
C D F_{7}=52.235,00\end{array}$} & \multicolumn{2}{|c|}{$\begin{array}{l}C V M_{8}=0,00 \\
C D F_{8}=12.234,00\end{array}$} & \multicolumn{2}{|c|}{$\begin{array}{l}C V M_{9}=0,00 \\
C D F_{9}=111.640,00\end{array}$} \\
\hline
\end{tabular}


Tabela 6.3 - Variáveis Independentes dos Cursos da UEN-3

\begin{tabular}{|c|c|c|c|c|c|c|}
\hline \multicolumn{7}{|c|}{ UEN-3 - Faculdade de Ciências Aeronáuticas } \\
\hline Cursos & \multicolumn{2}{|c|}{ Curso 1: Piloto Comercial } & \multicolumn{2}{|c|}{$\begin{array}{l}\text { Curso 2: Gestão de } \\
\text { Empresa Aérea }\end{array}$} & \multicolumn{2}{|c|}{$\begin{array}{l}\text { Curso 3: Tecnólogo em } \\
\text { Manutenção Aeronáutica }\end{array}$} \\
\hline Períodos & $\begin{array}{c}Q_{l j} \\
\text { (número de } \\
\text { alunos) }\end{array}$ & $\begin{array}{l}C D F_{1 j} \\
\text { (médio por } \\
\text { periodo) }\end{array}$ & $\begin{array}{c}Q_{2 j} \\
\text { (número de } \\
\text { alunos) }\end{array}$ & $\begin{array}{c}C D F_{2 j} \\
\text { (médio por } \\
\text { periodo) }\end{array}$ & $\begin{array}{c}Q_{3 j} \\
\text { (número de } \\
\text { alunos) }\end{array}$ & $\begin{array}{c}C D F_{3 j} \\
\text { (médio por } \\
\text { periodo) }\end{array}$ \\
\hline $1^{\circ}$ Ano & 87 & $18.894,00$ & 48 & $11.769,00$ & 50 & $10.982,00$ \\
\hline $2^{\circ}$ Ano & 58 & $15.014,00$ & 42 & $11.917,00$ & 45 & $9.528,00$ \\
\hline $3^{\circ}$ Ano & 47 & $13.583,00$ & 36 & $12.842,00$ & 41 & $9.681,00$ \\
\hline \multicolumn{3}{|c|}{$\begin{array}{l}P V_{l j}=629,00 \\
D P F_{l j}=46,55\end{array}$} & \multicolumn{2}{|c|}{$\begin{array}{l}P V_{2 j}=493,00 \\
D P F_{2 j}=36,48\end{array}$} & \multicolumn{2}{|c|}{$\begin{array}{l}P V_{3 j}=476,00 \\
D P F_{3 j}=35,22\end{array}$} \\
\hline & \multicolumn{2}{|c|}{$\begin{array}{l}C V M_{1}=0,00 \\
C D F_{1}=26.879,00\end{array}$} & \multicolumn{2}{|c|}{$\begin{array}{l}C V M_{2}=0,00 \\
C D F_{2}=15.769,00\end{array}$} & \multicolumn{2}{|c|}{$\begin{array}{l}C V M_{3}=0,00 \\
C D F_{3}=22.654,00\end{array}$} \\
\hline
\end{tabular}


Tabela 6.4 - Variáveis Independentes dos Cursos da UEN-4

\begin{tabular}{|c|c|c|c|c|c|c|}
\hline \multicolumn{7}{|c|}{ UEN-4 - Faculdade de Ciências Exatas e de Tecnologia } \\
\hline Cursos & \multicolumn{2}{|c|}{$\begin{array}{c}\text { Curso 1: Arquitetura e } \\
\text { Urbanismo }\end{array}$} & \multicolumn{2}{|c|}{$\begin{array}{l}\text { Curso 2: Ciência da } \\
\text { Computação }\end{array}$} & \multicolumn{2}{|c|}{ Curso 3: Design } \\
\hline Períodos & $\begin{array}{c}Q_{l j} \\
\text { (número de } \\
\text { alunos) }\end{array}$ & $\begin{array}{l}C D F_{l j} \\
\text { (médio por } \\
\text { periodo) }\end{array}$ & $\begin{array}{c}Q_{2 j} \\
\text { (número de } \\
\text { alunos) }\end{array}$ & $\begin{array}{l}C D F_{2 j} \\
\text { (médio por } \\
\text { período) }\end{array}$ & $\begin{array}{c}Q_{3 j} \\
\text { (número de } \\
\text { alunos) }\end{array}$ & $\begin{array}{l}C D F_{3 j} \\
\text { (médio por } \\
\text { periodo) }\end{array}$ \\
\hline $1^{\circ}$ Ano & 46 & $13.371,00$ & 50 & $9.782,00$ & 168 & $48.250,00$ \\
\hline $2^{\circ}$ Ano & 35 & $12.195,00$ & 47 & $9.851,00$ & 139 & $41.865,00$ \\
\hline $3^{\circ}$ Ano & 28 & $12.982,00$ & 38 & $10.908,00$ & 144 & $35.678,00$ \\
\hline $4^{\circ}$ Ano & 19 & $13.471,00$ & 17 & $10.502,00$ & 108 & $30.153,00$ \\
\hline $5^{\circ}$ Ano & 8 & $14.870,00$ & -- & -- & -- & -- \\
\hline \multicolumn{3}{|c|}{$\begin{array}{l}P V_{l j}=1.082,00 \\
D P F_{l j}=80,07\end{array}$} & \multicolumn{2}{|c|}{$\begin{array}{l}P V_{2 j}=600,00 \\
D P F_{2 j}=44,40\end{array}$} & \multicolumn{2}{|c|}{$\begin{array}{l}P V_{3 j}=520,00 \\
D P F_{3 j}=38,38\end{array}$} \\
\hline & \multicolumn{2}{|c|}{$\begin{array}{l}C V M_{1}=0,00 \\
C D F_{1}=25.453,00\end{array}$} & \multicolumn{2}{|c|}{$\begin{array}{l}C V M_{2}=0,00 \\
C D F_{2}=18.486,00\end{array}$} & \multicolumn{2}{|c|}{$\begin{array}{l}C V M_{3}=0,00 \\
C D F_{3}=42.564,00\end{array}$} \\
\hline
\end{tabular}

\begin{tabular}{|c|c|c|c|c|c|c|}
\hline \multicolumn{7}{|c|}{ UEN-4 - Faculdade de Ciências Exatas e de Tecnologia } \\
\hline Cursos & \multicolumn{2}{|c|}{ Curso 4: Engenharia Civil } & \multicolumn{2}{|c|}{$\begin{array}{c}\text { Curso 5: Engenharia } \\
\text { Mecânica }\end{array}$} & \multicolumn{2}{|c|}{$\begin{array}{l}\text { Curso 6: Engenharia } \\
\text { Elétrica }\end{array}$} \\
\hline Períodos & $\begin{array}{c}Q_{4 j} \\
\text { (número de } \\
\text { alunos) }\end{array}$ & $\begin{array}{l}C D F_{4 j} \\
\text { (médio por } \\
\text { periodo) }\end{array}$ & $\begin{array}{c}Q_{5 j} \\
\text { (número de } \\
\text { alunos) }\end{array}$ & $\begin{array}{c}C D F_{5 j} \\
\text { (médio por } \\
\text { periodo) }\end{array}$ & $\begin{array}{c}Q_{6 j} \\
\begin{array}{c}\text { (numero de } \\
\text { alunos) }\end{array}\end{array}$ & $\begin{array}{c}C D F_{6 j} \\
\text { (médio por } \\
\text { período) }\end{array}$ \\
\hline $1^{\circ}$ Ano & 45 & $12.162,00$ & 50 & $12.784,00$ & 38 & $11.946,00$ \\
\hline $2^{\circ}$ Ano & 32 & $17.906,00$ & 38 & $16.900,00$ & 25 & $15.814,00$ \\
\hline $3^{\circ}$ Ano & 22 & $17.862,00$ & 25 & $18.650,00$ & 20 & $16.503,00$ \\
\hline $4^{\circ} \mathrm{Ano}$ & 18 & $15.582,00$ & 23 & $18.361,00$ & 18 & $16.873,00$ \\
\hline $5^{\circ}$ Ano & 11 & $16.006,00$ & 15 & $17.930,00$ & 7 & $17.872,00$ \\
\hline \multicolumn{3}{|c|}{$\begin{array}{l}P V_{4 j}=1.082,00 \\
D P F_{4 j}=80,07\end{array}$} & \multicolumn{2}{|c|}{$\begin{array}{l}P V_{5 j}=1.082,00 \\
D P F_{5 j}=80,07\end{array}$} & \multicolumn{2}{|c|}{$\begin{array}{l}P V_{6 j}=1.082,00 \\
D P F_{6 j}=80,07\end{array}$} \\
\hline & \multicolumn{2}{|c|}{$\begin{array}{l}C V M_{4}=0,00 \\
C D F_{4}=28.350,00\end{array}$} & \multicolumn{2}{|c|}{$\begin{array}{l}C V M_{5}=0,00 \\
C D F_{5}=27.758,00\end{array}$} & \multicolumn{2}{|c|}{$\begin{array}{l}C V M_{6}=0,00 \\
C D F_{6}=24.406,00\end{array}$} \\
\hline
\end{tabular}

\begin{tabular}{|c|c|c|c|c|c|c|}
\hline \multicolumn{7}{|c|}{ UEN-4 - Faculdade de Ciências Exatas e de Tecnologia } \\
\hline Cursos & \multicolumn{2}{|c|}{ Curso 7: Geografia } & \multicolumn{2}{|c|}{ Curso 8: Matemática } & \multicolumn{2}{|c|}{$\begin{array}{l}\text { Curso 9: Sistemas de } \\
\text { Informação }\end{array}$} \\
\hline Períodos & $\begin{array}{c}Q_{7 j} \\
\text { (nummero de } \\
\text { alunos) }\end{array}$ & $\begin{array}{c}C D F_{7 j} \\
\text { (médio por } \\
\text { periodo) }\end{array}$ & $\begin{array}{c}Q_{8 j} \\
\text { (número de } \\
\text { alunos) }\end{array}$ & $\begin{array}{c}C D F_{8 j} \\
\text { (médio por } \\
\text { periodo) }\end{array}$ & $\begin{array}{c}Q_{9_{j}} \\
\text { (numero de } \\
\text { alunos) }\end{array}$ & $\begin{array}{c}C D F_{9 j} \\
\text { (médio por } \\
\text { periodo) }\end{array}$ \\
\hline $1^{\circ}$ Ano & -- & -- & 47 & $7.542,00$ & 46 & $9.689,00$ \\
\hline $2^{\circ}$ Ano & 34 & $9.065,00$ & 37 & $8.190,00$ & 33 & $9.241,00$ \\
\hline $3^{\circ}$ Ano & 23 & $8.997,00$ & 28 & $8.537,00$ & 19 & $9.628,00$ \\
\hline $4^{\circ}$ Ano & 8 & $9.688,00$ & 22 & $8.780,00$ & 13 & $10.241,00$ \\
\hline $5^{\circ}$ Ano & -- & -- & -- & -- & -- & -- \\
\hline \multicolumn{3}{|c|}{$\begin{array}{l}P V_{7 j}=367,00 \\
D P F_{7 j}=27,16\end{array}$} & \multicolumn{2}{|c|}{$\begin{array}{l}P V_{\delta_{j}}=367,00 \\
D P F_{8 j}=27,16\end{array}$} & \multicolumn{2}{|c|}{$\begin{array}{l}P V_{g_{j}}=600,00 \\
D P F_{9_{j}}=44,40\end{array}$} \\
\hline & \multicolumn{2}{|c|}{$\begin{array}{l}C V M_{7}=0,00 \\
C D F_{7}=15.362,00\end{array}$} & \multicolumn{2}{|c|}{$\begin{array}{l}C V M_{8}=0,00 \\
C D F_{8}=12.718,00\end{array}$} & \multicolumn{2}{|c|}{$\begin{array}{l}C V M_{9}=0,00 \\
C D F_{9}=11.917,00\end{array}$} \\
\hline
\end{tabular}


Tabela 6.5 - Variáveis Independentes dos Cursos da UEN-5

\begin{tabular}{|c|c|c|c|c|c|c|}
\hline \multicolumn{7}{|c|}{ UEN-5 - Faculdade de Ciências Humanas, Letras e Artes } \\
\hline Cursos & \multicolumn{2}{|c|}{ Curso 1: Artes Visuais } & \multicolumn{2}{|c|}{ Curso 2: História } & \multicolumn{2}{|c|}{ Curso 3: Letras } \\
\hline Períodos & $\begin{array}{c}Q_{l j} \\
\text { (número de } \\
\text { alunos) }\end{array}$ & $\begin{array}{c}C D F_{l j} \\
\text { (médio por } \\
\text { periodo) }\end{array}$ & $\begin{array}{c}Q_{2 j} \\
\text { (número de } \\
\text { alunos) }\end{array}$ & $\begin{array}{c}C D F_{2 j} \\
\text { (médio por } \\
\text { periodo) }\end{array}$ & $\begin{array}{c}Q_{3 j} \\
\text { (número de } \\
\text { alunos) }\end{array}$ & $\begin{array}{c}C D F_{3 j} \\
\text { (médio por } \\
\text { periodo) }\end{array}$ \\
\hline $1^{\circ}$ Ano & 87 & $15.019,00$ & 92 & $14.376,00$ & 89 & $13.764,00$ \\
\hline $2^{\circ}$ Ano & 68 & $16.273,00$ & 75 & $14.580,00$ & 71 & $14.527,00$ \\
\hline $3^{\circ}$ Ano & 45 & $8.902,00$ & 33 & $7.865,00$ & 47 & $7.901,00$ \\
\hline $4^{\circ}$ Ano & 33 & $8.427,00$ & 35 & $9.752,00$ & 25 & $7.637,00$ \\
\hline \multicolumn{3}{|c|}{$\begin{array}{l}P V_{l j}=367,00 \\
D P F_{1 j}=27,16\end{array}$} & \multicolumn{2}{|c|}{$\begin{array}{l}P V_{2 j}=367,00 \\
D P F_{2 j}=27,16\end{array}$} & \multicolumn{2}{|c|}{$\begin{array}{l}P V_{3 j}=367,00 \\
D P F_{3 j}=38,27,16\end{array}$} \\
\hline & \multicolumn{2}{|c|}{$\begin{array}{l}C V M_{1}=0,00 \\
C D F_{1}=13.737,00\end{array}$} & \multicolumn{2}{|c|}{$\begin{array}{l}C V M_{2}=0,00 \\
C D F_{2}=14.815,00\end{array}$} & \multicolumn{2}{|c|}{$\begin{array}{l}C V M_{3}=0,00 \\
C D F_{3}=13.725,00\end{array}$} \\
\hline
\end{tabular}

\begin{tabular}{|c|c|c|c|c|}
\hline \multicolumn{5}{|c|}{ UEN-5 - Faculdade de Ciências Humanas, Letras e Artes } \\
\hline Cursos & \multicolumn{2}{|c|}{ Curso 4: Pedagogia } & \multicolumn{2}{|c|}{ Curso 5: Mestrado } \\
\hline Períodos & $\begin{array}{c}Q_{4 j} \\
\text { (número de alunos) }\end{array}$ & $\begin{array}{c}C D F_{4 j} \\
\text { (médio por periodo) }\end{array}$ & $\begin{array}{c}Q_{5 j} \\
\text { (número de alunos) }\end{array}$ & $\begin{array}{c}C D F_{5 j} \\
\text { (médio por periodo) }\end{array}$ \\
\hline $1^{\circ}$ Ano & 97 & $13.896,00$ & 30 & 0,00 \\
\hline $2^{\circ}$ Ano & 78 & $14.723,00$ & 30 & 0,00 \\
\hline $3^{\circ}$ Ano & 72 & $13.915,00$ & -- & -- \\
\hline $4^{\circ}$ Ano & 45 & $7.789,00$ & -- & -- \\
\hline \multicolumn{3}{|c|}{$\begin{array}{l}P V_{4 j}=367,00 \\
D P F_{4 j}=27,16\end{array}$} & \multicolumn{2}{|l|}{$\begin{array}{l}P V_{5 j}=860,00 \\
D P F_{5 j}=63,64\end{array}$} \\
\hline \multicolumn{3}{|c|}{$\begin{array}{l}C V M_{4}=0,00 \\
C D F_{4}=15 \cdot 076,00\end{array}$} & \multicolumn{2}{|l|}{$\begin{array}{l}C V M_{5}=0,00 \\
C D F_{5}=124.825,00\end{array}$} \\
\hline
\end{tabular}

Tabela 6.6 - Custos e Despesas Fixas das UENs e da Sede Administrativa

\begin{tabular}{|c|}
\hline$C D F($ UEN1) $=182.172,00$ \\
\hline$C D F($ UEN2) $=88.280,00$ \\
\hline$C D F($ UEN3) $=47.725,00$ \\
\hline$C D F($ UEN4) $=129.864,00$ \\
\hline$C D F\left(\right.$ UEN $\left._{5}\right)=47.883,00$ \\
\hline$C D F($ SEDE $)=464.571,00$ \\
\hline
\end{tabular}


Em primeira análise, sem a identificação dos Indicadores de Posição Econômica, pode-se ver a UEN sob a ótica do Custeio Direto, analisando a composição e proporcionalidades dos Custos e Despesas Fixas, das Margens de Contribuição dos Produtos, tanto a unitária quanto a total.

Nesse sentido, a partir dos dados apresentados nas Tabelas-6.1 a 6.5, deve-se aplicar o Custeio Direto de forma a gerar a base de dados para o cálculo dos indicadores de posição econômica. Portanto, como resolução inicial, será utilizado a Representação Esquemática do Modelo Econômico da Empresa apresentada nas Figuras-6.2 a 6.7 .

Sob esta ótica, ao decidir sobre qual produto merece maior incentivo às vendas, a análise da margem de contribuição unitária oferece a condição necessária, segundo a ordem de classificação decrescente.

Como a empresa em questão é uma prestadora de serviço e a maioria dos produtos não possuem Custos Variáveis ou são proporcionalmente pequenos em comparação com o preço de venda, a Margem Bruta de Contribuição unitária será proporcional ao preço de venda.

Portanto, analisando os produtos da UEN-1 pode-se perceber que quanto mais Produto-1 e Produto-6 forem vendidos, maior será a margem de contribuição global obtida e mais facilmente serão cobertos todos os custos e despesa fixas da Unidade e, consequentemente, maior será o Resultado do período, pois esses produtos possuem o maior preço de venda dessa unidade e a maior margem bruta de contribuição unitária.

Essa mesma análise pode ser feita para todas as UENs apresentadas, pois o comportamento de todas são semelhantes. 
Figura 6.2 - Resultado da UEN-1 utilizando a Representação Esquemática do Modelo Econômico

\begin{tabular}{|c|c|}
\hline Produto 1 & \\
\hline \multicolumn{2}{|l|}{ Receita Líquida } \\
\hline$R L_{1.1}=(1.140,00-84,36) \times 60=$ & $63.338,40$ \\
\hline$R L_{12}=(1.140,00-84,36) \times 58=$ & $61.227,12$ \\
\hline$R L_{1,3}=(1.140,00-84,36)_{x} 53=$ & $55.948,92$ \\
\hline$R L_{1.4}=(1.140,00-84,36)_{x} 53=$ & $55.948,92$ \\
\hline$R L_{1.5}=(1.140,00-84,36) \times 48=$ & $50.670,72$ \\
\hline $\mathrm{RL}_{1}=$ & $287.134,08$ \\
\hline
\end{tabular}

\begin{tabular}{|c|c|}
\hline \multicolumn{2}{|l|}{ Produto 2} \\
\hline \multicolumn{2}{|l|}{ Receita Líquida } \\
\hline $\mathrm{RL}_{21}=(961,00-71,11) \times 99=$ & $88.099,11$ \\
\hline $\mathrm{RL}_{22}=(961,00-71,11) \times 89=$ & $79.200,21$ \\
\hline $\mathrm{RL}_{23}=(961,00-71,11) \times 86=$ & $76.530,54$ \\
\hline $\mathrm{RL}_{24}=(961,00-71,11)_{\times} 79=$ & $70.301,31$ \\
\hline $\mathrm{RL}_{2}=$ & $314.131,17$ \\
\hline
\end{tabular}

\begin{tabular}{rr|} 
Custos Variáveis & \\
$\mathrm{CV}_{21}=4,80 \times 99=$ & 475,20 \\
$\mathrm{CV}_{22}=4,80 \times 89=$ & 427,20 \\
$\mathrm{CV}_{23}=4,80 \times 86=$ & 412,80 \\
$\mathrm{CV}_{24}=4,80 \times 79=$ & 379,20 \\
$\mathrm{CV}_{2}=$ & $\mathbf{1 . 6 9 4 , 4 0}$ \\
\hline
\end{tabular}

Margem Bruta de Contribuição $\mathrm{MBC}_{21}=88.099,11-475,20=87.623,91$ $\mathrm{MBC}_{22}=79.200,21-427,20=78.773,01$ MBC $=76.530,54-412,80=76.117,74$ $\mathrm{MBC}_{24}=70.301,31-379,20=69.922,11$ $\mathrm{MBC}_{2}=312.436,77$

(-) Custos Fixos Próprios

$(-)$

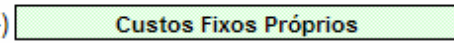

Margem Semi-Bruta de Contribuição MSBC $_{1.1}=62.729,40-30.234=32.495,40$ MSBC $_{12}=60.638,42-38.344=22.294 .42$

$=$ MSBC $_{13}=55.410,97-45.218=10.192,97$ MSBC $_{1.4}=55.410,97-55.889=(478,03)$ MSBC $_{15}=50.138,52-64.800=(14.616,48)$ $\mathrm{MSBC}_{1}=49.888,28$

Atividade Identificada com o Produto 1

$(=)$\begin{tabular}{|c|c|}
\hline $\begin{array}{c}\text { Custos de Despesas Fixas } \\
\text { Próprias }\end{array}$ & $\begin{array}{c}\text { Margem } \\
\text { Bruta de } \\
\text { Contribuição } \\
\text { Total do } \\
\text { S8.036 }\end{array}$ \\
$\begin{array}{c}\text { Mroduto } \\
\text { MSBC Total do Produto } \\
(8.148)\end{array}$ & 49.888 \\
\hline
\end{tabular}

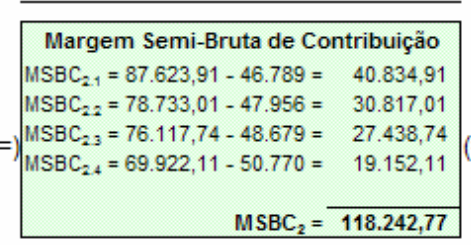

Atividade Identificada com o Produto 2
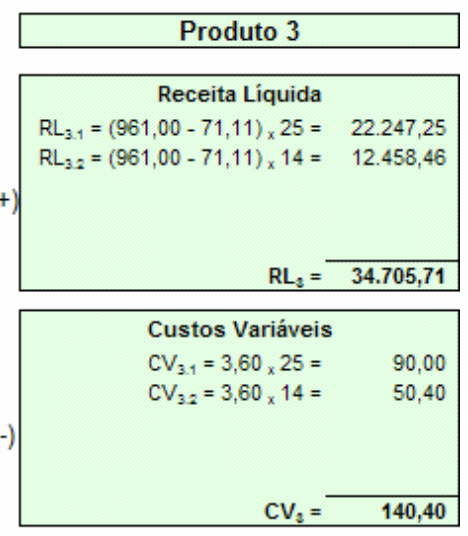

Margem Bruta de Contribuição $\mathrm{MBC}_{3.1}=22.247,25-90,00=22.157,25$ $\mathrm{MBC}_{32}=12.458,46-50,40=12.408,06$ $(=$

(-)

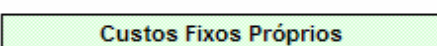

Margem Semi-Bruta de Contribuição MSBC $_{3.1}=22.157,25-26.957=(4.799,75)$ $\mathrm{MSBC}_{32}=12.404,06-36.481=(24.072,94)$ (=) (=

\section{.}

$\mathrm{MSBC}_{3}=(28.872,69)$

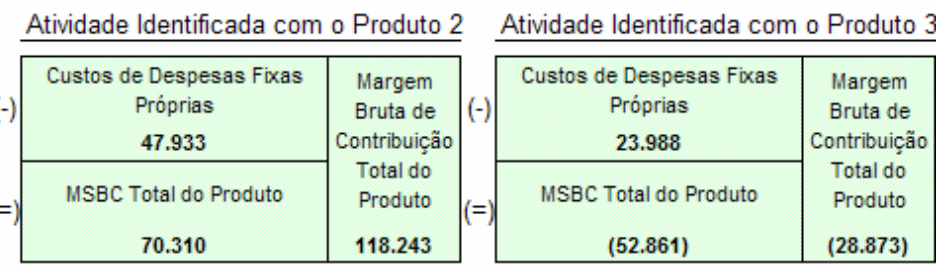

\section{Apuração do Resultado no Período - UEN 1}

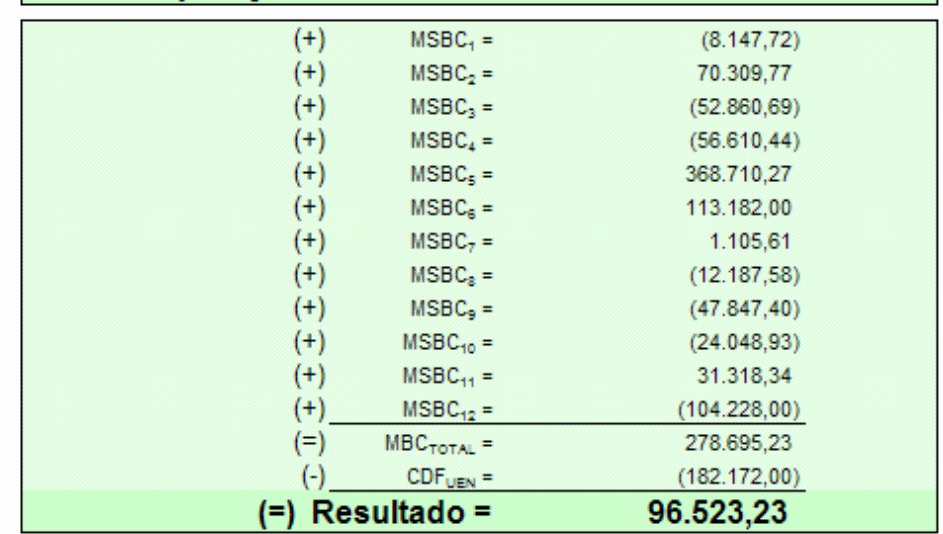


Figura 6.2 - Continuação

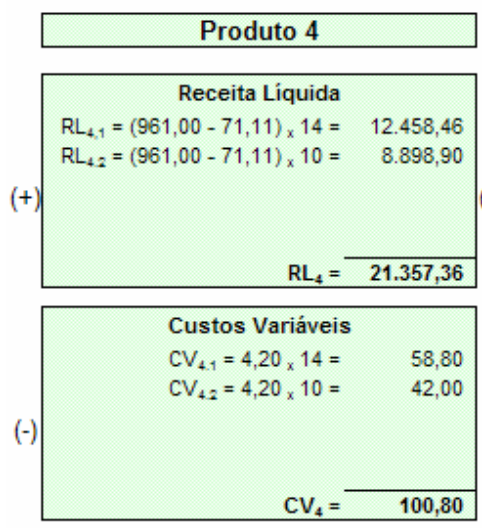

Margem Bruta de Contribuição $\mathrm{MBC}_{41}=12.458,46-58,80=12.399,66$ $\mathrm{MBC}_{42}=8.898,90-42,00=8.856,90$

(=)

$\mathrm{MBC}_{4}=21.256,56$

\section{$(-)$}

(-) ${ }^{\text {Custos Fixos Próprios }}$

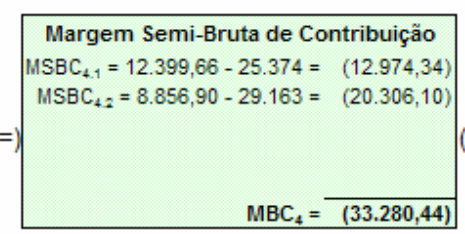

Atividade Identificada com o Produto 4

(=) \begin{tabular}{|c|c|}
\hline $\begin{array}{c}\text { Custos de Despesas Fixas } \\
\text { Próprias } \\
23.330\end{array}$ & $\begin{array}{c}\text { Margem } \\
\text { Bruta de } \\
\text { Contribuição } \\
\text { Total do } \\
\text { Produto } \\
\text { MSBC Total do Produto } \\
(56.610)\end{array}$ \\
$(33.280)$ \\
\hline
\end{tabular}

\section{Produto 5}

\section{Receita Líquida}

$R_{L_{1}}=(719,00-53,21) \times 199=132,492,21$

$\mathrm{RL}_{52}=(719,00-53,21) \times 198=131.826,42$

$\mathrm{RL}_{53}=(719,00-53,21) \times 194=129.163,26$ $\mathrm{RL}_{54}=(719,00-53,21) \times 195=129.829,05$

$R_{L_{5}}=(719,00-53,21) \times 197=131,160,63$ $\mathrm{RL}_{6}=654.471,57$

\begin{tabular}{rrr|} 
Custos Variáveis & \\
$\mathrm{CV}_{5.1}=2,10 \times 199=$ & 417,90 \\
$\mathrm{CV}_{5.2}=2,10 \times 198=$ & 415,80 \\
$\mathrm{CV}_{5,3}=2,10 \times 194=$ & 407,40 \\
$\mathrm{CV}_{5.4}=2,10 \times 195=$ & 409,50 \\
$\mathrm{CV}_{5.5}=2,10 \times 197=$ & 413,70 \\
\hline $\mathrm{CV}_{5}=$ & $2.064,30$ \\
\hline
\end{tabular}

Margem Bruta de Contribuição MBC $_{51}=132.492,21-417,90=132.074,31$ $\mathrm{MBC}_{52}=131.826,42-415,80=131.410,62$ $\mathrm{MBC}_{53}=129.163,26-407,40=128.755,86$ $\mathrm{MBC}_{5,4}=129.829,05-409,50=129.419,55$ $M B C_{55}=131.160,63-413,70=130,746,93$ $\mathrm{MBC}_{6}=652.407,27$
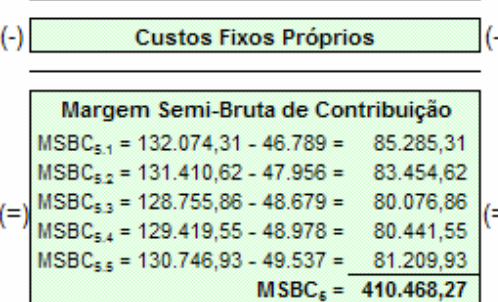
$\mathrm{MSBC}_{5}=410.468,27$

Atividade Identificada com o Produto 5

\begin{tabular}{|c|c|}
\hline $\begin{array}{c}\text { Custos de Despesas Fixas } \\
\text { Próprias }\end{array}$ & $\begin{array}{c}\text { Margem } \\
\text { Bruta de } \\
\text { Contribuição } \\
\text { Total do } \\
\text { Produto }\end{array}$ \\
\hline MSBC Total do Produto & 410.468 \\
\hline 368.710 & \\
\hline
\end{tabular}

\section{Produto 6}

\section{Receita Líquida}

$R_{S_{1}}=(1.144,00-84.66) \times 90=95.340,60$

$\mathrm{RL}_{\mathrm{B} 2}=(1.144,00-84,66) \times 83=87.925,22$

$\mathrm{RL}_{63}=(1.144,00-84,66)_{\times} 81=85.806,54$

$R_{5.4}=(1.144,00-84,66) \times 79=83.687,86$

$\mathrm{L}_{\mathrm{B}}=(1.144,00-84,66) \times 70=74.1$

$\mathrm{RL}_{8}=426.914,02$

\begin{tabular}{rr|}
\hline Custos Variáveis & \\
$\mathrm{CV}_{6,1}=11,34 \times 90=$ & $1.020,60$ \\
$\mathrm{CV}_{6.2}=11,34 \times 83=$ & 941,22 \\
$\mathrm{CV}_{6,3}=11,34 \times 81=$ & 918,54 \\
$\mathrm{CV}_{6.4}=11,34 \times 79=$ & 895,86 \\
$\mathrm{CV}_{65}=11,34 \times 70=$ & 793,80 \\
$\mathrm{CV}_{8}=$ & $\mathbf{4 . 5 7 0 , 0 2}$ \\
\hline
\end{tabular}

Margem Bruta de Contribuição $\mathrm{BBC}_{51}=95.340,60-1.020,60=94.320,00$ MBC $_{62}=87.925,22-941,22=86.984,00$ $\mathrm{MBC}_{63}=85.806,54-918,54=84.888,00$ $\mathrm{MBC}_{54}=83.687,86-895,86=82.792,00$ $M B C_{55}=74.153,80-793,80=73.360,00$ $\mathrm{MBC}_{8}=422.344,00$

\section{Custos Fixos Próprios}

\begin{tabular}{|c|c|}
\hline \multicolumn{2}{|c|}{ Margem Semi-Bruta de Contribuição } \\
\hline $\mathrm{MSBC}_{6.1}=94.320,00-38.546=$ & $55.774,00$ \\
\hline $\mathrm{MSBC}_{62}=$ & $46.028,00$ \\
\hline$M_{S B C}{ }_{63}=84.888,00-45.579=$ & $39.309,00$ \\
\hline $\operatorname{MSBC}_{6.4}=82.792,00-47.975=$ & $34.817,00$ \\
\hline $5=73.360,00-50.502=$ & $22.858,00$ \\
\hline
\end{tabular}

Atividade Identificada com o Produto 6

$\left(\begin{array}{c|c|}\hline \begin{array}{c}\text { Custos de Despesas Fixas } \\ \text { Próprias } \\ 85.604\end{array} & \begin{array}{c}\text { Margem } \\ \text { Bruta de } \\ \text { Contribuição } \\ \text { Total do } \\ \text { Produto } \\ \text { MSBC Total do Produto } \\ 113.182\end{array} \\ 198.786 \\ \hline\end{array}\right.$


Figura 6.2 - Continuação
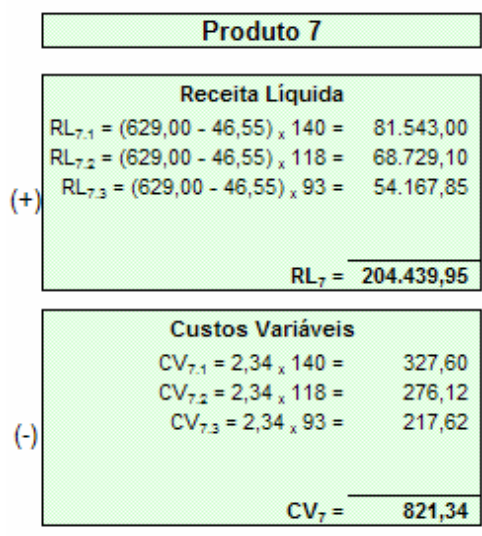

Margem Bruta de Contribuição MBC $_{7.1}=81.543,00-327,60=81.215,40$ $\mathrm{MBC}_{72}=68.729,10-276,12=68.452,98$ $(=$ $\mathrm{MBC}_{73}=54 \cdot 167,85-217,62=53 \cdot 950,23$

$\mathrm{MBC}_{7}=203.618,61$
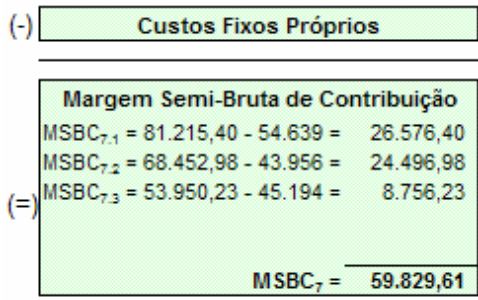

Atividade Identificada com o Produto 7

$(=)$\begin{tabular}{|c|c|}
\hline $\begin{array}{c}\text { Custos de Despesas Fixas } \\
\text { Próprias } \\
58.724\end{array}$ & $\begin{array}{c}\text { Margem } \\
\text { Bruta de } \\
\text { Contribuição } \\
\text { Total do } \\
\text { Produto } \\
\text { MSBC Total do Produto } \\
1.106\end{array}$ \\
\hline 59.830 \\
\hline
\end{tabular}

\begin{tabular}{|c|c|}
\hline \multicolumn{2}{|l|}{ Produto 8} \\
\hline \multicolumn{2}{|l|}{ Receita Líquida } \\
\hline $\mathrm{RL}_{8.1}=(963,00-71,26)_{\times} 46=$ & $41.020,04$ \\
\hline $\mathrm{RL}_{8.2}=(963,00-71,26) \times 38=$ & $33.886,12$ \\
\hline $\mathrm{RL}_{8,3}=(963,00-71,26) \times 23=$ & $20.510,02$ \\
\hline $\mathrm{RL}_{3.4}=(963,00-71,26) \times 19=$ & $16.943,06$ \\
\hline $\mathrm{RL}_{8}=$ & $112.359,24$ \\
\hline
\end{tabular}

\begin{tabular}{|rr|}
\hline Custos Variáveis & \\
$\mathrm{CV}_{3.1}=4,57 \times 46=$ & 210,22 \\
$\mathrm{CV}_{8.2}=4,57 \times 38=$ & 173,66 \\
$\mathrm{CV}_{83}=4,57 \times 23=$ & 105,11 \\
$\mathrm{CV}_{3.4}=4,57 \times 19=$ & 86,83 \\
$\mathrm{CV}_{8}=$ & $\mathbf{5 7 5 , 8 2}$ \\
\hline
\end{tabular}

Margem Bruta de Contribuição $\mathrm{MBC}_{3.1}=41.020,04-210,22=40.809,82$ $\mathrm{MBC}_{32}=33.886,12-173,66=33.712,46$ $\mathrm{MBC}_{33}=20.510,02-105,11=20.404,91$ $\mathrm{MBC}_{34}=16.943,06-86,83=16.856,23$ $\mathrm{MBC}_{8}=\overline{111.783,42}$

\section{$(-)$ Custos Fixos Próprios}

Margem Semi-Bruta de Contribuição MSBC $_{3.1}=40.809,82-19.325=21.484,82$ MSBC $_{32}=33.712,46-22.967=10.745,46$ $\mathrm{MSBC}_{33}=20.404,91-25.650=(5.245,09)$ $\mathrm{MSBC}_{3.4}=16.856,23-28.668=(11.811,77)$

$\mathrm{MSBC}_{8}=15.173,42$

Atividade Identificada com o Produto 8

\begin{tabular}{|c|c|}
\hline $\begin{array}{c}\text { Custos de Despesas Fixas } \\
\text { Próprias } \\
27.361\end{array}$ & $\begin{array}{c}\text { Margem } \\
\text { Bruta de } \\
\text { Contribuição } \\
\text { Total do } \\
\text { Produto } \\
\text { MSBC Total do Produto } \\
\text { (12.188) }\end{array}$ \\
(15.173 \\
\hline
\end{tabular}
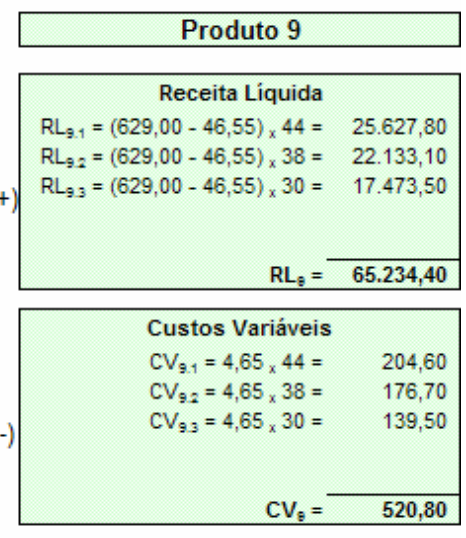

Margem Bruta de Contribuição $\mathrm{MBC}_{9.1}=25.627,80-204,60=25.423,20$ $M B C_{9.2}=22.133,10-176,70=21.956,40$

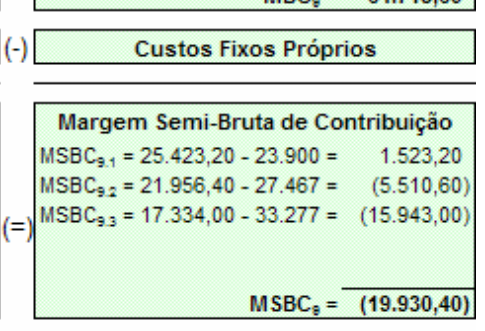

Atividade Identificada com o Produto 9

\begin{tabular}{|c|c|}
\hline $\begin{array}{c}\text { Custos de Despesas Fixas } \\
\text { Próprias }\end{array}$ & $\begin{array}{c}\text { Margem } \\
\text { Bruta de } \\
\text { Contribuição } \\
\text { Total do } \\
\text { Produto } \\
\text { MSBC Total do Produto }\end{array}$ \\
(47.847) & $(19.930)$ \\
\hline
\end{tabular}


Figura 6.2 - Continuação
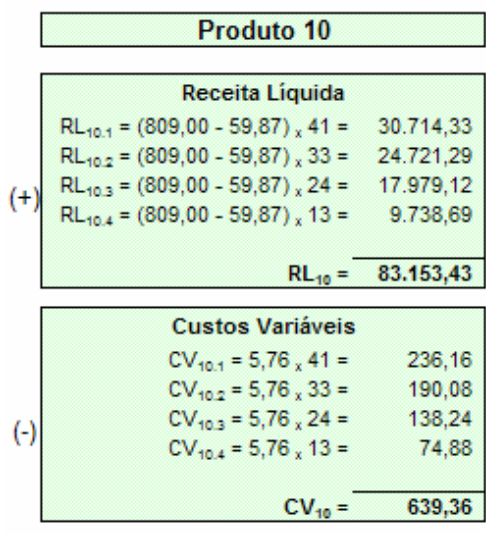

Margem Bruta de Contribuição MBC $_{10.1}=30.714,33-236,16=30.478,17$ MBC $_{102}=24.721,29-190,08=24.531,21$ $=\quad \mathrm{MBC}_{10.3}=17.979,12-138,24=17.840,88$ $\mathrm{MBC}_{104}=9.738,69-74,88=9.663,81$

$\mathrm{MBC}_{10}=82.514,07$
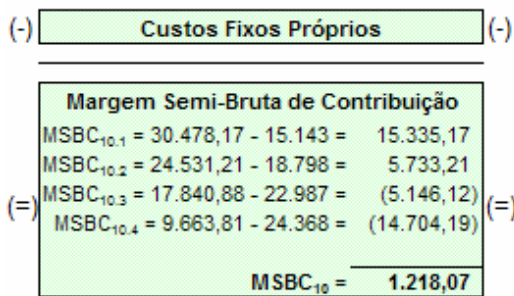

\begin{tabular}{|c|c|}
\hline \multicolumn{2}{|l|}{ Produto 11} \\
\hline \multicolumn{2}{|l|}{ Receita Líquida } \\
\hline $\mathrm{RL}_{11.1}=(629,00-46,55) \times 96=$ & $55.915,20$ \\
\hline $\mathrm{RL}_{112}=(629,00-46,55) \times 85=$ & $49.508,25$ \\
\hline $\mathrm{RL}_{11,3}=(629,00-46,55)_{\times} 79=$ & $46.013,55$ \\
\hline $\mathrm{RL}_{11,4}=(629,00-46,55) \times 62=$ & $36.111,90$ \\
\hline $\mathrm{RL}_{11}=$ & $187.548,90$ \\
\hline
\end{tabular}

\begin{tabular}{rrr|}
\hline Custos Variáveis & \\
$\mathrm{CV}_{11.1}=8,98 \times 96=$ & 862,08 \\
$\mathrm{CV}_{11.2}=8,98 \times 85=$ & 763,30 \\
$\mathrm{CV}_{11.3}=8,98 \times 79=$ & 709,42 \\
$\mathrm{CV}_{11.4}=8,98 \times 62=$ & 556,76 \\
& \\
$\mathrm{CV}_{11}=$ & $\mathbf{2 . 8 9 1 , 5 6}$ \\
\hline
\end{tabular}

Margem Bruta de Contribuição MBC $_{11.1}=55.915,20-862,08=55.053,12$ $M_{1 B C_{112}}=49.508,25-763,30=48.744,95$ $\mathrm{MBC}_{113}=46.013,55-709,42=45.304,13$ MBC $_{114}=36.111,90-556,76=35.555,14$

$\mathrm{MBC}_{11}=184.657,34$
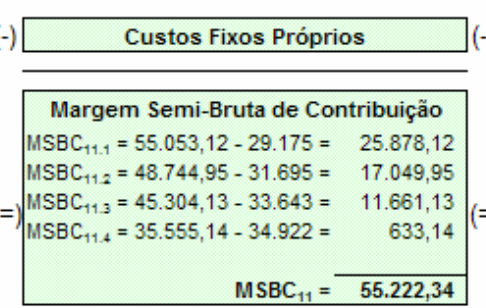

.

10

\begin{tabular}{|c|c|}
\hline $\begin{array}{c}\text { Atividade Identificada com o Produto } 10 \\
\text { Custos de Despesas Fixas } \\
\text { Próprias } \\
25.267\end{array}$ & $\begin{array}{c}\text { Margem } \\
\text { Bruta de } \\
\text { Contribuição } \\
\text { Total do } \\
\text { Produto } \\
\text { MSBC Total do Produto } \\
\text { (24.049) }\end{array}$ \\
\hline
\end{tabular}

Atividade Identificada com o Produto 11

\begin{tabular}{|c|c|}
\hline $\begin{array}{c}\text { Custos de Despesas Fixas } \\
\text { Próprias } \\
23.904\end{array}$ & $\begin{array}{c}\text { Margem } \\
\text { Bruta de } \\
\text { Contribuição } \\
\text { Total do } \\
\text { Produto } \\
\text { MSBC Total do Produto } \\
31.318\end{array}$ \\
55.222 \\
\hline
\end{tabular}

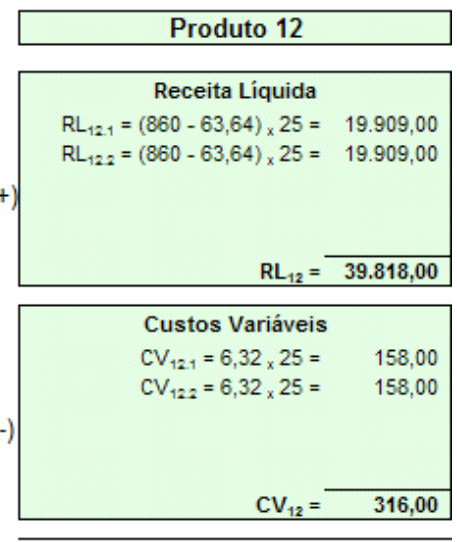

Margem Bruta de Contribuição $M_{B C_{121}}=19.909,00-158,00=19.751,00$ MBC $_{122}=19.909,00-158,00=19.751,00$ $=1$

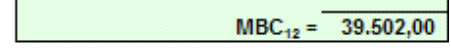

Custos Fixos Próprios

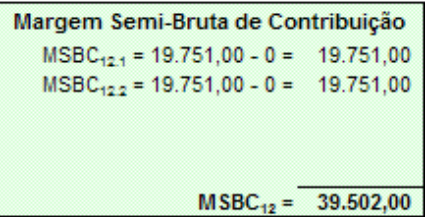

Atividade Identificada com o Produto 1

$(-)$\begin{tabular}{|c|c|}
\hline $\begin{array}{c}\text { Custos de Despesas Fixas } \\
\text { Próprias } \\
143.730\end{array}$ & $\begin{array}{c}\text { Margem } \\
\text { Bruta de } \\
\text { Contribuiçã } \\
\text { o Total do } \\
\text { Produto } \\
\text { MSBC Total do Produto } \\
\text { (104.228) }\end{array}$ \\
39.502 \\
\hline
\end{tabular}


Figura 6.3 - Resultado da UEN-2 utilizando a Representação Esquemática do Modelo Econômico

\begin{aligned} & \hline Produto 1 \\ &$(+) \quad$ Receita Líquida \\ & $\mathrm{RL}_{1.1}=(487,00-36,04) \times 428=193.010,88 \\ & \mathrm{RL}_{12}=(487,00-36,04) \times 346=156.032,16 \\ & \mathrm{RL}_{1.3}=(487,00-36,04) \times 335=151.071,60 \\ & \mathrm{RL}_{1.4}=(487,00-36,04) \times 275=124.014,00 \\ & \mathrm{RL}_{1}=624.128,64 \\ &$\hline\end{aligned}
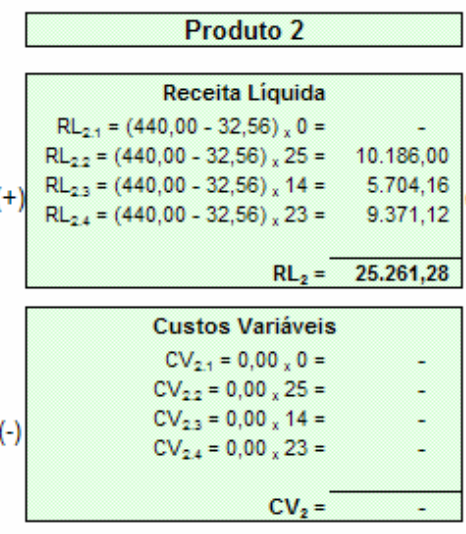

$C V_{1,1}=0,00 \times 428=$

$\mathrm{CV}_{12}=0,00 \times 346=$

(-) $\quad \mathrm{CV}_{1,3}=0,00 \times 235=$

$\mathrm{CV}_{1}=$

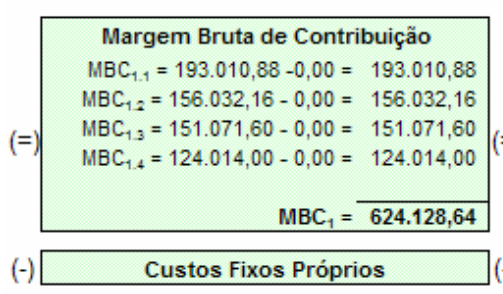

Margem Semi-Bruta de Contribuição MSBC $_{1.1}=193.010,88-88.500=104.510,88$ MSBC $_{12}=156.032,16-74.900=81.132,16$

MSBC $_{13}=151.071,60-68.100=82.971,60$

$=$ ) $\mathrm{MSBC}_{1.4}=124.014,00-63.600=60.414,00$

$\mathrm{MSBC}_{1}=329.028,64$

Atividade Identificada com o Produto 1

$(=)$\begin{tabular}{|c|c|}
\hline $\begin{array}{c}\text { Custos de Despesas Fixas } \\
\text { Próprias } \\
55.253\end{array}$ & $\begin{array}{c}\text { Margem } \\
\text { Bruta de } \\
\text { Contribuição } \\
\text { Total do } \\
\text { Produto } \\
\text { MSBC Total do Produto } \\
273.776\end{array}$ \\
329.029 \\
\hline
\end{tabular}

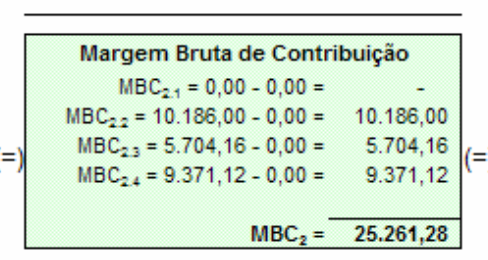

(-) $\quad$ Custos Fixos Próprios

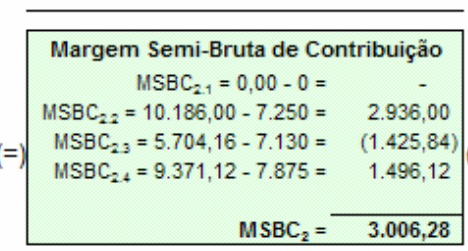

Atividade Identificada com o Produto 2

$(-)$\begin{tabular}{|c|c|}
\hline $\begin{array}{c}\text { Custos de Despesas Fixas } \\
\text { Próprias } \\
12.765\end{array}$ & $\begin{array}{c}\text { Margem } \\
\text { Bruta de } \\
\text { Contribuição } \\
\text { Total do } \\
\text { Produto } \\
\text { MSBC Total do Produto } \\
\text { (9.759) }\end{array}$ \\
\hline
\end{tabular}
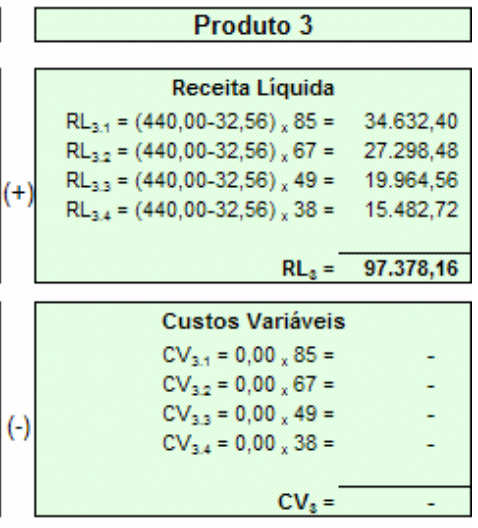

Margem Bruta de Contribuição $\mathrm{MBC}_{31}=34.632,40-0,00=34.632,40$ $\mathrm{MBC}_{32}=27.298,48-0,00=27.298,48$ $\mathrm{MBC}_{33}=19.964,56-0,00=19.964,56$ $\mathrm{MBC}_{34}=15.482,72-0,00=15.482,72$

$\mathrm{MBC}_{3}=97.378,16$

Custos Fixos Próprios

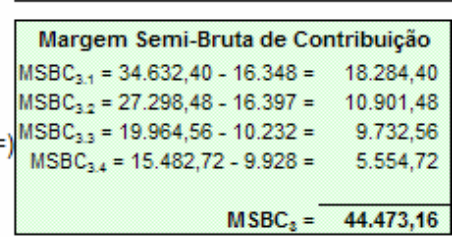

Atividade Identificada com o Produto 3

$\left(\begin{array}{c|c|}\hline \begin{array}{c}\text { Custos de Despesas Fixas } \\ \text { Próprias } \\ 18.254\end{array} & \begin{array}{c}\text { Margem } \\ \text { Bruta de } \\ \text { Contribuição } \\ \text { Total do } \\ \text { Produto }\end{array} \\ \hline \text { MSBC Total do Produto } & 44.473 \\ \hline 26.219 & \\ \hline\end{array}\right.$

\section{Apuração do Resultado no Periodo - UEN 2}

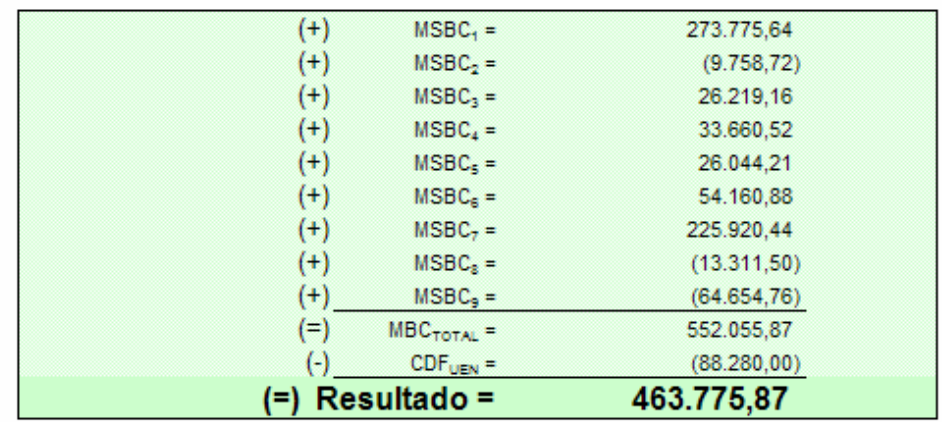


Figura 6.3 - Continuação
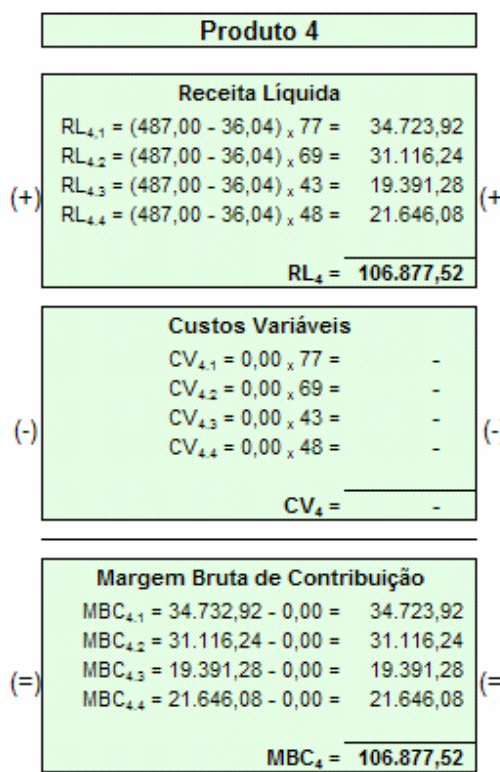

(-) Custos Fixos Próprios

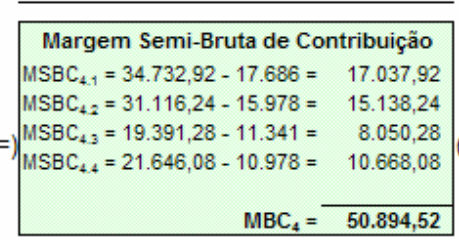

Atividade Identificada com o Produto 4

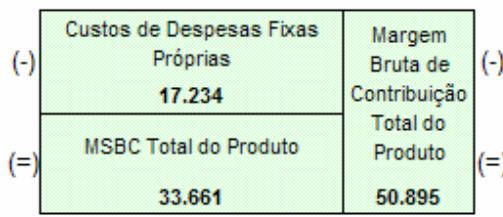
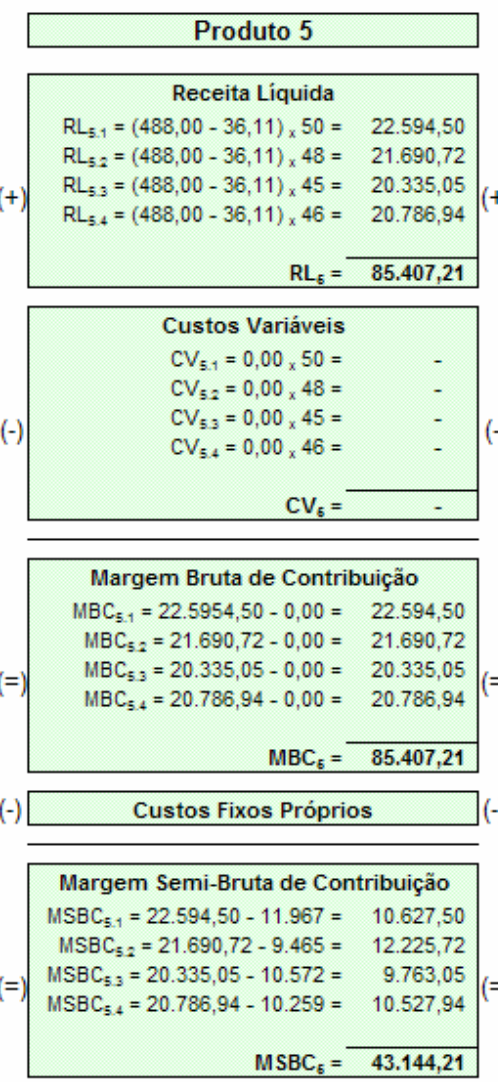

Atividade Identificada com o Produto 5

\begin{tabular}{|c|c|}
\hline $\begin{array}{c}\text { Custos de Despesas Fixas } \\
\text { Próprias } \\
17.100\end{array}$ & $\begin{array}{c}\text { Margem } \\
\text { Bruta de } \\
\text { Contribuição } \\
\text { Total do } \\
\text { Produto } \\
\text { MSBC Total do Produto } \\
26.044\end{array}$ \\
$\mathbf{4 3 . 1 4 4}$ \\
\hline
\end{tabular}

\section{Produto 6}

Receita Líquida

$\mathrm{RL}_{\mathrm{61}}=(493,00-36,48) \times 97=44.282,44$

$R L_{51}=(493,00-36,48) \times 86=39.260,72$

$\mathrm{RL}_{6.1}=(493,00-36,48) \times 69=31.499,88$

$\mathrm{RL}_{6.1}=(493,00-36,48) \times 67=30.586,84$

$\mathrm{RL}_{8}=145.629,88$

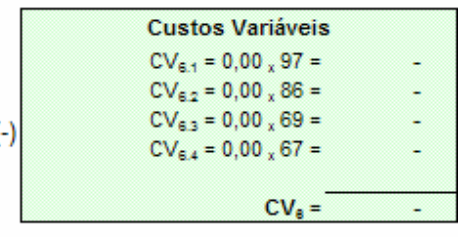

\section{Margem Bruta de Contribuição}

$\mathrm{MBC}_{\mathrm{s}_{1}}=44.282,44-0,00=44.282,44$

$M_{B B C_{62}}=39 \cdot 260,72-0,00=39 \cdot 260,72$

$\mathrm{MBC}_{63}=31.499,88-0,00=31.499,88$

$\mathrm{MBC}_{54}=30.586,84-0,00=30.586,84$

$\mathrm{MBC}_{6}=145.629,88$

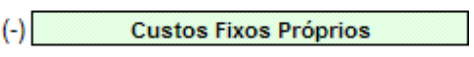

\section{Margem Semi-Bruta de Contribuição} MSBC $_{6.1}=44.282,44-18.153=26.129,44$ $\operatorname{MSBC}_{62}=39.260,72-17.879=21.381,72$ MSBC $_{83}=31.499,88-16.568=14.931,88$ ISBC $_{5}=30.586,84-16.634=13.952,84$ $\mathrm{MSBC}_{8}=76.395,88$

Atividade Identificada com o Produto 6

\begin{tabular}{|c|c|}
\hline $\begin{array}{c}\text { Custos de Despesas Fixas } \\
\text { Próprias }\end{array}$ & $\begin{array}{c}\text { Margem } \\
\text { Bruta de } \\
\text { Contribuição } \\
\text { Total do } \\
\text { Produto }\end{array}$ \\
\hline MSBC Total do Produto & 76.396 \\
\hline 54.161 & \\
\hline
\end{tabular}


Figura 6.3 - Continuação
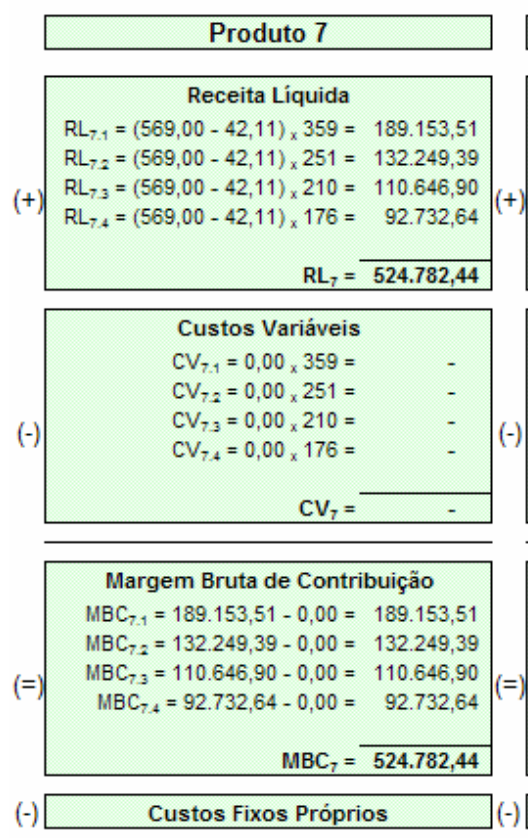

Margem Semi-Bruta de Contribuição MSBC $_{7.1}=189.153,51-74.890=114.263,51$ MSBC $_{72}=132.249,39-63.912=68.337,39$ $=$ MSBC $_{73}=110.646,90-54.891=55.755,90$ $=$ MSBC $_{73}=92.732,64-52.934=39.798,64$

$\mathrm{MSBC}_{7}=278.155,44$

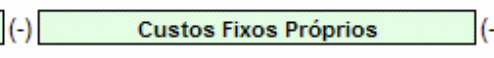

Atividade Identificada com o Produto 7

(=) \begin{tabular}{|c|c|}
\hline $\begin{array}{c}\text { Custos de Despesas Fixas } \\
\text { Próprias }\end{array}$ & $\begin{array}{c}\text { Margem } \\
\text { Bruta de } \\
\text { Contribuição } \\
52.235\end{array}$ \\
$\begin{array}{c}\text { Total do } \\
\text { Produto } \\
\text { MSBC Total do Produto } \\
225.920\end{array}$ \\
278.155 \\
\hline
\end{tabular}

\begin{tabular}{|c|c|}
\hline Produto 8 & \\
\hline \multicolumn{2}{|l|}{ Receita Líquida } \\
\hline $\mathrm{RL}_{8.1}=(350,00-25,90) \times 0=$ & - \\
\hline$R L_{8: 2}=(350,00-25,90)_{\times} 0=$ & - \\
\hline $\mathrm{RL}_{8,3}=(350,00-25,90) \times 28=$ & $9.074,80$ \\
\hline $\mathrm{RL}_{8.4}=(350,00-25,90)_{\times} 17=$ & $5.509,70$ \\
\hline $\mathrm{RL}_{8}=$ & $14.584,50$ \\
\hline
\end{tabular}

\begin{tabular}{rr|} 
Custos Variáveis & \\
$\mathrm{CV}_{3,1}=0,00 \times 0=$ & - \\
$\mathrm{CV}_{32}=0,00 \times 0=$ & - \\
$\mathrm{CV}_{3,3}=0,00 \times 28=$ & - \\
$\mathrm{CV}_{3,4}=0,00 \times 17=$ & - \\
$\mathrm{CV}_{8}=$ \\
\end{tabular}
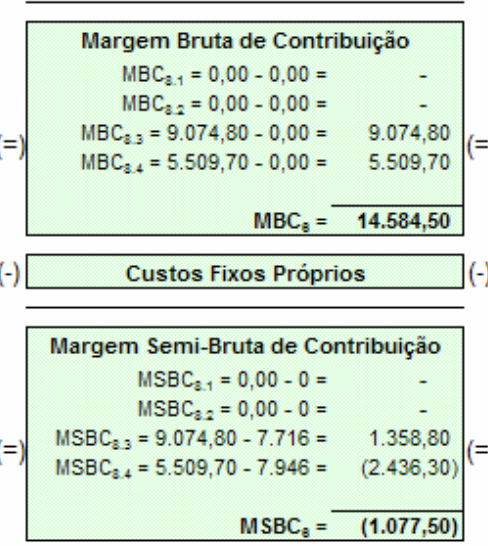

$\mathrm{MSBC}_{8}=(1.077,50)$
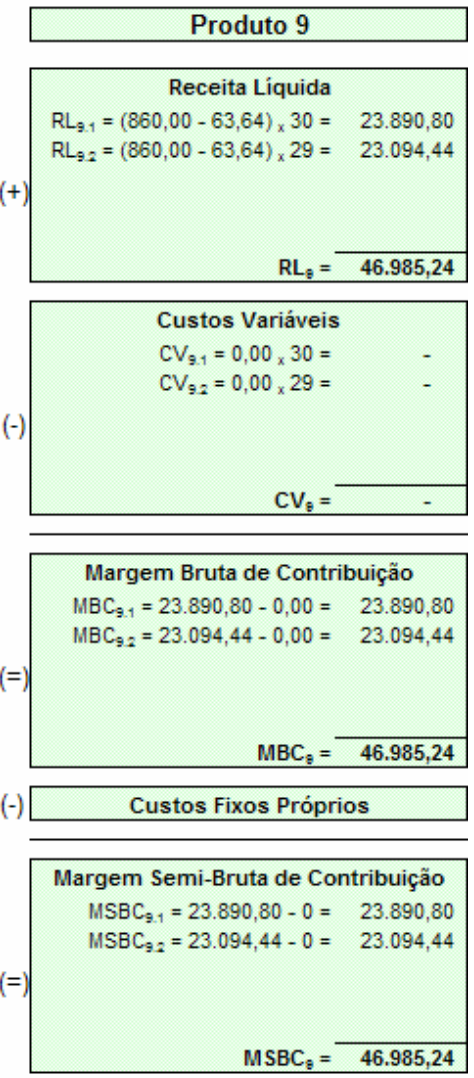

Atividade Identificada com o Produto 9

\begin{tabular}{|c|c|}
\hline $\begin{array}{c}\text { Custos de Despesas Fixas } \\
\text { Próprias } \\
12.234\end{array}$ & $\begin{array}{c}\text { Margem } \\
\text { Bruta de } \\
\text { Contribuição }\end{array}$ \\
\hline $\begin{array}{l}\text { MSBC Total do Produto } \\
\text { (13.312) }\end{array}$ & $\begin{array}{l}\text { Produto } \\
\text { (1.078) }\end{array}$ \\
\hline
\end{tabular}

$(-)$\begin{tabular}{|c|c|}
\hline $\begin{array}{c}\text { Custos de Despesas Fixas } \\
\text { Próprias } \\
111.640\end{array}$ & $\begin{array}{c}\text { Margem } \\
\text { Bruta de } \\
\text { Contribuição } \\
\text { Total do } \\
\text { Produto } \\
\text { MSBC Total do Produto } \\
\text { (64.655) }\end{array}$ \\
\hline
\end{tabular}


Figura 6.4 - Resultado da UEN-3 utilizando a Representação Esquemática do Modelo Econômico

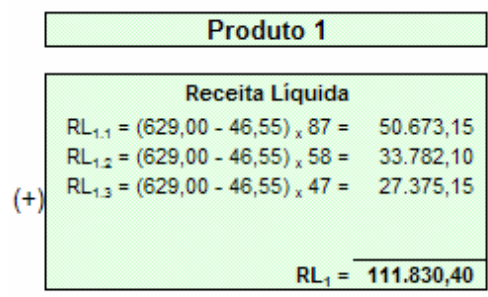

\begin{tabular}{|c|c|}
\hline \multicolumn{2}{|l|}{ Produto 2} \\
\hline \multicolumn{2}{|l|}{ Receita Líquida } \\
\hline$R L_{21}=(493,00-36,48) \times 48=$ & $21.912,96$ \\
\hline $\mathrm{RL}_{22}=(493,00-36,48)_{\times} 42=$ & $19.173,84$ \\
\hline $\mathrm{RL}_{23}=(493,00-36,48) \times 36=$ & $16.434,72$ \\
\hline $\mathrm{RL}_{2}=$ & $57.521,52$ \\
\hline
\end{tabular}
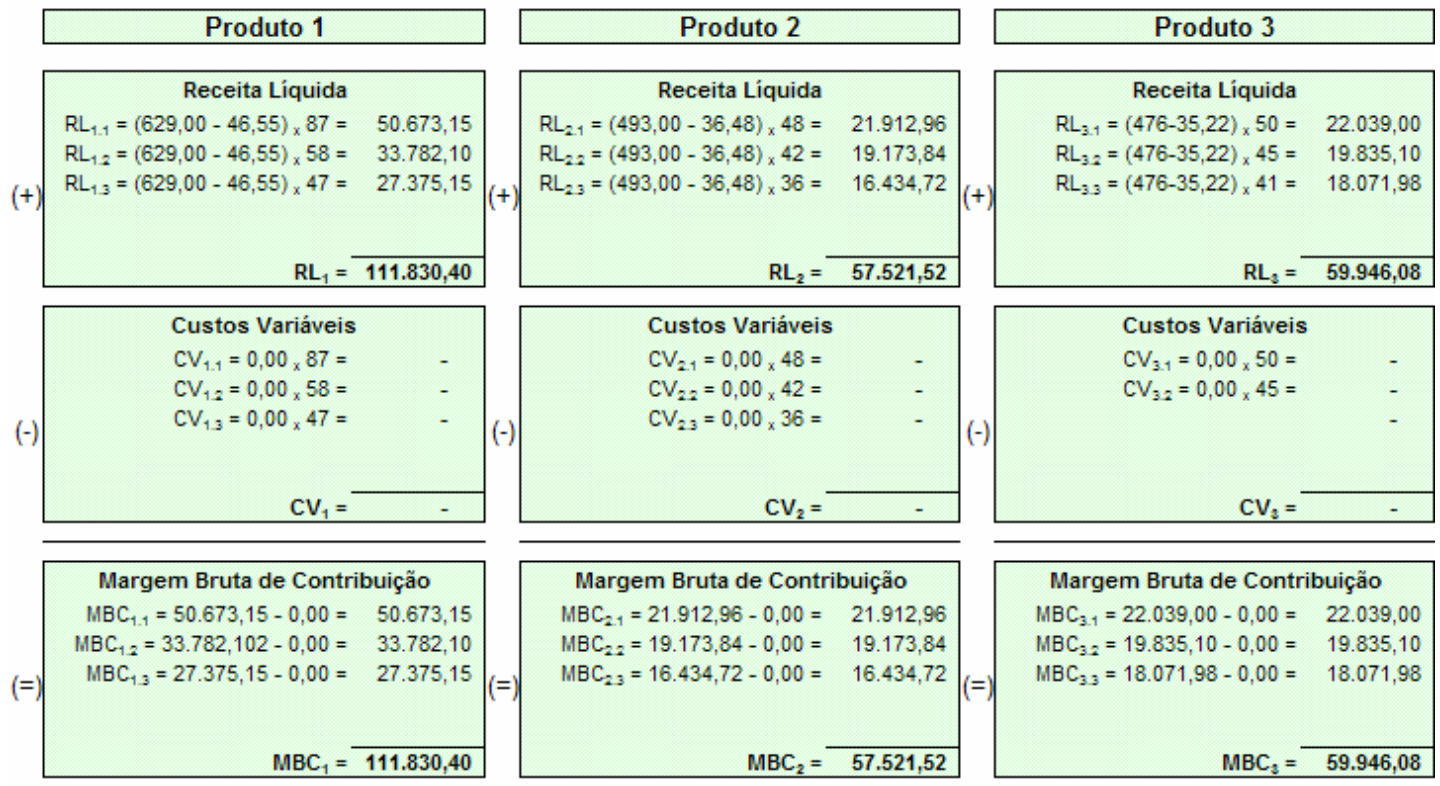

Margem Bruta de Contribuição $\mathrm{MBC}_{3.1}=22.039,00-0,00=22.039,00$ $\mathrm{MBC}_{32}=19.835,10-0,00=19.835,10$ $\mathrm{MBC}_{33}=18.071,98-0,00=18.071,98$

$(-)$ $\square(-)$

Custos Fixos Próprios
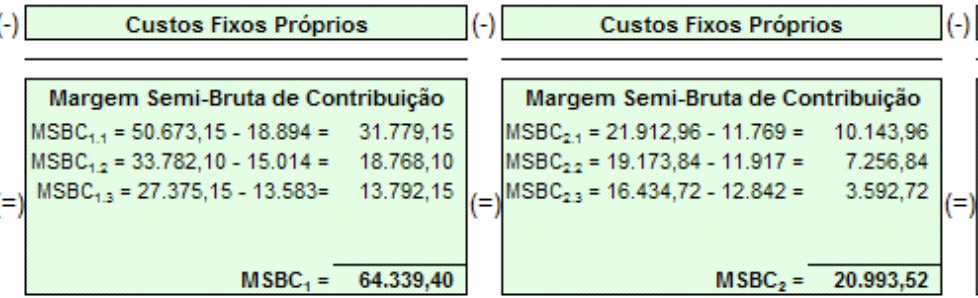

$\mathrm{MBC}_{3}=59.946,08$

Atividade Identificada com o Produto 1

Atividade Identificada com o Produto 2

$(=)$\begin{tabular}{|c|c|}
\hline $\begin{array}{c}\text { Custos de Despesas Fixas } \\
\text { Próprias }\end{array}$ & $\begin{array}{c}\text { Margem } \\
\text { Bruta de } \\
\text { Contribuição } \\
\text { Total do } \\
26.879\end{array}$ \\
\hline Produto \\
MSBC Total do Produto \\
37.460 & 64.339 \\
\hline
\end{tabular}

$(-)$\begin{tabular}{|c|c|}
$\begin{array}{c}\text { Custos de Despesas Fixas } \\
\text { Próprias } \\
15.769\end{array}$ & $\begin{array}{c}\text { Margem } \\
\text { Bruta de } \\
\text { Contribuição } \\
\text { Total do } \\
\text { Produto } \\
\text { MSBC Total do Produto } \\
5.225\end{array}$ \\
\hline
\end{tabular}

\begin{tabular}{|c|c|}
\hline $\begin{array}{c}\text { Custos de Despesas Fixas } \\
\text { Próprias } \\
22.654\end{array}$ & $\begin{array}{c}\text { Margem } \\
\text { Bruta de } \\
\text { Contribuição } \\
\text { Total do }\end{array}$ \\
\begin{tabular}{|c|c|} 
Produto \\
MSBC Total do Produto \\
7.101
\end{tabular} & 29.755 \\
\hline
\end{tabular}

\section{Apuração do Resultado no Período - UEN 3}

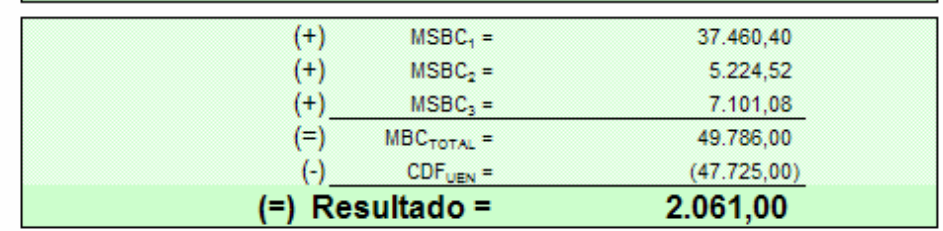


Figura 6.5 - Resultado da UEN-4 utilizando a Representação Esquemática do Modelo Econômico

\begin{tabular}{|c|c|}
\hline Produto 1 & \\
\hline \multicolumn{2}{|l|}{ Receita Líquida } \\
\hline$R L_{1.1}=(1.082,00-80,07) \times 46=$ & $46.088,78$ \\
\hline$R_{1.2}=(1.082,00-80,07) \times 35=$ & $35.067,55$ \\
\hline$R_{1,3}=(1.082,00-80,07) \times 28=$ & $28.054,04$ \\
\hline $\mathrm{RL}_{1.4}=(1.082,00-80,07) \times 19=$ & $19.036,67$ \\
\hline $\mathrm{RL}_{1,5}=(1.082,00-80,07) \times 8=$ & $8.015,44$ \\
\hline $\mathrm{RL}_{1}=$ & $136.262,48$ \\
\hline
\end{tabular}

\begin{tabular}{|c|c|}
\hline \multicolumn{2}{|l|}{ Produto 2} \\
\hline \multicolumn{2}{|l|}{ Receita Líquida } \\
\hline $\mathrm{RL}_{21}=(600,00-44,40) \times 50=$ & $27.780,00$ \\
\hline $\mathrm{RL}_{22}=(600,00-44,40) \times 47=$ & $26.113,20$ \\
\hline $\mathrm{RL}_{23}=(600,00-44,40) \times 38=$ & $21.112,80$ \\
\hline $\mathrm{RL}_{24}=(600,00-44,40) \times 17=$ & $9.445,20$ \\
\hline $\mathrm{RL}_{2}=$ & $84.451,20$ \\
\hline
\end{tabular}

\begin{tabular}{|c|c|}
\hline \multicolumn{2}{|l|}{ Produto 3} \\
\hline \multicolumn{2}{|l|}{ Receita Líquida } \\
\hline$R L_{31}=(520,00-38,38) \times 168=$ & $80.912,16$ \\
\hline$R L_{32}=(520,00-38,38) \times 139=$ & $66.945,18$ \\
\hline $\mathrm{RL}_{3,3}=(520,00-38,38) \times 144=$ & $69.353,28$ \\
\hline $\mathrm{RL}_{3,4}=(520,00-38,38) \times 108=$ & $52.014,96$ \\
\hline $\mathrm{RL}_{3}=$ & $269.225,58$ \\
\hline
\end{tabular}

\begin{tabular}{|c|c|c|}
\hline \multirow{7}{*}{$(-)$} & Custos Variáveis & \\
\hline & $C V_{1.1}=0,00 \times 46=$ & - \\
\hline & $\mathrm{CV}_{12}=0,00 \times 35=$ & - \\
\hline & $\mathrm{CV}_{13}=0,00 \times 28=$ & - \\
\hline & $\mathrm{CV}_{1,4}=0,00 \times 19=$ & - \\
\hline & $C V_{1.5}=0,00 \times 8=$ & - \\
\hline & $\mathrm{CV}_{1}=$ & - \\
\hline
\end{tabular}
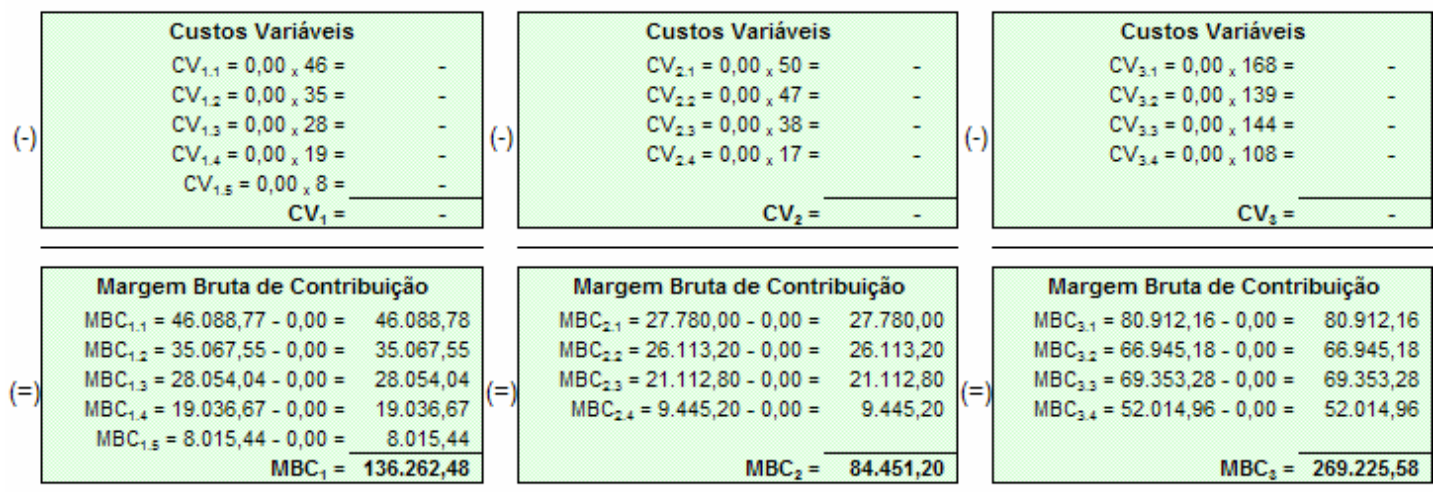

Margem Bruta de Contribuição $\mathrm{MBC}_{3.1}=80.912,16-0,00=80.912,16$ $\mathrm{MBC}_{32}=66.945,18-0,00=66.945,18$ $\mathrm{MBC}_{33}=69.353,28-0,00=69.353,28$ $\mathrm{MBC}_{3.4}=52.014,96-0,00=52.014,96$
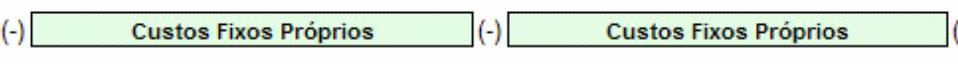

$\mathrm{MBC}_{3}=269.225,58$

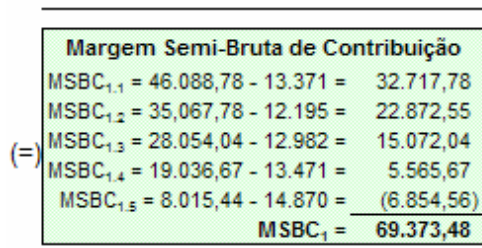

$=$

\begin{tabular}{rlc|} 
Margem Semi-Bruta de Contribuição \\
MSBC $_{21}=27.780,00-9.782=$ & $17.998,00$ \\
MSBC $_{22}=26.113,20-9.851=$ & $16.262,20$ \\
MSBC $_{23}=21.112,80-10.908=$ & $10.204,80$ \\
MSBC $_{24}=9.445,20-10.502=$ & $(1.056,80)$ \\
MSBC $_{2}=$ & $\mathbf{4 3 . 4 0 8 , 2 0}$
\end{tabular}

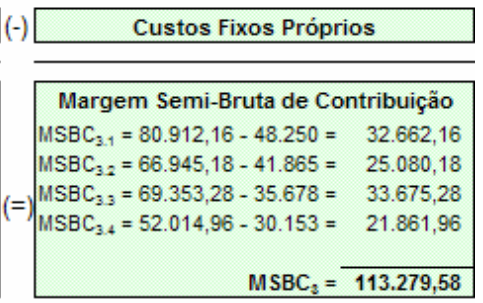

Atividade Identificada com o Produto 1

Atividade Identificada com o Produto 2

$(=)$\begin{tabular}{|c|c|}
\hline $\begin{array}{c}\text { Custos de Despesas Fixas } \\
\text { Próprias }\end{array}$ & $\begin{array}{c}\text { Margem } \\
\text { Bruta de } \\
\text { Contribuição } \\
\text { Total do } \\
\text { Produto } \\
\text { MSBC Total do Produto }\end{array}$ \\
43.920 & 69.373 \\
\hline
\end{tabular}

$(-)$\begin{tabular}{|c|c|}
\hline $\begin{array}{c}\text { Custos de Despesas Fixas } \\
\text { Próprias }\end{array}$ & $\begin{array}{c}\text { Margem } \\
\text { Bruta de } \\
\text { Contribuição } \\
\text { Total do } \\
\text { Produto } \\
\text { MSBC Total do Produto } \\
24.922\end{array}$ \\
43.408 \\
\hline
\end{tabular}

\begin{tabular}{|c|c|}
\hline $\begin{array}{c}\text { Atividade Identificada com o Produto } 3 \\
\text { (-) }\end{array}$ Próprias & $\begin{array}{c}\text { Margem } \\
\text { Bruta de } \\
\text { Contribuição } \\
\text { Total do } \\
\text { MS.564 }\end{array}$ \\
MSBC Total do Produto & Produto \\
70.716 & 113.280 \\
\hline
\end{tabular}

\begin{tabular}{|rrr|}
\hline \multicolumn{4}{|c|}{ Apuração do Resultado no Periodo - UEN 4 } \\
\hline$(+)$ & $\mathrm{MSBC}_{1}=$ & $43.920,48$ \\
$(+)$ & $\mathrm{MSBC}_{2}=$ & $24.922,20$ \\
$(+)$ & $\mathrm{MSBC}_{3}=$ & $70.715,58$ \\
$(+)$ & $\mathrm{MSBC}_{4}=$ & $20.379,04$ \\
$(+)$ & $\mathrm{MSBC}_{5}=$ & $38.908,43$ \\
$(+)$ & $\mathrm{MSBC}_{8}=$ & $4.794,44$ \\
$(+)$ & $\mathrm{MSBC}_{7}=$ & $(21.022,40)$ \\
$(+)$ & $\mathrm{MSBC}_{2}=$ & $(228,44)$ \\
$(+)$ & $\mathrm{MSBC}_{3}=$ & $10.955,60$ \\
$(=)$ & $\mathrm{MBC}_{\text {OOTA }}=$ & $193.344,93$ \\
$(-)$ & $\mathrm{CDF}_{\text {UEN }}=$ & $(129.864,00)$ \\
(=) Resultado $=$ & $\mathbf{6 3 . 4 8 0 , 9 3}$ \\
\hline
\end{tabular}


Figura 6.5 - Continuação
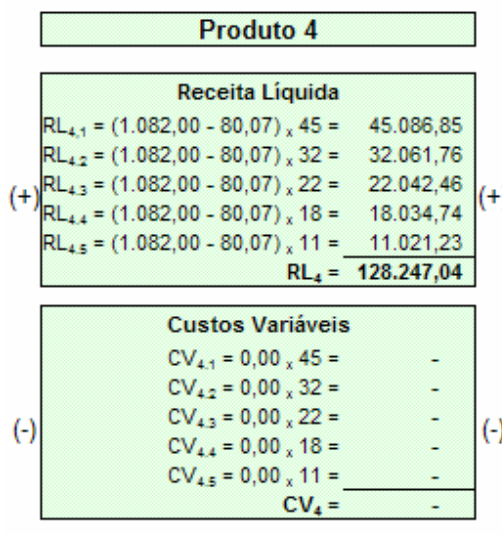
$\mathrm{CV}_{4}=$

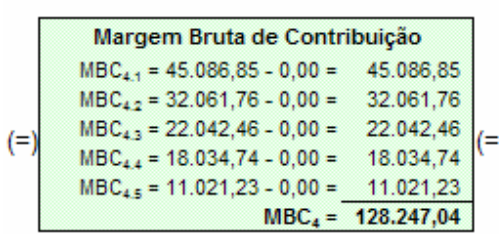

(-) Custos Fixos Próprios Margem Semi-Bruta de Contribuição MSBC $_{4.1}=45.086,85-12.162=32.924,85$ MSBC $_{42}=32.061,76-17.906=14.155,76$ MSBC $_{43}=22.042,46-17.862=4.180,46$

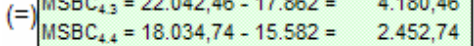
MSBC $_{42}=11.021,23-16.006=\frac{(4.984,77)}{48.729,04}$ $\mathrm{MBC}_{4}=48.729,04$

\begin{tabular}{|c|c|}
\hline Produto 5 & \\
\hline \multicolumn{2}{|l|}{ Receita Líquida } \\
\hline $\mathrm{RL}_{5.1}=(1.082,00-80,07) \times 50=$ & $50.096,50$ \\
\hline $\mathrm{RL}_{52}=(1.082,00-80,07) \times 38=$ & $38.073,34$ \\
\hline $\mathrm{RL}_{5,3}=(1.082,00-80,07) \times 25=$ & $25.048,25$ \\
\hline $\mathrm{RL}_{5.4}=(1.082,00-80,07) \times 23=$ & $23.044,39$ \\
\hline$R_{5.5}=(1.082,00-80,07) \times 15=$ & $15.028,95$ \\
\hline $\mathrm{RL}_{6}=$ & $151.291,43$ \\
\hline
\end{tabular}

$(-) \quad$\begin{tabular}{rr|} 
Custos Variáveis \\
$\mathrm{CV}_{5,1}=0,00 \times 50=$ & - \\
$\mathrm{CV}_{5,2}=0,00 \times 38=$ & - \\
$\mathrm{CV}_{5,3}=0,00 \times 25=$ & - \\
$\mathrm{CV}_{5,4}=0,00 \times 23=$ & - \\
$\mathrm{CV}_{5,5}=0,00 \times 15=$ & - \\
$\mathrm{CV}_{5}=$ & - \\
\hline
\end{tabular}
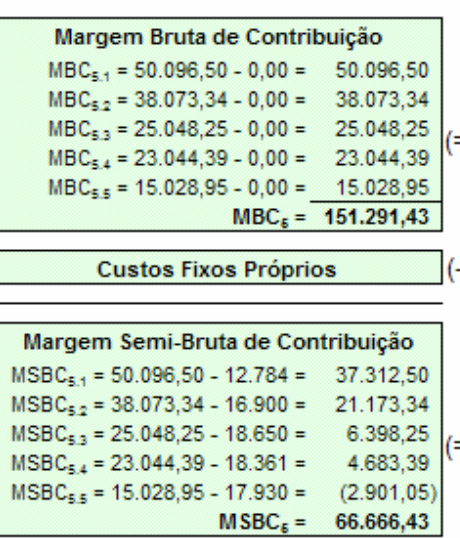

$\mathrm{MSBC}_{5}=66.666,43$

Atividade Identificada com o Produto 4

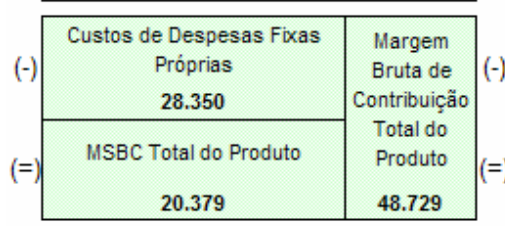

Atividade Identificada com o Produto 5

\begin{tabular}{|c|c|}
\hline $\begin{array}{c}\text { Custos de Despesas Fixas } \\
\text { Próprias }\end{array}$ & $\begin{array}{c}\text { Margem } \\
\text { Bruta de } \\
\text { Contribuição } \\
\text { Total do } \\
\text { Produto } \\
\text { MSBC Total do Produto }\end{array}$ \\
38.908 & 66.666 \\
\hline
\end{tabular}

\section{Produto 6}

\section{Receita Líquida}

$R_{51}=(1.082,00-80,07) \times 38=38.073,34$

$R L_{62}=(1.082,00-80,07) \times 25=25.048,25$

$\mathrm{RL}_{6.3}=(1.082,00-80,07) \times 20=20.038,60$ $R_{6.4}=(1.082,00-80,07) \times 18=18.034,74$

$R L_{0}=(1.082,00-80,07) \times 7=7.013,51$ $\mathrm{RL}_{8}=108.208,44$

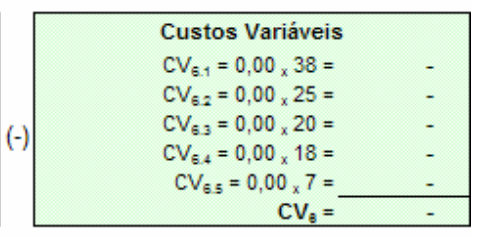

Margem Bruta de Contribuição $\mathrm{MBC}_{81}=38.073,34-0,00=38.073,34$ $\mathrm{MBC}_{82}=25.048,25-0,00=25.048,25$ $\mathrm{MBC}_{63}=20.038,60-0,00=20.038,60$ $M_{B C C_{44}}=18.038,74-0,00=18.034,74$ $\mathrm{MBC}_{65}=7.013,51-0,00=7.013,51$ $\mathrm{MBC}_{8}=108.208,44$

Custos Fixos Próprios

\begin{tabular}{|c|c|}
\hline \multicolumn{2}{|c|}{ Margem Semi-Bruta de Contribuição } \\
\hline ביב & $26.127,3$ \\
\hline & \\
\hline MSB & 60 \\
\hline MSBC & 74 \\
\hline $\mathrm{MSBC}_{6.5}=7.013,51-17$ & \\
\hline $\mathrm{MSBC}_{8}$ & 9.2 \\
\hline
\end{tabular}

Atividade Identificada com o Produto 6

$(-)$\begin{tabular}{|c|c|}
$\begin{array}{c}\text { Custos de Despesas Fixas } \\
\text { Próprias } \\
24.406\end{array}$ & $\begin{array}{c}\text { Margem } \\
\text { Bruta de } \\
\text { Contribuição } \\
\text { Total do } \\
\text { Produto } \\
\text { MSBC Total do Produto } \\
4.794\end{array}$ \\
29.200 \\
\hline
\end{tabular}


Figura 6.5 - Continuação
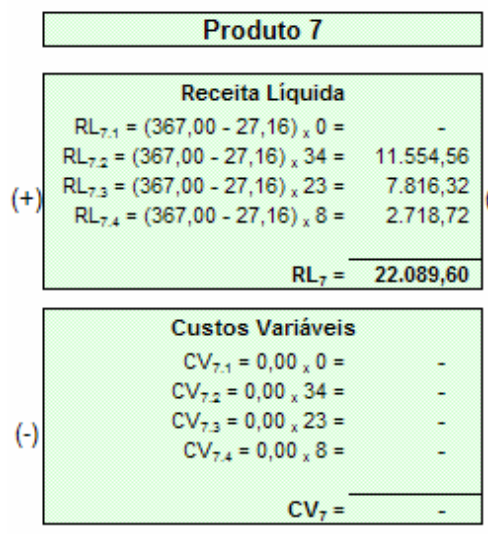

$\mathrm{CV}_{7}=$

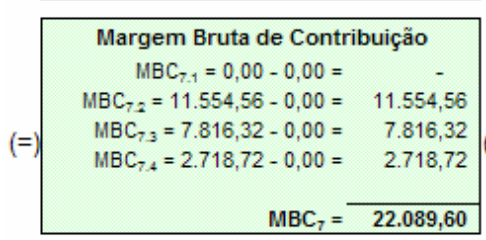

(-) Custos Fixos Próprios

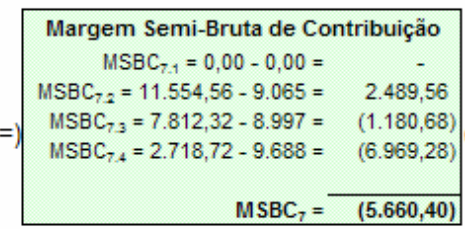

Atividade Identificada com o Produto

$(=)$\begin{tabular}{|c|c|}
\hline $\begin{array}{c}\text { Custos de Despesas Fixas } \\
\text { Próprias } \\
15.362\end{array}$ & $\begin{array}{c}\text { Margem } \\
\text { Bruta de } \\
\text { Contribuição } \\
\text { Total do } \\
\text { Produto } \\
\text { MSBC Total do Produto } \\
(21.022)\end{array}$ \\
\hline
\end{tabular}
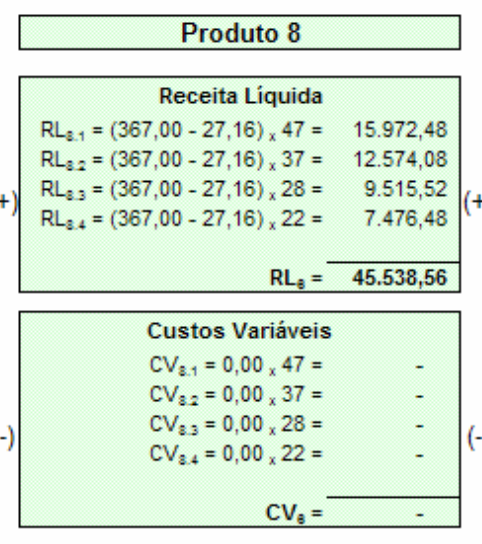

Margem Bruta de Contribuição $\mathrm{MBC}_{3.1}=15.972,48-0,00=15.972,48$ $\mathrm{MBC}_{32}=12.274,08-0,00=12.574,08$ $\mathrm{MBC}_{33}=9.515,52-0,00=9.515,52$ $\mathrm{MBC}_{34}=7.476,48-0,00=7.476,48$ $\mathrm{MBC}_{8}=45.538,56$

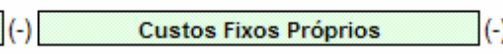

\begin{tabular}{rr|} 
Margem Semi-Bruta de Contribuição \\
$\mathrm{MSBC}_{3.1}=15.972,48-7.542=$ & $8.430,48$ \\
$\mathrm{MSBC}_{3.2}=12.574,08-8.190=$ & $4.384,08$ \\
$\mathrm{MSBC}_{3.3}=9.515,52-8.537=$ & 978,52 \\
$\mathrm{MSBC}_{3.4}=7.476,48-8.780=$ & $(1.303,52)$ \\
$\mathrm{MSBC}_{8}=$ & $\mathbf{1 2 . 4 8 9 , 5 6}$
\end{tabular}
$\checkmark(-)$ Custos Fixos Próprios

\begin{tabular}{rr|} 
Margem Semi-Bruta de Contribuição \\
$\operatorname{MSBC}_{9.1}=25.557,60-9.689=$ & $15.868,60$ \\
$\operatorname{MSBC}_{9.2}=18.334,80-9.241=$ & $9.093,80$ \\
$\operatorname{MSBC}_{9,3}=10.556,40-9.628=$ & 928,40 \\
$\operatorname{MSBC}_{9,3}=7.222,80-10.241=$ & $(3.018,20)$ \\
MSBC $_{8}=$ & $22.872,60$
\end{tabular}

Atividade Identificada com o Produto 8

Atividade Identificada com o Produto 9

\begin{tabular}{|c|c|c|c|c|}
\hline $\begin{array}{l}\text { Custos de Despesas Fixas } \\
\text { Próprias }\end{array}$ & $\begin{array}{l}\text { Margem } \\
\text { Bruta de } \\
\text { Contribuicã }\end{array}$ & $(-)$ & $\begin{array}{l}\text { Custos de Despesas Fixas } \\
\text { Próprias }\end{array}$ & $\begin{array}{l}\text { Margem } \\
\text { Bruta de }\end{array}$ \\
\hline MSBC Total do Produto & $\begin{array}{l}\text { Total do } \\
\text { Produto }\end{array}$ & & MSBC Total do Produto & $\begin{array}{l}\text { Total do } \\
\text { Produto }\end{array}$ \\
\hline (228) & 12.490 & & 10.956 & 22.873 \\
\hline
\end{tabular}


Figura 6.6 - Resultado da UEN-5 utilizando a Representação Esquemática do Modelo Econômico

\begin{tabular}{|c|c|}
\hline \multicolumn{2}{|l|}{ Produto 1} \\
\hline \multicolumn{2}{|l|}{ Receita Líquida } \\
\hline $\mathrm{RL}_{1.1}=(367,00-27,16) \times 87=$ & $29.566,08$ \\
\hline $\mathrm{RL}_{12}=(367,00-27,16) \times 68=$ & $23.109,12$ \\
\hline $\mathrm{RL}_{13}=(367,00-27,16)_{\times} 45=$ & $15.292,80$ \\
\hline $\mathrm{RL}_{1.4}=(367,00-27,16) \times 33=$ & $11.214,72$ \\
\hline $\mathrm{RL}_{1}=$ & $79.182,72$ \\
\hline
\end{tabular}

\begin{tabular}{|c|c|}
\hline \multicolumn{2}{|l|}{ Produto 2} \\
\hline \multicolumn{2}{|l|}{ Receita Líquida } \\
\hline $\mathrm{RL}_{21}=(367,00-27,16) \times 92=$ & $31.265,28$ \\
\hline $\mathrm{RL}_{22}=(367,00-27,16) \times 75=$ & $25.488,00$ \\
\hline $\mathrm{RL}_{23}=(367,00-27,16) \times 33=$ & $11.214,72$ \\
\hline$R L_{24}=(367,00-27,16) \times 35=$ & $11.894,40$ \\
\hline $\mathrm{RL}_{2}=$ & $79.862,40$ \\
\hline
\end{tabular}

\begin{tabular}{|c|c|}
\hline \multicolumn{2}{|l|}{ Produto 3} \\
\hline \multicolumn{2}{|l|}{ Receita Líquida } \\
\hline $\mathrm{RL}_{3.1}=(367,00-27,16) \times 89=$ & $30.245,76$ \\
\hline $\mathrm{RL}_{32}=(367,00-27,16) \times 71=$ & $24.128,64$ \\
\hline $\mathrm{RL}_{3,3}=(367,00-27,16)_{\times} 47=$ & $15.972,48$ \\
\hline$R L_{3.4}=(367,00-27,16) \times 25=$ & $8.496,00$ \\
\hline $\mathrm{RL}_{3}=$ & $78.842,88$ \\
\hline
\end{tabular}

$(-) \quad$\begin{tabular}{rr|} 
Custos Variáveis \\
$\mathrm{CV}_{1.1}=0,00 \times 87=$ & - \\
$\mathrm{CV}_{1,2}=0,00 \times 68=$ & - \\
$\mathrm{CV}_{1,3}=0,00 \times 45=$ & - \\
$\mathrm{CV}_{1,4}=0,00 \times 33=$ & - \\
$\mathrm{CV}_{1}=$ & - \\
\hline
\end{tabular}

Margem Bruta de Contribuição $M_{B C_{1.1}}=29.566,08-0,00=29.566,08$ $\mathrm{MBC}_{12}=23.109,12-0,00=23.109,12$ $\mathrm{MBC}_{13}=15.292,80-0,00=15.292,80$ $\mathrm{MBC}_{1.4}=11.214,72-0,00=11.214,72$

$\mathrm{MBC}_{1}=79.182,72$

Margem Bruta de Contribuição $\mathrm{MBC}_{21}=31.265,28-0,00=31.265,28$ $\mathrm{MBC}_{22}=25.488,00-0,00=25.488,00$ $\mathrm{MBC}_{23}=11.214,72-0,00=11.214,72$ $\mathrm{MBC}_{24}=11.894,40-0,00=11.894,40$ $\mathrm{MBC}_{2}=79.862,40$

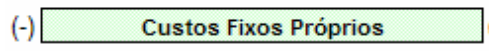
\begin{tabular}{|cr|}
\hline Margem Semi-Bruta de Contribuição \\
MSBC $_{1.1}=29.566,08-15.019=$ & $14.547,08$ \\
MSBC $_{1.2}=23.109,12-16.273=$ & $6.836,12$ \\
$\operatorname{MSBC}_{1,3}=15.292,80-8.902=$ & $6.390,80$ \\
$\operatorname{MSBC}_{1.4}=11.214,72-8.427=$ & $2.787,72$ \\
& \\
MSBC $_{1}=$ & $\mathbf{3 0 . 5 6 1 , 7 2}$ \\
\end{tabular}

Atividade Identificada com o Produto 1

$(=)$\begin{tabular}{|c|c|}
\hline $\begin{array}{c}\text { Custos de Despesas Fixas } \\
\text { Próprias } \\
13.737\end{array}$ & $\begin{array}{c}\text { Margem } \\
\text { Bruta de } \\
\text { Contribuição } \\
\text { Total do } \\
\text { Produto } \\
\text { MSBC Total do Produto } \\
16.825\end{array}$ \\
\hline
\end{tabular}

\begin{tabular}{|c|c|}
\hline Margem Semi-Bruta de Co & tribuição \\
\hline $\mathrm{MSBC}_{21}=31.265,28-14.376=$ & $16.889,28$ \\
\hline $\mathrm{MSBC}_{22}=25.488,00-14.580=$ & $10.908,00$ \\
\hline $\mathrm{MSBC}_{23}=11.214,72-7.865=$ & $3.349,72$ \\
\hline$M_{S B C}=11.894,40-9.752=$ & $2.142,40$ \\
\hline $\mathrm{MSBC}_{2}$ & $33.289,40$ \\
\hline
\end{tabular}

$(-) \quad$\begin{tabular}{rr|} 
Custos Variáveis \\
$\mathrm{CV}_{21}=0,00 \times 92=$ & - \\
$\mathrm{CV}_{22}=0,00 \times 75=$ & - \\
$\mathrm{CV}_{23}=0,00 \times 33=$ & - \\
$\mathrm{CV}_{24}=0,00 \times 35=$ & - \\
$\mathrm{CV}_{2}=$ & - \\
\hline
\end{tabular}

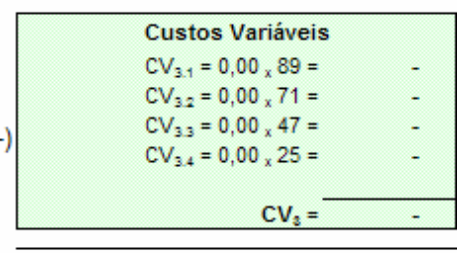

Margem Bruta de Contribuição $\mathrm{MBC}_{3.1}=30.245,76-0,00=30.245,76$ $\mathrm{MBC}_{32}=24.128,64-0,00=24.128,64$ $\mathrm{MBC}_{33}=15.972,48-0,00=15.972,48$ $\mathrm{MBC}_{3.4}=8.496,00-0,00=8.496,00$

$\mathrm{MBC}_{3}=78.842,88$

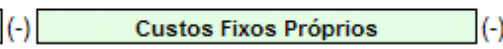

\begin{tabular}{|cr|}
\hline \multicolumn{2}{c|}{ Custos Fixos Próprios } \\
\hline Margem Semi-Bruta de Contribuição \\
$M_{\text {MSBC }}=30.245,76-13.764=$ & $16.481,76$ \\
$M_{3.1}=24.128,64-14.527=$ & $9.601,64$ \\
$M_{3 S B C}=15.972,48-7.901=$ & $8.071,48$ \\
$M_{3 S B C}=8.496,00-7.637=$ & 859,00 \\
$M_{3 S B C}=$ & $35.013,88$ \\
\hline
\end{tabular}

Atividade Identificada com o Produto 2 Atividade Identificada com o Produto 3

\begin{tabular}{|c|c|}
\hline $\begin{array}{c}\text { Custos de Despesas Fixas } \\
\text { Próprias }\end{array}$ & $\begin{array}{c}\text { Margem } \\
\text { Bruta de } \\
\text { Contribuição } \\
\text { Total do } \\
\text { Produto } \\
\text { MSBC Total do Produto } \\
18.474\end{array}$ \\
\hline \\
\hline
\end{tabular}

\section{Apuração do Resultado no Período - UEN 5}

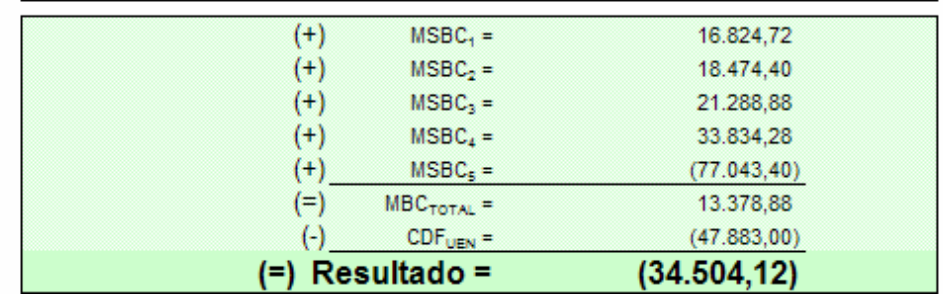


Figura 6.6 - Continuação
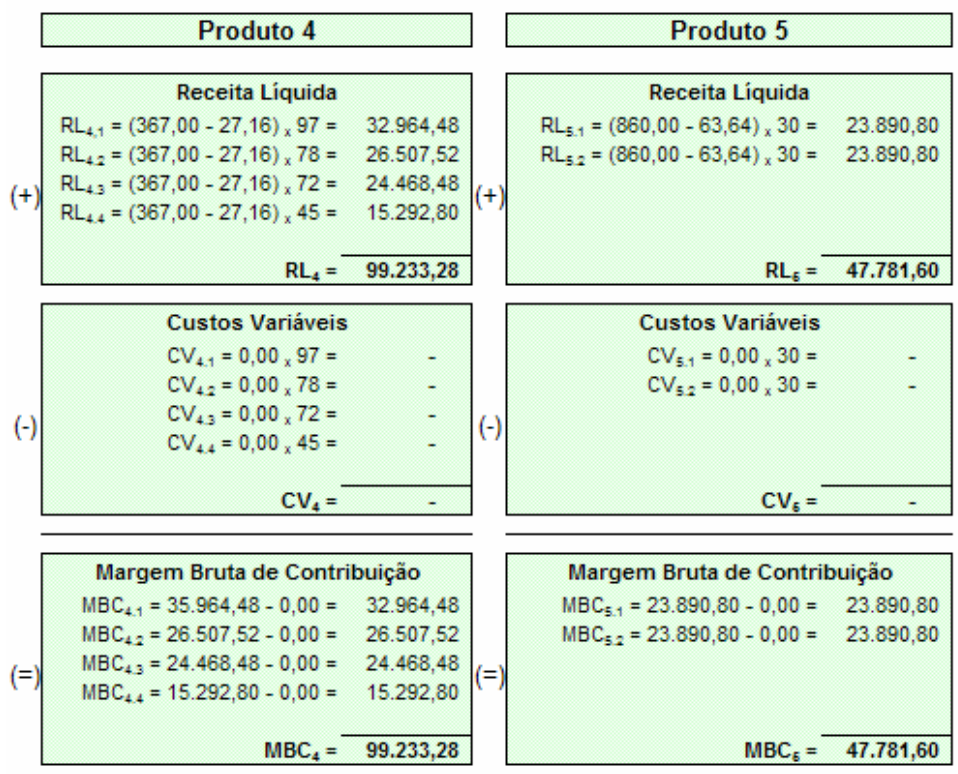

Margem Bruta de Contribuição

$\mathrm{MBC}_{5.1}=23.890,80-0,00=23.890,80$ $\mathrm{MBC}_{52}=23.890,80-0,00=23.890,80$

$(-)$

Custos Fixos Próprios

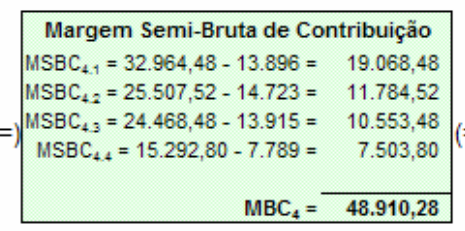

$(-)$

$\mathrm{MBC}_{6}=47.781,60$

Atividade Identificada com o Produto 4 Atividade Identificada com o Produto 5

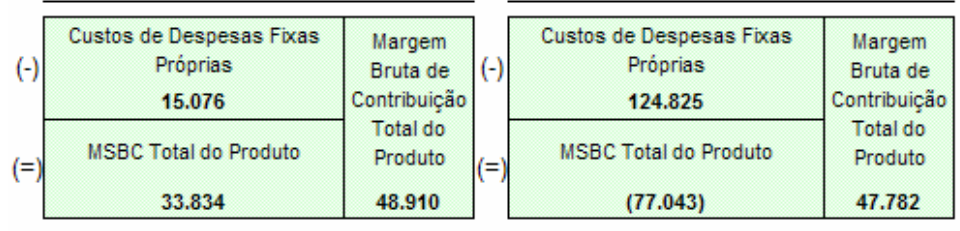

Semi-Bruta de Contribuição MSBC $_{51}=23,890,80-0,00=23.890,80$ MSBC $_{52}=23,890,80-0,00=23.890,80$ $\mathrm{MSBC}_{6}=\quad 47.781,60$ 


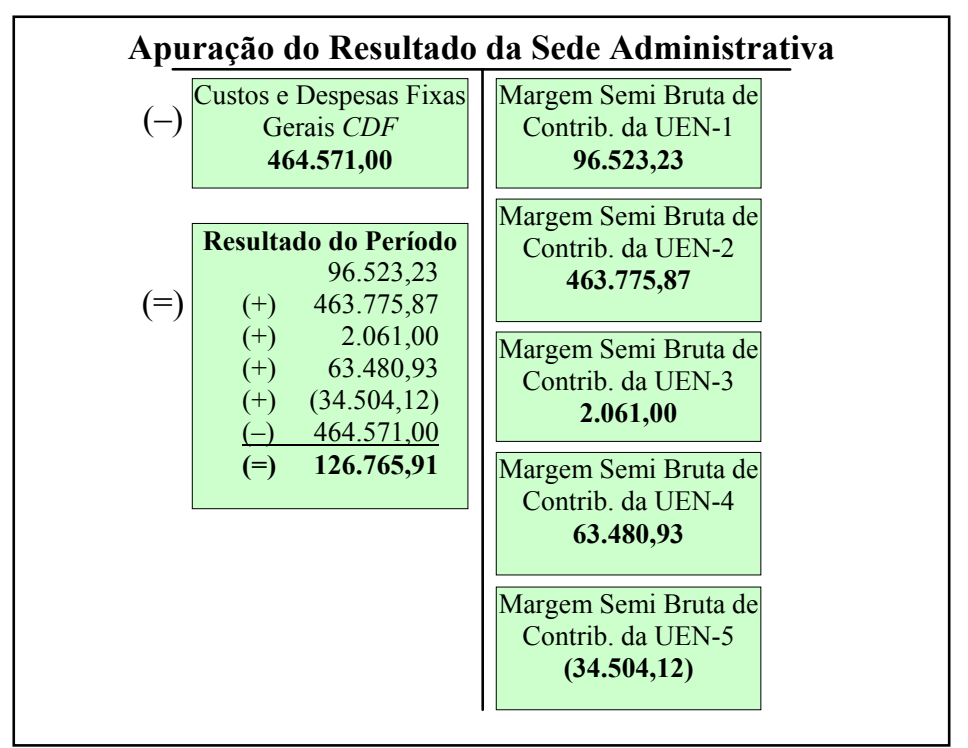

Figura 6.7 - Resolução da Sede Administrativa utilizando Representação Esquemática do Modelo Econômico.

A tabela abaixo apresenta a Receita Bruta de cada UEN e sua Margem SemiBruta de Contribuição. Pode-se perceber que mesmo a UEN-1 tendo a maior receita, sua contribuição para o todo é bastante tímida e que a UEN-5 opera em prejuízo devido ao Mestrado (uma exigência legal que a empresa tem que cumprir), pois sua receita é pequena comparada com as outras.

Percebe-se também que toda empresa apresenta um resultado global de $2 \%$, muito abaixo do esperado pelos seus dirigentes. Por outro lado, em comparação com resultados anteriores, percebe-se que o lucro vem aumentando devido a reestruturação da empresa.

Tabela 6.7 - Comparação da Receita Bruta x MSBC de cada UEN

\begin{tabular}{|l|c|c|c|c|c|}
\cline { 2 - 6 } \multicolumn{1}{c|}{} & UEN-1 & UEN-2 & UEN-3 & UEN-4 & UEN-5 \\
\hline Receita Bruta (R\$) & 2.625 .567 & 1.804 .580 & 247.622 & 1.087 .399 & 415.664 \\
\hline MSBC (R\$) & 96.523 & 463.776 & 2.061 & 63.481 & $(34.504)$ \\
\hline MSBC (\%) & $4 \%$ & $26 \%$ & $1 \%$ & $6 \%$ & $-8 \%$ \\
\hline
\end{tabular}




\subsection{CALCULO DOS INDICADORES DE POSIÇÃO ECONÔMICA}

A partir dos dados obtidos e das equações desenvolvidas no Capítulo-5, podese calcular todos os indicadores de posição econômica, que estão apresentados abaixo juntamente com sua análise.

A apresentação das equações e da forma de cálculo de todos os indicadores ficaria repetitivo pelo volume de dados e resultados gerados. Por isso optou-se pela demonstração do cálculo de um resultado por UEN.

\subsubsection{GAO dos Produtos por Mercado}

Tabela 6.8 - GAO dos Produtos da UEN-1 por Mercado

\begin{tabular}{|l|c|c|c|c|c|}
\hline \multicolumn{1}{|c|}{ GAO } & Mercado 1 & Mercado 2 & Mercado 3 & Mercado 4 & Mercado 5 \\
\hline GAO Produto 1 & 0,650 & 0,628 & 0,574 & 0,574 & 0,520 \\
\hline GAO Produto 2 & 0,908 & 0,816 & 0,789 & 0,724 & -- \\
\hline GAO Produto 3 & 0,230 & 0,129 & -- & -- & -- \\
\hline GAO Produto 4 & 0,128 & 0,092 & -- & -- & -- \\
\hline GAO Produto 5 & 1,368 & 1,361 & 1,334 & 1,341 & 1,355 \\
\hline GAO Produto 6 & 0,977 & 0,901 & 0,879 & 0,858 & 0,760 \\
\hline GAO Produto 7 & 0,841 & 0,709 & 0,559 & -- & -- \\
\hline GAO Produto 8 & 0,423 & 0,349 & 0,211 & 0,175 & -- \\
\hline GAO Produto 9 & 0,263 & 0,227 & 0,180 & -- & -- \\
\hline GAO Produto 10 & 0,316 & 0,254 & 0,185 & 0,100 & -- \\
\hline GAO Produto 11 & 0,570 & 0,505 & 0,469 & 0,368 & -- \\
\hline GAO Produto 12 & 0,205 & 0,205 & -- & -- & -- \\
\hline
\end{tabular}

\begin{tabular}{|c|}
\hline $\begin{array}{c}\text { Todos os } \\
\text { Mercados }\end{array}$ \\
\hline 2,946 \\
\hline 3,237 \\
\hline 0,358 \\
\hline 0,220 \\
\hline 6,759 \\
\hline 4,376 \\
\hline 2,110 \\
\hline 1,158 \\
\hline 0,670 \\
\hline 0,855 \\
\hline 1,913 \\
\hline 0,409 \\
\hline
\end{tabular}




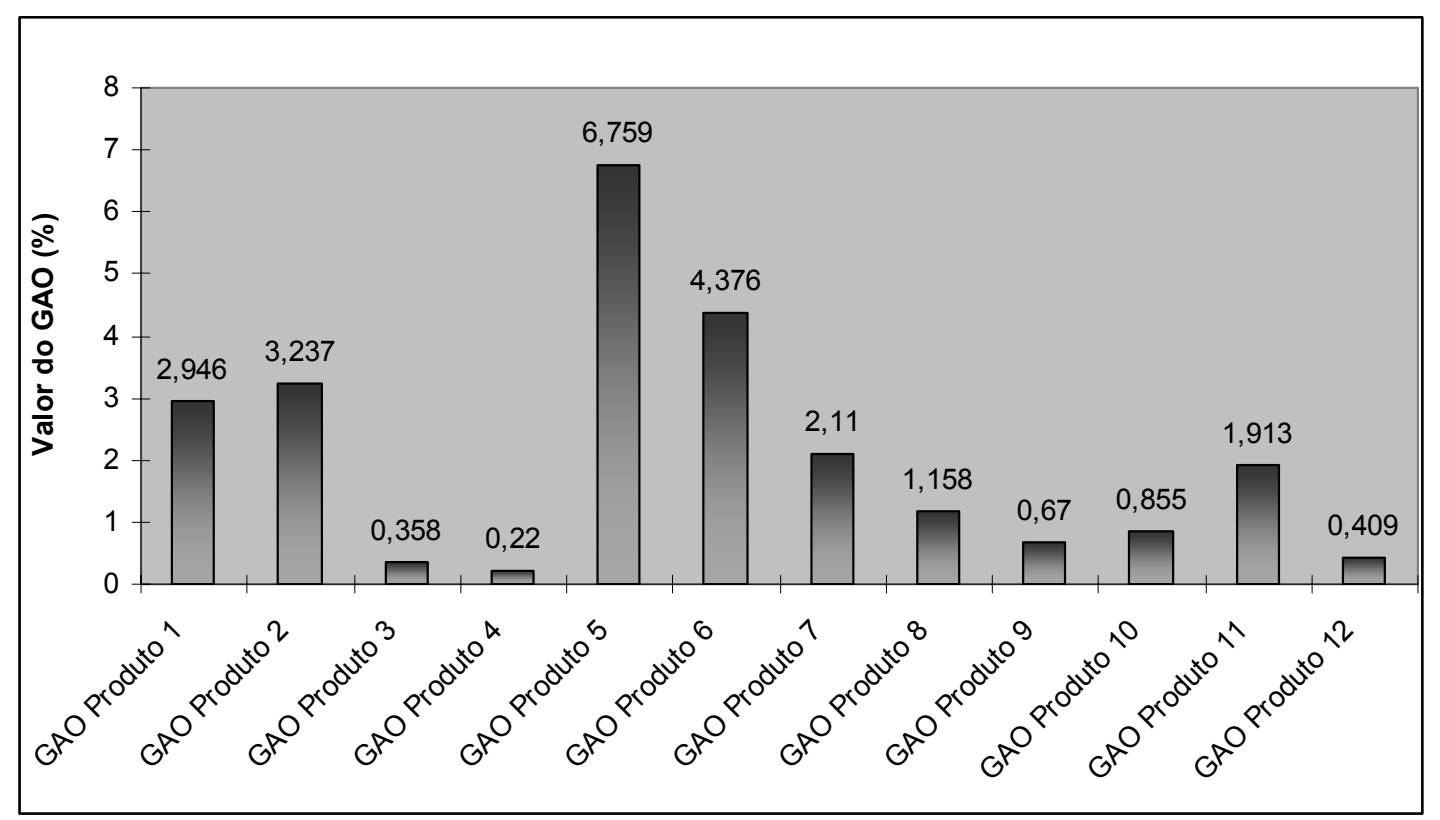

Figura 6.8 - Análise gráfica do GAO dos Produtos da UEN-1.

Conforme análise da tabela acima, o GAO do Produto-5 é o melhor, contrariando a análise da margem de contribuição realizada, que apresentava os produtos 1 e 6 como os melhores para melhorar o resultado da UEN. Através do GAO conclui-se que a cada $1 \%$ de aumento nas vendas do resultado da UEN-1 irá aumentar em 6,759\%, sendo que o Mercado-1 promove a maior contribuição.

Para o cálculo desses indicadores deve-se extrair a Margem de Contribuição e o Resultado da UEN contidos na Figura-6.2 (página 140) e utilizar as Equações-40 e 41 (página 104).

\section{GAO do Produto-5 no Mercado-1 - UEN-1}

$$
G A O_{\left(P_{51} / U E N_{1}\right)}=\frac{M B C_{51}}{R E S_{U E N-1}}=\frac{132.074,31}{96.523,23}=1,368
$$

\section{GAO do Produto-5 - UEN-1}

$$
G A O_{\left(P_{5} / U E N_{1}\right)}=\frac{\sum_{j=1}^{5} M B C_{5 j}}{R E S_{U E N-1}}=\frac{652.407,27}{96.523,23}=6,759
$$


Tabela 6.9 - GAO dos Produtos da UEN-2 por Mercado

\begin{tabular}{|c|c|c|c|c|c|c|}
\hline GAO & Mercado 1 & Mercado 2 & Mercado 3 & Mercado 4 & Mercado 5 & \begin{tabular}{|l|} 
Todos os \\
Mercados
\end{tabular} \\
\hline GAO Produto 1 & 0,416 & 0,336 & 0,326 & 0,267 & -- & 1,346 \\
\hline GAO Produto 2 & -- & 0,022 & 0,012 & 0,020 & -- & 0,054 \\
\hline GAO Produto 3 & 0,075 & 0,059 & 0,043 & 0,033 & -- & 0,210 \\
\hline GAO Produto 4 & 0,075 & 0,067 & 0,042 & 0,047 & -- & 0,230 \\
\hline GAO Produto 5 & 0,049 & 0,047 & 0,044 & 0,045 & -- & 0,184 \\
\hline GAO Produto 6 & 0,095 & 0,085 & 0,068 & 0,066 & -- & 0,314 \\
\hline GAO Produto 7 & 0,408 & 0,285 & 0,239 & 0,200 & -- & 1,132 \\
\hline GAO Produto 8 & -- & -- & 0,020 & 0,012 & -- & 0,031 \\
\hline GAO Produto 9 & 0,052 & 0,050 & -- & -- & -- & 0,101 \\
\hline
\end{tabular}

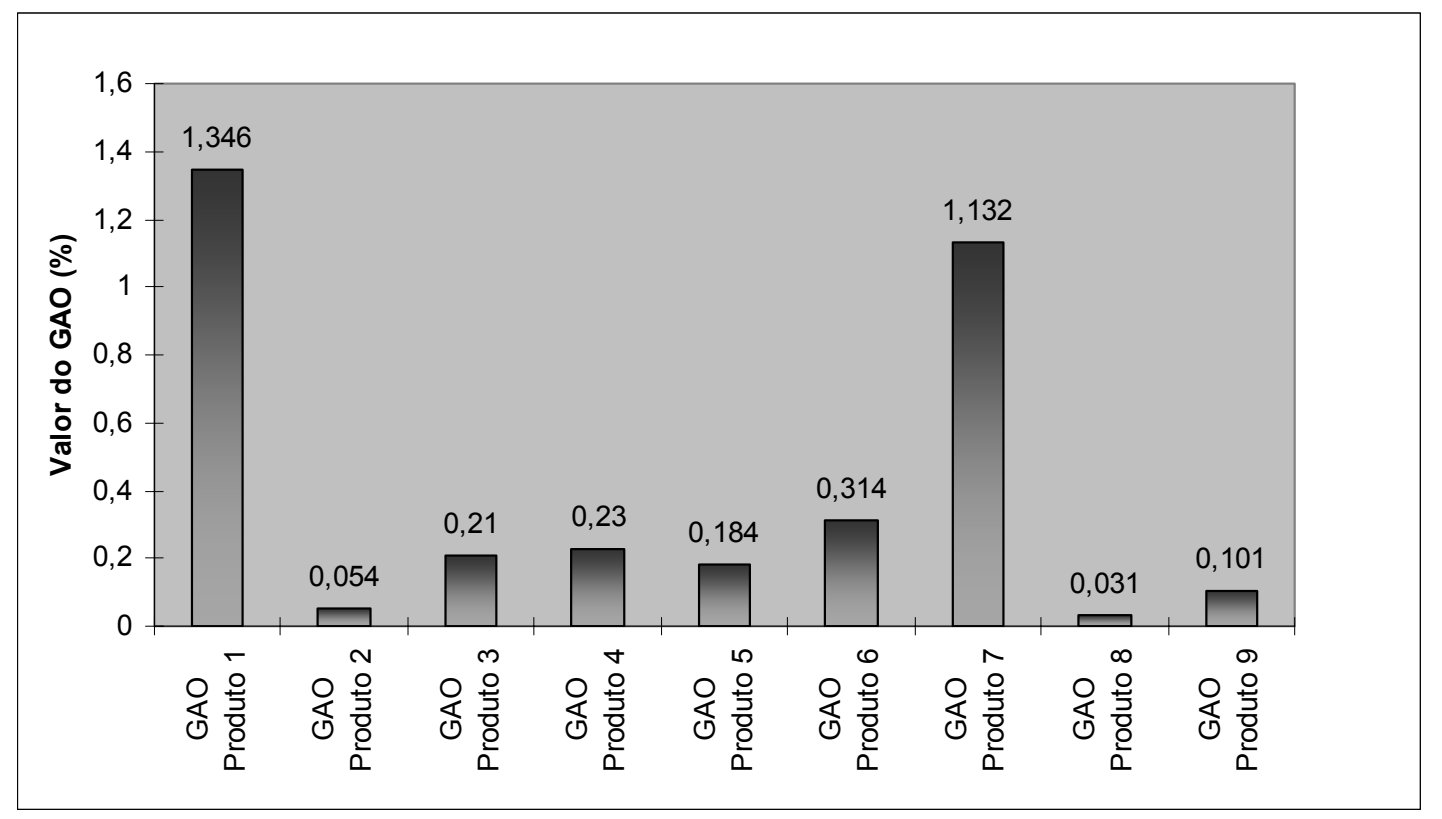

Figura 6.9 - Análise gráfica do GAO dos Produtos da UEN-2.

Conforme análise da tabela acima, o GAO do Produto-1 é o melhor, pois a cada $1 \%$ de aumento nas vendas do resultado da UEN-2 irá aumentar em 1,346\%, sendo que o Mercado-1 promove a maior contribuição. 
Para o cálculo desses indicadores deve-se extrair a Margem de Contribuição e o Resultado da UEN contidos na Figura-6.3 (página 141) e utilizar as Equações-40 e 41 (página 104).

\section{GAO do Produto-1 no Mercado-1 - UEN-2}

$$
G A O_{\left(P_{11} / U E N_{2}\right)}=\frac{M B C_{11}}{R E S_{U E N-2}}=\frac{193.010,88}{463.775,87}=0,416
$$

\section{GAO do Produto-1 - UEN-2}

$$
G A O_{\left(I_{1} / U E N_{2}\right)}=\frac{\sum_{j=1}^{4} M B C_{1 j}}{R E S_{U E N-2}}=\frac{624.128,64}{463.775,87}=1,346
$$

\begin{tabular}{|c|c|c|c|c|c|c|}
\hline GAO & Mercado 1 & Mercado 2 & Mercado 3 & Mercado 4 & Mercado 5 & \begin{tabular}{|l} 
Todos os \\
Mercados
\end{tabular} \\
\hline GAO Produto 1 & 24,587 & 16,391 & 13,282 & -- & -- & 54,260 \\
\hline GAO Produto 2 & 10,632 & 9,303 & 7,974 & -- & -- & 27,910 \\
\hline GAO Produto 3 & 10,693 & 9,624 & 8,769 & -- & -- & 29,086 \\
\hline
\end{tabular}

Tabela 6.10 - GAO dos Produtos da UEN-3 por Mercado

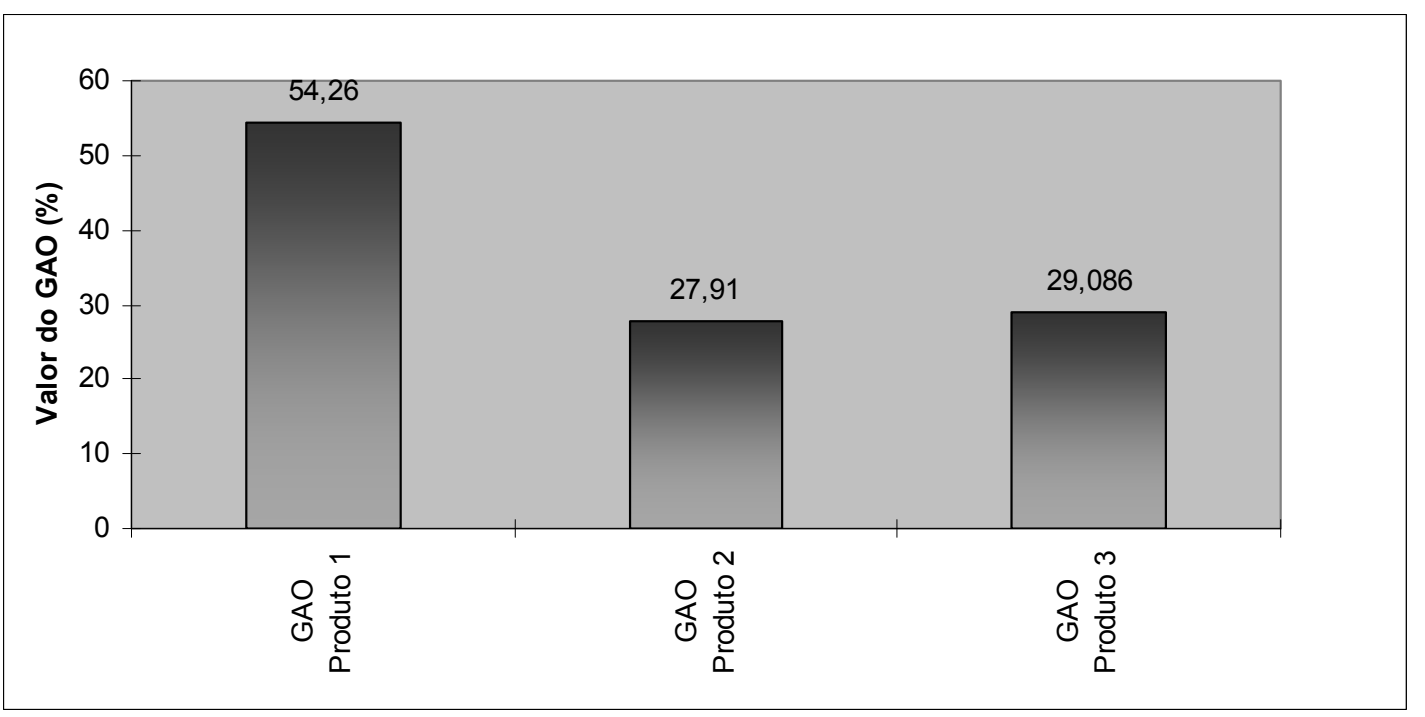

Figura 6.10 - Análise gráfica do GAO dos Produtos da UEN-3. 
Conforme análise da tabela acima, o GAO do Produto-1 é o melhor, pois a cada $1 \%$ de aumento nas vendas do resultado da UEN-3 irá aumentar em 54,260\%, sendo que o Mercado-1 promove a maior contribuição. Lembrando que um GAO muito alto corresponde a uma situação de risco, pois a MS é muito pequena, como será visto nas tabelas seguintes.

Para o cálculo desses indicadores deve-se extrair a Margem de Contribuição e o Resultado da UEN contidos na Figura-6.4 (página 142) e utilizar as Equações-40 e 41 (página 104).

\section{GAO do Produto-1 no Mercado-1 - UEN-3}

$$
G A O_{\left(P_{11} / U E N_{3}\right)}=\frac{M B C_{11}}{R E S_{U E N-3}}=\frac{50.673,15}{2.061,00}=24,587
$$

\section{GAO do Produto-1 - UEN-3}

$$
G A O_{\left(I_{1} / U E N_{3}\right)}=\frac{\sum_{j=1}^{3} M B C_{1 j}}{R E S_{U E N-3}}=\frac{111.830,40}{2.061,00}=54,260
$$

\begin{tabular}{|c|c|c|c|c|c|c|}
\hline GAO & Mercado 1 & Mercado 2 & Mercado 3 & Mercado 4 & Mercado 5 & \begin{tabular}{|l|} 
Todos os \\
Mercados \\
\end{tabular} \\
\hline GAO Produto 1 & 0,726 & 0,552 & 0,442 & 0,300 & 0,126 & 2,147 \\
\hline GAO Produto 2 & 0,438 & 0,411 & 0,333 & 0,149 & -- & 1,330 \\
\hline GAO Produto 3 & 1,275 & 1,055 & 1,093 & 0,819 & -- & 4,241 \\
\hline GAO Produto 4 & 0,710 & 0,505 & 0,347 & 0,284 & 0,174 & 2,020 \\
\hline GAO Produto 5 & 0,789 & 0,600 & 0,395 & 0,363 & 0,237 & 2,383 \\
\hline GAO Produto 6 & 0,600 & 0,395 & 0,316 & 0,284 & 0,110 & 1,705 \\
\hline GAO Produto 7 & -- & 0,182 & 0,123 & 0,043 & -- & 0,348 \\
\hline GAO Produto 8 & 0,252 & 0,198 & 0,150 & 0,118 & -- & 0,717 \\
\hline GAO Produto 9 & 0,403 & 0,289 & 0,166 & 0,114 & -- & 0,971 \\
\hline
\end{tabular}

Tabela 6.11 - GAO dos Produtos da UEN-4 por Mercado 


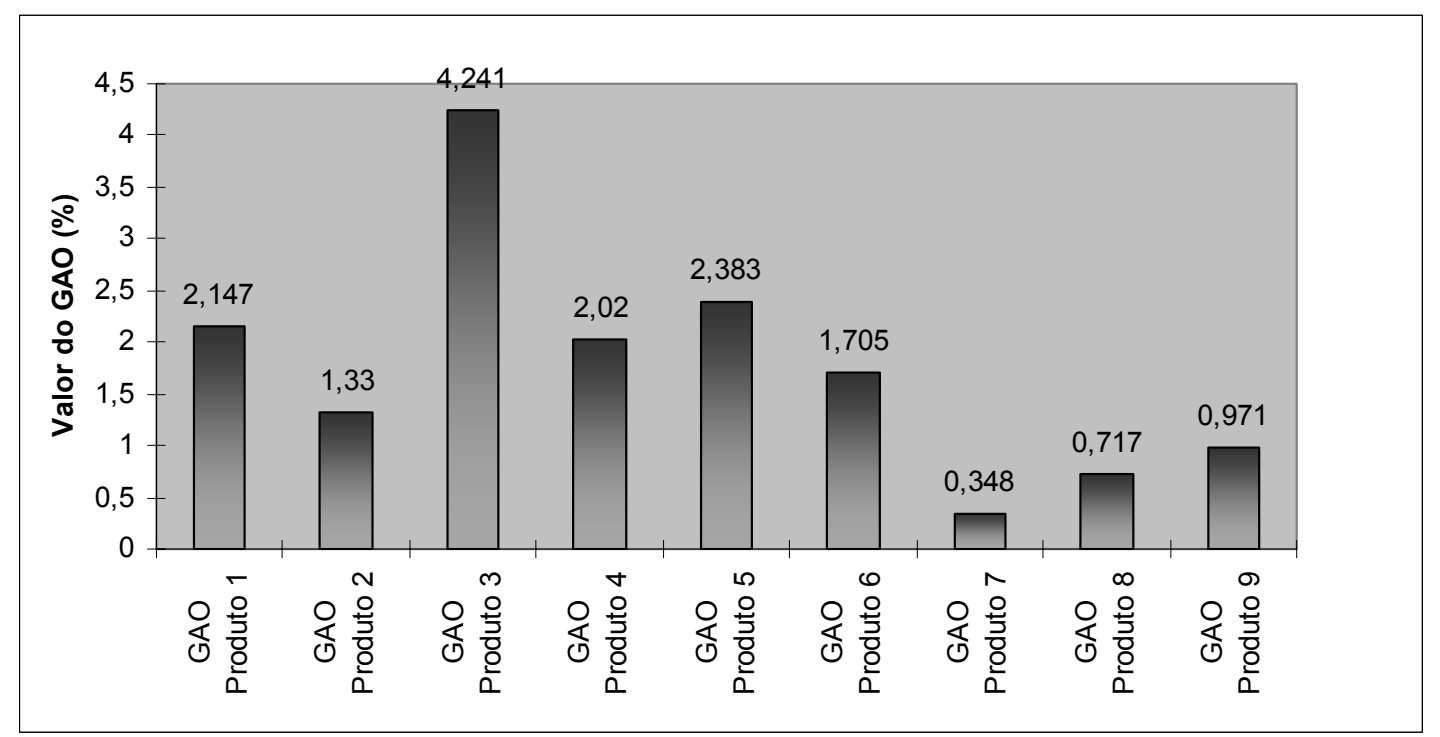

Figura 6.11 - Análise gráfica do GAO dos Produtos da UEN-4.

Conforme análise da tabela acima, o GAO do Produto-3 é o melhor, pois a cada $1 \%$ de aumento nas vendas do resultado da UEN-4 irá aumentar em 4,241\%, sendo que o Mercado-1 promove a maior contribuição.

Para o cálculo desses indicadores deve-se extrair a Margem de Contribuição e o Resultado da UEN contidos na Figura-6.5 (página 143) e utilizar as Equações-40 e 41 (página 104).

\section{GAO do Produto-3 no Mercado-1 - UEN-4}

$$
G A O_{\left(P_{31} / U E N_{4}\right)}=\frac{M B C_{31}}{R E S_{U E N-4}}=\frac{80.912,16}{63.480,93}=1,275
$$

\section{GAO do Produto-3 - UEN-4}

$$
G A O_{\left(P_{3} / U E N_{4}\right)}=\frac{\sum_{j=1}^{4} M B C_{3 j}}{R E S_{U E N-4}}=\frac{269.225,58}{63.480,93}=4,241
$$


Tabela 6.12 - GAO dos Produtos da UEN-5 por Mercado

\begin{tabular}{|c|c|c|c|c|c|c|}
\hline GAO & Mercado 1 & Mercado 2 & Mercado 3 & Mercado 4 & Mercado 5 & \begin{tabular}{|l|} 
Todos os \\
Mercados
\end{tabular} \\
\hline GAO Produto 1 & $-0,857$ & $-0,670$ & $-0,443$ & $-0,325$ & -- & $-2,295$ \\
\hline GAO Produto 2 & $-0,906$ & $-0,739$ & $-0,325$ & $-0,345$ & -- & $-2,315$ \\
\hline GAO Produto 3 & $-0,877$ & $-0,699$ & $-0,463$ & $-0,246$ & -- & $-2,285$ \\
\hline GAO Produto 4 & $-0,955$ & $-0,768$ & $-0,709$ & $-0,443$ & -- & $-2,876$ \\
\hline GAO Produto 5 & $-0,692$ & $-0,692$ & -- & -- & -- & $-1,385$ \\
\hline
\end{tabular}

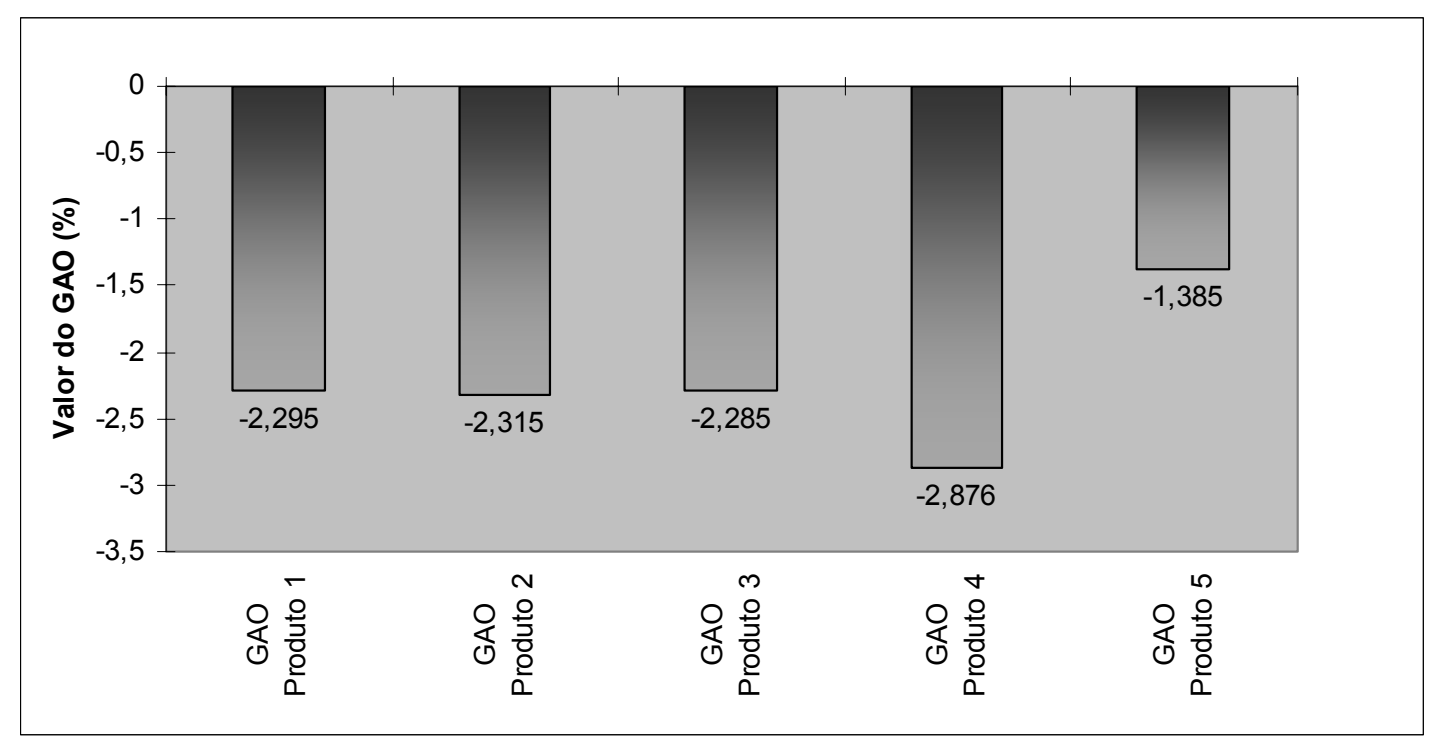

Figura 6.12 - Análise gráfica do GAO dos Produtos da UEN-5.

A análise desses indicadores deve ser realizada tomando a Tabela-5.3 como referência, sabendo que a UEN opera com Resultado negativo e todos os produtos possuem MBC positiva, estando os resultados no quadrante 2 da referida tabela. Nesse contexto, o Produto-4 mostra-se melhor, pois a cada $1 \%$ de aumento nas vendas o prejuízo da UEN-5 irá reduzir em 2,876\%, sendo que o Mercado-1 promove a maior contribuição.

Para o cálculo desses indicadores deve-se extrair a Margem de Contribuição e o Resultado da UEN contidos na Figura-6.6 (página 144) e utilizar as Equações-40 e 41 (página 104). 
GAO do Produto-4 no Mercado-1 - UEN-5

$$
G A O_{(P 41 / U E N 5)}=\frac{M B C_{41}}{R E S_{U E N-5}}=\frac{32 \cdot 964,48}{(34 \cdot 504,12)}=-0,955
$$

\section{GAO do Produto-4 - UEN-5}

$$
G A O_{\left(P_{4} / U E N 5\right)}=\frac{\sum_{j=1}^{4} M B C_{4 j}}{R E S_{U E N-5}}=\frac{99.233,28}{(34.504,12)}=2,876
$$

\subsubsection{GAOC dos Produtos por Mercado}

Conforme pode-se perceber nas análises realizada a partir das tabelas abaixo, o comportamento do GAOC segue do GAO, pois os produtos com maior GAO também possuem o maior GAOC no nível de mercado.

\begin{tabular}{|c|c|c|c|c|c|c|}
\hline GAOC & Mercado 1 & Mercado 2 & Mercado 3 & Mercado 4 & Mercado 5 & \begin{tabular}{|l|} 
Todos os \\
Mercados
\end{tabular} \\
\hline GAOC Produto 1 & 0,495 & 0,478 & 0,437 & 0,437 & 0,396 & 2,243 \\
\hline GAOC Produto 2 & 0,691 & 0,621 & 0,600 & 0,552 & -- & 2,465 \\
\hline $\mathrm{GAOC}_{\text {Produto } 3}$ & 0,175 & 0,098 & -- & -- & -- & 0,273 \\
\hline GAOC Produto 4 & 0,098 & 0,070 & -- & -- & -- & 0,168 \\
\hline GAOC Produto 5 & 1,042 & 1,037 & 1,016 & 1,021 & 1,031 & 5,147 \\
\hline GAOC Produto 6 & 0,744 & 0,686 & 0,670 & 0,653 & 0,579 & 3,332 \\
\hline GAOC Produto 7 & 0,641 & 0,540 & 0,426 & -- & -- & 1,606 \\
\hline $\mathrm{GAOC}_{\text {Produto } 8}$ & 0,322 & 0,266 & 0,161 & 0,133 & -- & 0,882 \\
\hline GAOC Produto 9 & 0,201 & 0,173 & 0,137 & -- & -- & 0,510 \\
\hline GAOC Produto 10 & 0,240 & 0,194 & 0,141 & 0,076 & -- & 0,651 \\
\hline $\mathrm{GAOC}_{\text {Produto } 11}$ & 0,434 & 0,385 & 0,357 & 0,280 & -- & 1,457 \\
\hline GAOC Produto 12 & 0,156 & 0,156 & -- & -- & -- & 0,312 \\
\hline
\end{tabular}

Tabela 6.13 - GAOC dos Produtos da UEN-1 por Mercado 


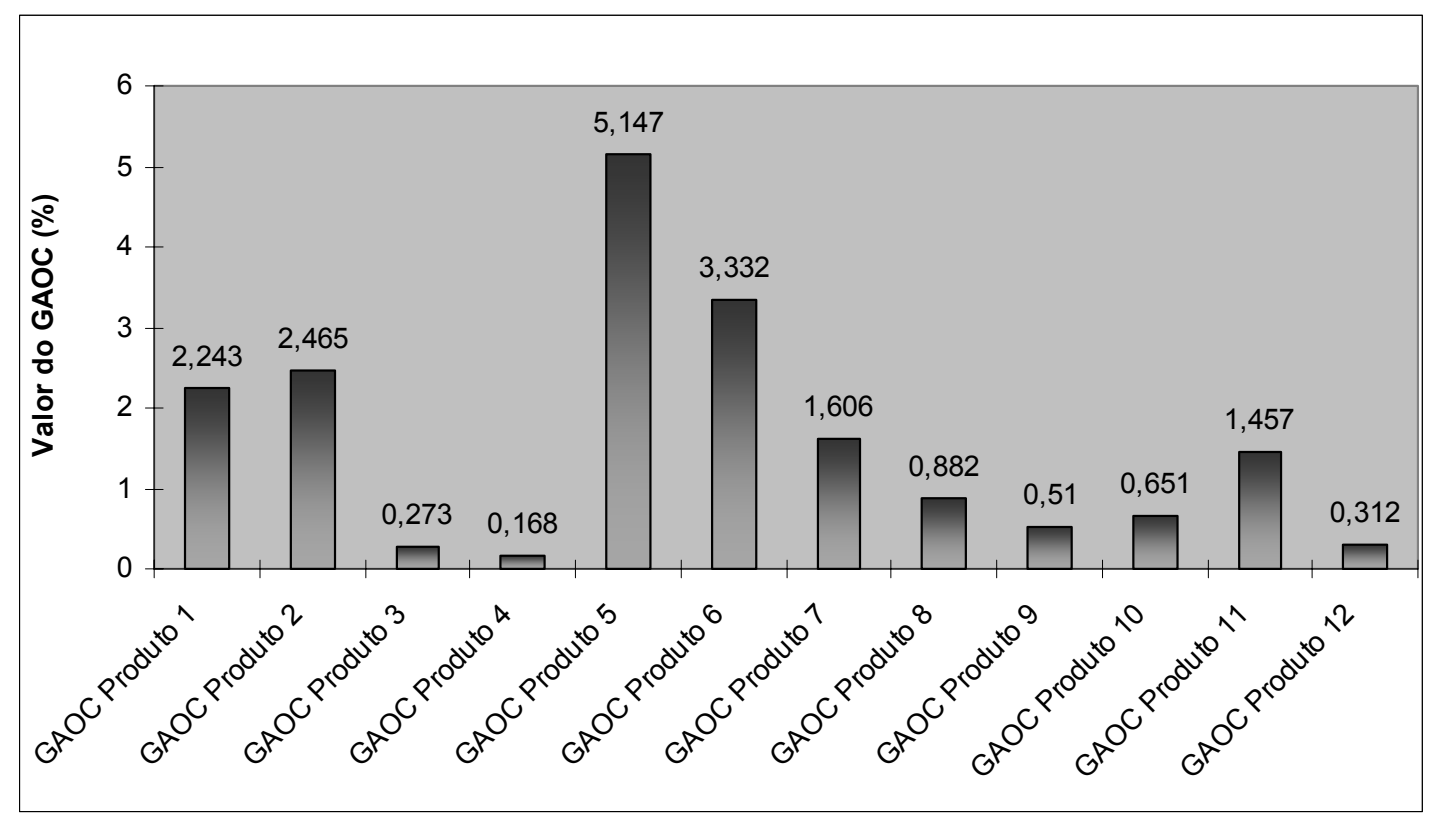

Figura 6.13 - Análise gráfica do GAOC dos Produtos da UEN-1.

Conforme análise da tabela acima, o GAOC do Produto-5 é o melhor, pois a cada $1 \%$ de aumento nas vendas do resultado da Sede Administrativa irá aumentar em 5,147\%, sendo que o Mercado-1 promove a maior contribuição.

Para o cálculo desses indicadores deve-se extrair a Margem de Contribuição da Figura-6.2 (página 140), o Resultado da Sede Administrativa da Figura-6.7 (página 145) e utilizar a Equação-87 (página 106) e a Equação-90 (página 107).

\section{GAOC do Produto-5 no Mercado-1 - UEN-1}

$$
\operatorname{GAOC}_{\left(P_{51} / U E N_{1}\right)_{S E D E}}=\frac{M B C_{51}}{R E S_{S E D E}}=\frac{132.074,31}{126.765,91}=1,042
$$

\section{GAOC do Produto-5 - UEN-1}

$$
\operatorname{GAOC}_{\left(P_{5} / U E N_{1}\right)_{S E D E}}=\frac{\sum_{j=1}^{5} M B C_{5 j}}{R E S_{S E D E}}=\frac{652.407,27}{126.765,91}=5,147
$$


Tabela 6.14 - GAOC dos Produtos da UEN-2 por Mercado

\begin{tabular}{|c|c|c|c|c|c|c|}
\hline GAOC & Mercado 1 & Mercado 2 & Mercado 3 & Mercado 4 & Mercado 5 & \begin{tabular}{|l|} 
Todos os \\
Mercados \\
\end{tabular} \\
\hline GAOC Produto 1 & 1,523 & 1,231 & 1,192 & 0,978 & -- & 4,923 \\
\hline GAOC Produto 2 & -- & 0,080 & 0,045 & 0,074 & -- & 0,199 \\
\hline GAOC Produto 3 & 0,273 & 0,215 & 0,157 & 0,122 & -- & 0,768 \\
\hline GAOC Produto 4 & 0,274 & 0,245 & 0,153 & 0,171 & -- & 0,843 \\
\hline GAOC Produto 5 & 0,178 & 0,171 & 0,160 & 0,164 & -- & 0,674 \\
\hline GAOC Produto 6 & 0,349 & 0,310 & 0,248 & 0,241 & -- & 1,149 \\
\hline $\mathrm{GAOC}_{\text {Produto } 7}$ & 1,492 & 1,043 & 0,873 & 0,732 & -- & 4,140 \\
\hline GAOC Produto 8 & -- & -- & 0,072 & 0,043 & -- & 0,115 \\
\hline GAOC Produto 9 & 0,188 & 0,182 & -- & -- & -- & 0,371 \\
\hline
\end{tabular}

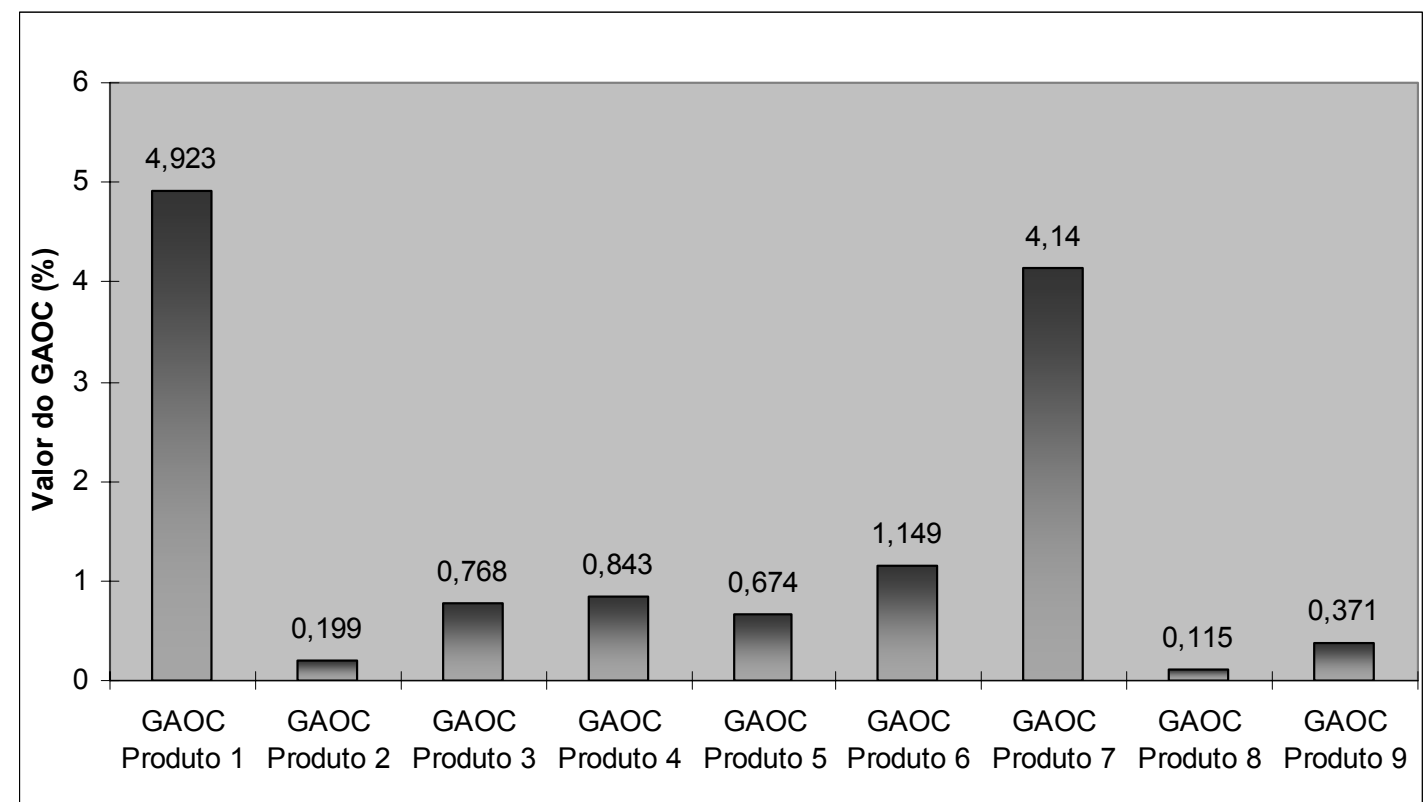

Figura 6.14 - Análise gráfica do GAOC dos Produtos da UEN-2.

Conforme análise da tabela acima, o GAOC do Produto-1 é o melhor, pois a cada $1 \%$ de aumento nas vendas do resultado da Sede Administrativa irá aumentar em 4,923\%, sendo que o Mercado-1 promove a maior contribuição.

Para o cálculo desses indicadores deve-se extrair a Margem de Contribuição da Figura-6.3 (página 141), o Resultado da Sede Administrativa da Figura-6.7 (página 145) e utilizar a Equação-87 (página 106) e a Equação-90 (página 107). 
GAOC do Produto-1 no Mercado-1 - UEN-2

$$
\operatorname{GAOC}_{\left(P_{11} / U E N_{2}\right)_{S E D E}}=\frac{M B C_{11}}{R E S_{S E D E}}=\frac{193.010,88}{126.765,91}=1,523
$$

\section{GAOC do Produto-1 - UEN-2}

$$
\operatorname{GAOC}_{\left(\mathcal{P}_{1} / U E N_{2}\right)_{S E D E}}=\frac{\sum_{j=1}^{4} M B C_{1 j}}{R E S_{S E D E}}=\frac{624 \cdot 128,64}{126.765,91}=4,923
$$

\begin{tabular}{|c|c|c|c|c|c|c|}
\hline GAO & Mercado 1 & Mercado 2 & Mercado 3 & Mercado 4 & Mercado 5 & $\begin{array}{l}\text { Todos os } \\
\text { Mercados }\end{array}$ \\
\hline GAOC Produto 1 & 0,400 & 0,266 & 0,216 & -- & -- & 0,882 \\
\hline $\mathrm{GAOC}_{\text {Produto } 2}$ & 0,173 & 0,151 & 0,130 & -- & -- & 0,454 \\
\hline $\mathrm{GAOC}_{\text {Proc }}$ & 0,174 & 0,156 & 0,143 & -- & -- & 0,473 \\
\hline
\end{tabular}

Tabela 6.15 - GAOC dos Produtos da UEN-3 por Mercado

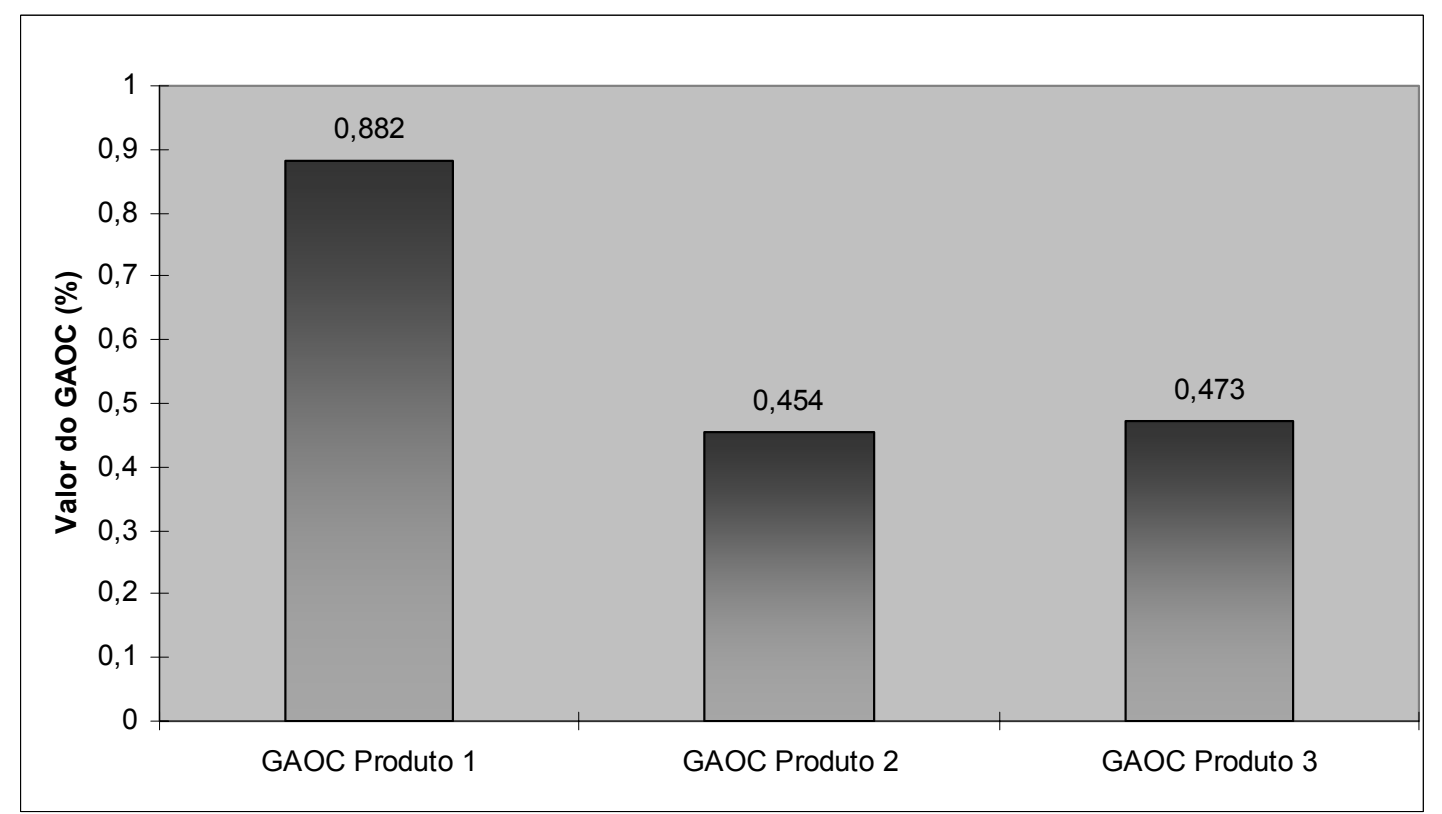

Figura 6.15 - Análise gráfica do GAOC dos Produtos da UEN-3. 
Conforme análise da tabela anterior, o GAOC do Produto-1 é o melhor, pois a cada $1 \%$ de aumento nas vendas do resultado da Sede Administrativa irá aumentar em $0,882 \%$, sendo que o Mercado-1 promove a maior contribuição.

Para o cálculo desses indicadores deve-se extrair a Margem de Contribuição da Figura-6.4 (página 142), o Resultado da Sede Administrativa da Figura-6.7 (página 145) e utilizar a Equação-87 (página 106) e a Equação-90 (página 107).

\section{GAOC do Produto-1 no Mercado-1 - UEN-3}

$$
\operatorname{GAOC}_{\left({ }_{11} / U E N_{3}\right)_{S E D E}}=\frac{M B C_{11}}{R E S_{S E D E}}=\frac{50.673,15}{126.765,91}=0,400
$$

\section{GAOC do Produto-1 - UEN-3}

$$
\operatorname{GAOC}_{\left(\Gamma_{1} / U E N_{3}\right)} \operatorname{SEDE}=\frac{\sum_{j=1}^{3} M B C_{1 j}}{R E S_{S E D E}}=\frac{111.830,40}{126.765,91}=0,882
$$

\begin{tabular}{|c|c|c|c|c|c|c|}
\hline GAO & Mercado 1 & Mercado 2 & Mercado 3 & Mercado 4 & Mercado 5 & \begin{tabular}{|l|} 
Todos os \\
Mercados
\end{tabular} \\
\hline GAOC Produto 1 & 0,364 & 0,277 & 0,221 & 0,150 & 0,063 & 1,075 \\
\hline GAOC Produto 2 & 0,219 & 0,206 & 0,167 & 0,075 & -- & 0,666 \\
\hline GAOC Produto 3 & 0,638 & 0,528 & 0,547 & 0,410 & -- & 2,124 \\
\hline GAOC Produto 4 & 0,356 & 0,253 & 0,174 & 0,142 & 0,087 & 1,012 \\
\hline GAOC Produto 5 & 0,395 & 0,300 & 0,198 & 0,182 & 0,119 & 1,193 \\
\hline $\mathrm{GAOC}_{\text {Produto } 6}$ & 0,300 & 0,198 & 0,158 & 0,142 & 0,055 & 0,854 \\
\hline $\mathrm{GAOC}_{\text {Produto } 7}$ & -- & 0,091 & 0,062 & 0,021 & -- & 0,174 \\
\hline GAOC Produto 8 & 0,126 & 0,099 & 0,075 & 0,059 & -- & 0,359 \\
\hline GAOC Produto 9 & 0,202 & 0,145 & 0,083 & 0,057 & -- & 0,486 \\
\hline
\end{tabular}

Tabela 6.16 - GAOC dos Produtos da UEN-4 por Mercado 


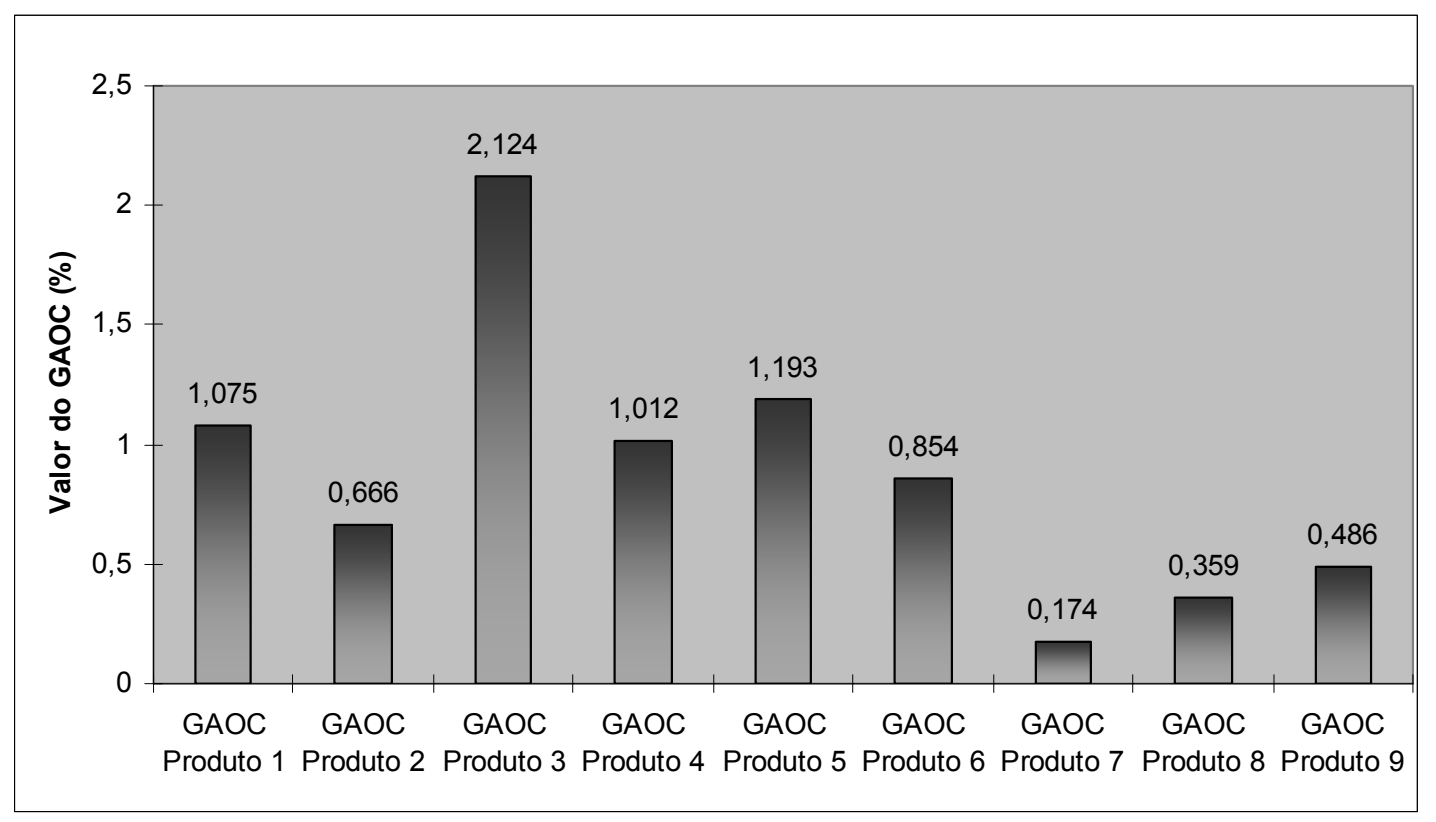

Figura 6.16 - Análise gráfica do GAOC dos Produtos da UEN-4.

Conforme análise da tabela acima, o GAOC do Produto-3 é o melhor, pois a cada $1 \%$ de aumento nas vendas do resultado da Sede Administrativa irá aumentar em 2,124\%, sendo que o Mercado-1 promove a maior contribuição.

Para o cálculo desses indicadores deve-se extrair a Margem de Contribuição da Figura-6.5 (página 143), o Resultado da Sede Administrativa da Figura-6.7 (página 145) e utilizar a Equação-87 (página 106) e a Equação-90 (página 107).

\section{GAOC do Produto-3 no Mercado-1 - UEN-4}

$$
\operatorname{GAOC}_{\left(P_{31} / U E N 4\right)_{S E D E}}=\frac{M B C_{31}}{R E S_{S E D E}}=\frac{80.912,16}{126.765,91}=0,638
$$

\section{GAOC do Produto-3 - UEN-4}

$$
\operatorname{GAOC}_{\left(P_{3} / U E N_{4}\right)_{S E D E}}=\frac{\sum_{j=1}^{4} M B C_{3 j}}{R E S_{S E D E}}=\frac{269.225,58}{126.765,91}=2,124
$$


Tabela 6.17 - GAOC dos Produtos da UEN-5 por Mercado

\begin{tabular}{|c|c|c|c|c|c|c|}
\hline GAO & Mercado 1 & Mercado 2 & Mercado 3 & Mercado 4 & Mercado 5 & \begin{tabular}{|l|} 
Todos os \\
Mercados
\end{tabular} \\
\hline GAOC Produto 1 & 0,233 & 0,182 & 0,121 & 0,088 & -- & 0,625 \\
\hline GAOC Produto 2 & 0,247 & 0,201 & 0,088 & 0,094 & -- & 0,630 \\
\hline GAOC Produto 3 & 0,239 & 0,190 & 0,126 & 0,067 & -- & 0,622 \\
\hline GAOC Produto 4 & 0,260 & 0,209 & 0,193 & 0,121 & -- & 0,783 \\
\hline GAOC Produto 5 & 0,188 & 0,188 & -- & -- & -- & 0,377 \\
\hline
\end{tabular}

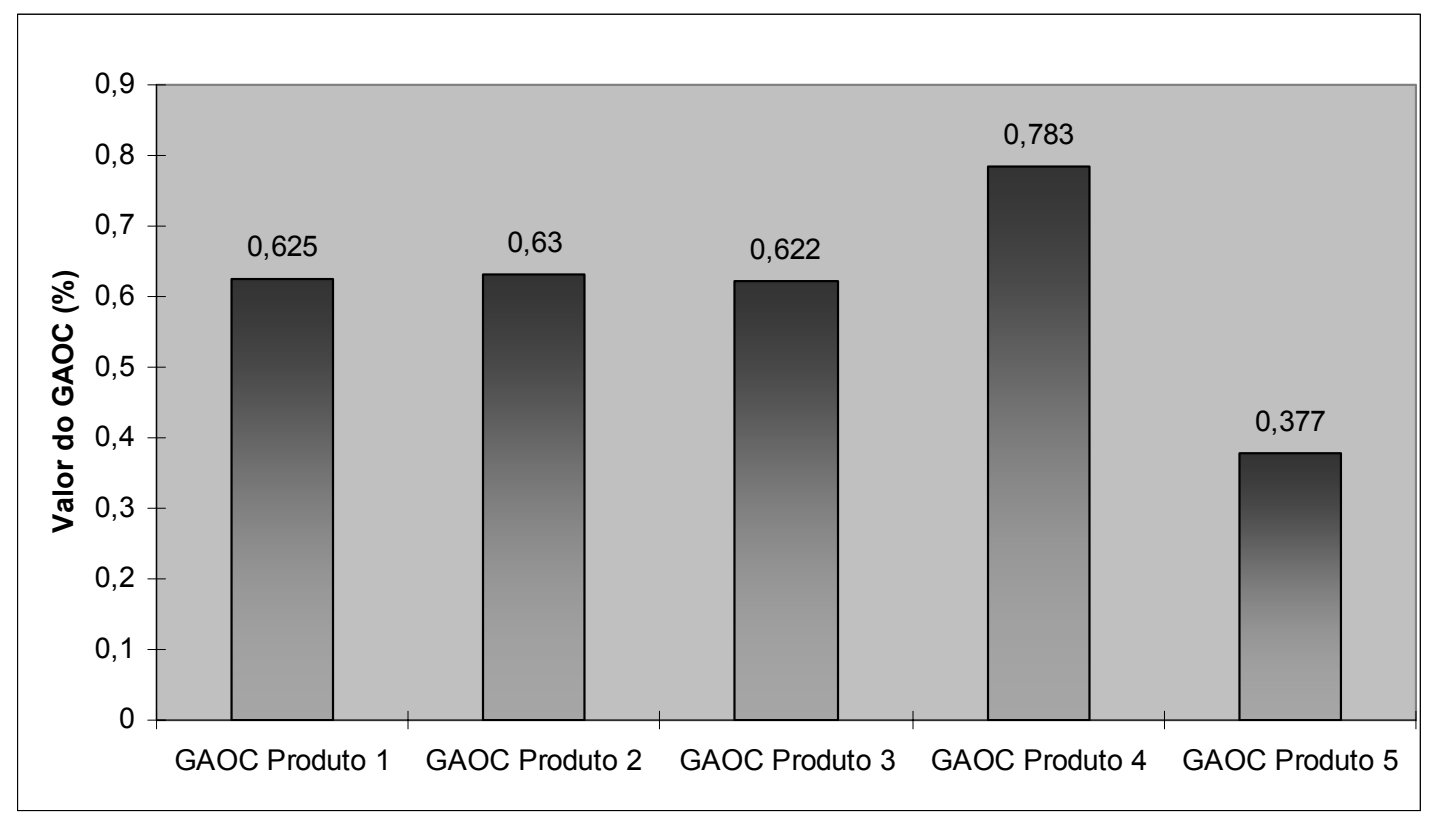

Figura 6.17 - Análise gráfica do GAOC dos Produtos da UEN-5.

Conforme análise da tabela acima, o GAOC do Produto-4 é o melhor, pois a cada $1 \%$ de aumento nas vendas do resultado da Sede Administrativa irá aumentar em $0,783 \%$, sendo que o Mercado-1 promove a maior contribuição.

Para o cálculo desses indicadores deve-se extrair a Margem de Contribuição da Figura-6.6 (página 144), o Resultado da Sede Administrativa da Figura-6.7 (página 145) e utilizar a Equação-87 (página 106) e a Equação-90 (página 107). 
GAOC do Produto-4 no Mercado-1 - UEN-5

$$
\operatorname{GAOC}_{\left(P_{41} / U E N 5\right)}{ }_{S E D E}=\frac{M B C_{41}}{R E S_{S E D E}}=\frac{32.964,48}{126.765,91}=0,260
$$

\section{GAOC do Produto-4 - UEN-5}

$$
\operatorname{GAOC}_{\left(P_{4} / U E N 5\right)} \operatorname{SEDE}=\frac{\sum_{j=1}^{4} M B C_{4 j}}{R E S_{S E D E}}=\frac{99.233,28}{126.765,91}=0,783
$$

\subsubsection{GAO e GAOC das UEN's}

Percebe-se na tabela abaixo a partir da comparação do GAO e do GAOC das UENs que um elevado GAO para uma determinada UEN não corresponde, necessariamente, a um elevado GAOC. Isso mostra que esses indicadores não possuem uma relação direta, pois se uma UEN possui um elevado GAO não necessariamente terá um elevado GAOC.

Tabela 6.18 - GAO e GAOC das UEN's

\begin{tabular}{|l|c|c|}
\hline \multicolumn{1}{|c|}{ UEN'S } & GAO & GAOC \\
\hline UEN 1 & 25,011 & 19,044 \\
\hline UEN 2 & 3,603 & 13,182 \\
\hline UEN 3 & 111,256 & 1,809 \\
\hline UEN 4 & 15,863 & 7,944 \\
\hline UEN 5 & $-11,155$ & 3,036 \\
\hline Todas as UEN'S & 144,578 & 45,015 \\
\hline
\end{tabular}

Quando se deseja aumentar o lucro da empresa, deve-se levar em consideração o GAOC, nesse sentido, um aumento de $1 \%$ nas vendas da UEN-1 corresponde a um aumento $25,011 \%$ nos lucros dessa UEN e $19,044 \%$ nos lucros de toda a empresa. 
Portanto, sob a ótica da Sede Administrativa, para decidir em qual UEN devese investir para aumentar as vendas, o indicador a ser utilizado é o GAOC, e não o GAO. Nesse caso específico deve-se escolher a UEN-1 seguida da UEN-2, pois são respectivamente os maiores indicadores.

Conclui-se que o GAO é um indicador importante auxílio à tomada de decisão no nível das UENs e o GAOC para a empresa toda.

\section{GAO da UEN-1}

Para o cálculo do GAO da UEN-1 deve-se extrair a Margem de Contribuição e o Resultado da UEN contidos na Figura-6.2 (página 140) e utilizar a Equação-84 (página 105).

$$
\begin{aligned}
G A O_{U E N_{1}} & =\frac{\sum_{j=1}^{5} \sum_{i=1}^{12} M B C_{i j}}{R E S_{U E N-1}}=\frac{284.373,28+312.436,77+\ldots .+39.502,00}{96.523,23} \\
G A O_{U E N_{1}} & =\frac{2.414 .172,23}{96.523,23}=25,011
\end{aligned}
$$

\section{GAOC da UEN-1}

Para o cálculo desses indicadores deve-se extrair a Margem de Contribuição da Figura-6.2 (página 140), o Resultado da Sede Administrativa da Figura-6.7 (página 145) e utilizar a Equação-43 (página 106).

$$
\begin{aligned}
\operatorname{GAOC}_{\left(U E N_{1}\right)_{S E D E}}= & \frac{\sum_{j=1}^{5} \sum_{i=1}^{12} M B C_{i j}}{R E S_{S E D E}}=\frac{284.373,28+312.436,77+\ldots .+39.502,00}{126.765,91} \\
\operatorname{GAOC}_{\left(U E N_{1}\right)_{S E D E}} & =\frac{2.414 .172,23}{126.765,91}=19,044
\end{aligned}
$$




\subsubsection{Margem de Segurança das UENS}

Quanto maior a margem de segurança maior a diferença entre a quantidade vendida e o ponto de equilíbrio, significando menor risco para a empresa. Percebe-se que a UEN-2 possui a situação mais confortável segundo este indicador.

Tabela 6.19 - MS das UEN's

\begin{tabular}{|c|c|}
\hline UEN'S & MS \\
\hline UEN 1 & $1 / 25,011=4,00$ \\
\hline UEN 2 & $1 / 3,603=27,75$ \\
\hline UEN 3 & $1 / 111,256=0,90$ \\
\hline UEN 4 & $1 / 15,863=6,30$ \\
\hline UEN 5 & $1 /-11,155=-8,96$ \\
\hline
\end{tabular}

\subsubsection{Ponto de Equilíbrio}

Quando os produtos possuem custos e despesas fixas no Nível-1 (mercado), pode-se calcular o Ponto de Equilíbrio do produto nesse mercado específico através da Equação-92 (página 110). O resultado desse cálculo pode ser interpretado como a quantidade mínima necessária a ser vendida para que esse produto consiga pagar o CDF do mercado e apresentar uma Margem Semi-Bruta de Contribuição positiva.

Como, especificamente para esse estudo de caso, todos os produtos possuem CDF em todos os mercados onde são vendidos, apresentamos das tabelas 6.20, 6.21, $6.22,6.23$ e 6.24 uma comparação entre a quantidade vendida de todos os produtos em todos os mercados e o respectivo ponto de equilíbrio. 
Tabela 6.20 - Ponto de Equilíbrio x Quantidade Vendida dos Produtos da UEN-1 nos Respectivos Mercados

\begin{tabular}{|c|c|c|c|c|c|c|}
\hline \multicolumn{2}{|c|}{ Análise por Produto } & $\begin{array}{c}\text { Mercado } \\
1\end{array}$ & $\begin{array}{c}\text { Mercado } \\
2\end{array}$ & $\begin{array}{c}\text { Mercado } \\
\mathbf{3}\end{array}$ & $\begin{array}{c}\text { Mercado } \\
4\end{array}$ & $\begin{array}{c}\text { Mercado } \\
5\end{array}$ \\
\hline \multirow{2}{*}{ Produto 1} & Qtde vendida & 60 & 58 & 53 & 53 & 48 \\
\hline & Ponto de Equilíbrio & 29 & 37 & 43 & 53 & 62 \\
\hline \multirow{2}{*}{ Produto 2} & Qtde vendida & 99 & 89 & 86 & 79 & -- \\
\hline & Ponto de Equilíbrio & 53 & 54 & 55 & 57 & -- \\
\hline \multirow{2}{*}{ Produto 3} & Qtde vendida & 25 & 14 & -- & -- & -- \\
\hline & Ponto de Equilíbrio & 30 & 41 & -- & -- & -- \\
\hline \multirow{2}{*}{ Produto 4} & Qtde vendida & 14 & 10 & -- & -- & -- \\
\hline & Ponto de Equilíbrio & 29 & 33 & -- & -- & -- \\
\hline \multirow{2}{*}{ Produto 5} & Qtde vendida & 199 & 198 & 194 & 195 & 197 \\
\hline & Ponto de Equilíbrio & 70 & 72 & 73 & 74 & 75 \\
\hline \multirow{2}{*}{ Produto 6} & Qtde vendida & 90 & 83 & 81 & 79 & 70 \\
\hline & Ponto de Equilíbrio & 37 & 39 & 43 & 46 & 48 \\
\hline \multirow{2}{*}{ Produto 7} & Qtde vendida & 140 & 118 & 93 & -- & -- \\
\hline & Ponto de Equilíbrio & 94 & 76 & 78 & -- & -- \\
\hline \multirow{2}{*}{ Produto 8} & Qtde vendida & 46 & 38 & 23 & 19 & -- \\
\hline & Ponto de Equilíbrio & 22 & 26 & 29 & 32 & -- \\
\hline \multirow{2}{*}{ Produto 9} & Qtde vendida & 44 & 38 & 30 & -- & -- \\
\hline & Ponto de Equilíbrio & 41 & 48 & 58 & -- & -- \\
\hline \multirow{2}{*}{ Produto 10} & Qtde vendida & 41 & 33 & 24 & 13 & -- \\
\hline & Ponto de Equilíbrio & 20 & 25 & 31 & 33 & -- \\
\hline \multirow{2}{*}{ Produto 11} & Qtde vendida & 96 & 85 & 79 & 62 & -- \\
\hline & Ponto de Equilíbrio & 51 & 55 & 59 & 61 & -- \\
\hline \multirow{2}{*}{ Produto 12} & Qtde vendida & 25 & 25 & -- & -- & -- \\
\hline & Ponto de Equilíbrio & $\mathbf{0}$ & $\mathbf{0}$ & -- & -- & -- \\
\hline
\end{tabular}

Então, o Ponto de Equilíbrio do Produto-1, da UEN-1 no Mercado-1 foi calculado a partir da Equação-92 (página 110) e os dados para equação na Tabela-6.1 (página 133). O cálculo da Margem Bruta de Contribuição unitária é calculada pela Equação-18, conforme apresentado abaixo:

$$
\begin{aligned}
& M B C u_{11}=1.140,00-84,36-10,15=1.045,49 \\
& Q e_{\left(P_{1} / U E N_{1}\right)}=\frac{C D F_{11}}{M B C u_{11}}=\frac{30.234,00}{1.045,49}=28,92 \cong 29
\end{aligned}
$$

Como o cálculo de todos os indicadores apresentados nas tabelas 6.20 a 6.24 seguem o mesmo princípio, serão apresentados somente os resultados para análise. 
Tabela 6.21 - Ponto de Equilíbrio x Quantidade Vendida dos Produtos da UEN-2 nos Respectivos Mercados

\begin{tabular}{|c|c|c|c|c|c|c|}
\hline \multicolumn{2}{|c|}{ Análise por Produto } & $\begin{array}{c}\text { Mercado } \\
1 \\
\end{array}$ & $\begin{array}{c}\text { Mercado } \\
2 \\
\end{array}$ & $\begin{array}{c}\text { Mercado } \\
3 \\
\end{array}$ & $\begin{array}{c}\text { Mercado } \\
4 \\
\end{array}$ & $\begin{array}{c}\text { Mercado } \\
5 \\
\end{array}$ \\
\hline \multirow{2}{*}{ Produto 1} & Qtde vendida & 428 & 346 & 335 & 275 & -- \\
\hline & Ponto de Equilíbrio & 196 & 166 & 151 & 141 & -- \\
\hline \multirow{2}{*}{ Produto 2} & Qtde vendida & 0 & 25 & 14 & 23 & -- \\
\hline & Ponto de Equilíbrio & $\mathbf{0}$ & 18 & 17 & 19 & -- \\
\hline \multirow{2}{*}{ Produto 3} & Qtde vendida & 85 & 67 & 49 & 38 & -- \\
\hline & Ponto de Equilíbrio & 40 & 40 & 25 & 24 & -- \\
\hline \multirow{2}{*}{ Produto 4} & Qtde vendida & 77 & 69 & 43 & 48 & -- \\
\hline & Ponto de Equilíbrio & 39 & 35 & 25 & 24 & -- \\
\hline \multirow{2}{*}{ Produto 5} & Qtde vendida & 50 & 48 & 45 & 46 & -- \\
\hline & Ponto de Equilíbrio & 26 & 21 & 23 & 23 & -- \\
\hline \multirow{2}{*}{ Produto 6} & Qtde vendida & 97 & 86 & 69 & 67 & -- \\
\hline & Ponto de Equilíbrio & 40 & 39 & 36 & 36 & -- \\
\hline \multirow{2}{*}{ Produto 7} & Qtde vendida & 359 & 251 & 210 & 176 & -- \\
\hline & Ponto de Equilíbrio & 142 & 121 & 104 & 100 & -- \\
\hline \multirow{2}{*}{ Produto 8} & Qtde vendida & 0 & 0 & 28 & 17 & -- \\
\hline & Ponto de Equilíbrio & $\mathbf{0}$ & $\mathbf{0}$ & 24 & 25 & -- \\
\hline \multirow{2}{*}{ Produto 9} & Qtde vendida & 30 & 29 & -- & -- & -- \\
\hline & Ponto de Equilíbrio & $\mathbf{0}$ & $\mathbf{0}$ & -- & -- & -- \\
\hline
\end{tabular}

Tabela 6.22 - Ponto de Equilíbrio x Quantidade Vendida dos Produtos da UEN-3

nos Respectivos Mercados

\begin{tabular}{|l|l|c|c|c|c|c|}
\hline \multicolumn{2}{|c|}{ Análise por Produto } & $\begin{array}{c}\text { Mercado } \\
\mathbf{1}\end{array}$ & $\begin{array}{c}\text { Mercado } \\
\mathbf{2}\end{array}$ & $\begin{array}{c}\text { Mercado } \\
\mathbf{3}\end{array}$ & $\begin{array}{c}\text { Mercado } \\
\mathbf{4}\end{array}$ & $\begin{array}{c}\text { Mercado } \\
\mathbf{5}\end{array}$ \\
\hline \multirow{2}{*}{ Produto 1 } & Qtde vendida & 87 & 58 & 47 & -- & - \\
\cline { 2 - 7 } & Ponto de Equilíbrio & $\mathbf{3 2}$ & $\mathbf{2 6}$ & $\mathbf{2 3}$ & -- & -- \\
\hline \multirow{2}{*}{ Produto 2 } & Qtde vendida & 48 & 42 & 36 & -- & -- \\
\cline { 2 - 7 } & Ponto de Equilíbrio & $\mathbf{2 6}$ & $\mathbf{2 6}$ & $\mathbf{2 8}$ & -- & -- \\
\hline \multirow{2}{*}{ Produto 3 } & Qtde vendida & 50 & 45 & 41 & -- & -- \\
\cline { 2 - 7 } & Ponto de Equilíbrio & $\mathbf{2 5}$ & $\mathbf{2 2}$ & $\mathbf{2 2}$ & -- & -- \\
\hline
\end{tabular}


Tabela 6.23 - Ponto de Equilíbrio x Quantidade Vendida dos Produtos da UEN-4 nos Respectivos Mercados

\begin{tabular}{|c|c|c|c|c|c|c|}
\hline \multicolumn{2}{|c|}{ Análise por Produto } & $\begin{array}{c}\text { Mercado } \\
1\end{array}$ & $\begin{array}{c}\text { Mercado } \\
2\end{array}$ & $\begin{array}{c}\text { Mercado } \\
3\end{array}$ & $\begin{array}{c}\text { Mercado } \\
4\end{array}$ & $\begin{array}{c}\text { Mercado } \\
5\end{array}$ \\
\hline \multirow{2}{*}{ Produto 1} & Qtde vendida & 46 & 35 & 28 & 19 & 8 \\
\hline & Ponto de Equilíbrio & 13 & 12 & 13 & 13 & 15 \\
\hline \multirow{2}{*}{ Produto 2} & Qtde vendida & 50 & 47 & 38 & 17 & -- \\
\hline & Ponto de Equilíbrio & 18 & 18 & 20 & 19 & -- \\
\hline \multirow{2}{*}{ Produto 3} & Qtde vendida & 168 & 139 & 144 & 108 & -- \\
\hline & Ponto de Equilíbrio & 100 & 87 & 74 & 63 & -- \\
\hline \multirow{2}{*}{ Produto 4} & Qtde vendida & 45 & 32 & 22 & 18 & 11 \\
\hline & Ponto de Equilíbrio & 12 & 18 & 18 & 16 & 16 \\
\hline \multirow{2}{*}{ Produto 5} & Qtde vendida & 50 & 38 & 25 & 23 & 15 \\
\hline & Ponto de Equilíbrio & 13 & 17 & 19 & 18 & 18 \\
\hline \multirow{2}{*}{ Produto 6} & Qtde vendida & 38 & 25 & 20 & 18 & 7 \\
\hline & Ponto de Equilíbrio & 12 & 16 & 16 & 17 & 18 \\
\hline \multirow{2}{*}{ Produto 7} & Qtde vendida & 0 & 34 & 23 & 8 & -- \\
\hline & Ponto de Equilíbrio & $\mathbf{0}$ & 27 & 26 & 29 & -- \\
\hline \multirow{2}{*}{ Produto 8} & Qtde vendida & 47 & 37 & 28 & 22 & -- \\
\hline & Ponto de Equilíbrio & 22 & 24 & 25 & 26 & -- \\
\hline \multirow{2}{*}{ Produto 9} & Qtde vendida & 46 & 33 & 19 & 13 & -- \\
\hline & Ponto de Equilíbrio & 17 & 17 & 17 & 18 & -- \\
\hline
\end{tabular}

Tabela 6.24 - Ponto de Equilíbrio x Quantidade Vendida dos Produtos da UEN-5 nos Respectivos Mercados

\begin{tabular}{|l|l|c|c|c|c|c|}
\hline \multicolumn{2}{|c|}{ Análise por Produto } & $\begin{array}{c}\text { Mercado } \\
\mathbf{1}\end{array}$ & $\begin{array}{c}\text { Mercado } \\
\mathbf{2}\end{array}$ & $\begin{array}{c}\text { Mercado } \\
\mathbf{3}\end{array}$ & $\begin{array}{c}\text { Mercado } \\
\mathbf{4}\end{array}$ & $\begin{array}{c}\text { Mercado } \\
\mathbf{5}\end{array}$ \\
\hline \multirow{2}{*}{ Produto 1 } & Qtde vendida & 87 & 68 & 45 & 33 & -- \\
\cline { 2 - 7 } & Ponto de Equilíbrio & $\mathbf{4 4}$ & $\mathbf{4 8}$ & $\mathbf{2 6}$ & $\mathbf{2 5}$ & -- \\
\hline \multirow{2}{*}{ Produto 2 } & Qtde vendida & 92 & 75 & 33 & 35 & -- \\
\cline { 2 - 8 } & Ponto de Equilíbrio & $\mathbf{4 2}$ & $\mathbf{4 3}$ & $\mathbf{2 3}$ & $\mathbf{2 9}$ & -- \\
\hline \multirow{2}{*}{ Produto 3 } & Qtde vendida & 89 & 71 & 47 & 25 & -- \\
\cline { 2 - 8 } & Ponto de Equilíbrio & $\mathbf{4 1}$ & $\mathbf{4 3}$ & $\mathbf{2 3}$ & $\mathbf{2 2}$ & -- \\
\hline \multirow{2}{*}{ Produto 4 } & Qtde vendida & 97 & 78 & 72 & 45 & -- \\
\cline { 2 - 8 } & Ponto de Equilíbrio & $\mathbf{4 1}$ & $\mathbf{4 3}$ & $\mathbf{4 1}$ & $\mathbf{2 3}$ & -- \\
\hline \multirow{2}{*}{ Produto 5 } & Qtde vendida & 30 & 30 & -- & -- & -- \\
\cline { 2 - 8 } & Ponto de Equilíbrio & $\mathbf{0}$ & $\mathbf{0}$ & -- & -- & -- \\
\hline
\end{tabular}

Utilizando a Equação-95 (página 110), pode se calcular o Ponto de Equilíbrio Global para todas as UENs a partir da Margem de Segurança. Cabe ressaltar as 
restrições de utilização desse indicador discutidas no item 5.2.4 dessa tese. Como dito, não existe apenas um ponto de equilíbrio, e sim infinitos pontos factíveis e que o resultado aqui apresentado é dependente do mix atual.

$$
Q e_{U E N-k}=Q_{\text {Total }} \cdot\left(1-M S_{U E N-k}\right)
$$

Então, para o cálculo do Ponto de Equilíbrio da UEN-1, a quantidade total de alunos deve ser extraída da Tabela-6.1 (página 133) e a Margem de Segurança da Tabela 6.19 (página 157), ficando a equação acima da seguinte forma:

$$
\begin{aligned}
& Q e_{U E N-1}=(60+58+53+53+48+99+89+\ldots+62+25+25) \cdot(1-4 \%) \\
& Q e_{U E N-1}=3.146 \cdot(0,96)=3.020 \text { alunos }
\end{aligned}
$$

Tabela 6.25 - Ponto de Equilíbrio das UEN's

\begin{tabular}{|c|c|c|c|}
\hline UENs & $\mathbf{Q}_{\text {total }}$ & MS & $\begin{array}{c}\text { Ponto de } \\
\text { Equilíbrio }\end{array}$ \\
\hline UEN 1 & 3.146 & $4,00 \%$ & 3.020 \\
\hline UEN 2 & 3.530 & $27,75 \%$ & 2.550 \\
\hline UEN 3 & 454 & $0,90 \%$ & 450 \\
\hline UEN 4 & 1.544 & $6,30 \%$ & 1.447 \\
\hline UEN 5 & 1.052 & $-8,96 \%$ & 1.146 \\
\hline
\end{tabular}

Pode-se perceber na tabela acima que quanto maior a Margem de Segurança maior a distância entre a quantidade vendida e a quantidade de equilíbrio, reforçando toda a teoria discutida. 


\section{CONCLUSÃO}

A primeira hipótese foi verificada como verdadeira, pois foi possível aplicar o modelo matemático no sistema administrativo proposto, criando condições do desenvolvimento do modelo econômico esquemático.

Só é possível aplicar a metodologia proposta se as UENs das empresas estiverem de acordo com a definição básica de Unidade Estratégica de Negócios apresentada pela Gerenal Eletric: "uma unidade de negócio é uma divisão, linha de produtos ou outro centro de lucro de uma empresa que produz e comercializa um conjunto bem definido de produtos e/ou serviços correlatos, serve um conjunto claramente definido de clientes, numa área geográfica razoavelmente bem delimitada, competindo com um conjunto bem definido de concorrentes."

Nesse sentido, as premissas que podem ser utilizadas para o delineamento das UENs também devem ser verificadas, como mostrado abaixo:

- estar relacionada a um segmento específico;

- ter vantagem competitiva real e efetiva;

- ter melhor adequação geográfica;

- ter uma única missão ou negócio, independente de outras UENs (ou, preferencialmente, estar na missão do grupo empresarial);

- ter um conjunto de concorrentes claramente definidos;

- competir em mercados específicos;

- ser capaz de desenvolver um planejamento integrado, independentemente de outras UENs;

- ter um responsável pelo planejamento e resultados das UENs;

- ser capaz de administrar recursos;

- operar em um único segmento de mercado com estratégia concentrada;

- parecer e agir como um negócio independente.

A segunda hipótese também foi verificada como verdadeira, pois foi possível desenvolver equações para os indicadores propostos a partir do modelo econômico formulado. 
Aplicação através do estudo de caso valida a terceira hipótese, pois é possível aplicar a metodologia em empresas das mais diversas áreas econômicas que se organizam na estrutura do tipo Sede Administrativa e Várias Unidades de Negócios, sendo que as unidades podem estar ou não geograficamente dispersas.

A aplicação da metodologia foi muito importante, pois foi realizado uma revisão cíclica entre teoria, dados e teoria, gerando alteração na estrutura da modelagem matemática, prevendo a possibilidade de mais de um produto compartilhar custos e despesas fixas tanto no nível 1 como no nível 2.

O estudo adequado das variações de custos fixos e variáveis, preços e do volume de vendas pode ser feito por meio da análise da alavancagem operacional. Os subsídios fornecidos pela análise da alavancagem operacional atendem a muitas necessidades do estudo econômico de uma atividade ou produto. Em especial, a sensibilidade dos resultados a variações de vendas e a indicação de priodirades dos esforços de vendas entre os produtos.

Outras aplicações importantes referem-se ao subsídio para negociações envolvendo reduções de preços ou concessão de outras vantagens para obtenção de aumento de vendas. Pode auxiliar também a provisão de elementos adicionais para a tomada de decisões em investimentos.

O ponto de equilíbrio pode ser estudado para um produto com relação aos seus custos fixos próprios, para um produto único de uma empresa ou de uma fábrica da empresa, considerando todos os seus custos e despesas fixas, ou para atividades parciais ou totais de uma empresa envolvendo mais de um produto. Neste último caso, a condição do ponto de equilíbrio passa a depender de hipóteses assumidas sobre a participação relativa dos vários produtos. Essas hipóteses podem ser dispensadas quando existe uma correlação entre as demandas dos produtos, como no caso de produtos complementares cuja proporção de vendas seja bastante estável, ou quando existe uma unidade de medida que resuma satisfatoriamente as proporções de participação dos produtos. 
Para a aplicação da metodologia o sistema orçamentário e contábil das empresas devem ser adequados de modo a gerar as variáveis independentes para o cálculo dos indicadores, se isso não for realizado, o levantamento de dados pode inviabilizar a implantação e a manutenção das informações do sistema.

Outro ponto crítico de aplicação da metodologia acontece quando a empresa está operando no limite de sua capacidade produtiva. Nesse caso não faz sentido analisar o aumento de lucro a partir do aumento da produção, pois a capacidade produtiva já está no limite e não poderá atender a uma nova demanda, ou gerará custos extras, alterando todo o sistema

Caso isso ocorra, uma possibilidade de análise é escolher qual mix de produção gerará maior lucratividade para a UEN ou sistema administrativo. A pesquisa operacional pode ser um instrumento de auxílio a tomada de decisão, mas esse estudo não faz parte dessa tese, ficando como sugestão para continuação desse trabalho.

Outra sugestão para continuação do trabalho é analisar o mix de vendas que irá otimizar os resultados dos Indicadores de Posição Econômica levando em consideração as restrições mercadológicas e técnicas do setor produtivo. 


\section{BIBLIOGRAFIA}

ANSOFF, H. Igor; McDonnell, Edward J. "Implantando a administração estratégica". $2^{a}$ ed., São Paulo: Atlas, 1993.

ATKINSON, Anthony A. et al. "Contabilidade Gerencial”. São Paulo: Atlas, 2000.

BORNIA, Antônio C. ANTÚNES JR., José Antônio Valle. “Considerações sobre a análise de custo-volume-lucro e o método das rotações". VII Encontro Nacional de Engenharia de Produção (1987).

BRUNSTEIN, Israel. "Alavancagem operacional e a criação de novas unidades industriais". VII Encontro Nacional de Engenharia de Produção - ENGEP (1987), Niterói/RJ.

BRUNSTEIN, Israel. "Notas de Aula".

BRUNSTEIN, Israel. "Economia de empresas: gestão econômica de negócios”. São Paulo: Atlas, 2005.

BRUNSTEIN, Israel. "Programação econômica na empresa: um modelo descritivo de referência”. VII Encontro Nacional de Engenharia de Produção - ENGEP (1987), Niterói/RJ.

BRUNSTEIN, Israel; MIORI, Celso. "Avaliação da normalidade da estrutura de custos fixos da empresa". Revista de Administração da FEA/USP, vol.23, No 2, abril/junho de 1988 .

BUZZEL, R. D.; GALE, B. T. "PIMS - O Impactos das Estratégias de Mercado no Resultado das Empresas”. São Paulo: Livraria Editora Pioneira, 1991.

CAPRA, Fritjof. "Ponto de Mutação”. 25a ed., São Paulo: Editora Cultrix, 2002.

CERTO, Samuel C.; PETER, J. Paulo. “Administração Estratégica: planejamento e implantação da estratégia”. São Paulo: Makron Books, 1993.

CHIAVENATO, Idalberto, "Introdução á teoria geral da administração". $4^{\mathrm{a}}$ ed., São Paulo: Malron Books, 1993. 
CHUNG, Kee H. "Cost-volume-profit analysis under uncertainty within the firm has production flexibility". Journal of Business Finance \& Acconting, 20(4), June 1993.

CORRAR, Luiz J. “Análise das reações custo-volume-lucro para multiprodutos em condições de incerteza". 1990, 470p. Tese de Doutorado. Departamento de Contabilidade e Atuária - Faculdade de Economia e Administração, Universidade de São Paulo. São Paulo, 1990.

COSTA, Magnus A. da. "Relações custo/volume/lucro para multiprodutos". Revista Administração de Empresas, Rio de janeiro, jan./mar.1988, pp.20-26.

COSTA, Reinaldo P. "Proposta de modelo e implementação de um sistema de apoio á decisão em pequenas indústrias”. 1998, 198p. Tese de Doutorado. Escola Politécnica, Universidade de São Paulo. São Paulo, 1998.

CURY, Antônio. "Organização e métodos: uma visão holística" - $7^{\mathrm{a}}$ ed. rev. e ampl. - São Paulo: Atlas, 2000.

EISENHARDT, Kathleen M. "Building Theories from Case Study Research". Academy of Management Review, 1989, vol. 14, № 4, p.532.

FILIPPINI, Robert. "Operations management research: some reflections on evolution, models and empirical studies in OM". International Journal of Opeations \& Production Management, volume 17, number 7, 1997.

FROOT, Kenneth; SCHARFSTEIN e STEIN. "A Framework For Risk Management". Harvard Business Review, pp.91 - 102 (novembro - dezembro 1994).

FUSCO, José P. A. “Considerações sobre gestão competitiva de preços”. 1993. 170p. Dissertação de Mestrado. Escola Politécnica, Universidade de São Paulo. São Paulo, 1993.

FUSCO, José P. A. "Gestão competitiva de preços uma visão integrada". 1996. 184p. Tese de Doutorado. Escola Politécnica, Universidade de São Paulo. São Paulo, 1996. 
GUTH, William D., "Handbook of Busines Strategy". Warren, Gorham \& Lamont, Massachusetts, 1985.

HILL, T., "Manufacturing Strategy: Text and Cases". - New York: Irwin, 1989.

HORNGREN, Charles T.; FOSTER, George. "Cost Accounting: a managerial emphasis". - $7^{\mathrm{a}}$ ed., Englewood Cliffs, New Jersey: Prentice Hall Internetional, 1991.

HORNGREN, Charles T.; SUNDEM, Gary L.; STRATTON, Willian O. “Contabilidade Gerencial”. 12a ed., São Paulo: Prentice Hall, 2004.

HORNGREN, Charles T.; DATAR, Srikant M.; FOSTER, George. "Contabilidade de Custos, V.1: uma abordagem gerencial”. $11^{\mathrm{a}}$ ed., São Paulo: Prentice Hall, 2004.

HORNGREN, Charles T.; DATAR, Srikant M.; FOSTER, George. "Contabilidade de Custos, V.2: uma abordagem gerencial". 11ª ed., São Paulo: Prentice Hall, 2004.

KAPLAN, Robert S.; NORTON, David P. “A estratégia em ação:balanced scorecard". Rio de Janeiro:Campus, 1997.

LAKATOS, Eva M.; MARCONI, Marina A. "Fundamentos da Metodologia Científica”. $5^{\text {a }}$ ed., São Paulo: Atlas, 2003.

LAZZARINI, Sérgio G. "Estudos de Caso: aplicabilidade e limitações do método para fins de pesquisa”. Revista Economia de Empresas, São Paulo, v.2, n.4, p.17, out/dez-1995.

LEONE, George S. G. "Custos: um enfoque administrativo". - 11'. Ed. Ver. e atual. - Rio de Janeiro: Editora da Fundação Getulio Vargas, 1995.

LOVEJOY, William S. "Integrated Operations: a proposal for operations management teaching and research". Journal of Production and Operations Management, vol. 7, $\mathrm{n}^{\circ}$ 2, Summer 1998, USA.

MAGEE, Bryan. “As Idéias de Popper”, tradução de Leonidas Hegenberg e Octanny Silveira da Mota, publicado na série Fontana Modern Masters, dirigida por

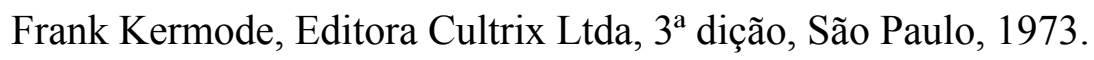


MARTINS, Eliseu. “Contabilidade de Custos”. 8ª ed., São Paulo: Atlas, 2001.

NAKANO, Davi Noboru; FLEURY, Afonso Carlos Corrêa. "Métodos de Pesquisa na Engenharia de Produção". Anais do XVI ENEGEPE, Piracicaba/SP, 1996.

OLIVEIRA, Djalma de Pinho Rebouças de. "Sistemas, organização e métodos: uma abordagem gerencial". 12 ed., São Paulo: Atlas, 2001.

POPPER, K. A Lógica da Pesquisa Científica. 2a Edição. São Paulo: Editora Cultrix, 1975.

PORTER, Michael. "Vantagem Competitiva: criando e sustentando um desempenho superior”. Rio de Janeiro: Campus, 1992.

RIEGE, A. M. "Validity and Reliability Tests in Case Study Research: literature review with "hands-on" applications for each research phase". Quality Market Research: An International Journal. Vol. 6, No. 2, pp. 75-86, 2003.

ROSA, E. B. Indicadores de Desempenho e Sistema ABC: O Uso de Indicadores para uma Gestão Eficaz do Custeio e das Atividades de Manutenção. Departamento de Engenharia de Produção da Escola Politécnica da Universidade de São Paulo, São Paulo, 2006, 509p. (Tese de Doutorado).

SANTOS, I. E. "Textos selecionados de métodos e técnicas de pesquisa científica". $4^{\mathrm{a}}$ ed., Ed. Impetus, Rio de Janeiro, 2003.

SCHWEITZER, Marcell; TROSSAMANN, Ernst; LAWSON, Gerald H. "Breakeven analyses: basic model, variants, extensions". New York: John Wiley \& Sons, 1992. Tradução do Original Alemão "Break-even analysen: grundmodell, varianten, erweitrungen", Stuttgart: C. E. Poeschel Verlag, 1986.

SHIRAISHI, Marcelo. "Sistema de custos e uma indústria de alimentos". 2003. 134p. Dissertação de Mestrado. Escola Politécnica, Universidade de São Paulo. São Paulo, 2003.

SLACK, N. D. C. "Vantagem Competitiva em Manufatura”. São Paulo: Atlas, 1993

THIOLLEN, Michel. "Metodologia da Pesquisa-ação". São Paulo: Cortez, $3^{a}$ ed, 1986 , 
TUCKER, S. A., "Profit planing decisions with the break-even system". Hampshire, England: Gower Publishing Company Limited, 1981.

TUFANO, Peter. "How Financial Engineering can Advance Corporate Strategy". Harvard Business Review, pp.135 - 146 (janeiro - fevereiro 1996).

VANDERBECK, Edward J.; NAGY, Charles F. “Contabilidade de Custos”. $11^{\mathrm{a}}$ ed. Brasil: Pioneira - 2001.

VERSCHUREN, Piet; DOOREWAARD, Hans. "Designing a Research Project", Publisher Lemma - Utrecht, 1999.

VOSS, C; TSIRITSIS, N; FROHLICH, M. "Case Research in Operations Management". International Journal of Operations \& Production Management. Vol. 22, No. 2, pp. 195-212, 2002.

YIN, R. K. "Case study research: design and methods". Sage, Newbury PARK, 166 p. 1994.

WRIGHT, Peter L.; KROLL, Mark J.; PARNELL, John. - “Administração estratégica: conceitos” - São Paulo: Atlas, 2000. 